\title{
A DISCRICIONARIEDADE NO PROCESSO DECISÓRIO DA AGÊNCIA NACIONAL DE TELECOMUNICAÇÕES -
} ANATEL

\author{
Dissertação de Mestrado apresentada ao \\ Departamento de Direito do Estado da Faculdade \\ de Direito da Universidade de São Paulo para \\ obtenção do título de Mestre em Direito. \\ Orientação: Prof. Dr. Floriano de Azevedo \\ Marques Neto.
}

FACULDADE DE DIREITO DA UNIVERDIDADE DE SÃO PAULO

SÃO PAULO

2012 


\section{FOLHA DE APROVAÇÃO}

Milene Louise Renée Coscione

A Discricionariedade no Processo Decisório da Agência Nacional de Telecomunicações - ANATEL

Aprovada em:

Prof. Dr.

Instituição:

Assinatura:

Prof. Dr.

Instituição:

Assinatura:

Prof. Dr.

Instituição:

Assinatura: 
Ao meu pai querido, Luiz Francisco Coscione, expressão máxima do meu amor.

Ao meu marido, Enrique Campos, prova maior de que alma gêmea existe. 


\section{AGRADECIMENTOS}

Agradeço, ao meu pai querido, Luiz Francisco Coscione, meu grande amigo. Não existem palavras que consigam expressar minha gratidão a você por ter participado tão de perto de todos os momentos da minha vida e, especialmente, da minha formação jurídica. Muito obrigada por estar sempre ao meu lado e por me incentivar em todos os momentos.

Agradeço, igualmente, a minha mãe, Julia Roseli Furbetta Coscione, por ser a minha força e refúgio. Muito obrigada por compartilhar comigo tanto de nossas vidas.

Agradeço às minhas irmãs: Aline Renée Coscione, exemplo de inteligência, que me mostrou que tudo é possível quando nos dedicamos aos estudos e nos comprometemos com nossos objetivos; Denise Renée Coscione, exemplo de força, que me ensina, a cada dia, que podemos enfrentar qualquer obstáculo e que olhar para o futuro é nossa melhor opção; e Cibele Renée Coscione, minha irmã gêmea, exemplo de doçura, que me demonstra, em todas as oportunidades, a importância da nossa família. Irmãs, sinto muitas saudades de vocês.

Agradeço à minha avó, Jamile Curi Furbetta, por tantas lembranças divertidas e perfumadas. Obrigada avó querida.

Agradeço ao meu marido, Enrique Campos, por todo amor, amizade, companheirismo e paciência. Obrigada, também, pelo tempo que me deu e por ter feito deste trabalho um objetivo nosso. Obrigada, ainda, por tornar todos os meus dias muito melhores. Não tenho dúvida de que sem você tudo seria quase impossível.

Agradeço ao Luke por ter estado ao meu lado horas a fio durante este trabalho e por ter me ensinado tanto em tão pouco tempo.

Agradeço às minhas queridas amigas Denise Junqueira e Renata Navarro por nunca terem desistido de mim, mesmo diante da minha constante ausência. Obrigada meninas.

Agradeço à Eliane Cristina Bozo, excelente secretária e fiel amiga, pela ajuda imprescindível nos momentos mais críticos. Muito obrigada. 
Agradeço à Fernanda Fini que me mostrou que é possível manter um alto nível de profissionalismo e ao mesmo tempo cultivar uma amizade verdadeira. Obrigada amiga.

Agradeço à Clarissa Sampaio e Ana Lúcia Ikenaga pela amizade e pela preciosa ajuda nos minutos finais deste trabalho.

Um agradecimento especial ao Professor Floriano de Azevedo Marques, meu orientador, exemplo de advogado e acadêmico, por tornar tudo possível. Ainda hoje sou surpreendida com o seu brilhantismo. Muito obrigada.

Agradeço fraternalmente ao Professor Carlos Ari Sundfeld, por ter me iniciado no Direito Administrativo e por ter me ensinado a pesquisar e a pensar o Direito; à querida amiga Roberta Sundfeld que me acolheu com tanto carinho todos esses anos; e à Sociedade Brasileira de Direito Público - SBDP, onde tive o privilégio de participar da primeira e da segunda turma da Escola de Formação, nos anos de 1998 e 1999. Ter feito parte deste projeto sensacional mudou minha vida para sempre. Muito obrigada. 


\section{NOTAS PROPEDÊUTICAS}

As obras e artigos citados apenas por interessarem a um aspecto específico deste trabalho podem não ter sido incluídos na bibliografia final, na qual estão presentes as obras e artigos que apresentam conexão mais ampla com o tema desenvolvido. Estas, por sua vez, podem, eventualmente, não ter sido objeto de referência direta ao longo do texto, haja vista a sua contribuição indireta para esta dissertação.

Com relação às abreviaturas, deixou-se de apresentar um glossário porque estas foram utilizadas de forma a não gerar dúvidas quanto ao seu significado. 


\section{SUMÁRIO}

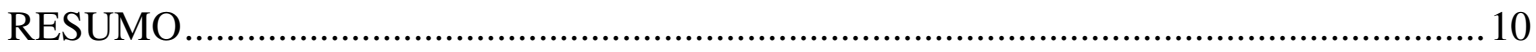

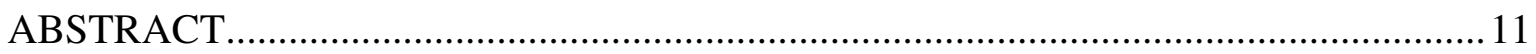

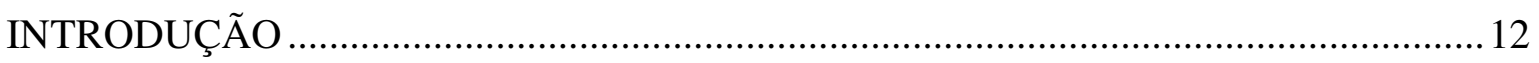

PARTE I - DISCRICIONARIEDADE - DO CLÁSSICO AO CONTEMPORÂNEO....... 16

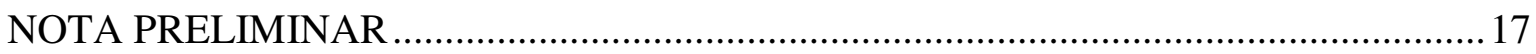

CAPÍTULO I - A DISCRICIONARIEDADE DA ADMINISTRAÇÃO PÚBLICA EM

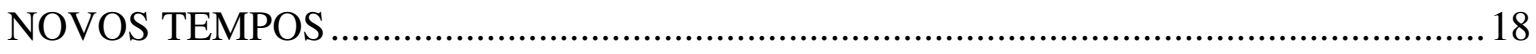

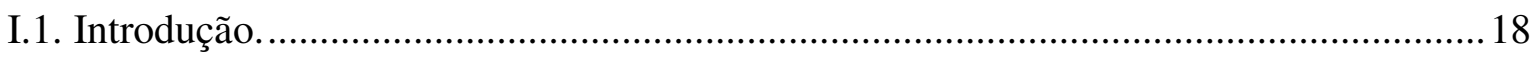

I.2. A Concepção Clássica de Discricionariedade Administrativa. .................................. 19

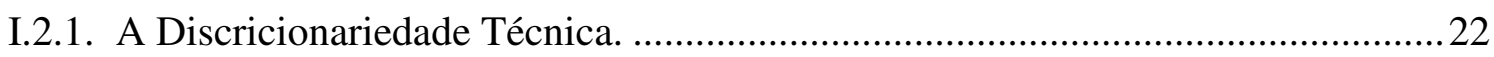

I.3. A Discricionariedade no Estado Contemporâneo........................................................26

I.3.1. A Discricionariedade em face da Pluralidade de Interesses Legítimos

Contrapostos e a sua Mediação Ativa pelo Regulador. ..................................................2

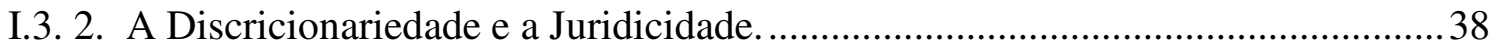

I.3. 3. A Discricionariedade e a Policentrismo Estatal. .................................................. 44

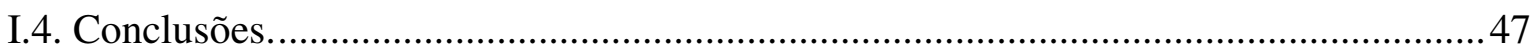

PARTE II - DISCRICIONARIEDADE E ARBITRARIEDADE .......................................48

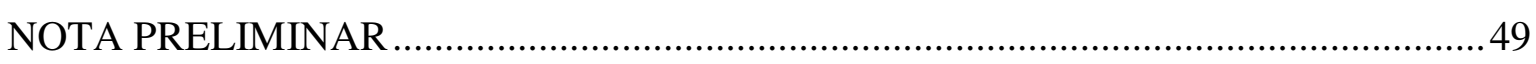

CAPÍTULO II - DISCRICIONARIEDADE versus ARBITRARIEDADE .........................50

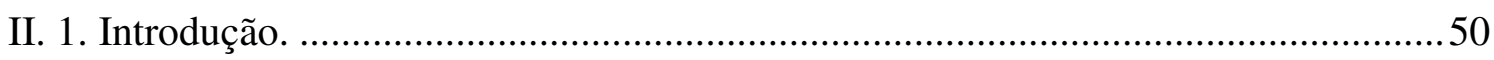

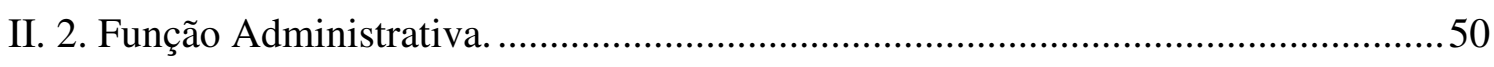

II. 3. A Arbitrariedade da Administração Pública. .........................................................57

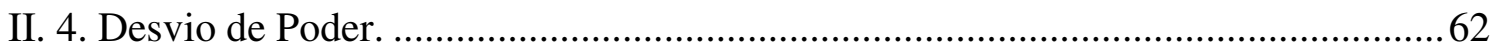

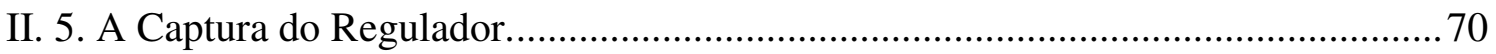

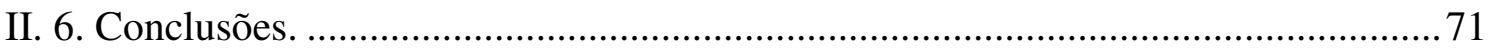


CAPÍTULO III - A DISCRICIONARIEDADE DA AGÊNCIA REGULADORA NACIONAL DE TELECOMUNICAÇÕES - ANATEL NOS PROCESSOS DECISÓRIOS SOBRE TRANSFERÊNCIA DE CONTROLE DE OPERADORAS DE SERVIÇOS DE TELECOMUNICAÇÕES: ESTUDO DE CASOS ......................................................... 73

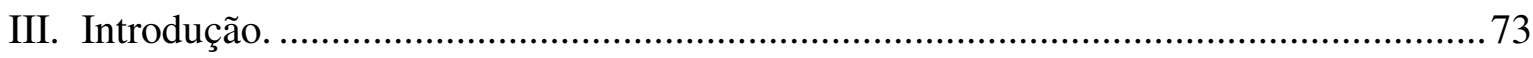

III. I. 1. A Agência Reguladora Nacional de Telecomunicações - ANATEL. ...................74

III. I. 1. 1. Origem e Competências. ........................................................................ 74

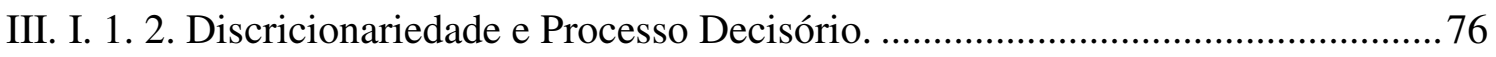

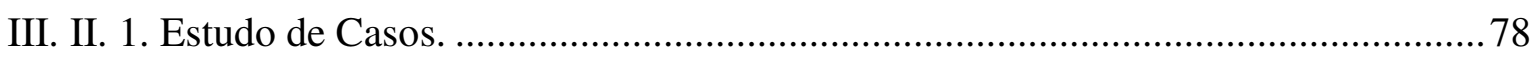

III. II. 2. Metodologia de Pesquisa dos Precedentes da ANATEL..................................... 79

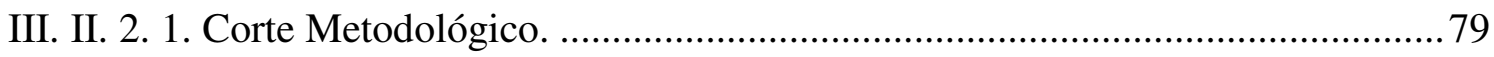

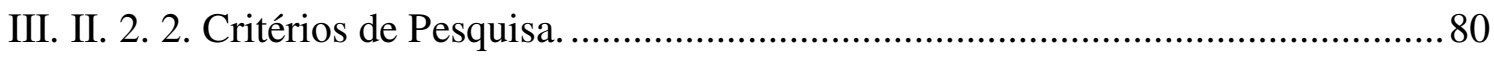

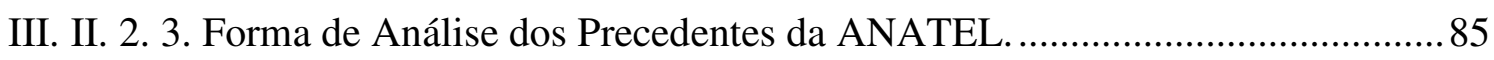

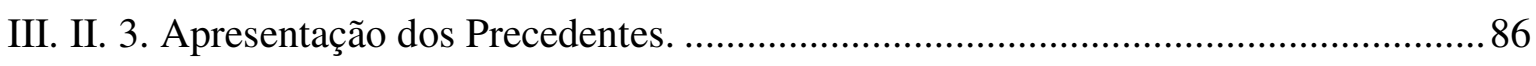

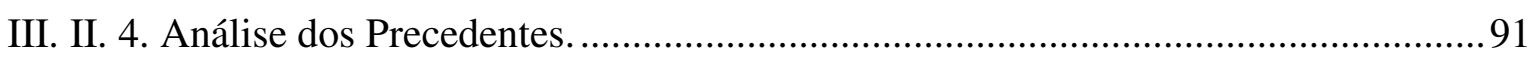

III. II. 4. 1. Os Critérios de Decisão da ANATEL....................................................... 92

III. II. 4. 2. Os Condicionamentos e Contrapartidas Impostos pela ANATEL............... 102

III. II. 5. Análise do Exercício da Discricionariedade nas Decisões da ANATEL............. 133

III. II. 5. 1. Critérios de Análise da ANATEL versus Decisões Discricionárias da

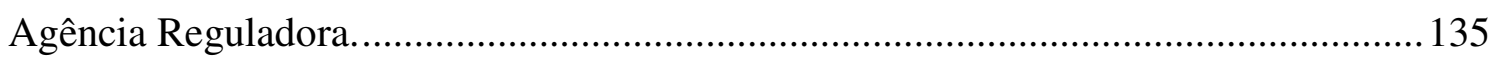

III. II. 5. 2. A Cronologia das Decisões da Agência Reguladora.................................. 139

III. II. 5. 3. A Identificação e o Sopesamento dos Interesses Envolvidos nos Precedentes

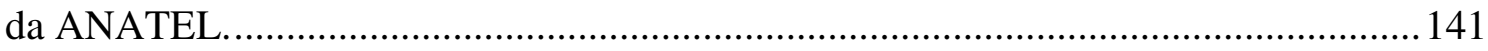

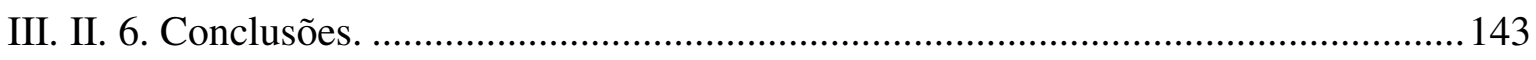

PARTE III - EM BUSCA DA DETERMINAÇÃO DOS MOTIVOS DAS DECISÕES

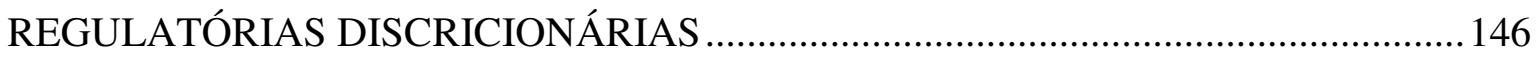

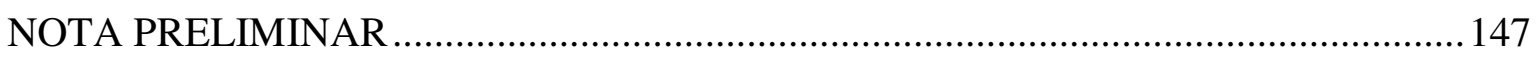

CAPÍTULO IV - O CONTROLE JUDICIAL DAS DECISÕES REGULATÓRIAS

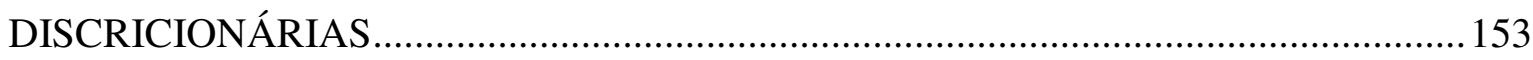


IV. 1. Introdução.

IV. 2. O Estado de Direito.

IV. 3. A Inafastabilidade do Controle dos Atos Administrativos pelo Poder Judiciário.

IV. 4. O Mérito do Ato Administrativo.

IV.4.1. Mérito versus Legalidade dos Atos Administrativos Discricionários. 163

IV. 5. O Controle Judicial dos Atos Administrativos. 165

IV.5.1. A Substitutividade das Decisões Administrativas Discricionárias. 180

IV. 5. 2. O Controle das Decisões Regulatórias Discricionárias. 185

IV. 6. Conclusões 192

CAPÍTULO V - PARÂMETROS DE CONTROLE DAS DECISÕES DISCRICIONÁRIAS DA ANATEL 196

V. 1. Introdução. 196

V. 2. A Importância de se Estabelecer Parâmetros Concretos e Objetivos para a Atuação Regulatória Discricionária. Segurança Jurídica: Estabilidade e Previsibilidade. 198

V. 3. A Racionalidade dos Juízos de Ponderação do Regulador. 202

V. 4. O Pressuposto Agir Administrativo Adstrito ao Processo. 206

V. 5. Parâmetros de Aferição Casuística da Melhor Solução Juridicamente Possível. .216 V. 5. 1. A Vinculação aos Precedentes da ANATEL. 218

V. 5. 2. A Motivação Positiva e Negativa de Todos os Atos do Processo Decisório.

V. 5. 3. A Transparência do Processo Decisório. 238

V. 5. 4. A Efetividade da Decisão Regulatória Discricionária e o Prognóstico da sua Efetividade.

V. 6. Conclusões. 267

CONSIDERAÇÕES FINAIS 269

BIBLIOGRAFIA FINAL 273 


\section{RESUMO}

Esta dissertação de mestrado se propõe a analisar a discricionariedade nos processos decisórios das Agências Reguladoras e, em especial, da ANATEL, em um contexto de transformações na relação Estado - sociedade civil, no qual se evidencia espaço alargado de atuação estatal na mediação ativa de interesses legítimos. A ampliação dos bordes da discricionariedade administrativa propicia, na mesma proporção, o aumento do risco de cometimento de arbitrariedades pelas autoridades públicas e, especificamente, pelo regulador setorial. O regulado apresenta-se, assim, em condição de hiposuficiência com relação ao regulador. A casuística da ANATEL evidencia a inexistência de parâmetros concretos e objetivos que possibilitem o acompanhamento do processo formativo de suas decisões regulatórias discricionárias e a sua eventual confrontação pelos interessados e pelos órgãos de fiscalização, especialmente, pelo Poder Judiciário. Temos a convicção de que a discricionariedade nos processos decisórios declaratórios das Agências Reguladoras, no âmbito do exercício da mediação ativa de interesses legítimos contrapostos, não é incondicionada e ilimitada, está subsumida à ordem jurídica. Da mesma forma, acreditamos que as escolhas administrativas (e regulatórias) devem ser previsíveis e passíveis de amplo e objetivo controle pelos interessados e pelo Poder Judiciário. Estas afirmações, entretanto, quando provadas no âmbito do controle judicial das decisões regulatórias discricionárias não podem ser aferidas, caso a caso. Isso porque, ainda, se propugna por um núcleo do ato administrativo insindicável (mérito) e pela preponderância, indistintamente, das decisões das Agências Reguladoras com relação às decisões judiciais, em razão de sua tecnicidade. A definição, pois, de parâmetros concretos e objetivos para o acompanhamento da formação das decisões regulatórias discricionárias e para a sua confrontação judicial contribuem para identificar e inibir eventuais arbitrariedades do regulador e fortalecer a atuação da ANATEL e o seu controle pelos interessados e pelo Poder Judiciário. Com esta finalidade, ao final deste trabalho, propomos os seguintes parâmetros objetivos: (i) a vinculação aos precedentes da ANATEL; (ii) a motivação positiva e negativa de todos os atos do processo decisório; (iii) a transparência do processo decisório; e (iv) a efetividade e o prognóstico da efetividade das decisões regulatórias discricionárias.

Palavras chave: Discricionariedade - Arbitrariedade - Controle - ANATEL - Parâmetros 


\section{ABSTRACT}

This essay intends to analyze the discretionary in the decision making processes of regulatory agencies and, in particular, ANATEL, in a context of changes in the relationship between state and civil society, in which it shows enlarged area of state action in the active mediation of interests legitimate. The expansion of the administrative discretion edges provides, in the same proportion, the increased the risk of committing arbitrary acts by public authorities and, specifically, the regulator. The regulated is presented thus in a weakness position with respect to the regulator. The precedents of ANATEL demonstrates that do not exist concretes and objectives parameters that allow the monitoring of the formation process of their discretionary regulatory decisions and their possible confrontation by the parties and the control entities, especially by the judiciary. We are convinced that the discretion in decision making processes of regulatory agencies, in the exercise of active mediation of legitimate interests opposed, is not unconditional and unlimited, is under law. Likewise, we believe that the administrative choices (and regulatory) should be predictable and subject to extensive and objective control by the parties and the judiciary. These statements, however, when tested in the context of judicial review of discretionary regulatory decisions can not be measured in each case. This is because, part of the administrative doctrine argue that remains a core of the administrative act which is not under control by the judiciary and the preponderance, indistinctly, the decisions of regulatory agencies with respect to judicial decisions, due to your technicality. The definition, therefore, concrete and objective parameters for monitoring the formation of discretionary regulatory decisions and for their judicial confrontation help to identify and inhibit possible arbitrariness of the regulator and strengthen the activities of ANATEL and its control by the parties and the judiciary. To this end, we propose the following objective parameters: (i) the binding precedents of ANATEL (ii) positive and negative motivation of all acts of decision making, (iii) the transparency of decision making; and (iv) the effectiveness and prognosis of the effectiveness of discretionary regulatory decisions.

Keywords: Discretion - Arbitrariness - Control - ANATEL - Parameters 


\section{INTRODUÇÃO}

As últimas décadas foram marcadas por profundas transformações na relação entre Estado e sociedade civil. Institutos basilares do Direito Administrativo (paradigmas $^{2}$ ), de conformação oitocentista, tem sido colocados em cheque diante de uma realidade mais complexa e altamente dinâmica que reclama uma ordenação renovada. ${ }^{3}$

Algumas dessas transformações já se encontram refletidas no Direito Administrativo contemporâneo ${ }^{4}$, outras são objeto de pesquisas e estudos jurídicos que buscam identificar e consolidar novas bases para um Direito Administrativo reflexivo. ${ }^{5}$

\section{A discricionariedade administrativa é um dos paradigmas do Direito} Administrativo revisitado com intensidade na academia e na doutrina administrativista. As Agências Reguladoras - um dos instrumentos estatais mais importantes originados no bojo das transformações referidas - são igualmente objeto de acurados trabalhos jurídicos que buscam a sua acomodação aos ditames basilares do Estado Democrático de Direito brasileiro, consagrado constitucionalmente.

\footnotetext{
${ }^{1}$ Jacques CHEVALLIER em notável monografia sobre o Estado pós-moderno bem retrata esse momento de transformações sociais, econômicas, políticas e culturais e, por conseguinte, a necessidade de reavaliação dos institutos tradicionais de Direito Administrativo. O jurista registra, a esse respeito, que todos os Estados conheceram, em diferentes graus, transformações que questionam os princípios sobre os quais o modelo estatal se erigiu. Nas palavras do autor: "Essas transformações são indissociáveis de mutações mais profundas. De fato, tudo se passa como se as sociedades contemporâneas conhecessem, nesse início do século XXI, uma transformação profunda de seus princípios de organização: transformações que afetam, em maior ou menor medida, ainda que de diferentes modos, todas as sociedades, para além da diversidade dos seus contextos locais; transformações que atingem também todos os níveis do edifício social, bem como o conjunto das instituições (econômicas, culturais, políticas...). Para mensurar as mutações em curso, os esquemas do pensamento tradicional não são suficientes: é necessário se esforçar para construir novas ferramentas, forjar outros instrumentos de análise; $e$ a concepção tradicional de Estado deve ser reavaliada." O Estado Pós-Moderno, p. 11.

${ }^{2}$ A expressão ganhou impulso marcadamente com Gustavo BINEMBOJM em sua obra Uma Teoria do Direito Administrativo. Direitos Fundamentais, Democracia e Constitucionalização; em que o autor coloca o Direito Administrativo no "divã" e análise a "crise dos paradigmas do Direito Administrativo" para, em seguida, propor a sua releitura.

${ }^{3}$ Luís Roberto BARROSO capturou com propriedade a velocidade dos novos tempos e os seus impactos no Direito em seu A Segurança Jurídica na Era da Velocidade e do Pragmatismo.

4 Veja-se, por exemplo, a positivação da participação popular nos processos normativos por meio de audiências e consultas públicas e a edição de leis de parcerias público-privadas.

5 Sérgio GUERRA quem cunhou a fórmula da reflexividade administrativa no sentido adotado nessa dissertação de mestrado. Em linhas gerais, "a reflexividade administrativa deve conformar a capacidade de o administrador público pensar a situação concreta em si mesma para estabilizar o subsistema e minimizar a insegurança." Discricionariedade e Reflexividade - Uma Nova Teoria sobre as Escolhas Administrativas. Para conhecer com detalhes o conteúdo da referida fórmula, consultar p. 236-237 da obra.
} 
A discricionariedade das Agências Reguladoras mostra-se, assim, nesse contexto de mutações ${ }^{6}$ e ajustamentos, como tema atual e instigante.

Isso porque algumas das transformações referenciadas inicialmente ${ }^{7}$ contribuíram para a configuração de entes descentralizados, dotados de autonomia reforçada, com larga competência nos setores regulados e ampla margem de discricionariedade em sua atuação.

O incremento da discricionariedade administrativa e a sua concentração no regulador independente expuseram, assim, os agentes econômicos dos setores regulados ao maior risco do cometimento de arbitrariedades por parte das Agências Reguladoras.

Como conseqüência, o controle social e judicial das escolhas públicas, realizadas ao longo dos processos decisórios, das Agências Reguladoras passou a ser instrumento ainda mais relevante para, senão impedir, dificultar o cometimento de arbitrariedades pelo regulador.

Diante desse cenário, a presente dissertação trabalha com as seguintes hipóteses:

(i) A discricionariedade nos processos decisórios declaratórios das Agências Reguladoras, no âmbito da mediação ativa de interesses legítimos, não é incondicionada e ilimitada; $e$

(ii) As escolhas administrativas (e regulatórias) discricionárias devem ser previsíveis e passíveis de amplo e objetivo controle pelos interessados e pelos órgãos de fiscalização, especialmente pelo Poder Judiciário.

A inexistência, entretanto, de parâmetros concretos e objetivos para o acompanhamento e controle das decisões regulatórias discricionárias obsta a aferição e confrontação adequada das razões e dos critérios de decisão do regulador.

\footnotetext{
6 Esse termo, no direito brasileiro, foi difundido por Diogo de Figueiredo MOREIRA NETO que produziu duas obras analisando e avaliando os efeitos das mutações do Estado Contemporâneo no Direto. Mutações do Direito Público e Mutações do Direito Administrativo. Odete MEDUAR prefere tratar do assunto como "transformações de matrizes clássicas do Direito Administrativo" em seu Direito Administrativo em Evolução.

7 Marcadamente o policentrismo estatal, a juridicidade, a pluralidade de interesses legítimos, a alta complexidade e tecnicidade das relações sócias e econômicas e o dever de mediação estatal dos interesses dos administrados em conflito.
} 
E, por conseguinte, é inevitável questionar:

- Como enfrentar o risco das escolhas discricionárias do regulador?

O enfrentamento dessa questão passa por algumas indagações precedentes que são tratadas ao longo do trabalho:

(i) Em que medida os atos administrativos (e regulatórios) discricionários são controláveis pelo Poder Judiciário?

(ii) Como auferir, em cada caso concreto, se a decisão discricionária regulatória, no exercício da mediação ativa de interesses legítimos, é a melhor solução juridicamente possível?

Reduzir a valoração subjetiva (conveniência e oportunidade) da autoridade pública - e, pois do regulador - no exercício das escolhas públicas e ampliar os parâmetros objetivos de controle de suas decisões é um grande desafio do Estado contemporâneo.

A presente dissertação de mestrado se propõe, nessa medida, a apresentar parâmetros concretos e objetivos para a aferição, caso a caso, da correção e adequação das decisões regulatórias discricionárias.

Esta proposta tem origem em estudo de casos da Agência Nacional de Telecomunicações - ANATEL em que constatamos a ausência de critérios decisórios claros e precisos da Agência Reguladora. É, ainda, por essa razão, que a própria ANATEL é o foco dos parâmetros que cunhamos ao final deste trabalho.

Não obstante, entendemos que estes parâmetros, em função de seu caráter genérico, podem, também, contribuir para o acompanhamento e controle das decisões regulatórias discricionárias de outras Agências Reguladoras.

Reputou-se, por fim, necessário estruturar esta dissertação em três partes: PARTE I - Discricionariedade - Do Clássico ao Contemporâneo; PARTE II Discricionariedade e Arbitrariedade; e PARTE III - Em Busca da Determinação dos Motivos das Decisões Regulatórias Discricionárias. 
A PARTE I é composta pelo Capítulo I, A Discricionariedade da Administração Pública em Novos Tempos, no qual buscamos demonstrar, de maneira breve, a evolução da discricionariedade para margens mais amplas. Para tanto, traçarmos, inicialmente, as linhas gerais da discricionariedade em sua acepção clássica e, em seguida, dedicamo-nos à relação renovada entre interesse público, legalidade e discricionariedade. Este capítulo apresenta os pressupostos sobre os quais todo o trabalho se desenvolve.

A PARTE II é composta de dois capítulos. O Capítulo II, Discricionariedade versus Arbitrariedade, destina-se a abordar as consequências do mau uso da discricionariedade pelas autoridades públicas, pontuando, pois, o risco do arbítrio, do desvio de poder e da captura do regulador. O Capítulo III, A Discricionariedade da Agência Nacional de Telecomunicações nos Processos Decisórios sobre Transferência de Controle de Operadores de Serviços de Telecomunicações: Estudo de Casos, apresenta estudo de casos da ANATEL que demonstra, concretamente, a fragilidade e a hiposuficiência dos regulados em face de decisões discricionárias desparametrizadas e a dificuldade, senão impossibilidade, por ausência de critérios objetivos, de seu acompanhamento e controle por parte dos interessados e dos órgãos de fiscalização.

A PARTE III dessa dissertação também é composta por dois capítulos. O Capítulo IV, O Controle Judicial das Decisões Regulatórias Discricionárias, presta-se a apresentar o tema do controle judicial dos atos administrativos, notadamente no viés de sua extensão e alcance com relação aos atos regulatórios discricionários. E, por derradeiro, o Capítulo V, Parâmetros de Controle das Decisões Discricionárias da ANATEL, apresenta nossa proposta de parâmetros concretos e objetivos para o controle das decisões discricionárias da ANATEL. 
PARTE I - DISCRICIONARIEDADE - DO CLÁSSICO AO CONTEMPORÂNEO 


\section{NOTA PRELIMINAR}

A PARTE I desta dissertação de mestrado apresenta os seus pressupostos: notadamente a discricionariedade, em sua acepção clássica e contemporânea.

Busca-se, nessa PARTE I, composta pelo Capítulo I, A Discricionariedade da Administração Pública em Novos Tempos, demonstrar, de maneira breve, a evolução da discricionariedade para margens mais amplas.

Nesse mister, traçarmos, inicialmente, as linhas gerais da discricionariedade em sua acepção clássica (item II) e, em seguida, dedicamo-nos à relação entre interesse público, legalidade e discricionariedade ou, de uma forma reescrita, no âmbito do Estado Contemporâneo, à relação entre múltiplos interesses legítimos, juridicidade, policentrismo e discricionariedade (item III).

A questão essencial que comanda a PARTE I deste trabalho é a de perquirir qual é a relação travada hodiernamente entre interesses legítimos, juridicidade e discricionariedade no cenário regulatório?

A pertinência dessa indagação é inequívoca, haja vista que a identificação dos contornos da referida relação, aliada à identificação dos critérios decisórios das Agências Reguladoras, especialmente da ANATEL (tema objeto do Capítulo III), é fundamental para o aprimoramento e ampliação do controle judicial desses entes com base em parâmetros objetivos, tal como propomos no capítulo derradeiro desta dissertação. 


\section{CAPÍTULO I - A DISCRICIONARIEDADE DA ADMINISTRAÇÃO PÚBLICA EM NOVOS TEMPOS}

\section{I.1. Introdução.}

A discricionariedade é um dos temas centrais do Direito Administrativo ${ }^{8} \mathrm{e}$ nunca deixou de constituir preocupação de seus estudiosos em vista do dinamismo de sua evolução ao longo dos tempos. ${ }^{9}$

A discricionariedade, como anota Maria Sylvia Zanella DI PIETRO, constitui a chave do equilíbrio entre as prerrogativas públicas e os direitos individuais. De modo que, quanto maior a extensão da discricionariedade, maior o risco de violação das liberdades dos cidadãos. ${ }^{10}$

As preocupações dos administrados em torno da discricionariedade administrativa não são novidade, ao contrário, sempre estiveram presentes, ora de forma mais acentuadas, ora menos. Contemporaneamente, entretanto, tais preocupações ganham robustez em vista da ampliação do espaço discricionário das autoridades públicas e, em especial do regulador.

Esse alargamento deve-se, entre outros fatores, ao dever de mediação ativa de interesses legítimos inerente à atividade das Agências Reguladoras e à possibilidade de atuação do regulador dentro dos bordes da juridicidade.

É o que veremos nesse capítulo, antes, porém, cumpre traçar as linhas gerais do instituto tal como classicamente desenha-se na doutrina administrativista.

\footnotetext{
${ }^{8}$ Cf. Marçal JUSTEN FILHO. Curso de Direito Administrativo, p.

${ }^{9}$ Cf. Maria Sylvia Zanella DI PIETRO. Discricionariedade Técnica e Discricionariedade Administrativa, p. 75 .

${ }^{10}$ Discricionariedade Administrativa na Constituição de 1988, p. 14.
} 


\section{I.2. A Concepção Clássica de Discricionariedade Administrativa.}

$\mathrm{O}$ conceito doutrinário de discricionariedade ${ }^{11}$ longe está de ser uníssono na doutrina administrativista pátria ou estrangeira. ${ }^{12}$

Em sua acepção clássica a discricionariedade da autoridade pública é, comumente, indicada como um poder, que lhe é conferido por lei, com vistas a possibilitar a escolha de uma solução, dentre várias possíveis, ao caso concreto. ${ }^{13}$ Esse poder, muitas vezes, é referido como uma margem de liberdade de atuação da Administração Pública, consubstanciada em critérios de conveniência e oportunidade (mérito do ato administrativo) próprios da autoridade pública e, pois, nesse âmbito insindicável pelo Poder Judiciário. $^{14}$

Essa acepção evoluiu para o reconhecimento de que a discricionariedade da Administração Pública é um instrumento - para alguns expresso em um dever e para outros em uma faculdade -, autorizado e limitado por lei ${ }^{15}$, para a escolha, conveniente e oportuna da autoridade pública, de uma, dentre mais de uma, solução possível para o caso concreto. ${ }^{16}$

É, nesse sentido, a definição formulada por Celso Antonio BANDEIRA DE MELLO que aduz que a discricionariedade é a "margem de liberdade conferida pela lei ao administrador a fim de que este cumpra com o dever de integrar com sua vontade e juízo a norma jurídica, diante do caso concreto, segundo critérios subjetivos próprios, a fim de dar satisfação aos objetivos consagrados no sistema legal." 17 (grifo nosso).

\footnotetext{
${ }^{11}$ Maria Sylvia Zanella DI PIETRO registra que: “Estudando-se a evolução da Administração Pública a partir do Estado de Polícia, verifica-se que se partiu de uma idéia de discricionariedade ampla sinônimo de arbítrio e própria das monarquias absolutas, em que os atos da Administração não eram sindicáveis perante o Judiciário - para passar-se a uma fase, já no Estado de Direito, em que a discricionariedade, assim entendida, ficou reduzida a certos tipos de atos; e que chegou-se a uma terceira faze em que praticamente desapareceu essa idéia de discricionariedade e esta surgiu como poder jurídico, ou seja, limitado pela lei." Discricionariedade Administrativa na Constituição de 1988, 14.

${ }^{12}$ Cf. Miguel Sánchez Morón. Discrecionalidad Administrativa y Control Judicial, p. 9. Cf, também, Karl Engisch, Introdução ao Pensamento Jurídico, p. 214.

${ }^{13}$ Cf. José CRETELLA JUNIOR. Controle Jurisdicional do Ato Administrativo, p. 150. Cf., também, Hely Lopes MEIRELLES, Direito Administrativo Brasileiro, p. 110 e ss.

${ }^{14} \mathrm{~A}$ matéria atinente ao mérito do ato administrativo (conveniência e oportunidade) e de seu controle é tratada detalhadamente no Capítulo IV da presente dissertação de mestrado.

${ }^{15}$ Sólido é o magistério de Maria Sylvia Zanella DI PIETRO nesse sentido. “(...) a discricionariedade implica liberdade de atuação nos limites traçados pela lei; se a Administração ultrapassar esses limites, sua decisão passa a ser arbitrária.”. Discricionariedade Administrativa na Constituição de 1988, p. 67.

${ }^{16}$ Para além desses limites ter-se-ia ação arbitrária da Administração Pública, como veremos no Capítulo II.

${ }^{17}$ Curso de Direito Administrativo, p. 414. No mesmo sentido, Marçal JUSTEN FILHO. Curso de Direito Administrativo, p. 142.
} 
Maria Sylvia Zanella DI PIETRO, por sua vez, que afirma ser a discricionariedade a "faculdade que a lei confere à Administração para apreciar o caso concreto, segundo critérios de conveniência e oportunidade, e escolher uma dentre duas ou mais soluções, todas validas para o Direito." 18 (grifo nossos)

A instrumentalidade da discricionariedade é, também, destacada por Eva Desdentado DAROCA, uma das estudiosas contemporâneas do tema, que afirma que a discricionariedade "consiste em la realización de elecciones entre diferentes alternativas com la finalidad de ejercer una potestad conferida por el ordenamiento jurídico y que este, sin embargo, no há regulado plenamente. La discrecionalidad es, por um modus operandi que se caracteriza por los siguintes rasgos:1) supone la adopción de decisiones dentro de um margen de libre apreciación dejado por el ordenamiento jurídico, 1) implica um acto de elección sobre la base de argumentos valorativos acerca de los cuales personas razonables pueden diferir, y 3) la elección se adopta siempre conforme a critérios valorativos extrajurídicos. " 19

A doutrina administrativista utiliza-se, ainda, com frequiência, da contraposição entre atos vinculados e discricionários para elucidar o conteúdo de discricionariedade.

Assim, afirma-se que a ação vinculada da Administração Pública apresenta-se nas situações em que a lei predica com exatidão qual deve ser a conduta da autoridade pública diante do caso concreto, isto é, a lei afirma qual é a o único comportamento possível a ser adotado por essa, não lhe deixando qualquer espaço de opção. ${ }^{20} \mathrm{Em}$ contrapartida, a ação discricionária da Administração Pública verifica-se diante de situações em que a lei deixa certa margem de decisão diante do caso concreto, de tal modo que a autoridade pública poderá optar por uma dentre várias soluções possíveis, todas válidas perante o Direito, segundo critérios de conveniência e oportunidade. ${ }^{21}$

\footnotetext{
${ }^{18}$ Direito Administrativo, p. 197. Cf., também, Odete MEDAUAR. Direito Administrativo Moderno, p. 108. E Afonso Rodrigues QUEIRÓ. A Teoria do Desvio de Poder em Direito Administrativo, p. 77-78.

${ }^{19}$ Los Problemas del Control Judicial de la Discrecionaldad Técnica, p. 22.

${ }^{20}$ Nas palavras de Hely Lopes MEIRELLES: “Atos vinculados ou regrados são aqueles para os quais a lei estabelece os requisitos e condições de sua realização. Nessa categoria de atos, as imposições legais absorvem, quase que por completo, a liberdade do administrador, uma vez que sua ação fica adstrita aos pressupostos estabelecidos pela norma legal para a validade da atividade administrativa." Direito Administrativo Brasileiro, p. 158.

${ }^{21}$ Cf. Maria Sylvia Zanella DI PIETRO. Direito Administrativo p. 201. Nas palavras de Hely Lopes MEIRELLES: "Atos discricionários são os que a Administração pode praticar com liberdade de escolha de seu conteúdo, de seu destinatário, de sua conveniência, de sua oportunidade e do modo de sua realização.”. Direito Administrativo Brasileiro, p. 160.
} 
A doutrina administrativista destaca que a diferença entre os atos vinculados e os atos discricionários ${ }^{22}$ está em que nos primeiros a Administração Pública não dispõe de qualquer liberdade, uma vez que a lei já regulou, antecipadamente e em todos os aspectos, o comportamento a ser por essa seguido, enquanto que nos atos discricionários remanesce alguma liberdade à autoridade pública para decidir, diante das particularidades do caso concreto, segundo critérios próprios de avaliação, qual a solução a ser adotada.

Ressalta-se, ainda, que nos atos discricionários os elementos competência, forma e finalidade ${ }^{23}$ são subordinados ao que a lei dispõe, como qualquer outro ato vinculado; de modo que não haveria, nesse sentido, atos inteiramente discricionários. A discricionariedade, entretanto, pode residir no objeto (conteúdo) e nos motivos dos atos administrativos. $^{24}$

A fonte da discricionariedade, como vimos, é a lei. Embora não haja consenso na doutrina administrativista, é possível afirmar que a discricionariedade administrativa está presente, ao menos, nas seguintes situações: (i) de lassidão do texto legal (decorrente da imprecisão inerente ao uso da linguagem); e (ii) de expressa autorização legislativa (decorrente da impossibilidade de se antever todos os comportamentos possíveis da autoridade pública). ${ }^{25}$

\footnotetext{
${ }^{22}$ A doutrina administrativista esclarece que a expressão é imprópria e deve ser utilizada no sentido de "ato praticado no exercício de apreciação discricionária”. Cf. Celso Antonio BANDEIRA DE MELLO. Discricionariedade e Controle Jurisdicional, p. 18. Nas palavras de José CRETELLA JUNIOR: “Sem o poder discricionário inexistiria o ato administrativo discricionário; sem este, o poder discricionário seria inócuo, inoperante, ineficaz, perdendo sua razão de ser. O poder discricionário traça as coordenadas da ação administrativa. Marca-lhe o terreno. $O$ ato administrativo, com base nesse poder, define-se, ao ser editado, delineando-se com arquitetônica, própria dentro dos limites demarcados. O poder discricionário não é causa do ato, mas sua condição vital de existência. Não lhe dá origem. Condiciona-lhe a vida, preparando-lhe o nascimento." Ato Administrativo - Tridimensão da Discricionariedade, p. 36. Para uma visão acerca dos poderes discricionário e vinculado na doutrina tradicional ver, dentre outros: Oswaldo Aranha BANDEIRA DE MELLO. Princípios Gerais de Direito Administrativo. Themístocles Brandão CAVAlCANTI. Do Poder Discricionário. Hely Lopes MEIRELlES. Os Poderes do Administrador Público.

${ }^{23}$ A finalidade do ato administrativo é seu ponto de maior vulnerabilidade para a prática de arbitrariedades, já que pode ser desvirtuado em face de comandos legais genéricos.

${ }^{24}$ Cf. dentre outros, Celso Antonio BANDEIRA DE MELLO. Curso de Direito Administrativo, p. 424. E Maria Sylvia Zanella DI PIETRO. Direito Administrativo, p. 202 e ss. Marcos Paulo VERISSIMO bem destaca a esse respeito que hodiernamente “(...) percebe-se que a identificação da discricionariedade com uma total liberdade da administração para a avaliação de determinados elementos do ato administrativo (conveniência, oportunidade e conteúdo) faz com que esta ocorra, verdadeiramente, em cada vez mais raras ocasiões, todas elas estabelecidas claramente em lei, e nenhuma delas coincidente com hipótese em que a lei é simplesmente vaga, ou utiliza conceitos abertos ou indeterminados." Controle Judicial da Atividade Normativa das Agências de Regulação Brasileiras, p. 391.

${ }^{25}$ Cf. Floriano de Azevedo MARQUES. Discricionariedade Administrativa e Controle Judicial, p. 191. A essas "causas normativas geradoras de discricionariedade", Celso Antonio BANDEIRA DE MELLO
} 
Os limites da discricionariedade, por sua vez, também remontavam exclusivamente à lei e, mais recentemente, compreendem, os princípios gerais do direito e aos princípios próprios dos Estados Democráticos de Direito, como veremos no III. 2. e, especificamente no que tange ao controle da discricionariedade no Capítulo IV.

\section{I.2.1. A Discricionariedade Técnica.}

O tema da discricionariedade técnica está diretamente relacionado ao tema do controle judicial dos atos administrativos. Isso porque, caso se trate efetivamente de discricionariedade administrativa, ou de modalidade desta, seria vedado ao Poder Judiciário controlar as razões de decisão da autoridade pública, isto é, adentrar no mérito da decisão tomada com base em discricionariedade técnica. ${ }^{26}$

O tema desborda-se, também, indiretamente, para o tema dos conceitos jurídicos indeterminados e deste retorna à questão principal do controle judicial. Assim, se da aplicação dos conceitos jurídicos indeterminados ao caso concreto se apresentar mais de uma solução possível, haveria discricionariedade decisória da autoridade pública e, pois, a decisão daí resultante não poderia ser sindicada pelo Poder Judiciário; em contrapartida, se dessa aplicação resultasse uma única solução possível, estar-se-ia diante de decisão vinculada, razão pela qual esta poderia sofrer o controle judicial. ${ }^{27}$

acrescenta, ainda, que a discrição pode resultar da finalidade da norma, embora reconheça que seu entendimento seja absolutamente minoritário nesse aspecto. $\mathrm{O}$ autor afirma que a finalidade aponta para valores e palavras que conotam conceitos plurissignificativos e, por isso, podem dar ensejo a opiniões divergentes sobre o sentido dos termos legais. Discricionariedade e Controle Jurisdicional, p. 19. Com efeito, de acordo com a doutrina administrativista majoritária, interpretação e discricionariedade não se confundem. Marçal JUSTEN FILHO assevera a esse respeito que: “(...) ainda que a interpretação-aplicação envolva algum tipo de contribuição pessoal do aplicador, isso não equivale a identificar a atividade de aplicação do direito com a discricionariedade administrativa. (...) A diferença entre interpretação e discricionariedade reside na opção adotada pelo legislador. A discricionariedade é o modo de construção da norma jurídica caracterizado pela atribuição ao aplicador do encargo de produzir a solução por meio de ponderação quanto às circunstâncias. Ou seja a discricionariedade significa que a lei atribuiu ao aplicador o dever-poder de realizar a escolha. Já a interpretação corresponde a uma tarefa de (re)construção da vontade normativa estranha e alheia ao aplicador.O intérprete não atribui sua conclusão a um juízo de conveniência próprio, mas ao sistema jurídico.” Curso de Direito Administrativo, p. 143-144.

${ }^{26}$ A discussão doutrinária a esse respeito é reportada no Capítulo IV da presente dissertação, onde o tema do controle das decisões discricionárias, inclusive com base em critérios técnicos, é tratado com mais vagar. Desde já, entretanto, manifestamos nosso posicionamento divergente ao entendimento de que as decisões regulatórias, fundadas em discricionariedade técnica, sejam imunes ao controle judicial. Defendemos, ao contrário, que dessas decisões cabe amplo e objetivo controle judicial, como veremos na Parte III deste trabalho.

27 "O problema dos conceitos jurídico indeterminados surge a partir do momento em que a ampliação dos horizontes do direito se mostra tão extraordinária que a lei perde a capacidade de regular precisamente 
Não há, contudo, consenso na doutrina administrativista acerca da natureza da discricionariedade técnica; não há também posições polarizadas sobre o tema, uma vez que não verificamos, em nosso estudo, uniformidade de entendimentos. Alguns autores reconhecem na discricionariedade técnica uma modalidade de discricionariedade administrativa, outros assentam que de discricionariedade não se trata. Vale à pena conhecer alguns desses posicionamentos.

Antônio Francisco SOUSA indo às origens do instituto constatou que BERNATZIK ${ }^{28}$ pretendia, sob o conceito de discricionariedade técnica, englobar as decisões administrativas que - embora não fossem discricionárias - deveriam estar imunes ao controle judicial, em vista da sua complexidade técnica. ${ }^{29}$

Odete MEDAUAR assevera que não se trata de outra espécie de discricionariedade, mas da escolha da solução a adotar pela utilização de critérios especializados - técnicos ou científicos. A autora explica que nem sempre há concordância técnica ou científica, de modo que, em havendo mais de uma solução possível, como consequiência da aplicação desses critérios, estar-se-ia diante de discricionariedade da autoridade pública, sem que se possa falar em modalidade diferente desse poder; do contrário, em caso de uma única solução possível, estar-se-ia diante de poder vinculado. ${ }^{30}$

Marçal JUSTEN FILHO afirma que a discricionariedade técnica não se configuraria como uma situação de discricionariedade propriamente dita. O autor explica que, embora, ambas assemelhem-se em virtude da ausência de solução predeterminada em lei, diferenciam-se entre si com relação à margem de autonomia atribuída à autoridade pública encarregada de exaurir o sentido legal. O autor assevera, entretanto, que existem situações em que é impossível distinguir-se a discricionariedade técnica da

todas as situações concretas subsumíveis á ordenação jurídica, deixando de atribuir prescrições definidas para cada uma das situações. É obrigada, então, a expressar-se em termos cada vez mais genéricos, mas fluidos, mais imprecisos, definindo normas e objetivos gerais cuja interpretação é que revelará, em cada situação concreta, e à vista de seus elementos concretos correspondentes, a prescrição jurídica aplicável." Marcos Paulo VERISSIMO. Controle Judicial da Atividade Normativa das Agências de Regulação Brasileiras, p. 401. Sobre o tema ver, dentre outros, Sérgio GUERRA. Controle Judicial dos Atos Regulatórios. Regina Helena COSTA. Conceitos Jurídicos Indeterminados e Discricionariedade Administrativa. Rita TOURINHO. Discricionariedade Administrativa perante os Conceitos Jurídicos Indeterminados. Eros GRAU. Direito, Conceitos e Normas Jurídicas.

${ }^{28}$ A expressão discricionariedade técnica foi utilizada pela primeira vez, em 1864, por BERNATZIK. Cf. Maria Sylvia Zanella DI PIETRO. Discricionariedade Técnica e Discricionariedade Administrativa, p. 78.

29 Cf. Maria Sylvia Zanella DI PIETRO. Discricionariedade Técnica e Discricionariedade Administrativa, p. 78-79.

${ }^{30}$ Direito Administrativo Moderno, p. 112. 
discricionariedade propriamente dita, especialmente em situações em que, após a aplicação de critérios técnico-científicos, se constata a existência de múltiplas opções à autoridade pública. Para o autor, a escolha por uma ou outra opção far-se-á segundo um juízo de conveniência e oportunidade e, portanto, político. $^{31}$

Diogo de Figueiredo MOREIRA NETO distingue dois tipos de discricionariedade, o que denomina discricionariedade político-administrativa ("geralmente de amplo espectro de alternativas válidas que devem ser avaliadas por políticos e burocratas") de discricionariedade técnica ("geralmente comportando opções mais restritas e que devem ser consideradas à luz de regras científicas para que se determine a melhor escolha”). Para o autor a discricionariedade técnica é o "próprio fundamento de validade das normas reguladoras que devem ser baixadas pelas agências. ",32

Maria Sylvia Zanella DI PIETRO, por sua vez, afirma que "[n]o caso da discricionariedade técnica, não há discricionariedade propriamente dita (...) não há opções a serem feitas por critérios de oportunidade e conveniência. Não há decisão política a ser tomada conforme avaliação do interesse público. Existe uma solução única a ser adotada com base em critérios técnicos fornecidos pela ciência." 33

Carlos Ari SUNDFELD e Jacintho Arruda CÂMARA afirmam que em determinadas situações a lei confere à Agência Reguladora uma discricionariedade técnica na tomada de decisões que envolvem fundamentalmente uma definição de política regulatória. $^{34}$

Em sentido próximo, Floriano de AZEVEDO MARQUES, embora não se refira expressamente à discricionariedade técnica, admite um novo tipo de discricionariedade, pautado na lei, para a atuação das Agências Reguladoras, com vistas à implementação dos objetivos do setor regulado. ${ }^{35}$

No direito estrangeiro, a multiplicidade de posicionamentos sobre discricionariedade técnica não é diferente.

\footnotetext{
${ }^{31}$ O Direito das Agências Reguladoras Independentes, p. 525-532.

${ }^{32}$ Mutações de Direito Administrativo, p. 221.

${ }^{33}$ Discricionariedade Técnica e Discricionariedade Administrativa, p. 91.

${ }^{34}$ Controle Judicial dos Atos Administrativos: As Questões Técnicas e os limites da Tutela de Urgência, p. 35.

${ }^{35}$ A Nova Regulação Estatal e as Agências Independentes, p. 95.
} 
Afonso Rodrigues QUEIRÓ sustenta que se a lei recorre a conceitos científicos não deixa discricionariedade à autoridade pública. ${ }^{36}$

Miguel Sánchez MORÓN afirma que há discricionariedade técnica da autoridade pública nos casos em que a lei lhe confere um âmbito de decisão atrelado a questões de natureza exclusivamente técnicas. Sustenta, ainda, o autor que muitos desses casos estão delimitados por conceitos jurídicos indeterminados. ${ }^{37}$

Massimo Severo GIANNINI, por sua vez, reconhece que há direta correlação entre discricionariedade técnica e conceitos jurídicos indeterminados que demandem, para sua aplicação, critérios técnicos. Para o autor italiano, discricionariedade pura e discricionariedade técnica são institutos distintos; na primeira, estariam abrangidas as situações em que existam alternativas para a satisfação do interesse público e, na segunda, situações em que seja necessária a utilização de critérios técnicos para a apreciação de um fato delimitado por um conceito jurídico indeterminado. Assim, a discricionariedade técnica, segundo o autor, não deixaria margem de liberdade para decisão à autoridade pública, estando estritamente vinculada por regras e critérios técnicos. Daí concluir o jurista italiano que discricionariedade e critérios técnicos não são conciliáveis. ${ }^{38}$

Em que pesem os respeitáveis posicionamentos contrários apresentados acima, perfilhamos do entendimento daqueles que entendem que é inerente ao exercício da regulação econômica a conferência de discricionariedade (técnica, imprópria, ou qualquer que seja a nomenclatura de preferência) ${ }^{39}$ às Agências Reguladoras, com vistas a que possam exercer, com efetividade, as competências que lhe foram atribuídas nas respectivas leis de criação.

Não se pode negar, também, que por se tratar de setores específicos, a regulação comporta termos e expressões que requererem, ora mais, ora menos, conhecimentos técnicos para a sua aplicação. ${ }^{40}$

\footnotetext{
${ }^{36}$ A Teoria do Desvio de Poder em Direito Administrativo, p. 60.

${ }^{37}$ Discrecionalidad Administrativa y Control Judicial, p. 129.

${ }^{38}$ Diritto Ammnistrativo, p. 483 e ss.

39 Cf. Maria Sylvia Zanella DI PIETRO. Discricionariedade Técnica e Discricionariedade Administrativa, ' .75.

${ }^{40}$ Pressupõe-se que a regulamentação setorial ao se valer destes termos e expressões busca atender ao fim que lhe é preordenado em lei; do contrário, a própria regulamentação seria arbitrária. O tema da arbitrariedade da autoridade pública será tratado no Capítulo II.
} 
Não importa dizer, frise-se, que em face de decisões discricionariedade das Agências Reguladoras ou, diante de decisões que importem na aplicação de conceitos técnico-jurídicos indeterminados, não caberia o controle judicial.

Entendemos que das decisões regulatórias discricionárias (que envolvam ou não a aplicação de conceitos técnico-jurídicos indeterminados) cabe amplo e objetivo controle do Poder Judiciário, como pretendemos demonstrar ao longo deste trabalho.

A necessidade de controle irrestrito e concreto das decisões regulatórias discricionárias revela-se ainda mais importante, nos dias atuais, em que a discricionariedade administrativa e, por conseguinte, a discricionariedade das Agências Reguladoras, apresenta-se mais ampla que em outros tempos. Esse será o tema dos itens seguintes.

\section{I.3. A Discricionariedade no Estado Contemporâneo.}

O Estado atravessou nos últimos dois séculos três fases diversas e bem definidas. A primeira, identificada como pré-modernidade ou Estado Liberal, na virada do século XIX e início do século XX, que exibia um Estado com funções reduzidas e cujo objeto principal era a proteção dos cidadãos (especialmente da expressão econômica dos direitos individuais) em face do próprio Poder Público. A segunda, referida como modernidade ou Estado Social, iniciada na segunda década do século XX, em que o Estado assumiu diretamente importante papel na economia, especialmente como provedor das necessidades sociais e cultor dos direitos sociais. E a terceira, correspondente a pósmodernidade ou Estado Contemporâneo, principiada na última quadra do século XX, marcada pelo reposicionamento do Estado na economia (especialmente a partir da década de 90, no Brasil), pela globalização e tecnização, pelos direitos difusos e pela alteração da relação entre Estado e cidadãos para nível mais próximo e complexo. ${ }^{41}$

Esse último período é marcado, em linhas mais específicas, pela pluralidade de interesses legítimos conviventes e contrapostos na sociedade contemporânea, cada vez

41 Cf. Luís Roberto BARROSO. Agências Reguladoras. Constituição, Transformações do Estado e Legitimidade Democrática, p. 59 e ss. Diogo de Figueiredo MOREIRA NETO, assim, elenca os fenômenos que marcam as transformações na pós-modernidade: (i) a consciência dos cidadãos dos próprios interesses; (ii) maior nitidez dos valores; (iii) globalização; (iv) pluralização e crescimento das demandas; (v) desenvolvimento do conceito de interesses transindividuais; (vi) surgimento do público não estatal; e (vii) reinvindicação de maior participação. Mutações do Direito Administrativ, p. 8. 
mais complexa, pelo incremento dos bordes de atuação administrativa para além da legalidade estrita e pela descentralização dos pólos de decisão acarretaram no aumento das margens discricionárias da Administração Pública.

Em razão destes fatores, dentre outros, o Estado Contemporâneo apresenta-se, com poder discricionário alargado com relação ao período anterior. ${ }^{42}$ Os próximos itens são dedicados ao estudo desses fenômenos e aos seus impactos na discricionariedade administrativa.

\section{I.3.1. A Discricionariedade em face da Pluralidade de Interesses}

\section{Legítimos Contrapostos e a sua Mediação Ativa pelo Regulador.}

Trataremos, a seguir, de um dos pontos basilares sobre o qual se sustenta a presente dissertação de mestrado: o reconhecimento de que, contemporaneamente, coexistem múltiplos interesses legítimos - que ora e vez se embatem - e, por conseguinte, criam o dever de sua mediação ativa por parte da Administração Pública e, mais especificamente, das Agências Reguladoras. Essa ordem de fatores acarreta, como veremos, o incremento da discricionariedade do regulador setorial, já ampla em razão da própria natureza de sua atividade. ${ }^{43}$

A admissão de uma pluralidade de interesses legítimos conviventes e contrapostos, em uma relação dinâmica, na atualidade passa, impreterivelmente, por se conhecer os debates teóricos da doutrina administrativista em torno do tema do interesse público e, em especial, da supremacia do interesse público sobre o privado.

Há muito se reconhece a centralidade da noção de interesse público para o Direito Administrativo. ${ }^{44}$ Comumente, a doutrina administrativista atribui ao interesse público as raízes do regime jurídico-administrativo e a base justificadora da existência das prerrogativas da Administração Pública. O interesse público, portanto, seria o móvel da

\footnotetext{
${ }^{42}$ Diversos fatores são apontados na doutrina para explicar o incremento da discricionariedade administrativa contemporaneamente. Optamos pelos fatores enunciados, uma vez que esses nos parecem ter relação direta com o objeto da presente dissertação de mestrado.

${ }^{43}$ Esse tema é tratado com mais vagar no Capítulo III.

${ }^{44}$ Odete MEDAUAR sintetiza a expressão da noção de interesse público nessa seara do direito: “A noção de interesse público aparece, ao mesmo tempo, como fundamento, limite e instrumento de poder, configura medida e finalidade da função administrativa.”. O Direito Administrativo em Evolução, p. 185-186. Cf., também, Floriano de Azevedo MARQUES NETO, Regulação Estatal e Interesses Públicos, p. 77 e ss.
} 
Administração Pública e, concomitantemente, o fim a ser, por essa, buscado, explicandose, assim e, apenas assim, a verticalidade das relações entre Administração Pública e administrados. $^{45}$

A expressão do interesse público dar-se-ia por meio de dois princípios: o princípio da supremacia do interesse público sobre o privado e o princípio da indisponibilidade do interesse público. ${ }^{46}$

Em razão do escopo deste trabalho nos focaremos no tratamento do princípio da supremacia do interesse público sobre o privado. ${ }^{47}$

Acerca do princípio da supremacia do interesse público sobre o privado duas são as correntes doutrinárias: uma clássica e outra contestadora, conforme identificado por Luís Roberto BARROSO. ${ }^{48}$

A doutrina administrativista clássica ${ }^{49}$ considera que o interesse público corresponderia ao interesse coletivo e ao bem comum - e não ao somatório dos interesses individuais ${ }^{50} \mathrm{e}$ confere ao princípio da supremacia do interesse público sobre o privado

\footnotetext{
${ }^{45}$ Cf. Daniel SARMENTO. Interesses Públicos VS. Interesses Privados na Perspectiva da Teoria e da Filosofia Constitucional, p. 23-24.

${ }^{46}$ Celso Antonio BANDEIRADE MELLO afirma que a supremacia do interesse público sobre o privado e a indisponibilidade do interesse público são axiomas, essenciais ao regime jurídico-administrativo, e que somente à luz deles é que devem ser compreendidos todos os demais princípios. Curso de Direito Administrativo, p. 58 e ss.
}

${ }^{47}$ Para uma visão deste princípio no Direito Comparado ver O Princípio da Supremacia do Interesse Público sobre o Privado no Direito Positivo Comparado: Expressão do Interesse geral da Sociedade e da Soberania Popular. Hildemberg Alves da FROTA.

${ }^{48}$ Interesses Públicos VS. Interesses Privados na Perspectiva da Teoria e da Filosofia Constitucional, prefácio.

${ }^{49}$ Alguns doutrinadores que compõem essa corrente e seus respectivos textos sobre o tema são: Maria Sylvia Zanella DI PIETRO, O Princípio da Supremacia do Interesse Público: Sobrevivência diante dos Ideais do Neoliberalismo. Celso Antonio BANDEIRA DE MELLO, Curso de Direito Administrativo, dentre outros textos do autor; Maçal JUSTEN FILHO, Curso de Direito Administrativo, Lucia Valle FIGUEIREDO, Curso de Direito Administrativo, Edmir Netto de ARAÚJO, Curso de Direito Administrativo; Diógenes GASPARINI, Direito Administrativo; José dos Santos CARVALHO FILO, Interesse Público: Verdades e Sofismas; Irene Patrícia NOHARA, Reflexões Críticas acerca da Tentativa de Desconstrução do Sentido da Supremacia do Interesse Público no Direito Administrativo; Fábio Medina OSÓRIO, Existe uma Supremacia do Interesse Público sobre o Privado no Direito Administrativo?

${ }^{50}$ Cf. Odete MEDAUAR, Direito Administrativo Moderno, p. 145. Cf. Celso Antonio BANDEIRA DE MELLO, A Noção Jurídica de Interesse Público, p. 181 e ss. Cf. também, José dos Santos CARVALHO FILHO, Interesse Público: Verdades e Sofismas. José dos Santos CARVALHO FILHO afirma, nesse sentido, que: "O interesse público, portanto, se antagoniza com a idéia do isolacionismo e do egocentrismo. Ultrapassa as fronteiras dos interesses individuais e representa uma demanda de satisfação por parte das comunidades. Ainda que nem sempre sejam personalizados, os grupos sociais têm anseios próprios e interesses específicos a serem satisfeitos. Quando o Estado administra tais interesses, deve ter em mira os grupos e os benefícios que reclamam. Infere-se, pois, que o interesse público não é o somatório dos 
valor metodológico, assentado na premissa de uma dualidade contraposta entre público e privado, de modo que diante de eventual conflito entre interesses público e privado, o primeiro, indubitavelmente, deveria prevalecer.

Floriano de Azevedo MARQUES estudou a fundo o tema e assim sintetiza a concepção clássica de interesse público:

"Ao formular o princípio a partir do conceito de supremacia, o paradigma em tela já prenuncia a idéia de que o interesse público se contrapõe aos interesses privados, razão por que deverá predominar, prevalecer, superar, sobrepor os interesses privados. (...) Segue daí subjazer à própria noção de interesse público, sobre o qual se apóia o Direito Administrativo, um pressuposto de oposição, de embate, de afirmação pela negação, segundo o qual a consagração do interesse público se oporia essencialmente aos interesses privados e, destarte, somente se efetivaria a partir de algum sacrifício ou restrição de interesses particulares." ${ }^{51}$ (grifos nossos)

O interesse público, na concepção clássica da doutrina administrativista, é, assim, considerado, a um só tempo, antagônico ao interesse privado e superior a esse.

Mais que isso, desta formulação, o autor extrai o caráter marcadamente singularizado, indivisível e único de que se reveste a noção de interesse público, ilustrando-o através da definição pronominal singular "o" interesse público em contraposição aos interesses privados que seriam plurais. ${ }^{52}$

A doutrina administrativista clássica, portanto, reconhece, em abstrato, a existência de um interesse público único e absoluto que deve preponderar sobre os interesses privados nas situações de embate entre eles. É dizer, assim, que diante de caso concreto, eventual conflito de interesses seria dirimido com a identificação do interesse público a prevalecer.

interesses individuais dos componentes do grupo social, mas traduz interesse próprio, coletivo, gerador de satisfação geral, e não individual; enfim, busca o bem comum.” (p. 73).

${ }^{51}$ Regulação Estatal e Interesses Públicos, p. 165.

${ }^{52}$ Cf. Floriano de Azevedo MARQUES. Regulação Estatal e Interesses Públicos, p. 85-86 e 159-162. Para o autor não existiria um único interesse público, mas múltiplos interesses públicos dotados de legitimidade social consubstanciados nas classes de interesses transindividuais (especiais e difusos). 
A doutrina administrativista contestadora ${ }^{53}$, por sua vez, não reconhece o princípio da supremacia do interesse público sobre o privado tal como cunhado e justificado classicamente. Esta corrente doutrinária, com a qual perfilhamos, não atribui, por conseguinte, qualquer valor metodológico ao princípio da supremacia do interesse público sobre o privado; ao contrário, posiciona-se no sentido de que esse deve ser desconstruído ou reformulado ${ }^{54}$, com vistas à identificação do interesse legítimo prevalecente, caso a caso, por meio do exercício de análise e de ponderação de todos os interesses em jogo no caso concreto.

Essa corrente doutrinária ganhou robustez com a publicação do artigo intitulado "Repensando o Princípio da Supremacia do Interesse Público sobre o Privado", de Humberto ÁVILA. ${ }^{55}$

Em síntese, Humberto ÁVILA não atribui ao princípio da supremacia do interesse público sobre o privado a natureza de uma norma-princípio, mas uma regra de preferência em caso de colisão entre interesses públicos e privados. $\mathrm{O}$ autor defende,

${ }^{53}$ Cf. Humberto ÁVILA, Repensando o Princípio da Supremacia do Interesse Público sobre o Privado; Gustavo BINEMBOJM, Da Supremacia do Interesse Público ao Dever de Proporcionalidade: um novo paradigma para o Direito Administrativo; Floriano de Azevedo MARQUES, Regulação Estatal e Interesses Públicos; Odete MEDAUAR, Direito Administrativo Moderno; Patrícia BAPTISTA, Transformações do Direito Administrativo; Marçal JUSTEN FILHO, Curso de Direito Administrativo. Daniel SARMENTO, Interesses Públicos VS. Interesses Privados na Perspectiva da Teoria e da Filosofia Constitucional; Paulo Ricardo Schier, Ensaio sobre a Supremacia do Interesse Público sobre o Privado e o Regime Jurídico dos Direitos Fundamentais.

${ }^{54}$ Maria Sylvia Zanella DI PIETRO talvez seja a maior crítica desta corrente doutrinária, vejam-se algumas de suas recentes considerações a esse respeito: "A doutrina que se considera inovadora ou incide no erro de acabar com o princípio da supremacia do interesse público (o que equivaleria à negação dos próprios fins do Estado) ou incide no erro de achar que está inovando, quando, na realidade, está fazendo afirmações que desde longa data são amplamente aceitas pela doutrina e pela jurisprudência. Muitos exageram intencionalmente os efeitos funestos do princípio, para depois se apresentarem como os salvadores dos direitos fundamentais. Só que parece não terem percebido que esses direitos existem e são reconhecidos desde longa data e sempre conviveram com o princípio da supremacia do interesse público. Essa doutrina compõe o chamado direito administrativo econômico, que se formou e vem crescendo na mesma proporção em que cresce a proteção do interesse econômico em detrimento de outros igualmente protegidos pelo ordenamento jurídico brasileiro." Segue a autora: "A doutrina que se considera inovadora compõe, sob certo aspecto, uma ala retrógrada, porque prega a volta de princípios próprios do liberalismo, quando se protegia apenas uma classe social e inexistia a preocupação com o bem comum, com o interesse público. Ela representa a volta aos ideais de fins do século XVIII. As consequências funestas do liberalismo recomendam cautela na adoção dessas idéias, até porque se opõem aos ideais maiores que constam do preâmbulo e do título inicial da Constituição, para valorizarem excessivamente determinados princípios do capítulo da ordem econômica, privilegiando a liberdade de iniciativa e de competição." E, ainda: "É uma doutrina que caminha na contramão de direção, quando se considera também que no próprio âmbito do direito privado (de origem individualista), é crescente a influência do direito público e a preocupação com o social em detrimento do individual." O Princípio da Supremacia do Interesse Público: Sobrevivência diante dos Ideais do Neoliberalismo, p. 100-101.

${ }^{55}$ In: O Direito Público em Tempos de Crise: Estudos em Homenagem a Ruy Ruben Ruschel, 1998, posteriormente republicado em outros diversos meios jurídicos. 
ainda, que tal "princípio" não é apto a justificar o sistema jurídico-administrativo e a verticalidade da relação Estado-cidadão haja vista que: (a) se trata de um postulado éticopolítico; (b) os interesses privados são indissociáveis do interesse público; e (c) as relações jurídico-administrativas se apresentam multipolarizadas (e não bipolarizadas). Humberto ÁVILA conclui, assim, que se impõe à Administração Pública o dever de ponderação dos interesses envolvidos em cada caso concreto, inclusive dos interesses públicos existentes e, bem assim, da medida de restrição dos interesses privados, com vistas à máxima realização dos direitos envolvidos. ${ }^{56}$

Gustavo BINENBOJM sustenta, ainda, nessa mesma linha que, contemporaneamente, não há como conciliar com o ordenamento jurídico pátrio um princípio que - ignorando as nuances do caso concreto - pré-estabeleça que a melhor solução consubstancia-se na preponderância do interesse público, afastando-se, assim, antecipadamente, a possibilidade de qualquer processo de ponderação e, fechando as portas para os interesses privados que estejam envolvidos. ${ }^{57}$

Ainda sobre o caráter de supremacia do interesse público sobre o privado, Alexandre Santos de ARAGÃO, anota que a pré-ponderação dos interesses envolvidos em cada caso, baseada em um pressuposto de que o interesse público seria superior aos interesses individuais, deve dar lugar a ponderação dos interesses in concreto. ${ }^{58}$

Acerca da relação entre interesses públicos e interesses privados, Floriano de Azevedo MARQUES registra que "[a]o menos nos dias de hoje, interesses legítimos, mediatos ou imediatos, de um particular não podem significar automaticamente um interesse contrário aos desígnios públicos", ao contrário, "[t]em-se que reconhecer um largo e crescente campo em que o atendimento dos interesses dos particulares nada mais é do que a consagração do interesse público. 'De tal forma que o mundo dos interesses de

\footnotetext{
${ }^{56}$ Repensando o Princípio da Supremacia do Interesse Público sobre o Particular, p. 99-127. Fábio Medina OSÓRIO dedicou-se a responder à Humberto ÁVILA, por meio de artigo intitulado Existe uma Supremacia do Interesse Público sobre o Privado no Direito Administrativo?, no qual o autor sustenta que o princípio da supremacia do interesse público sobre o privado é uma verdadeira meta-regra para a Administração Pública em vista da sua funcionalidade de condicionar os demais princípios e regras a esse cânone.

${ }^{57}$ Da Supremacia do Interesse Público ao Dever de Proporcionalidade: Um Novo paradigma para o Direito Administrativo, p. 145.

${ }^{58}$ A Supremacia do Interesse Público no Advento do Estado de Direito e na Hermenêutica do Direito Público Contemporâneo, p. 3.
} 
que são portadores os sujeitos públicos se mostra idêntico ao mundo dos interesses de que são portadores os sujeitos privados". 59

Jacques CHEVALIER assevera que atualmente deve-se enfocar o interesse público como um elo de mediação de interesses privados dotados de legitimidade. ${ }^{60}$

Jesús González PÉREZ afirma, no mesmo sentido, que “[o]s interesses públicos e os interesses privados estão implicados entre si até o ponto em que qualquer interesse público é, também, interesse privado." 61

Elucidando o ponto fulcral dessa discussão Floriano de Azevedo MARQUES assevera que diante de conflitos-limite, isto é, de confronto entre interesses públicos primários $^{62}$, é descabida a posição autoritária do ente incumbido do poder de decisão. ${ }^{63}$

Odete MEDAUAR conclui que a uma concepção de homogeneidade do interesse público seguiu-se a uma situação de heterogeneidade; e de uma idéia de unicidade passou-se à concreta existência de uma multiplicidade de interesses públicos. ${ }^{64}$

As considerações dos autores apresentadas acima têm lugar diante da constatação do Estado Pluriclasse identificado por Massimo Severo GIANNINI, na contemporaneidade, para quem os interesses da esfera pública também são, hodiernamente, heterogêneos. ${ }^{65}$ Deveras, tal como afirma Sabino CASSESE, os diversos interesses públicos reproduzem, dentro da própria Administração Pública, os conflitos existentes na sociedade. $^{66}$

\footnotetext{
${ }^{59}$ Cf. Floriano de Azevedo MARQUES, Regulação Estatal e Interesses Públicos, p. 152. Alexandre Santos de ARAGÃO afirma a esse respeito que: "O interesse público e os interesses dos cidadãos, que antes eram vistos como potencialmente antagônicos, passam a ser vistos como em princípio reciprocamente identificáveis". A Supremacia do Interesse Público no Advento do Estado de Direito e na Hermenêutica do Direito Público Contemporâneo, p. 3.

${ }^{60}$ Public/Privé, p. 161.

${ }^{61}$ El Principio General de la Buena Fe en el Derecho Administrativo, p. 40.

${ }^{62}$ Renato Alessi estabeleceu distinção fundamental entre interesse público primário e secundário que passou a ser utilizada por diversos administrativistas brasileiros que estudaram o tema. De acordo com o autor italiano, interesse público primário são os interesses de toda a sociedade aos quais cumpre ao Estado promover; e interesse público secundário seria aquele da pessoa jurídica de direito público que seja parte de uma determinada relação jurídica (União, Estados, Municípios, autarquias, por exemplo). Sistema Istituzionale del Diritto Ammnistrativo Italiano, p. 197.

${ }^{63}$ Regulação Estatal e Interesses Públicos, p. 154-155.

${ }^{64}$ O Direito Administrativo em Evolução, p. 190. No mesmo sentido é o posicionamento de Floriano de Azevedo MARQUES. Regulação Estatal e Interesses Públicos.

${ }^{65}$ Diritto Amministrativo, v. 2, p. 111.

${ }^{66}$ Las Bases del Derecho Administrativo, p. 69.
} 
É, pois, tendo em vista a possível correspondência entre interesses públicos e privados que a doutrina administrativista contestadora propõe uma releitura do princípio da supremacia do interesse público sobre o interesse privado. Com efeito, a convivência de múltiplos interesses públicos e privados, por vezes coincidentes, impede a aplicação automática do referido princípio para o afastamento dos interesses dos grupos sociais. ${ }^{67}$ Conforme afirma José Eduardo FARIA, sem uma avaliação qualitativa dos interesses individuais por parte do Estado não é possível, hodiernamente, definir-se, no caso concreto, o interesse público prevalecente. ${ }^{68}$

Desta feita, a prevalência do interesse público sobre o interesse privado somente existiria após a ponderação in concreto dos elementos colidentes. ${ }^{69}$ Não haveria, portanto, supremacia ou prevalência a priori e automática, mas, apenas, a posteriori e fundamentada. $^{70}$

É, por essas razões, que adotaremos ao longo deste trabalho a expressão interesses legítimos para designar tanto interesses públicos quanto interesses privados, conviventes ou conflitantes entre si, que encontrem guarida no ordenamento jurídico pátrio e que, portanto, devem ser considerados nos processos decisórios das Agências Reguladoras e, especificamente, da ANATEL.

\footnotetext{
${ }^{67}$ Nesse sentido, Alexandre Santos de ARAGÃO ressalta que “(...) muitas vezes as lides envolvendo o Direito Público se vêem turvadas por uma genérica e mítica invocação do 'interesse público', ou de subespécies suas como 'ordem pública', 'saúde pública', 'bem-estar da coletividade', 'moral pública' etc., que, ao entrar em ponderação com quaisquer outros valores envolvidos, sempre prevaleceriam, ainda quando a Constituição ou a lei já contivessem regra específica pré-disciplinando e pré-ponderando a questão, o que é inadmissível". Assevera ainda Alexandre Santos de ARAGÃO que "[n]ao há um interesse público abstratamente considerado que deva prevalecer sobre os interesses particulares eventualmente envolvidos. A tarefa regulatória do Estado é bem mais complexa do que a singela formulação de uma 'supremacia do interesse público.'”. A Supremacia do Interesse Público no Advento do Estado de Direito e na Hermenêutica do Direito Público Contemporâneo, p.9.

${ }^{68}$ Direito e Economia na Democratização Brasileira, p. 71-72.

${ }^{69} \mathrm{O}$ Supremo Tribunal Federal (STF) já se manifestou no sentido de que "o interesse público e o interesse privado se entrelaçam de tal forma, que as mais das vezes não é possível separá-los.”. ADIN n. ${ }^{\circ}$ 493-DF.

A propósito do tema, o Superior Tribunal de Justiça (STJ) já se manifestou no sentido de reprimir os argumentos de agência reguladora que sustentavam que os interesses por ela tutelados deveriam prevalecer sobre "meros" interesses privados. In verbis: "Não se pode atribuir conotação maniqueísta e discriminatória aos interesses comerciais da empresa requerente, tão-só porque confrontados, na espécie, com os sagrados princípios que dizem o direito à vida e à saúde da população brasileira, dos quais se coloca como guardiã a Agência requerida. Por mais sensível que seja o tema, não pode o julgador partir do pressuposto de que são inconciliáveis os direitos e interesses debatidos na lide, sob pena de restar comprometida a realização da justiça.” AGRMC n. ${ }^{\circ}$ 6.146/DF. 2 2 T., Rel. Ministro João Otávio de Noronha. DJ. 29/09/2003, p. 00172.
}

${ }^{70}$ Cf. Humberto ÁVILA. Sistema Constitucional Tributário. São Paulo: Saraiva, 2004, p. 273. 
Odette MEDAUAR assevera, em conseqüência da relação renovada entre interesses públicos e privados apresentada acima, que na atualidade se impõe a modificação do entendimento de "sacrifício de um interesse em benefício de outro, ou de primazia de um sobre outro interesse. Cogita-se hoje da função atribuída à Administração de ponderação dos interesses em confronto; o princípio é da não sacrificabilidade a priori de nenhum interesse; o objetivo dessa função está na busca do estatuto da compatibilidade entre os interesses." ${ }^{71}$ (grifos nossos)

Em outras palavras, diante de múltiplos interesses legítimos em confronto, não mais se mostra adequado que, de antemão, se afirme a prevalência do interesse apontado como público pela Administração Pública ${ }^{72}$, mas que todos os interesses em jogo sejam ponderados e que o resultado dessa ponderação reflita a maior compatibilidade possível entre eles. $^{73}$

É, pois, precisamente sob esse pano de fundo que o Estado Contemporâneo se apresenta, também, como mediador de interesses legítimos contrapostos. Daí decorre a expressão Estado Mediador que pode ser encontrada na doutrina administrativista quando a intenção do autor é reforçar a função de mediação estatal no Estado Contemporâneo. ${ }^{74}$

Nas precisas palavras do grande jus filósofo Norberto BOBBIO, “a vida de um Estado Moderno, no qual a sociedade civil é constituída por grupos organizados cada vez mais fortes, está atravessada por conflitos grupais que se renovam continuamente, diante

\footnotetext{
${ }^{71}$ O Direito Administrativo em Evolução, p. 183.

${ }^{72}$ Floriano de Azevedo MARQUES afirma a esse respeito que o princípio da supremacia do interesse público “deve ser aprofundado de modo a adquirir a feição de prevalência dos interesses públicos e desdobrando-se em três subprincípios balizadores da função administrativa: (i) a interdição do atendimento de interesses particularísticos (v.g., aqueles desprovidos de amplitude coletiva, transindividual); (ii) a obrigatoriedade de ponderação de todos os interesses públicos enredados no caso específico; e (iii) a imprescindibilidade de explicitação das razões de atendimento de um interesse público em detrimento dos demais.” Regulação Estatal e Interesses Públicos, p. 165.

${ }^{73}$ No mesmo sentido é o entendimento de Massimo Severo GIANNINI. Diritto Amministrativo, p. 48-49.0 autor italiano sustenta que os interesses contraditórios devem ser conformados e ponderado entre si. Cf., também, Alexandre Santos de ARAGÃO. Agências Reguladoras e a Evolução do Direito Administrativo Econômico, p. 292. O jurista carioca assevera que as Agências Reguladoras devem buscar, dentro do mandado de otimização que lhes é inerente, a maior compatibilização possível entre os interesses em conflito.

${ }^{74}$ Odete MEDAUAR bem descreve esse processo, asseverando que o Estado deixa de deter a "exclusividade no estabelecimento do interesse público; a discricionariedade se reduz, atenua-se a prática de imposição unilateral e autoritária de decisões. A Administração volta-se para a coletividade, passando a conhecer melhor os problemas e aspirações da Sociedade. A Administração passa a ter a atividade de mediação para dirimir e compor conflitos de interesses entre as várias partes ou entre estas e a Administração. Daí decorre um novo modo de agir, não mais centrado sobre o ato como instrumento exclusivo de definição do interesse público, mas como atividade aberta à colaboração dos indivíduos. Passa a ter relevo o momento do consenso e da participação.” Direito Administrativo em Evolução, p. 202.
} 
dos quais o Estado, como conjunto de organismos de decisão (Parlamento e Governo) e de execução (o aparato burocrático), desenvolve a função de mediador e garante mais do que detentor do poder de império segundo a representação clássica da soberania." 75

Conferindo contornos a esse processo, Odete MEDAUAR assevera que o Estado deixa de deter a "exclusividade no estabelecimento do interesse público; a discricionariedade se reduz, atenua-se a prática de imposição unilateral e autoritária de decisões. A Administração volta-se para a coletividade, passando a conhecer melhor os problemas e aspirações da Sociedade. A Administração passa a ter a atividade de mediação para dirimir e compor conflitos de interesses entre as várias partes ou entre estas e a Administração. Daí decorre um novo modo de agir, não mais centrado sobre o ato como instrumento exclusivo de definição do interesse público, mas como atividade aberta à colaboração dos indivíduos. Passa a ter relevo o momento do consenso e da participação." 76

A Administração Pública autoritária dá lugar, assim, paulatinamente, à administração consensual ${ }^{77}$ na qual o papel de ponderação dos interesses legítimos contrapostos dos administrados se apresenta como de fundamental relevância. ${ }^{78}$

Antes de prosseguirmos, cumpre esclarecer, pois, nesse contexto, outro ponto de fundamental importância para a presente dissertação de mestrado, nossa opção por designar o processo de sopesamento e valoração dos interesses legítimos em conflito pelo Estado Mediador, no âmbito regulatório, como mediação ativa.

\footnotetext{
${ }^{75}$ Estado, Governo e Sociedade, p. 26.

${ }_{77}^{76}$ Direito Administrativo em Evolução, p. 202.

${ }^{77}$ Sobre o tema ver Atuação Administrativa Consensual de Juliana Bonacorsi de PALMA. Dissertação de Mestrado apresentada à Faculdade de Direito do Largo São Francisco da Universidade de São Paulo, 2010. Ver também Novos Institutos Consensuais da Ação Administrativa. Diogo de Figueiredo MOREIRA NETO. Revista de Direito Administrativo - RDA. Rio de Janeiro: Fundação Getúlio Vargas, vol. 231, 2003, p. 129-156. O jurista carioca registra, ainda, as vantagens da administração consensual, quais sejam: respostas mais eficientes, mais rápidas, de menos custos e mais legitimadas. Prefácio à obra de Marcos Juruena Villela Souto. Aspectos Jurídicos do Planejamento Econômico, p. 3-4.

${ }^{78}$ Gustavo Justino de OLIVEIRA esclarece a esse respeito que: "Tarefas do Estado mediador passam a ser, não somente as de estabelecer e conferir eficácia aos canais de participação e de interlocução com os indivíduos e grupos sociais, mas a de com eles constantemente interagir, instituindo e mantendo vínculos robustos e duradouros. Tais vínculos são tidos hodiernamente como indispensáveis a atribuição de eficácia e de efetividade em espaços de forte interseção entre Estado e sociedade civil, esferas em processo contínuo de recíproca interpenetração. Ademais disso,cabe notar que a principal tarefa da Administração mediadora passa a ser a de compor conflitos envolvendo interesses estatais e interesses privados, definitivamente incluindo os cidadãos no processo de determinação do interesse público, o qual deixa de ser visto como um monopólio estatal, com participação exclusiva de autoridades, órgãos e entidades públicos, e passa a ser compreendido como resultado de processos de harmonização e de ponderação de diversos interesses públicos, interesses privados e interesses das organizações da sociedade civil.”. Governança Pública e Parcerias do Estado: a relevância dos acordos administrativos para a nova gestão pública, p. 137-138.
} 
Vimos nas passagens acima que a desconstrução ou a releitura do princípio da supremacia do interesse público sobre o privado acarreta à Administração Pública o dever de ponderação dos interesses legítimos contrapostos em cada caso concreto. É esse processo que permitirá à autoridade pública identificar qual é a ordem e a intensidade da prevalência entre os interesses em embate e a medida de compatibilização ou de sacrifício entre eles.

Esse processo não é identificado na doutrina administrativista, entretanto, apenas por ponderação, mas também por sopesamento, arbitramento e mediação, todos esses termos são utilizados como sinônimos à ponderação, na acepção descrita acima.

Floriano de Azevedo MARQUES, particularmente, cunhou o conceito de mediação ativa de interesses. ${ }^{79}$ Analisando a intervenção regulatória na ordem econômica e as suas peculiaridades em relação às demais formas de intervenção estatal na economia, o autor, observou que estas diferem nos seus pressupostos porque a intervenção regulatória é muito mais pautada pelo caráter de mediação do que pela imposição de objetivos e comportamentos ditada pela autoridade pública. O autor assevera, ainda, que a regulação deve favorecer não a imposição de pautas regulatórias, mas a busca do consenso e da mediação de interesses, sem perder de vista a tutela dos interesses gerais da sociedade.

A mediação ativa de interesses é assim explicada pelo autor:

“11. A noção de atividade regulatória numa perspectiva de 'mediação ativa de interesses' envolve uma dupla atividade estatal. De um lado, o regulador tem de arbitrar interesses de atores sociais e econômicos fortes (...). Doutro bordo, cumpre ao regulador induzir ou coordenar as atividades em cada segmento específico com vistas a proteger $e$ implementar interesses de atores hipossuficientes. É o que tem lugar na defesa dos consumidores ou no atendimento das políticas públicas.O equilíbrio entre estas duas vertentes da moderna atividade regulatória (acima denominada como 'mediação ativa de interesses' faz com que o Estado, enquanto regulador, não seja apenas um mediador passivo das relações sociais (o que remeteria o Estado a uma

\footnotetext{
${ }^{79}$ Agências Reguladoras Independentes - Fundamentos e seu Regime Jurídico, p. 31 e 50.
} 
posição de mero árbitro, impotente e meramente reativo, dos interesses hipossuficientes, um singelo 'bedel do mercado'). Porém, implica em uma atuação ativa marcadamente subsidiária, na qual a consagração de metas devem ser estabelecidas a partir das possibilidades de cada setor da economia e não definida unilateral $e$ exclusivamente a partir dos espaços decisórios estatais." 80 (grifos nossos)

Considerando, pois, o foco na regulação estatal e, bem assim, o caráter próativo (e não meramente reativo) e o realce da tutela dos interesses hipossuficientes pelo regulador, optamos, neste trabalho, por adotar a expressão mediação ativa de interesses, para designar as situações em que a autoridade regulatória deve ponderar e valorar todos os interesses em jogo, diante do caso concreto, buscando a melhor solução juridicamente possível. $^{81}$

A mediação ativa de interesses pressupõe impreterivelmente o manejo de alguma discricionariedade pelas autoridades públicas e, logo, pelo regulador.

Identificados, assim, em concreto, múltiplos interesses legítimos contrapostos e descabida a posição autoritária do regulador para a prévia indicação do interesse prevalecente, a definição da satisfação ou do sacrifício de um ou de outro interesse e a intensidade dessa relação, passa a depender, cada vez mais, do exercício da discricionariedade nos processos decisórios.

Nesse sentido, asseverou Massimo Severo GIANNINI que “o momento essencial da discricionariedade é aquele no qual se individualizam e confrontam os vários interesses concorrentes." 82

A pluralidade de interesses legítimos em confronto e o dever estatal de mediação destes interesses importam, nessa medida, no incremento da discricionariedade do regulador, já acentuada no campo da regulação da atividade econômica.

\footnotetext{
${ }^{80}$ A Nova Regulação dos Serviços Públicos, p. 17.

${ }^{81}$ Esse conceito é apresentado e desenvolvido na PARTE III deste trabalho, Capítulos IV e V.

${ }^{82}$ Il Potere Discrezionale della Pubblica Amministrazione, p. 75.
} 
A esse acréscimo das margens de ação do regulador na mediação ativa de interesses legítimos deve corresponder, necessariamente, o reforço dos instrumentos de controle das decisões regulatórias discricionárias ${ }^{83}$, se não se as quer arbitrárias. ${ }^{84}$

É que, nesse cenário, a discricionariedade do regulador deve ser compreendida como uma liberdade-vínculo, como anota Odete MEDAUAR, isto é, como um poder-dever (ou dever-poder, como veremos no Capítulo II) de representar todos os fatos e de levar em conta todos os interesses envolvidos no caso concreto, atribuindo-lhes um justo peso ${ }^{85}$; passa, então, a ser de extrema relevância não apenas a decisão regulatória discricionária, mas todo o seu processo de formativo.

É dizer, assim, que o incremento do controle das decisões regulatórias discricionárias deve compreender todo o processo decisório e não apenas o seu ato final. Mais que isso, é preciso que existam parâmetros objetivos e concretos que permitam o acompanhamento e confronto de todas as etapas de formação das decisões regulatórias discricionárias. Sem esse ferramental, a ampla discricionariedade do regulador para o apontamento de perdedores e vencedores nos setores regulados submete os seus agentes ao real risco de arbitrariedades. É no que trabalharemos no Capítulo V.

\section{I.3. 2. A Discricionariedade e a Juridicidade.}

Outra noção basilar que permeia esse trabalho é a de vinculação da discricionariedade da autoridade pública e, pois do regulador, à juridicidade e não mais à legalidade, em sentido estrito. A juridicidade, como veremos, por um lado, amplia o espaço de discricionariedade do regulador e, por outro lado, incrementa os limites de seu controle.

A doutrina administrativista, há muito, reconhece a centralidade do princípio da legalidade para o Direito Público contemporâneo. ${ }^{86}$

${ }^{83}$ Cf. Floriano de Azevedo MARQUES. Discricionariedade Administrativa e Controle Judicial da Administração, p. 195.

${ }^{84}$ Sobre o tema, confira-se: Sérgio GUERRA. O Controle Judicial dos Atos Regulatórios.

${ }^{85}$ O Direito Administrativo em Evolução, p. 196-197.

${ }^{86}$ Cf. Floriano de Azevedo MARQUES. Discricionariedade Administrativa e Controle Judicial da Administração, p. 192. Celso Antonio BANDEIRA DE MELLO afirma que é o princípio da legalidade é o princípio capital para a configuração do regime jurídico-administrativo. Curso de Direito Administrativo, p. 101. 
A sua angular importância remete-nos às bases do Estado Democrático de Direito e encerra a idéia de que a atividade administrativa é absolutamente vinculada à Lei. $^{87}$

Carlos Ari SUNDFELD, assim, sintetiza a concepção originária de vinculação da Administração Pública à Lei:

"A atividade administrativa deve ser desenvolvida nos termos da lei. A Administração só pode fazer o que a lei autoriza: todo ato seu há de ter base em lei, sob pena de invalidade. Resulta daí uma clara hierarquia entre a lei e o ato da Administração Pública: este se encontra em relação de subordinação necessária àquela. Inexiste poder para a Administração Pública que não seja concedido pela lei: o que a lei não lhe concede expressamente, nega-lhe implicitamente. Todo poder é da lei; apenas em nome da lei se pode impor obediência. Por isso, os agentes administrativos não dispõem de liberdade - existente somente para os indivíduos considerados como tais -, mas de competências, hauridas e limitadas na lei." 88

Desenvolveu-se, nesse sentido, a concepção clássica de que a discricionariedade da Administração Pública teria sua fonte e direção exclusivamente na Lei, razão pela qual se lhe batizou como legalidade estrita. É dizer que as escolhas públicas seriam legitimas desde que, e apenas se, conformadas com a Lei. ${ }^{89}$

Diversas transformações no Estado e na sociedade - e na relação entre eles -, entretanto, impulsionaram o que parte da doutrina administrativista denominou como crise

\footnotetext{
${ }^{87}$ Gustavo BINEMBOJM observa que se trata do princípio da vinculação administrativa à legalidade, entendido classicamente como vinculação positiva à Lei. Uma Teoria do Direito Administrativo, p. 126.

${ }_{88}^{88}$ Fundamentos de Direito Público, p. 159.

${ }^{89}$ Maria Sylvia Zanella DI PIETRO assevera a esse respeito que "a discricionariedade implica liberdade de a atuação nos limites traçados pela lei; se a Administração ultrapassar esses limites, sua decisão para a ser arbitrária." Discricionariedade Administrativa na Constituição de 1988, p. 67. A autora, ainda, bem desenvolve, ao longo dos tempos, a relação entre legalidade e discricionariedade. Vale a pena conhecer, na mesma obra, p. 17-65.
} 
do princípio da legalidade, melhor identificada por Floriano de Azevedo MARQUES como crise da própria noção de Lei. ${ }^{90}$

Gustavo BINEMBOM enumerou cinco razões básicas da crise da lei ${ }^{91}$ em geral e da legalidade administrativa: (i) a proliferação ou inflação legislativa, (ii) a constatação de que a Lei pode fundamentar injustiças e barbáries, (iii) a substituição da Lei pela Constituição como a mais importante forma de expressão da vontade geral. (iv) a proliferação de atos normativos infraconstitucionais, e (v) a expansão das atribuições normativas do Executivo. ${ }^{92}$

Como conseqüência, difundiu-se a idéia de vinculação da Administração Pública aos ordenamentos jurídicos como um todo, isto é, a todo o sistema de normas regente dos $\operatorname{Estados}^{93}$, com destaque às Leis Maiores, as Constituições.

Assumiu-se, assim, paulatinamente, que a vinculação da Administração Pública não seria apenas à Lei, mas a um bloco de legalidade (o sistema de normas) a que aludia Maurice HAURIOU. ${ }^{94}$

A essa ampla vinculação da Administração Pública aos ordenamentos jurídicos nacionais, Adolfo MERKL denominou princípio da juridicidade ${ }^{95}$, expressão que se difundiu internacionalmente. Mas, foi Paulo OTERO ${ }^{96}$ quem dedicou amplo e profundo estudo de ao tema.

\footnotetext{
${ }^{90}$ Discricionariedade Administrativa e Controle Judicial da Administração, p. 192. No mesmo sentido é o entendimento de Odete MEDAUAR. O Direito Administrativo em Evolução, p. 146.

$91 \mathrm{O}$ autor refere-se à crise da Lei em seu sentido formal e não material. Uma Teoria do Direito Administrativo, p. 126.

92 Uma Teoria do Direito Administrativo, p. 127-136. Em sentido próximo, Odete MEDAUAR. O Direito Administrativo em Evolução, p. 145 e ss. Nesse contexto, insere-se, também, a produção dos ordenamentos administrativos setoriais em decorrência de uma Administração Pública Policêntrica. Sobre o tema ver, por todos, Alexandre Santos de ARAGÃO. Ordenamentos Setoriais e as Agências Reguladoras.

${ }^{93}$ Gustavo BINEMBOJM assim explica essa passagem asseverando que a idéia de vinculação negativa à lei mostrou-se inadequada ao Estado - sendo suficiente apenas para reger a vida dos particulares - já que este existe apenas para realizar as finalidades que lhe forem ditadas pela sociedade. Assim, tornou-se necessária a subordinação do Estado ao ordenamento jurídico, "não apenas como um limite externo, mas também como uma condição ou fundamento da ação estatal.”. E, continua o autor: “Com efeito, a vinculação da atividade administrativa ao direito não obedece a um esquema único nem se reduz a um tipo específico de norma jurídica - a lei formal. Essa vinculação, ao revés, dá-se em relação ao ordenamento jurídico como uma unidade (Constituição, leis, regulamentos gerais, regulamentos setoriais), expressando-se em diferentes graus e distintos tipos de normas, conforme a disciplina estabelecida na matriz constitucional." Uma Teoria do Direito Administrativo, p. 140-141.

${ }^{94}$ Cf. Louis FAVOREU. El Bloque de la Constitucionalidad, p. 20.

${ }^{95}$ Nas palavras do autor: "la conexión necesaria entre derecho y administración puede ser designada como principio de la juridicidad de la administración”. Teoría General de Derecho Administrativo, p. 206.

${ }^{96}$ Legalidade e Administração Pública: O Sentido da Vinculação Administrativa à Juridicidade.
} 
O autor português, já nas primeiras linhas de sua obra, explica o conteúdo da juridicidade, em passagem imperdível:

"A juridicidade traduz uma legalidade mais exigente, revelando que o poder público não está apenas limitado pelo Direito que cria, encontrando-se também condicionado por normas e princípios cuja existência e respectiva força vinculativa não se encontram na disponibilidade desse mesmo poder. Neste sentido, a vinculação administrativa à lei transformou-se numa verdadeira vinculação ao Direito, registrando-se aqui o abandono de uma concepção positivista-legalista configurativa da legalidade administrativa (...) o princípio da legalidade administrativa se converteu em princípio da juridicidade, expressando um modelo de Administração Pública sujeita ao Direito, falando-se em Estado de juridicidade e reconhecendo o Direito, neste preciso sentido, uma função de protecção dos cidadãos contra a prepotência, o arbitrio e a injustiça do poder (...). ${ }^{97}$ (grifos nossos)

A idéia de vinculação da Administração Pública ao Direito e não meramente à Lei, marca a superação do positivismo legalista e demarca novos limites de atuação e controle das autoridades públicas.

Alexandre Santos de ARAGÃO, ao tratar da concepção pós-positivista do princípio da legalidade, assim, fotografou esse processo:

"Com efeito,evoluiu-se para se considerar a Administração Pública vinculada não apenas à lei, mas a todo um bloco de legalidade, que incorpora os valores, princípios e objetivos jurídicos maiores da sociedade, com diversas Constituições (por exemplo, a alemã e a espanhola) passando a submeter a Administração Pública expressamente à "lei $e$ ao Direito”, o que também se infere implicitamente da nossa Constituição e expressamente da Lei de Processo Administrativo Federal (art. $2^{\circ}$, Parágrafo único, I). A esta

\footnotetext{
${ }^{97}$ Legalidade e Administração Pública: O Sentido da Vinculação Administrativa à Juridicidade, p. 15,
} NR 1. 
formulação dá-se o nome de Princípio da Juridicidade ou da legalidade em sentido amplo". ${ }^{9}$

Com esse registro o autor ressalta o elemento constitucional no princípio da juridicidade. Com efeito, as Constituições - conquanto nortes interpretativos de todos os ordenamentos nacionais - passam a vincular diretamente as Administrações Públicas. ${ }^{99}$ Esse fenômeno é, pois, identificado como a constitucionalização do Direito Administrativo, ramo do Direito que cuida da Administração Pública. ${ }^{100}$

O autor, ainda, ilustra a título exemplificativo, que as Constituições Alemã e Espanhola apresentam dispositivos que explicitam a vinculação da Administração Pública não só a Lei, mas ao Direito. Odete MEDAUAR destaca, a esse respeito, que a extensão da legalidade, mediante a vinculação da atividade administrativa a valores consagrados constitucionalmente e no próprio modelo de Estado Social e Democrático de Direito transparece nas Constituições mais antigas, como a Portuguesa e a Espanhola. ${ }^{101}$

No Brasil, a autora considera que se deve compreender o princípio da legalidade enunciado no art. 37, caput, da Constituição Federal, não só como uma vinculação à Lei formal, mas também aos preceitos decorrentes do Estado Democrático de Direito nacional, conforme previsto no art. $1^{\circ}$, caput, da Constituição Federal e, ainda, incluir os demais fundamentos e princípios de base constitucional. "Desse modo vincula-se a atividade administrativa aos valores que informam o ordenamento como um todo, associando-se, de modo mais estreito, o direito administrativo ás disposições constitucionais.” 102

\footnotetext{
${ }^{98}$ A Concepção Pós-Positivista do Princípio da Legalidade, p. 63.

99 Paulo OTERO assim explicou a substituição da Lei pela Constituição no comando das ações da Administração Pública: "Encontra-se aqui exposta, por conseguinte, uma via de rotura do mito da omnipotência da lei face à Administração Pública e da consequente menoridade ou inferioridade da Constituição perante a lei no âmbito da função administrativa: em vez da eficácia operativa das normas constitucionais estar sempre dependente da lei na sua vinculatividade para a Administração Pública, tal como se encontra subjacente ao pensamento liberal oitocentista, a lei deixou de ter hoje o monopólio habilitante da atividade administrativa, registrando-se que a aplicação da Constituição à Administração Pública não exige necessariamente a mediação legislativa.”. Legalidade e Administração Pública: O Sentido da Vinculação Administrativa à Juridicidade, p. 735.

${ }^{100}$ Luís Roberto BARROSO ao tratar da constitucionalização do Direito Administrativo bem demonstra a necessidade de superação da idéia de legalidade, em sentido estrito, como vinculação positiva da autoridade pública à lei pela juridicidade. Apontamentos sobre o Princípio da Legalidade, p. 32. Sobre o tema ver: A Nova Interpretação Constitucional (Ponderação, Direitos Fundamentais e Relações Privadas). Luís Roberto BARROSO (Org.) e A Constitucionalização do Direito. Virgílio AFONSO DA SILVA.

${ }^{101}$ O Direito Administrativo em Evolução, p. 148-149.

${ }^{102}$ O Direito Administrativo em Evolução, p. 149.
} 
Decorre da juridicidade, ainda, importante formulação que desconstrói a fixa barreira entre atos vinculados e atos discricionários, cara à doutrina administrativista clássica e que, por décadas, tem sido utilizada para explicar o próprio conceito de discricionariedade.

Trata-se da teoria dos graus de vinculação dos atos administrativos, segundo a qual o universo de atos administrativos não está representado na dicotomia: atos vinculados e atos discricionários. Em outras palavras, não existiriam atos administrativos exclusivamente vinculados ou exclusivamente discricionários, mas graus de vinculação dos atos administrativos; de modo que, de alguma forma, todos os atos administrativos apresentam alguma vinculação e alguma discricionariedade. ${ }^{103}$ Não há, nessa medida, espaço decisório para a Administração Pública alheio ao Direito, tampouco, margem decisória imune aos princípios constitucionais.

A noção de discricionariedade com o sentido de margem de liberdade está, assim, cada vez mais afastada, uma vez que toda e qualquer atividade administrativa, em maior ou menor grau, estará atrelada a peias vinculantes.

A vinculação da atividade administrativa ao ordenamento jurídico é, portanto, uma via de mão dupla: serve tanto para restringir as ações da Administração Pública, como também para permitir a sua atuação quando, mesmo diante da ausência de lei infraconstitucional específica, os valores da Constituição impuserem a sua atuação. ${ }^{104}$

Assim, se por um lado, ampliam-se as margens discricionárias para a atuação da Administração Pública, por outro lado, incrementam-se os limites de controle dessa discricionariedade expandida.

\footnotetext{
${ }^{103}$ Cf. Gustavo BINEMBOJM. Uma Teoria do Direito Administrativo, p. 212.

${ }^{104}$ Cf. Alexandre Santos de ARAGÃO. A Concepção Pós-Positivista do Princípio da Legalidade, p. 63. Cf. também, Humberto ÁVILA Teoria dos Princípios. E, cf. Gustavo BINEMBOJM. Uma Teoria do Direito Administrativo, p. 142. Este último, assim, explica seu posicionamento: “A idéia de juridicidade administrativa, elaborada a partir da interpretação dos princípios e regras constitucionais, passa, destarte, a englobar o campo da legalidade administrativa, como um doe seus princípios internos, mas não mais altaneiro e soberano como outrora. Isso significa que a atividade administrativa continua a realizar-se, via de regra: (i) segundo a lei, quando esta for constitucional (atividade secundum legem), (ii) mas pode encontrar fundamento direto na Constituição, independentemente ou para além da lei (praeter legem), ou eventualmente, (iii) legitimar-se perante o direito, ainda que contra a lei, porém com fulcro numa ponderação da legalidade com outros princípios constitucionais (atividade contra legem, mas com fundamento numa otimizada aplicação da Constituição).” Ressalve-se, entretanto, que não há consenso na doutrina administrativista acerca desta última possibilidade anotada por Gustavo BINEMBOJM.
} 
Tal incremento dá-se, principalmente, por meio da aplicação dos Princípios Gerais de Direito - como vimos, no item I.3 deste Capítulo, invocados largamente pela doutrina administrativista para esse fim - e dos princípios basilares do próprio Estado Democrático de Direito.

Entendemos, todavia, como demonstraremos na PARTE III desta dissertação de mestrado, que a utilização do referido novel principiológico para a confrontação das decisões administrativas discricionárias, especialmente as regulatórias, não é suficiente, em razão da sua abstração e, pois, da subjetividade que é inerente a sua aplicação; razão pela qual propomos parâmetros concretos e objetivos para essa finalidade.

\section{I.3. 3. A Discricionariedade e a Policentrismo Estatal.}

A descentralização estatal em diversos pólos de decisão é um dos fenômenos que marca o período que identificamos inicialmente como pó-modernidade.

É, nesse período, que se difunde a idéia de uma Administração Pública policêntrica e insulada de influências políticas, caracterizada por sua expertise e pela sua capacidade de responder pronta e eficientemente às demandas crescentes de uma sociedade cada vez mais complexa. ${ }^{105}$

Paulo OTERO, assim, registrou as causas do movimento de descentralização estatal:

"O progressivo alargamento das tarefas a cargo do Estado resultando de um crescente intervencionismo econômico $e$ social que viria a ser transformado em cumprimento de imperativos constitucionais implementadores de cláusulas de bem-estar ou de Estado social, determinou a insuficiência do aparelho do Estado na satisfação pessoal e directa de todas as necessidades coletivas a seu cargo e a conseqüente multiplicação de estruturas orgânicas de decisão. $O$ descongestionamento de tarefas estaduais e, neste contexto,

${ }^{105}$ Cf. Gustavo BINEMBOJM. Agências Reguladoras Independentes e Democracia no Brasil, p. 2. 
a descentralização tornaram-se inevitáveis no Estado de bem-estar." 106

Nesse contexto, continua o jurista português, “o Estado perdeu o monopólio do exercício da função administrativa, assistindo-se a uma divisão interna do exercício do poder administrativo entre diferentes entidades públicas: o pluralismo organizativo é uma realidade inerente ao modelo administrativo vigente num Estado de Direito democrático”. E conclui: "Não existe hoje, por conseguinte, uma única Administração Pública mas várias Administrações Públicas.” (grifos nossos)

Essas transformações no modelo de organização administrativa deram ensejo, dentre outros entes públicos e privados ${ }^{107}$, ao surgimento e à proliferação das Agências Reguladoras, substituindo-se a idéia de unidade da Administração Pública pela noção de uma Administração Policêntrica.

Gustavo BINEMBOJM explica, a esse respeito, que as Agências Reguladoras, entes dotados de autonomia reforçada, romperam com a tradicional organização administrativa piramidal, em que a unidade estrutural era alcançada pela responsividade imediata de todos os órgãos e entes administrativos à política governamental. Nas palavras do autor:

\begin{abstract}
"As autoridades ou agências independentes quebraram o vínculo de unidade no interior da Administração Pública, eis que a sua atividade passou a situar-se em esfera jurídica externa à da responsabilidade política do governo. Caracterizadas por um grau reforçado da autonomia política de seus dirigentes em relação à chefia da Administração central, as autoridades independentes rompem o modelo tradicional de recondução direta de todas as ações administrativas ao governo (decorrente da unidade
\end{abstract}

\footnotetext{
${ }^{106}$ Legalidade e Administração Pública: O Sentido da Vinculação Administrativa à Juridicidade, p. 148.

107 Alexandre Santos de ARAGÃO destaca a proliferação de diversos grupos ou centros de poder nesse período. Nas palavras do autor: "Não há como negar que hoje temos vários grupos ou centros de poder, públicos, semipúblicos ou privados, dotados de autonomia, atuando dentre ou paralelamente à estrutura do Estado, levando ao franco declínio o modelo de organização centralizado surgido com a modernidade." Agências Reguladoras e a Evolução do Direito Administrativo Econômico, p. 183.
} 
da Administração). Passa-se, assim, de um desenho piramidal para uma configuração policêntrica." 108

As Agências Reguladoras constituem, portanto, dentro da nova configuração de organização administrativa estatal, pólos de decisão autônomos incumbidos da regulação dos mais diversos setores da economia. ${ }^{109}$

Dotadas de uma ampla gama de competências associadas a uma alta especialização técnica, de modo a intervir em um determinado setor da economia, as Agências Reguladoras detém um extenso rol de poderes, que constituem o seu ferramental para o cumprimento das atribuições que lhe são conferidas por lei. ${ }^{110}$

É inerente, ainda, à regulação econômica, conforme anota Floriano de Azevedo MARQUES, a conferência pelo legislador de margens razoavelmente amplas de discricionariedade às Agências Reguladoras para, em cada situação concreta, decidir qual é a solução mais adequada e conformada com o equilíbrio do sistema regulado. ${ }^{111}$

Desta feita, as Agências Reguladoras constituem, em última análise, pólos autônomos de decisão discricionária em setores específicos, tal como a ANATEL no setor de telecomunicações, como veremos no Capítulo III. ${ }^{112}$

Esse registro torna-se ainda mais relevante diante da constatação - que fizemos no item III. 1. acima - de que cumpre às Agências Reguladoras a mediação ativa de interesses legítimos contrapostos nos setores de suas competências, o que implica, impreterivelmente, no manejo de alguma discricionariedade.

108 A Constitucionalização do Direito Administrativo no Brasil: Um Inventário de Avanços e Retrocessos, p. 5.

${ }^{109}$ Floriano de Azevedo MARQUES assevera que as Agências Reguladoras constituíram os instrumentos a viabilizar a intervenção estatal na ordem econômica de maneira indireta. Agências Reguladoras Independentes, p.45.

110 Destacam-se os poderes normativo, de outorga, de fiscalização, sancionatório, de conciliação e de recomendação. Cf. Floriano de Azevedo MARQUES. Agências Reguladoras Independentes p. 60-61.

111 Não obstante, o autor registra, ainda, que no cenário de moderna regulação, a discricionariedade do regulador é menor do que aquela tradicionalmente conferida aos demais órgãos administrativos porque as suas competências vem melhor definidas nas leis que instituem as Agências Reguladoras e porque ao editar normas gerais o regulador a essas se vincula. Discricionariedade e Regulação Setorial - O Caso do Controle dos Atos de Concentração por Regulador Setorial, p. 569 e ss.

${ }^{112}$ Por óbvio, também, proferem decisões vinculados, o realce às decisões discricionárias faz-se em função do objeto deste trabalho. 


\section{I.4. Conclusões.}

Ao longo deste capítulo procuramos demonstrar que, em conseqüência de transformações das mais variadas ordens no Estado e na sociedade - refletidas no Direito, a discricionariedade administrativa apresenta-se, contemporaneamente, alargada.

Referido alargamento deve-se, como vimos, especialmente à pluralidade de interesses legítimos contrapostos a demandar a mediação ativa do regulador e à juridicidade que ampliou as suas margens de atuação.

Corresponde diretamente à ampliação da discricionariedade administrativa o risco do cometimento de arbitrariedades por parte das autoridades públicas e, pois, do regulador. Revela-se, assim, de extrema relevância conhecer as razões de decisão e os parâmetros em que se fundamentam as decisões regulatórias discricionárias. Esses temas são abordados na PARTE II seguinte, respectivamente, no Capítulo II e no Capítulo III. 
PARTE II - DISCRICIONARIEDADE E ARBITRARIEDADE 


\section{NOTA PRELIMINAR}

Contextualizada a presente dissertação, pois, no Capítulo I, em um cenário de ampla e difundida discricionariedade em diversas frentes de atuação estatal, identificado o momento de profusão de múltiplos interesses legítimos contrapostos na complexa sociedade contemporânea e, assim, o dever de mediação ativa desses interesses pela Administração Pública e apontada a relação renovada e estendida entre discricionariedade e legalidade para os bordes da juridicidade, no âmbito de uma Administração Pública policêntrica.

Presta-se a PARTE II dessa dissertação a abordar as consequências do mau uso da discricionariedade pelas autoridades públicas, pontuando, pois, o risco do arbítrio, do desvio de poder e da captura do regulador (CAPÍTULO II) e a apresentar estudo de casos da Agência Nacional de Telecomunicações - ANATEL, relativos à transferência de controle de operadoras de serviços de telecomunicações, com vistas a demonstrar concretamente a fragilidade e a hiposuficiência dos regulados em face de decisões discricionárias desparametrizadas das Agências Reguladoras e a dificuldade, senão impossibilidade, por ausência de critérios objetivos, de seu acompanhamento e controle por parte dos interessados e dos órgãos de fiscalização (CAPÍTULO III).

Não pretendemos criticar especificamente qualquer ato do regulador. Mas analisar como a discricionariedade, no exemplo da ANATEL, pode ser desviada e como podermos aperfeiçoar seu emprego. 


\section{CAPÍTULO II - DISCRICIONARIEDADE versus ARBITRARIEDADE}

\section{1. Introdução.}

Discricionariedade e arbitrariedade não se confundem, muito pelo contrário, são institutos que se opõem e revelam facetas distintas de um mesmo agir administrativo.

A arbitrariedade é a discricionariedade desvirtuada. A discricionariedade arraigada no subjetivismo da autoridade pública e sem parâmetros objetivos juridicamente a essa oponíveis converte-se em arbitrariedade. ${ }^{113}$

O problema está, em última análise, nos limites do exercício da discricionariedade pela autoridade pública ${ }^{114}$.

O discricionarismo da Administração Pública não vai ao ponto de encobrir arbitrariedade, capricho, má-fé ou imoralidade administrativa. ${ }^{115}$

Este capítulo tratará, assim, do desvirtuamento da discricionariedade em arbitrariedade.

Não é possível, entretanto, tratarmos da arbitrariedade da Administração Pública, especificamente nas formas do desvio de poder da autoridade pública e da captura do regulador sem passar, ainda que de maneira breve, pelo tema da função administrativa. É por onde começamos.

\section{2. Função Administrativa.}

Dentre as primeiras lições de Direito Público encontra-se a noção de Estado de Direito, conquanto um Estado subsumido à ordem jurídica em todas as suas atividades. ${ }^{116}$

${ }^{113}$ Maria Sylvia Zanella DI PIETRO afirma, nesse sentido, que: "A arbitrariedade coloca-se do outro lado da linha que demarca o limite da discricionariedade. Aquela é a liberdade de ação que ultrapassa os limites da lei; esta é a liberdade de ação exercida nos limites da lei.". Discricionariedade Administrativa na Constituição de 1988, p. 67.

${ }^{114}$ Cf. Afonso Rodrigues QUEIRÓ. A Teoria do Desvio de Poder em Direito Administrativo. Boletim da Faculdade de Direito da Universidade de Coimbra. Coimbra, suplemento ao vol. XVI, 1942, p. 41-78. O autor produziu ainda outro artigo em que a problemática dos limites da discricionariedade é muito bem apresentada. Trata-se de A Teoria do Desvio de Poder em Direito Administrativo em que Afonso Rodrigues Queiró aprofundou a temática abordada em seu primeiro artigo sobre o tema. Revista de Direito Administrativo - RDA. Rio de Janeiro: Fundação Getúlio Vargas, v. 7, 1947, p. 52 a 80.

${ }^{115}$ Cf. Hely Lopes MEIRELLES. Direito Administrativo Brasileiro, p. 103. 
É dizer que as atividades administrativas devem desenvolver-se estritamente nos termos da Lei, a qual se encontram absolutamente subordinadas. ${ }^{117}$

Carlos Ari SUNDFELD anota que o Estado se coloca, então, sob a ordem jurídica, nos mais diversos aspectos de sua atividade e acentua:

"A atividade administrativa deve ser desenvolvida nos termos da lei. A Administração só pode fazer o que a lei autoriza: todo ato seu há de ter base em lei, sob pena de invalidade. Resulta daí uma clara hierarquia entre a lei e o ato da Administração Pública: este se encontra em relação de subordinação necessária àquela. Inexiste poder para a Administração Pública que não seja concedido pela lei: o que a lei não the concede expressamente, nega-lhe implicitamente. $\underline{\text { Todo }}$ poder é da lei; apenas em nome da lei se pode impor obediência. Por isso, os agentes administrativos não dispõem de liberdade - existente somente para os indivíduos considerados como tais -, mas de competências, hauridas e limitadas na lei." ${ }^{118}$ (grifos nossos)

\footnotetext{
${ }^{116}$ Fausto CUOCOLO anota a esse respeito que: "Stato di diritto è quello nel quale non solo ogni autorità è subordinatá al diritto, ma il diritto há determinati contenuti, riconoscendosi ai cittadini Le libertà civili e diritti publlici subiettivi esperibili e tutelabili giurisdizionakmente anche nei confronti delo Stato." Istituzioni di Diritto Publlicop. 92.

Celso Antonio BANDEIRA DE MELLO observa que: "No Estado de Direito quer-se o governo das leis e não o governo dos homens, consoante a clássica assertiva proveniente do Direito inglês. Isto significa que é ao Poder Legislativo que assiste o encargo de traçar os objetivos públicos a serem perseguidos e de fixar os meiose os modos pelos quais hão de ser buscados, competindo à Administração, por seus agentes, o mister, o dever, de cumprir dócil e fielmente os desiderata legais, segundo os termos estabelecidos em lei. Assim, a atividade administrativa encontra na lei tanto seus fundamentos quanto seus limites." Discricionariedade e Controle Jurisdicional, p. 49.

${ }^{117}$ Celso Antonio BANDEIRA DE MELLO afirma nesse sentido que: "Com efeito, existe entre a atividade administrativa e a lei uma relação de subordinação, isto é, de "sub-ordenação", ordenação inferior. Essa subordinação, nô-lo diz Renato Alessi, em observação certeira, apresenta-se sob duplo aspecto. De um lado, realça-se seu sentido positivo, querendo significar que a lei tanto pode erigir vedações à Administração, quanto impor-lhe a busca de certos fins propostos como obrigatórios; de outro lado, acentua-se um sentido negativo, ainda mais importante, qual seja: o de que a Administração não pode fazer senão o que de antemão the seja permitido por uma regra legal.” Discricionariedade e Controle Jurisdicional, p. 49.

${ }^{118}$ Fundamentos de Direito Público, p. 159.
} 
Em outras palavras, as autoridades públicas não podem dispor livremente do poder que lhes é conferido por Lei, ao contrário, devem exercê-lo exclusivamente para o cumprimento das atribuições que, também por Lei, lhes foram fixadas. ${ }^{119}$

As atividades administrativas devem, pois, ser realizadas com vistas ao atingimento dos fins previamente definidos em Lei. É que, como já observara oportunamente Ruy Cirne LIMA, “[o] fim - e não a vontade - domina todas as formas de administração.” 120

A atividade administrativa pressupõe, assim, a preexistência de uma regra jurídica que lhe reconheça uma finalidade própria $^{121}$ e exclusivamente para o atingimento dessa finalidade é que está autorizado o agir administrativo.

Estas constatações prestam-se à identificação da atividade administrativa como função.

Carlos Ari SUNDFELD didaticamente, como lhe é próprio, explica:

“Função, para o Direito, é o poder de agir, cujo exercício traduz verdadeiro dever jurídico, e que só se legitima quando dirigido ao atingimento da específica finalidade que gerou sua atribuição ao agente. $O$ legislador, o administrador, o juiz, desempenham função: os podres que receberam da ordem jurídica são de exercício obrigatório e devem necessariamente alcançar o bem jurídico que a norma tem em mira." 122 (grifos nossos)

\footnotetext{
119 Antonio Carlos Cintra do AMARAL analisa a função administrativa sob o enfoque dos interesses tutelados. Assevera o autor, nesse sentido, que "[o] exercício da função administrativa visa ao atendimento do 'interesse coletivo primário', noção desenvolvida pela doutrina jurídica italiana e trazida para a doutrina jurídico-administrativa brasileira, sobretudo por Celso Antonio Bandeira de Mello. $O$ 'interesse coletivo primário' é o interesse da sociedade, que se sobrepõe ao interesse da Administração ('interesse público secundário') e ao interesse privado, também secundário. A função administrativa corresponde ao poderdever, atribuído ao agente administrativo pelo ordenamento jurídico, para realizar o "interesse coletivo primário' (ou, na concepção de Celso Antonio, o dever-poder).” O Princípio da Publicidade no Direito Administrativo, p. 11.

${ }^{120}$ Princípios de Direito Administrativo, p. 39.

${ }^{121}$ Cf. Ruy Cirne LIMA, Princípios de Direito Administrativo p. 40.

${ }^{122}$ Fundamentos de Direito Público, p. 163.
} 
A função administrativa é, assim, como se depreende das lições do autor, um dever jurídico e não uma faculdade da autoridade pública e, um poder legitimado apenas com o cumprimento da finalidade predicada em Lei. ${ }^{123}$

Em boa síntese de Ruy Cirne LIMA assevera que, em tratando da Administração Pública, o dever e a finalidade são predominantes. Já no domínio, a vontade é predominante. ${ }^{124}$

Celso Antonio BANDEIRA DE MELLO possui posicionamento conhecido sobre o tema e inúmeras vezes retransmitido por outros autores. Diz o jurista:

"A idéia de função - e, pois a idéia de função administrativa - reclama do intérprete a intelecção de que o sujeito que a exerce, recebeu da ordem jurídica um dever: $o$ dever de alcançar certa finalidade preestabelecida, de tal sorte que os poderes que lhe assistem foram-lhe deferidos para serem manejados instrumentalmente, isto é, como meios reputados aptos para atender à finalidade que lhes justificou a outorga.(...)A valia do poder, a utilidade e o sentido dele, resumem-se em consistir em instrumento insupimível, sem o qual o agente administrativo não teria como desincumbir-se desse dever posto a seu cargo: dever de concretizar a finalidade legal, isto é, dever de dar satisfação a um interesse de terceiro, a um interesse alheio, no caso, o interesse da coletividade. Logo, o administrador não dispõe de poderes-deveres, como às vezes se diz, mas de deverespoderes, locução que expressa com maior fidelidade que a anterior a verdadeira índole de suas competências."

\footnotetext{
123 Nesse sentido é o posicionamento de Renato ALESSI: "O poder estatal enquanto preordenado às finalidades de interesse coletivo e enquanto objeto de um dever jurídico em relação ao cumprimento delas, constitui uma função estatal.”. Sistema Istituzionale del Diritto Amministrativo Italiano, p. 2.

${ }^{124}$ Princípios de Direito Administrativo, p. 106.
} 
Conforme afirma Celso Antonio BANDEIRA DE MELLO a função administrativa encerra um dever-poder de agir da autoridade pública para a consecução do fim definido em Lei. É, ainda segundo o jurista, é na sua instrumentalidade que se justifica o poder estatal, uma vez que a sua existência tem raízes no dever de a autoridade pública dar provimento à finalidade posta nas normas jurídicas.

Tomás-Ramón FERNANDEZ possui a mesma linha de entendimento do jurista brasileiro. Assenta o autor, nesse sentido, que "todo poder público es um poder funcional, um poder-deber que se otorga a uma autoridad no em consideración al interes próprio de ésta, como es obvio, sino em consideración de los intereses de los ciudadanos y para el beneficio de éstos, ante los que debe justificarse em su ejercicio." 125

Eduardo García de ENTERRÍA é claro a esse respeito:

$$
\begin{aligned}
& \text { "Los poderes administrativosno son abstratos, } \\
& \text { utilizables para cualquier finalidad; son poderes } \\
& \text { funcionales, otorgados por el Ordenamineto en vista de } \\
& \text { um fin específico, com lo que apartarse del mismo } \\
& \text { ciega la fuente de su legitimidad.", }
\end{aligned}
$$

Não é diferente o posicionamento de Carmen Chinchilla MARIN que observa que "en toda actuación administrativa hay, por decirlo de uma manera muy simple, um por quê y um para quê. La Administración actúa porque uma norma la há apoderado en esse sentido para que cumpla uma finalidad de interes público concreta." 127

Afonso Rodrigues QUEIRÓ reforça essa mesma linha ao afirmar que "o fim é, pois, aquêle interesse público cuja realização a lei tem em vista ao conceder a determinada autoridade certo poder de agir". ${ }^{28}$

Caio TÁCITO, ainda, afirma que a finalidade é um elemento de vinculação permanente da conduta administrativa. ${ }^{129}$

\footnotetext{
125 “Viejas y Nuevas Ideas sobre el Poder Discrecional de la Administración y el Control Jurisdicional de su Ejercicio", p. 183.

${ }^{126}$ Curso de Derecho Administrativo, p. 458.

${ }^{127}$ La Desviación de Poder, p. 69.

${ }^{128}$ A Teoria do Desvio de Poder em Direto Administrativo, p. 69-70.

${ }^{129}$ Direito Administrativo, p. 101.
} 
Celso Antonio BANDEIRA DE MELLO, nesse sentido, é taxativo ao afirmar que a atividade administrativa é essencialmente uma atividade infralegal e, nessa toada, que a relação que medeia o administrado e a lei é menos cingida do que a relação que se perfaz entre a Administração Pública e a Lei, isto é, a atividade administrativa é muito mais constrita ao quadro normativo do que a atividade privada. Lembra o autor, ademais, que essa idéia é sintetizada na averbação clássica de que: enquanto o particular pode fazer tudo aquilo que não lhe é proibido, estando em vigor portanto o princípio geral da liberdade, a Administração Pública somente pode fazer o que lhe é permitido por Lei. Logo, a relação existente entre os indivíduos e a Lei é meramente de não contradição, enquanto que a relação existente entre a Administração Pública e a Lei, não só é de não contradição, como também de subsunção. ${ }^{130}$

Gabino FRAGA, nesse sentido, observa que o princípio de que a Administração Pública não pode executar atos individuais que não estejam previstos ou autorizados em dispositivo geral anterior tem, em todos os Estados modernos, um caráter quase absoluto. ${ }^{131}$

Em outra oportunidade, Celso Antonio BANDEIRA DE MELLO esclarece que os deveres-poderes da Administração Pública encerram-se nas suas regras de competên ${ }^{132}{ }^{132}$, cuja destinação única é a satisfação dos interesses dos administrados nas circunstâncias, fins e formas fixados na Lei. ${ }^{133}$

Nesse mesmo enfoque, Marçal JUSTEN FILHO anota que a função pública é um conjunto de competências que se concretizam por meio das atividades administrativas essas, por sua vez, entendidas como a sequência de ações e omissões na persecução dos fins que norteiam e justificam a atribuição de competências às autoridades públicas nos termos da Lei. ${ }^{134}$

\footnotetext{
${ }^{130}$ Discricionariedade e Controle Jurisdicional, p. 12-13.

${ }^{131}$ Derecho Administrativo, p. 115.

${ }^{132}$ É o mesmo autor que esclarece o sentido de competência utilizado nesse contexto. Diz o autor que "não se está a falar de competência em sentido formal, ou seja, concebida pura e simplesmente como um abstrato plexo de poderes, mas em competência no sentido material: no sentido de que, se alguém é investido de uns tanto poderes, não o e para atuá-los em quaisquer circunstâncias ou perante quaisquer fins ou segundo quaisquer formas, mas só o é para mobilizar ditos poderes ante determinadas circunstâncias, em vista de específicos fins e através de certas formas.”. Discricionariedade e Controle Jurisdicional, p. 61.

${ }^{133}$ Legalidade, Motivo e Motivação do Ato Administrativo, p. 60.

${ }^{134}$ Curso de Direito Administrativo, p. 41.
} 
Odete MEDAUAR comenta que a expressão dever-poder expressa, em verdade, a idéia de obrigação de agir da autoridade pública. Para a autora, tal expressão não é necessária se estiver apreendido o sentido que o poder possui no âmbito administrativo, qual seja o de seu exercício preordenado a um fim. ${ }^{135}$ Ressalta, ainda, que mediante a idéia de função conota-se além da canalização da atuação estatal a um fim, a implicação de prerrogativas, deveres, ônus e sujeições da autoridade administrativa.

No mesmo sentido é o posicionamento de Adilson Abreu DALLARI para quem "[t]oda norma que confere uma competência a uma dada autoridade também impõe, a essa mesma autoridade, o dever de exercê-la". Assevera, ainda, o autor que "[o] titular da competência discricionária, diante do caso concreto, não está autorizado a adotar qualquer conduta, mas, sim, tem o dever de desvendar e adotar o único comportamento que as circunstâncias indicarem como o mais adequado.” 136

Carlos Ari SUNDFELD observa, ainda, que quando "a norma jurídica ,tomada isoladamente, não forneça os elementos suficientes para se precisar, de modo objetivo, o fim a ser perseguido, nem por isso este será indiferente. O direito, mesmo nos casos da maior discricionariedade, fornece sempre os elementos para a identificação, por via negativa (isto é, dizendo o que ela não pode ser), da finalidade do ato."137

A ação (ou omissão) ${ }^{138}$ administrativa, portanto, é um dever - e não uma faculdade - e sempre deve estar voltado à consecução da finalidade legal tal como fixado nas regras de competência e, jamais a quaisquer interesses e anseios da autoridade pública, como veremos ao longo deste capítulo.

Apreendida, assim, a noção de função pública imanente no agir administrativo, passamos a abordar a temática decorrente de seus desvios.

\footnotetext{
${ }^{135}$ Direito Administrativo Moderno, p. 106-107.

${ }^{136}$ Controle do Desvio de Poder, p. 35.

${ }^{137}$ Fundamentos de Direito Púbico, p. 165.

${ }^{138}$ Reconhece-se que, por vezes, a omissão da Administração Pública é a conduta que propicia o atingimento da finalidade legal. Cf. Hely Lopes MEIRELLES. Direito Administrativo Brasileiro, p. 106. Nessa esteira, Adilson Abreu DALLARI esclarece, ainda, que: "Não existem prerrogativas puras, não existe a opção entre agir ou não agir. Quando a autoridade competente deixa de atuar, se omite, já cometeu um ilícito administrativo." Controle do Desvio de Poder, p. 35.
} 


\section{3. A Arbitrariedade da Administração Pública.}

Comumente às situações de arbitrariedade da Administração Pública são associadas, quase que automaticamente, ao campo de sua discricionariedade; não obstante, também é possível se verificar, ainda que com muito menor frequiência, o arbítrio das autoridades públicas em casos em que se evidencia um maior grau de vinculação e um grau apenas residual de discricionariedade. É que nesses casos não remanesce, ou remanesce em pequeníssima escala, margem de atuação própria à autoridade pública, haja vista que a sua ação maiormente já está fixada na Lei. ${ }^{139}$

Essa problemática é bem captada por Adilson Abreu DALLARI:

"Toda autoridade, ao atuar, ao decidir, exerce uma competência que the foi atribuída por lei. Quando a autoridade age no exercício de competência vinculada, os desvios de conduta são facilmente identificáveis, pois, em tais casos, o ato a ser praticado é previamente estipulado pela lei, não comportando alternativas. $O$ problema surge quando a lei confere à autoridade uma competência discricionária, que, em tese, comporta uma pluralidade de opções, decisões ou comportamentos, seja por expressamente facultar diferentes soluções, seja por se utilizar de expressões vagas, possibilitando diferentes interpretações.

Ocorre que discricionariedade não é arbitrariedade ${ }^{141}$. A capacidade confiada por Lei, ocasionalmente, às autoridades públicas para discernir, optar e implementar a

\footnotetext{
${ }^{139}$ Ver a esse respeito Carmem CHINCHILLA MARIN. La Desviacion de Poder, p. 57 e ss.

${ }^{140}$ Controle do Desvio de Poder, p. 34.

${ }^{141}$ Cf. Tomás-Ramón FERNÁNDEZ. Arbitrariedad y Discrecionalidad, p. 106. Recentemente, em 2006, o mesmo jurista apresenta interessante construção doutrinária. Afirma o autor que discricionariedade é arbítrio no sentido de que é uma faculdade de adotar uma resolução com peferência a outra ou outras possíveis que a Lei outorga a um autoridade dentro de margens próprias. Esse seria pois o arbítrio legítimo, autorizado por lei, o qual não se confunde com a arbitrariedade proibida, ao contrário, o arbítrio legítimo e a arbitrariedade proibida, para o autor, são, ainda, conceitos antagônicos, separados pela existência de uma justificação suficiente da decisão administrativa, isto é, da razão ou razões que suportam a escolha realizada pela autoridade pública, sem as quais a opção discricionária revela-se expressão de puro capricho e vontade desnuda. "Viejas y Nuevas Ideas sobre el Poder Discrecional de la Administración y el Control Jurisdicional de su Ejercicio”, p. 182-183.
} 
melhor solução ${ }^{142}$ a cada caso concreto, não lhe autoriza a agir de modo arbitrário. Muito pelo contrário, somente serão legítimas as escolhas públicas que estejam de acordo com o ordenamento jurídico pátrio - isto é, nos lindes da juridicidade, como vimos no Capítulo I - e que resultem na decisão ótima ao caso concreto, tema que será abordado no Capítulo V. ${ }^{143}$

A concepção de que a discricionariedade conferiria à Administração Pública liberdade irrestrita e insindicável - errônea e ultrapassada, mas que durante muito tempo prosperou sem oposição - incutiu nas autoridades públicas, ao longo do tempo, a idéia de que não se encontrariam submetidas à Lei nesse agir e de que seriam imunes a qualquer tipo de controle; de modo que, sob a escusa de se atuar discricionariamente, perpetravamse arbitrariedades. Assim é até hoje, talvez em menor medida, em razão da evolução da referida concepção aliada às diversas iniciativas para controle da Administração Pública.

Fato é que extenso caminho, ao longo dos séculos, vem sendo percorrido pelos indivíduos para extirpar o arbítrio e o subjetivismo no exercício do poder estatal. Do Estado Absolutista passou-se ao Estado de Direito, em que se subordinou, como vimos, o agir administrativo à Lei e, a partir das primeiras décadas do século XIX, constituiu-se e consolidou-se alguns ramos do Direito Público, em especial o Direito Constitucional e o Direito Administrativo, para direcionar o exercício do poder estatal, eliminando-se o arbítrio. ${ }^{144}$ Essa tarefa longe está de concluída e revela-se um desafio diário na relação entre os administrados e a Administração Pública.

Cumpre esclarecer, antes de prosseguirmos, o teor do termo arbitrariedade e, por conseguinte, do termo arbitrário a que nos referimos e aludiremos ao longo de toda dissertação.

Os termos arbitrariedade e arbítrio são empregados nesse trabalho em sua acepção moderna de contrariedade ao ordenamento jurídico e à razão ou, ainda, de

\footnotetext{
142 "Elegir la mejor solución es siempre obligado para todo aquel que ejercita uma función”.Tomás R. FERNÁNDEZ. De la Arbitrariedad de la Administración, p. 91.

${ }^{143}$ Adilson Abreu DALLARI afirma no mesmo sentido que: "Não se pode confundir arbitrariedade $e$ discricionariedade: a primeira corresponde a um comportamento flagrantemente ilícito; a segunda corresponde ao exercício de uma opção entre as várias possibilidades proporcionadas pela regra da competência. O foco do problema está no mau exercício da competência discricionária.” Controle do Desvio de Poder, p. 34.

${ }^{144}$ Cf. Odete MEDAUAR, p. 340.
} 
subjetivismo desvinculado da realidade, como bem delimitado por Tomás-Ramón FERNÁNDEZ. ${ }^{145}$

As discussões acerca da arbitrariedade da Administração Pública e, por óbvio, como contê-la, são bem desenvolvidas na Espanha e foram impulsionadas em razão do art. 9.6, da Constituição espanhola, que expressamente predica principiológicamente a interdição à arbitrariedade a todas as formas de manifestação do Estado espanhol. ${ }^{146}$

Eduardo García de ENTERRÍA quem introduziu e desenvolveu inauguralmente, em 1959, no Direito espanhol, a idéia de um princípio de interdição à arbitrariedade da Administração Pública oponível como um limite de sua atuação ${ }^{147}$, posteriormente, adotado pela Constituição espanhola de $1978 .{ }^{148} \mathrm{O}$ jurista declaradamente baseou-se na obra Die Gleichheitvor Dem Gesetz, do alemão LEIBHOLZ, adotando o conceito desse autor, adaptando-o ao cenário espanhol e ampliando-o. ${ }^{149}$

Eduardo García de ENTERRÍA, compartilhando do entendimento de LEIBHOLZ, constata que o arbitrário é o contrário do razoável e o oposto à justiça. Os autores estabelecem, ainda, uma correspondência entre arbitrariedade e abuso de discricionariedade nos Estados Modernos; de modo que, a construção do princípio da

\footnotetext{
${ }^{145} \mathrm{O}$ autor investiga com cuidado as acepções de arbitrariedade e arbítrio na história; caminha também pela literatura de diversos países e busca a acepções desses termos não só em castelhano, mas também em francês, italiano, alemão e inglês. Modernamente, observa Tómas-Ramón FERNÁNDEZ que as acepções convergem em um sentido pejorativo de despotismo, tirania, absolutismos, caprichoso e infundado. Vale a pena conhecer sua abordagem ao tema em De la Arbitrariedad de la Administración, p. 158 e ss, especialmente nota de rodapé 57.

${ }^{146}$ Cf. Tómas-Ramón FERNÁNDEZ. De la Arbitrariedad de la Administración, p. 158

${ }^{147}$ Não sei ser questionado por outros doutrinadores como, por exemplo, Francisco Rubio LLORENTE em Juez y Ley desde el punto de vista del Principio de Igualdade, artigo da obra El Poder Judicial em el Bicentenario de la Revolucion Francesa, p. 91 e ss. Para esse autor a inserção do princípio da interdição à arbitrariedade representavou uma recepção pouco meditada de terminologias estrangeiras no ordenamento jurídico espanhol, sendo, ainda, desnecessária pois equivaleria ao princípio da igualdade.

${ }^{148}$ Tomás-Ramón FERNÁNDEZ anota que é um mérito importante da jurisprudência contenciosaadministrativa ter desenvolvido uma nova teoria do poder discricionário e de seu controle judicial a partir do novo texto da Constituição espanhola.Para o jurista espanhol o leading case refere-se ao recurso contenciosoadministrativo promovido a propósito da delimitação do âmbito territorial da denominação de origem "jerezxerez - sherry" resolvido na sentença de 13 de julho de 1984 pelo Supremo Tribunal espanhol. Nesta sentença referido Tribunal assentou que "nunca es permitido confundir lo discrecional com lo arbitrário, pues aquello (lo discrecional) se halla o debe hallarse cubierto por motivaciones suficientes, discutibles o no, pero considerables em todo caso y no meramente de uma ciudad que les haga inatacables, mientras que lo segundo (lo arbitrario) no tiene motivación respetable, sino - pura y simplesmente - la conocida sit pro ratione voluntas o la que ofrece lo es tal que, escudriñando su entraña, denota, a poco esfuerzo de contrastación, su carácter indefinible y su inautenticidad." “Viejas y Nuevas Ideas sobre el Poder Discrecional de la Administración y el Control Jurisdicional de su Ejercicio”, p. 177.

${ }^{149}$ Es Inconveniente o Inutil la Proclamación de la Interdicción de la Arbitrariedad como Principio Constitucional? Uma nota. Revista de Administración Pública, n. ${ }^{\circ}$ 14, 1991, p. 2.
} 
interdição à arbitrariedade busca afirmar a vinculação da ação administrativa ao ordenamento jurídico. ${ }^{150}$

Tomás-Ramón FERNÁNDEZ explica, também, o teor do art. 9.6 da Constituição espanhola e assim, complementamos, o sentido das acepções dos termos arbitrariedade e arbítrio utilizado ao longo dessa dissertação. Diz o autor que o princípio da interdição do arbítrio $^{151}$ da Constituição espanhola apresenta duplo significado: um genérico, no sentido de oposto ou negativo à Justiça e ao Direito e, outro mais concreto, atinente ao que carece de fundamentação objetiva, como incongruente ou contraditório com a realidade, desprendido ou alheio à razão. ${ }^{152}$

Denota-se do sentido conferido aos termos arbitrariedade e arbítrio, tal como defende Eduardo García de ENTERRÍA, que a proibição à Administração Pública arbitrária visa combater a falta de um fundamento objetivo, isto é, um agir administrativo cujo móvel seja fruto de vontade pessoal e capricho da autoridade pública. Conforme o autor espanhol, os valores do Estado de Direito devem guiar, com exclusividade, as decisões administrativas. ${ }^{153}$ Daí que Germana de OLIVEIRA depreende que na doutrina espanhola, o conceito de arbitrariedade abrange também a irrazoabilidade. ${ }^{154}$

Manuel ATIENZA anota que "o Estado de Direito significa a submissão do Estado, do poder, à razão, e não da razão ao poder”. E explica:

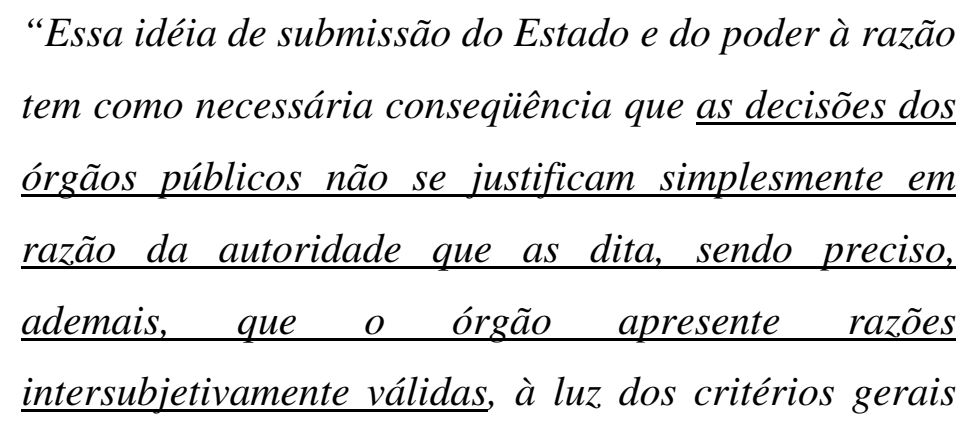

${ }^{150}$ Es Inconveniente o Inutil la Proclamación de la Interdicción de la Arbitrariedad como Principio Constitucional? Uma nota, p. 4.

${ }^{151}$ Segundo o autor esse princípio expressa-se na imprescindível motivação e fundamentação objetiva das decisões administrativas discricionárias. Arbitrariedade y Discrecionariedad, p. 106 e ss.

${ }^{152}$ De la Arbitrariedad de la Administración, p. 163.

${ }^{153}$ Legislación Delegada, Potestad Reglamentaria y Control Judicial, p. 189 e ss.

${ }^{154}$ Controle Jurisdicional da Administração Pública. São Paulo: Dialética, 1999, p. 88. 


\section{da racionalidade prática e dos critérios gerais positivados na ordem jurídica." 155 (grifos nossos)}

Eduardo García de ENTERRÍA esforça-se, ainda, com base no referido princípio da Constituição espanhola, em identificar situações que evidenciariam arbitrariedade da Administração Pública e, nessa medida, deveriam ser anuladas pelos Tribunais, quais sejam: (i) partir de uma apreciação falsa dos fatos; (ii) romper com o princípio da igualdade; (iii) transgredir os princípios institucionais; (iv) faltar com a proporcionalidade; (v) manipular os meios elementares de vida como instrumento de coerção; (vi) desvio de poder; (vii) violação dos direitos fundamentais; (viii) retroatividade; (ix) iniquidade manifesta; (x) justiça natural (no sentido inglês); (xi) irrazoabilidade; (xii) faltar com a boa fé exigível da Administração Pública; e (xiii) violar a reserva de Lei.

Perceba-se que todas as situações apresentadas pelo autor, direta ou indiretamente, representam deformações no processo de formação da decisão administrativa por ausência de objetividade e racionalidade da autoridade administrativa. $\mathrm{O}$ rol de arbitrariedades catalogado pelo autor é, com efeito, universal a todos os Estados Modernos, mas não se pode dizer que taxativo, haja vista que a criatividade daqueles que intentam utilizar arbitrariamente das competências que lhe são atribuídas por Lei é inesgotável.

Embora não haja na Constituição Federal brasileira um dispositivo similar àquele da Constituição espanhola, a moderna dogmática administrativa é tranqüila em afirmar que, mesmo nos espaços de relativa liberdade de apreciação conferidos pelo Legislador, a Administração Pública, ao exercê-la, não pode fazê-lo arbitrária, incoerente ou inequanicamente. ${ }^{156}$

Com efeito, pode-se afirmar que a vedação à Administração Pública arbitrária permeia toda a Constituição Federal brasileira e assenta-se, como vimos no item anterior, na concepção basilar de Estado de Direito, ao qual é inerente a subsunção das autoridades públicas à Lei e o manejo dos deveres-poderes que lhes são conferidos exclusivamente para atender às finalidades previstas no ordenamento jurídico.

\footnotetext{
${ }^{155}$ Sobre lo Razonable en el Derecho, p. 15.

156 Cf. Alexandre Santos de Aragão. Teoria das Autolimitações Administrativas: atos Próprios, Confiança Legítima e Contradição entre Órgãos Administrativos, p. 2
} 
Identificar, entretanto, hodiernamente, a arbitrariedade travestida de discricionariedade não é uma tarefa fácil. Mais e mais, os casos de evidente uso arbitrário da discricionariedade dão lugar a situações de dissimulação da conduta arbitrária das autoridades públicas.

Por isso, desenvolveram-se diversas teorias destinadas à identificação e controle do uso arbitrário da discricionariedade pelas autoridades públicas. Importa-nos especialmente a teoria relativa ao desvio de poder, que abarca uma ampla gama de situações de arbitrariedade associadas à discricionariedade, e a teoria da captura, focada na regulação setorial e, pois, de capital importância nesta dissertação. Trataremos de cada uma delas nos itens seguintes.

\section{4. Desvio de Poder.}

Hely Lopes MEIRELLES bem introduz o tema a partir das noções de uso e abuso do poder estatal. $\mathrm{O}$ autor inicia sua abordagem remontando à idéia nuclear de que em um Estado de Direito, como o nosso, a Administração Pública, em todas as suas manifestações, inclusive nas discricionárias, deve obediência à Lei. ${ }^{157}$

Contemporaneamente, como vimos no Capítulo I, poderíamos ampliar essa idéia e afirmar que a Administração Pública vincula-se à juridicidade; e, em decorrência de tal sujeição, as ações administrativas, com qualquer grau de vinculação ou de discricionariedade, devem estar adstritas aos moldes predicados no ordenamento jurídico pátrio.

É que a prerrogativa de ação estatal justifica-se apenas e tão-somente para a consecução dos fins legais e pelos meios também predicados em Lei. Em outras palavras, o uso do poder estatal é prerrogativa da autoridade pública, mas tal poder deve ser utilizado normalmente, sem abusos. ${ }^{158}$ Utilizar normalmente esse poder, como anota Hely Lopes MEIRELLES, é empregá-lo segundo as normas legais, a moral da instituição, a finalidade do ato e as exigências de interesse público. Abusar do poder, segundo o autor, é empregálo fora da Lei, sem utilidade pública. ${ }^{159}$

\footnotetext{
${ }^{157}$ Direito Administrativo brasileiro, p. 101-102.

${ }^{158}$ Cf. Hely Lopes MEIRELLES. Direito Administrativo Brasileiro, p. 102.

${ }^{159}$ Direito Administrativo Brasileiro, p. 102.
} 
Hely Lopes MEIRELLES é contundente ao afirmar que "[o] uso do poder é lícito; o abuso sempre ilícito. Daí porque todo ato abusivo é nulo, por excesso ou desvio de poder.” 160

O autor explica, nesse sentido, que o abuso de poder ocorre quando a autoridade, embora competente para praticar o ato, ultrapassa os limites de suas atribuições ou se desvia das finalidades administrativas. ${ }^{161}$

Estes dois aspectos do abuso de poder revelam, pois, as figuras do excesso de poder e do desvio de poder. Ambas refletem situações de arbitrariedade da autoridade pública e tornam o ato, assim emanado, nulo. Iremos nos focar, adiante, no desvio de poder, uma vez que é a figura comumente associada às arbitrariedades perpetradas pelas autoridades públicas no manejo da discricionariedade.

Com raízes fixadas na jurisprudência do Conselho de Estado Francês, a teoria do desvio de poder, como instrumento de controles dessa espécie de arbitrariedade, restou incorporada a inúmeros ordenamentos jurídicos do mundo ocidental como mecanismo para a contenção do arbítrio estatal. ${ }^{162}$

No Brasil não foi diferente, embora o tratamento legislativo do tema tenha sido incipiente $^{163}$, a doutrina administrativista pátria, desde muito cedo, reconheceu a figura do desvio de poder e conferiu-lhe tratamento próprio no ordenamento jurídico brasileiro. ${ }^{164}$

Celso Antonio BANDEIRA DE MELLO dispensou oportunamente longo trato ao tema. Assevera o jurista que desvio de poder é a utilização de uma competência em desacordo com a finalidade que lhe preside a instituição. É o próprio autor que, assim, desenvolve a noção apresentada:

\footnotetext{
${ }^{160}$ Direito Administrativo Brasileiro, p. 102.

${ }^{161}$ Direito Administrativo Brasileiro, p. 102. No mesmo sentido são as lições de Diógenes GASPARINI. O Desvio de Poder ou de Finalidade em Matéria Administrativa.

${ }_{162}$ Para conhecer a figura do desvio de poder no direito comparado ver O Desvio de Poder na Administração Pública. José CRETELLA JUNIOR.

${ }^{163}$ Em 1984, a Lei n. ${ }^{\circ} 221$ fez referência breve ao excesso de poder como causa de invalidade de "medida administrativa tomada em virtude de uma faculdade ou poder discricionário". Em1951, a Lei n. ${ }^{\circ} 1.522$ fez alusão ao desvio de poder, não para eivar de nulidade o ato administrativo, mas para sujeitar o agente que praticou o ato à destituição do cargo. Em 1965, a Lei n. ${ }^{\circ}$ 4.717, que disciplina a ação popular, enfim, dentre as hipóteses de nulidade dos atos administrativos, faz expressa menção ao desvio de finalidade.

${ }^{164}$ Miguel SEABRA FAGUNDES foi um dos pioneiros no trato da matéria com o seu O Controle dos Atos Administrativos pelo Poder Judiciário.
} 
“Consiste, pois, [o desvio de poder] no manejo de um plexo de poderes (competência) procedido de molde a atingir um resultado diverso daquele em vista do qual está outorgada a competência. $O$ agente se evade do fim legal, extravia-seda finalidade cabível em face da lei. Em suma: falseia, deliberadamente ou não, com intuitos subalternos ou não, aquele seu dever de operar o estrito cumprimento do que a lei configurou como objetivo prezável e atingível por dada via jurídica” 165

Tratando-se, como anota ainda o autor, de um comportamento que se desgarra do fim legal, é, em suma, uma transgressão da lei. ${ }^{166}$

André de LAUBADÈRE apresenta noção bastante similar do desvio de poder:

$$
\begin{aligned}
& \text { "Há desvio de poder quando uma autoridade } \\
& \text { administrativa cumpre um ato de sua competência mas } \\
& \text { em vista do fim diverso daquele para o qual o ato } \\
& \text { poderia legalmente ser cumprido." } 167
\end{aligned}
$$

As lições de Hely Lopes MEIRELLES são no mesmo sentido, mas um pouco mais abrangente, pois, engloba as duas principais facetas do desvio de poder:

"O desvio de finalidade ou de poder verifica-se quando a autoridade, embora atuando nos limites de sua competência, pratica o ato por motivos ou com fins diversos dos objetivados pela lei ou exigidos pelo interesse público. O desvio de finalidade ou de poder é, assim, a violação ideológica da lei, ou, por outras palavras, a violação moral da lei, colimando o administrador público fins não queridos pelo legislador, ou utilizando motivos e meios imorais para

\footnotetext{
${ }^{165}$ Discricionariedade e Controle Jurisdicional, p. 57.

${ }^{166}$ Lembre-se que só há desvio de poder quando a autoridade possui, em tese, competência para agir com relação ao objeto do ato administrativo, pois, se mesmo abstratamente não lhe é atribuída competência por lei, o vício seria de incompetência formal e não de desvio de poder.

${ }^{167}$ Traité Élémentaire de Droit Administratif, LGDF, 5a edição, vol. I, 1970, p. 502, n. ${ }^{\circ} 894$.
} 


$$
\begin{aligned}
& \text { a prática de um ato administrativo aparentemente } \\
& \text { legal." } 168
\end{aligned}
$$

Celso Antonio BANDEIRA DE MELLO identifica, nessa toada, duas modalidades de desvio de poder. Uma em que a autoridade pública, servindo-se de uma competência que possui em tese, busca uma finalidade alheia a qualquer interesse público. E outra em que manejando uma competência, que possui em abstrato, busca atender uma finalidade pública que não é aquela própria e específica da competência utilizada. ${ }^{169}$

O autor explica que na primeira situação a autoridade pública atua para alcançar um fim pessoal que tanto pode ser perseguição a alguém como de favoritismos ou mesmo para atender um interesse individual do próprio agente estatal, trata-se, assim, de um vício de intenção da autoridade pública; e que na segunda situação pode ser que a autoridade pública não tenha agido de má-fé, mas julgado equivocadamente competência que possui, caracterizando-se, nessa medida, verdadeiro vício de procedimento. ${ }^{170}$

Em ambos os casos terá ocorrido desvio de poder posto que as competências das autoridades públicas tem endereço certo - não são um cheque em branco $^{171}$ - e, pois, não podem ser manejadas para fins distintos daqueles fixados em Lei.

É, nesta medida, que a doutrina administrativista pátria identifica o desvio de poder como vício relativo à finalidade dos atos administrativos ${ }^{172}$ daí porque também é conhecido como desvio de finalidade.

Caio TÁCITO observa a esse respeito que:

"O uso da competência para a prática de ato que não visa a alcançar a finalidade legal, mas sob a aparência de fazê-lo, pretende realmente servir a outro fim, caracteriza uma espécie peculiar de vício do ato administrativo. Como, nessa hipótese, a manifestação

\footnotetext{
${ }^{168}$ Direito Administrativo Público Brasileiro, p. 104-105.

${ }^{169}$ Discricionariedade e Controle Judicial, p. 58-59.

${ }^{170}$ Discricionariedade e Controle Judicial, p. 58-59.

${ }^{171}$ As expressões são de Caio TÁCITO. Direito Administrativo. São Paulo: Saraiva, 1975, p. 5.

172 Diogo de Figueiredo MOREIRA NETO anota, entretanto, que os vícios de finalidade são conhecidos na doutrina italiana como "vícios de mérito". O autor declara que não concorde com a nomenclatura alienígena, uma vez que para ele o vício não reside diretamente na incorreção ou desacerto da opção discricionária, mas, indiretamente, na insatisfação do interesse público específico, implícito no elemento vinculado finalidade. Legitimidade e Discricionariedade, p. 35.
} 
de vontade do agente segue direção diversa daquela que o legislador concebeu e, portanto, se desvia do alvo legal, a jurisprudência francesa batizou-a com o nome de détournement de pouvoir ou, em vernáculo, desvio de poder ou, ainda, desvio de finalidade." 173

Miguel SEABRA FAGUNDES já anotava que os atos administrativos que se desviam de suas finalidades legais devem ser anulados.

"A atividade administrativa sendo condicionada pela lei á obtenção de determinados resultados, não pode a Administração Pública deles se desviar, demandando resultados diversos dos visados pelo legislador. Os atos administrativos devem procurar atingir as consequências que a lei teve em vista quando autorizou a sua prática, sob pena de nulidade." 174

Em seqüência, o jurista afirma, ainda, que o que ocorre nessas situações é uma burla da intenção legal, haja vista que a autoridade pública atua contrariando o espírito da lei. E mesmo que a diferente finalidade alcançada tenha sido moralmente lícita e justa, o ato será inválido. ${ }^{175}$

É corrente, ainda, na doutrina administrativista, que o desvio de poder envolve um vício de legalidade ${ }^{176}$ que recai sobre a finalidade do ato administrativo. ${ }^{177}$

Celso Antonio BANDEIRA DE MELLO chama a atenção para o fato de que o desvio de poder, desvinculado de qualquer finalidade pública, tem lugar especialmente quando a autoridade pública encontra-se no exercício da discricionariedade. ${ }^{178}$ Afirma o autor que a doutrina administrativista caracteriza genericamente o desvio de poder como

\footnotetext{
173 Temas de Direito Público, $1^{\circ}$ Vol., 1997, p. 165.

${ }^{174}$ O Controle dos Atos Administrativos pelo Poder Judiciário, p. 89.

${ }^{175}$ O Controle dos Atos Administrativos pelo Poder Judiciário, p. 89.

${ }^{176}$ Cf. Jose CRETELLA JR. O Desvio de Poder na Administração Pública, p. 183-190.

177 Quanto à natureza do vício, se subjetivo ou objetivo, permanece na doutrina administrativista alguma divergência, que para o escopo desse trabalho não importa aprofundar.

${ }^{178}$ Caio TÁCITO afirma que: “O desvio de poder é, por definição, um limite à ação discricionária, um freio ao transbordamento da competência legal além de suas fronteiras, de modo a impedir que a prática do ato administrativo, calcada no poder de agir do agente, possa dirigir-se à consecução de um fim de interesse privado, ou mesmo de outro fim público estranho á previsão legal.” Desvio de Poder no Controle dos Atos Administrativos, Legislativos e Jurisdicionais. p. 32.
} 
ilegitimidade específica dos atos discricionários. Nestes atos, explica Celso Antonio BANDEIRA DE MELLO que a autoridade pública atua disfarçadamente, exibindo como capa do ato algum motivo liso perante o direito. ${ }^{179}$

Como de costume, nas graves palavras do autor:

“Trata-se, pois, de um vício particularmente
censurável, já que se traduz em comportamento
insidioso. A autoridade atua embuçada em pretenso
interesse público, ocultando dessarte seu malicioso
desígnio. Sob a mascarada legalidade, procura, à
esconsa, alcançar finalidade estranha à competência
que possui. Em outras palavras: atua à falsa-fé.
Enquanto de público o ato se apresente escorreito, na
verdade possui uma outra face que se forceja ${ }^{180}$ por
ocultar, já que é constituída de má-morte e orientada
por escopos subalternos." 181

Não é por outra razão que, freqüentemente, o desvio de poder resultante de exercício arbitrário da discricionariedade é associado à falta moral da autoridade pública. $^{182}$

Hely Lops MEIRELLES assevera a esse respeito que o desvio de poder é a “violação ideológica da lei ou, por outras palavras, a violação moral da lei, colimando o administrador público fins não queridos pelo legislador, ou utilizando motivos e meios imorais para a prática de um ato administrativo aparentemente legal.” 183

Manoel de Oliveira Franco SOBRINHO destaca, nesse sentido, que a ausência de moralidade é pressuposto do ato administrativo viciado por desvio de poder. Afirma o

\footnotetext{
${ }^{179}$ Discricionariedade e Controle Jurisdicional, p. 63.

${ }^{180}$ Discricionariedade e Controle Jurisdicional, p. 63.

${ }^{181}$ Discricionariedade e Controle Jurisdicional, p. 63.

182 Cf. Maria Sylvia Zanella DI PIETRO. Discricionariedade Administrativa na Constituição de 1988, p. 150 e ss. Acerca da associação entre moralidade administrativa e desvio de poder ver também os seguintes artigos: Moralidade Administrativa de Antônio José BRANDÃO. Revista de Direito Administrativo RDA. Rio de Janeiro: Renovar, vol. 25, 1951; e A Moralidade Administrativa - História de um Conceito de José Guilherme GIACOMUZZI.

${ }^{183}$ Direito Administrativo Brasileiro, p. 105.
} 
autor que nessas situações a ilegalidade revela-se como sinônimo de não moralidade em face da conduta da autoridade pública. ${ }^{184}$

A intenção viciada da autoridade pública importa, na prática, em real dificuldade para a sua apuração e confrontação. ${ }^{185}$ Isso porque o desvio de poder nunca é explícito e somente pode ser identificado por meio de um feixe de indícios convergentes, dado que é um ilícito caracterizado pelo disfarce, pelo embuste, pela aparência de legalidade, para encobrir o propósito de atingir um fim contrário ao direito. ${ }^{186}$

Essa dificuldade leva os doutrinadores a reconhecer que é necessário que se encontre na formação da decisão administrativa discricionária suspeita um feixe de indícios convergentes $^{187}$ ou provas indiciárias e elementos circunstâncias ${ }^{188}$ que possibilitem constatar a ocorrência do desvio de poder da autoridade pública.

José CRETELLA JUNIOR dedicou-se especialmente ao tema da prova no desvio de poder e, com propriedade asseverou oportunamente que "a prova no desvio de poder desafia também a argúcia do intérprete que pretende surpreender o animus do administrador, mascarando-se essa conduta de maneira sutil e escapando, não raro á apreensão objetiva." O autor apresenta, ainda, as condutas ou deslizes, provas que seriam sintomas de atos administrativos praticados com desvio de poder, quais sejam: “a) contradição do ato com conduta posterior do administrador; b) contradição do ato com conduta anterior; c) motivação contraditória; d) motivação insuficiente; e) alteração dos fatos; f) ilogicidade manifesta; g) disparidade de tratamento; h) derrogação de norma interna; i) precipitação com que o ato foi editado; j) inexistência, de fato, dos motivos apresentados pelo administrador para justificar a decisão tomada; l) desigualdade de tratamento dispensada aos interessados; $m$ ) caráter sistemático de certas proibições; $n$ ) caráter geral atribuído a medida que deveria permanecer particular; o) circunstâncias locais que antecederam a edição do ato; p) feixe convergente de indícios. "189

\footnotetext{
${ }^{184}$ O Princípio Constitucional da Moralidade Administrativa, p. 118.

${ }^{185}$ Carmen Chinchilla MARIN explica que: "Precisamente porque la desviación es consciente y deliberada resulta tan difícil suprueba, porque hay que indagar en las intenciones más escondidas de la Administración para demostrar al juez que la misma quiso atender com su acto um fin diferente a aquel que Le asigna la norma." La Desviacion de Poder, p. 84.

${ }^{186}$ Cf. Adilson Abreu DALLARI. Controle do Desvio de Poder, p. 39.

${ }^{187}$ Jean Rivero.Droit Administratif. Paris: Dalloz, $2^{a}$ edição, 1962, p. 224.

${ }^{188}$ Cf. Agustin Gordillo. Tratado de Derecho Administrativo, p. 33.
}

${ }^{189}$ A Prova no Desvio de Poder, p. 198. 
Importante, ademais, contrastar a dificuldade da prova do desvio de poder com a presunção de legitimidade dos atos administrativos. Sobre o tema, Adilson Abreu DALLARI bem demarca que, muitas vezes, se dá o afastamento da verificação de possível desvio de poder por aplicação exacerbada e indevida do princípio da presunção de veracidade e legitimidade dos atos administrativos. ${ }^{190}$

O autor anota que, de fato, esse princípio é necessário para o bom andamento dos assuntos administrativos, mas deve significar, tão-somente, que as ações administrativas são válidas até que sejam questionadas. È dizer, assim, que uma vez que sejam postas em dúvida a veracidade e/ou a legitimidade do ato administrativo, a Administração Pública deve demonstrar a regularidade da sua conduta. Conclui o autor, nesse sentido, que tal presunção é de natureza precária e subsiste apenas enquanto não questionada pelos administrados. ${ }^{191}$

Um último ponto, ainda, merece ser tocado no que tange ao desvio de poder; trata-se da possibilidade de que este seja perpetrado não por meio de uma ação, mas de uma omissão da autoridade pública. ${ }^{192}$

Essa possibilidade é bem destacada por Juarez FREITAS que classifica os vícios da discricionariedade em dois tipos: (1) arbitrariedade por ação; e (2) arbitrariedade por omissão. Conforme o autor, o primeiro tratar-se-ia exatamente das hipóteses que apresentamos acima, ou seja, de ultrapassagem dos limites impostos à competência discricionária da autoridade pública. Já o segundo referir-se-ia à hipótese em que a autoridade pública deixa de exercer a escolha administrativa ou a exerce com inoperância. A omissão estatal, assim, seria traduzida no descumprimento de diligências impositivas da Lei. $^{193}$

Celso Antonio BANDEIRA DE MELLO assevera a esse respeito que o agente estatal pode decidir não agir, quando deveria expedir um ato para o devido cumprimento da finalidade legal, animado por intuitos de perseguição, favoritismos ou, de todo modo, objetivando finalidade alheia à da regra de competência que o habilitava. ${ }^{194}$

\footnotetext{
${ }^{190}$ Controle do Desvio de Poder, p. 42.

${ }^{191}$ Controle do Desvio de Poder, 46, 2003, p. 42.

${ }^{192}$ Ver a esse respeito Hely Lopes MEIRELLES. Direito Administrativo Brasileiro, p. 106-107.

${ }^{193}$ Discricionariedade Administrativa e o Direito à Boa Administração Pública, p. 27-28.

${ }^{194}$ Discricionariedade e Controle Jurisdicional, p. 75.
} 
Apresentadas, assim, as principais noções que envolvem o tema do desvio de poder, conquanto espécie de arbitrariedade estatal, diretamente relacionada ao transbordamento dos limites da discricionariedade, cumpre, então, tratar, de maneira bastante breve, do desvio de poder no âmbito das Agências Reguladoras, isto é, da captura do regulador.

\section{5. A Captura do Regulador.}

O desvirtuamento das funções regulatórias ou o transbordamento das competências do regulador, como anota Sérgio GUERRA, importam em vício de mérito ou de finalidade do ato regulatório. Conforme esclarece o autor, esses vícios afastam o regulador da realização do interesse da coletividade e o aproximam de fins políticoeleitoreiros ou, tão-somente, revelam posicionamentos tendenciosos a grupos de interesses ou caprichosos do regulador. ${ }^{195}$ Essa modalidade de vício de poder configuraria, pois, no âmbito regulatório, a captura do regulador ${ }^{196}$, um dos maiores riscos das Agências Reguladoras. ${ }^{197}$

Atento a esse fenômeno George Stigler, em 1971, em seu The Theory of Economic Regulation desenvolveu a reconhecida Teoria da Captura (Capture Theories) das Agências Reguladoras que tornou um marco sobre o tema. Nesse trabalho, a linha de pensamento do autor consiste na contaminação das Agências Reguladoras pelos diversos grupos de interesses, com vistas à obtenção de benefícios. ${ }^{198}$

Alexandre Santos de ARAGÃO assevera que uma vez que as Agências Reguladoras foram constituídas para propiciar uma regulação mais eficiente de atividades de especial interesse e sensibilidade da sociedade, "não faria sentido que elas fossem

\footnotetext{
${ }^{195}$ Em monografia sobre o tema Andreia Cristina BAGATIN afirma: "Entender que há desvio de poder quando o agente administrativo deixa de buscar o interesse público para tutelar interesse de outra índole (inclusive eventuais interesses privados) não é muito distante da afirmação de que o problema da captura ocorre quando o regulador tutela interesses específicos (privados ou políticos) em detrimento do interesse geral.” O Problema da Captura das Agências Reguladoras Independentes, p. 165.

${ }^{196}$ Introdução ao Direito das Agências Reguladoras, p. 56-57.

${ }^{197}$ Cf. Alexandre Santos de ARAGÃO. Agências Reguladoras e a Evolução do Direito Administrativo Econômico, p. 365.

${ }^{198}$ A Teoria da Regulação Econômica, p. 23-49.
} 
neutralizadas em relação ao poder político e deixadas livres à influência econômica dos poderosos interesses regulados." 199

Fábio NUSDEO observa que "os grupos de interesse tendem, desde logo, a capturar as agências reguladoras. Estas nem sempre se destinam a proteger o público, mas podem vir a significar uma defesa e proteção para os empresários do setor (...)” e até mesmo uma "possível atenuação dos vínculos de fiscalização e controle originalmente previstos". 200

Com efeito, a estreita relação entre o regulador e os regulados pode impulsionar afinidades e antipatias e possibilitar que o regulador seja capturado por grupos de interesses privados privilegiando-lhes quando em confronto com os interesses da coletividade ou, no mais das vezes, conferindo-lhes prevalência sobre outros interesses particularísticos arbitrariamente.

A autora conclui, nesse sentido, que embora a Teoria do Desvio de Poder possa auxiliar na contenção da captura, é inafastável a necessidade de que novos mecanismos mais condizentes com a realidade do Estado Regulador sejam cunhados. ${ }^{201}$ É, pois, considerando essa ordem de fatores, que se dedica o presente trabalho à identificação de parâmetros concretos e objetivos para o acompanhamento e controle das decisões regulatórias discricionárias da ANATEL, como trataremos no Capítulo V.

\section{6. Conclusões.}

Cumpre, no Estado de Direito, que os regulados se encontrem, de antemão, assegurados contra um agir administrativo desvinculado do ordenamento jurídico e arraigado na vontade do regulador para a prática de favorecimentos, perseguições, ou ainda, para proveito pessoal.

Contudo, a existência de múltiplos interesses legítimos contrapostos e a ampla discricionariedade do regulador para a ponderação e definição da ordem e intensidade de

\footnotetext{
${ }^{199}$ Agências Reguladoras e a Evolução do Direito Administrativo Econômico, p. 365.

${ }^{200}$ Fundamentos para uma Codificação do Direito Econômico, p. 94-95.

${ }^{201}$ O Problema da Captura das Agências Reguladoras Independentes, p. 169.
} 
prevalência entre esse importa - há de se reconhecer - em um maior risco de cometimento de arbitrariedades (ou captura) por parte do regulador.

Esta realidade do Estado Contemporâneo informa que o regulado está sujeito, de maneira indesviável, ao alvedrio do regulador, isto é, o regulado encontra-se em condição de hiposuficiência em face de decisões regulatórias discricionárias desparametrizadas.

Comprovar, todavia, a ocorrência de arbitrariedades do regulador ao longo do processo decisório e, bem assim, na própria decisão regulatória discricionária não é tarefa fácil, uma vez que não existem parâmetros concretos e objetivos que permitam o acompanhamento da formação da decisão e a sua confrontação pelos interessados e pelos órgãos de fiscalização. A esse fim dedicamos essa dissertação de mestrado.

Antes, porém, é imperioso que se verifique na prática como as Agências Reguladoras atuam diante da necessidade de mediação ativa de interesses legítimos contrapostos. Para isso tomaremos como objeto de análise a ANATEL. 


\section{CAPÍTULO III - A DISCRICIONARIEDADE DA AGÊNCIA REGULADORA NACIONAL DE TELECOMUNICAÇÕES - ANATEL NOS PROCESSOS DECISÓRIOS SOBRE TRANSFERÊNCIA DE CONTROLE DE OPERADORAS DE SERVIÇOS DE TELECOMUNICAÇÕES: ESTUDO DE CASOS}

\section{Introdução.}

No capítulo anterior nos esforçamos para demonstrar o risco real, no Estado Contemporâneo, de que a discricionariedade transmude-se em arbitrariedade com o ultrapassar da tênue linha divisória entre a prevalência dos interesses legítimos de uns e não os de outros.

Este capítulo situa a Agência Nacional de Telecomunicações - ANATEL no cerne da dissertação, na medida em que é nosso intuito focar a discussão do exercício da discricionariedade nos processos decisórios, de mediação ativa de interesses, dessa Agência Reguladora.

A ANATEL, como se sabe, consagrou-se como uma das primeiras Agências Reguladoras Federais resultantes da concretização da nova concepção de Estado Regulador na segunda metade da década de noventa. A complexidade de sua estrutura e organização interna e a amplitude de seus instrumentos de regulação lhe valeram protagonizar uma infinidade de trabalhos acadêmicos e jurídicos ao seu respeito.

Desde a sua criação a ANATEL sempre esteve em pauta. ${ }^{202}$ Por hora, 14 anos após a sua criação, entendemos que o tema do manejo de sua discricionariedade na mediação ativa de interesses vinculados direta e indiretamente ao setor de telecomunicações tem lugar. Isso porque, ao longo dos anos, parece-nos que a ANATEL apresenta um agir cada vez mais subjetivo e desprendido de critérios sólidos e transparentes. A ANATEL aparentemente tornou-se, com o passar dos anos, mais e mais

\footnotetext{
${ }^{202}$ Por vezes, a ANATEL serviu de modelo à análise de questões próprias das Agências Reguladoras e, por outras, esteve propriamente na berlinda, quer seja por razões de ordem administrativa (como, por exemplo, na discussão do regime de seus funcionários), quer seja por razões de política regulatória (como, por exemplo, em face do desenvolvimento do Plano Nacional de Banda Larga - PNBL).
} 
imprevisível. Não há nada mais contraditório às finalidades da moderna regulação do que uma Agência Reguladora que semeia a incerteza, a insegurança e a imprevisibilidade de suas decisões no setor regulado.

O objetivo deste capítulo é, portanto, procurar diagnosticar, através de estudo de casos, quais os parâmetros utilizados pela ANATEL no manejo de seu poder discricionário, isto é, intentamos desvendar quais são os critérios para as escolhas públicas realizadas pela Agência Reguladora, por um interesse em detrimento de outro, em situações em que a mediação ativa de interesses contrapostos lhe é exigida; em caso de ausência de balizas decisórias e de aleatoriedade das razões de decisão da ANATE. Entretanto, intentaremos apreender com a casuística estudada e, a partir desse estudo de casos, construir parâmetros concretos e objetivos que possibilitem o acompanhamento e controle das decisões regulatórias discricionárias da ANATEL por todos os interessados e pelos órgãos de fiscalização.

Para tanto, este capítulo é dividido em duas partes. A Parte I destina-se a um brevíssimo apontamento da origem e competências (III. I. 1. 1), poder decisório e discricionariedade da ANATEL (III. I. 1. 2). A Parte II presta-se, então, ao estudo de casos da Agência Reguladora com vistas a comprovar ou afastar nossas impressões acerca do agir discricionário da ANATEL.

\section{PARTE I}

ANATEL

\section{I. 1. A Agência Reguladora Nacional de Telecomunicações - ANATEL.}

\section{I. 1. 1. Origem e Competências.}

A Lei n. ${ }^{\circ}$ 9.472/1997 criou A ANATEL ${ }^{203}$, entidade integrante da Administração Pública Federal indireta, submetida ao regime autárquico especial ${ }^{204} \mathrm{e}$ vinculada ao ${ }^{203}$ Para uma introdução à Agência Reguladora e ao setor de telecomunicações sugerimos os artigos Direito
das Telecomunicaços e ANATEL, de Floriano de Azevedo MARQUES NETO; e A Agência Nacional de
Telecomunicações, de Benedicto Porto MACEDO. Meu Depoimento e Avaliação sobre a Lei Geral de 
Ministério das Comunicações, com a função de órgão regulador do setor de telecomunicações $\left(\operatorname{art.} 8^{\circ}\right){ }^{205}$

O art. 19 da Lei n. ${ }^{\circ}$ 9.472/1997 (Lei Geral de Telecomunicações - LGT) fixa as competências da Agência Reguladora de maneira geral em seu caput e, em seguida, em seus incisos, específica trinta e uma de suas atribuições.

Em linhas gerais, compete à ANATEL adotar as medidas necessárias para o atendimento do interesse público e para o desenvolvimento das telecomunicações brasileiras, atuando com independência, imparcialidade, impessoalidade e publicidade. ${ }^{206}$

Em termos específicos, compete à Agência Reguladora, dentre outras atribuições, implementar a política nacional de telecomunicações, expedir normas quanto à outorga, prestação e fruição de serviços de telecomunicações, editar atos de outorga e extinção de direito de exploração de serviços de telecomunicações, controlar, acompanhar e proceder à revisão de tarifas, celebrar e gerenciar os contratos de concessão e termos de autorização setoriais, fiscalizar as atividades no setor, deliberar acerca da interpretação da legislação de telecomunicações e sobre os casos omissos, compor administrativamente conflitos de interesses entre prestadoras de serviços de telecomunicações e reprimir infrações aos direitos dos usuários.

A grande diversidade das competências atribuídas por lei à ANATEL não é sem razão. Com efeito, a multiplicidade de funções e competências é própria da atividade regulatória. A partir do momento em que o Estado opta por intervir na ordem econômica como regulador, assume-se o compromisso de manejar todos os instrumentos necessários para, naquele setor da economia, atingir as finalidades precípuas da regulação. A regulação

Telecomunicações de Carlos Ari SUNDFELD. Eduardo Augusto de Oliveira RAMIRES. Direito das Telecomunicações: A Regulação para a Competição.

${ }^{204}$ Tal como esclarece o $\$ 2^{\circ}$ do art. $8^{\circ}$ da Lei, a natureza de autarquia especial conferida à Agência Reguladora é caracterizada por independência administrativa, ausência de subordinação hierárquica, mandato fixo e estabilidade de seus dirigentes e autonomia financeira.

${ }^{205}$ Para conhecer de maneira rápida a história do setor de telecomunicações brasileiro até os dias atuais ver nosso Telecomunicações. Doutrina, Jurisprudência, Legislação e Regulação Setorial, em co-autoria com Floriano de Azevedo MARQUES NETO, p. 21-31.

${ }^{206}$ Acerca da divisão de competências entre Poder Executivo e ANATEL no setor de telecomunicações ver também nosso Telecomunicações. Doutrina, Jurisprudência, Legislação e Regulação Setorial, em coautoria com Floriano de Azevedo MARQUES NETO, p. 34 e ss. 
leva à concentração de funções dado o seu caráter pragmático e finalístico. Para tanto, é necessário que a Agência reguladora detenha amplos e efetivos instrumentos de ação. ${ }^{207}$

\section{I. 1. 2. Discricionariedade e Processo Decisório.}

A ANATEL, como se sabe, detém poder discricionário para atuação no setor de telecomunicações.

Em matéria de regulação, especialmente, a atribuição de margens de liberdade às Agências Reguladoras para a escolha dos instrumentos de ação estatal é essencial. Por uma, porque os setores sujeitos à regulação setorial são em geral dotados de elevada complexidade e especialidade. Por outra, porque é inerente à atividade regulatória a permanente busca do equilíbrio (diria mesmo arbitramento) de interesses internos ao sistema regulado $^{208}$ (públicos e privados) e, bem assim, a mediação ativa de interesses legítimos contrapostos.

A ANATEL, ademais, conquanto ente da Administração Pública se sujeita aos mesmos controles a que a Administração Pública está submetida ${ }^{209}$, inclusive ao controle judicial, como veremos no Capítulo IV.

A Agência Reguladora, ainda em decorrência de sua condição de ente da Administração Pública indireta está adstrita à Lei de Processo Administrativo Federal, Lei n. ${ }^{\circ} 9.784 / 1999$ e, nessa ordem, tem o dever de decidir ${ }^{210}$ explicitamente os processos administrativos e as solicitações que lhe forem apresentadas em matéria de sua competência (art. 48 da Lei n. ${ }^{\circ}$ 9.784/1999), dentre outras obrigações e procedimentos fixados nesta Lei que são diretamente aplicáveis à Agência Reguladora.

O órgão decisório superior da ANATÉL é o Conselho Diretor. Este órgão, composto por cinco conselheiros, decide por maioria absoluta as questões setoriais que lhe são apresentadas (art.20 da Lei n. ${ }^{\circ}$ 9.472/1997).

\footnotetext{
${ }^{207}$ Cf. Floriano de Azevedo MARQUES NETO. Agências Reguladoras Independentes - Fundamentos e seu Regime Jurídico, p. 48.

${ }^{208}$ Cf. Floriano de Azevedo MAQUES NETO. Discricionariedade e Regulação Setorial - O Caso do Controle dos Atos de Concentração por Regulador Setorial, p. 574.

209 Floriano de Azevedo MARQUES NETO afirma que é fundamental que a atividade regulatória seja submetida a esse controle com algum temperamento e adequação às especificidades da atividade regulatória como expõe em seu Pensando o Controle da Atividade de Regulação Estatal, p. 200 e ss.

${ }^{210}$ A decisão da ANATEL deve observar, ademais, os requisitos fixados na Lei de Processo Administrativo, especialmente acerca da sua motivação, como trataremos no capítulo derradeiro da dissertação.
} 
As competências do Conselho Diretor da ANATEL são amplas, dentre as quais se destacam: editar normas sobre matérias de sua competência, aprovar editais de licitação, homologar adjudicações, decidir pela aprovação, transferência, intervenção e extinção das outorgas para prestação de serviços de telecomunicações (art. 22 da Lei n. ${ }^{\circ}$ 9.472/1997). ${ }^{211}$

O processo decisório da ANATEL é longo e conta com pareceres técnicos das diversas áreas da Agência Reguladora ${ }^{212}$. Após o trâmite regulamentar de instrução dos processos administrativos instaurados junto à $\mathrm{ANATEL}^{213}$, estes são remetidos ao Conselho Diretor, onde, depois de distribuídos entre seus integrantes, passa a ser relatado por um de seus conselheiros. ${ }^{214}$

O Conselho Diretor da ANATEL possui três fóruns de deliberação e decisão: as sessões, reuniões e circuitos deliberativos (art. $4^{\circ}$ do Regimento Interno da ANATEL). Em todos eles os conselheiros manifestam o seu voto, de maneira mais ou menos, detalhada.

Das decisões do Conselho Diretor ${ }^{215}$, cabe recurso administrativo e pedido de reconsideração para o próprio Conselho Diretor (art. 82 do Regimento Interno da ANATEL) ${ }^{216}$, instância máxima recursal da Agência Reguladora (art. 84, §1 ${ }^{\circ}$ do Regimento Interno da ANATEL). ${ }^{217}$

\footnotetext{
${ }^{211}$ O rol exaustivo e detalhado das competências do Conselho Diretor da ANATEL pode ser encontrado no ar. 175 do Regimento Interno da Agência Reguladora (Resolução n. . 270/2001).

${ }^{212}$ A ANATEL tem sua estrutura organizacional dividida em superintendências e essas subdivididas em gerências. Esta divisão de competências pode ser consultada a partir do art. 102 do Regimento Interno da ANATEL (Resolução n. ${ }^{\circ}$ 270/2001) e, bem assim, as atribuições de cada superintendência e gerência a partir do art. 135 do mesmo instrumento normativo. As superintendências e gerências emitem Informes acerca das matérias que lhe são submetidas. Esses documentos basicamente analisam os aspectos específicos - de acordo com a atribuição de cada superintendência ou gerência - de cada caso que lhes é submetido.

${ }^{213}$ Para conhecer os processos administrativos que podem tramitar junto à ANATEL e, bem assim, o seu funcionamento ver nosso Telecomunicações. Doutrina, Jurisprudência, Legislação e Regulação Setorial, em co-autoria com Floriano de Azevedo MARQUES NETO, p. 83 e ss.

${ }^{214}$ Este relato origina a Análise do Conselheiro Relator, onde os argumentos da decisão a ser por este tomada são apresentados.

${ }^{215}$ São irrecorríveis os atos de mero expediente ou preparatórios das decisões, os informes e pareceres (art. 85 do Regimento Interno da ANATEL).

${ }^{216}$ Acerca da tramitação do recurso administrativo ver art. 90 do Regimento Interno da ANATEL.

${ }^{217}$ Existe discussão acerca da possibilidade de interposição de recurso hierárquico das decisões do Conselho Diretor. Tal como Floriano se Azevedo MARQUES NETO, entendemos não ser compatível com o modelo de moderna regulação estatal, exercida por meio de entes independentes e autônomos, que haja sobre a atividade regulatória mecanismos de controle hierárquico. Pensando o Controle da Atividade de Regulação estatal, p. 243. O que não afasta, de maneira nenhuma, a possibilidade de se recorrer ao controle judicial da decisão regulatória.
} 
Situada, assim, de maneira bastante breve a ANATEL, especialmente em seus aspectos que nos interessam nessa dissertação, discricionariedade e poder decisório, passamos ao estudo de casos proposto.

\section{PARTE II}

\section{Estudo de Casos}

\section{II. 1. Estudo de Casos.}

O estudo de casos revela-se como uma importante ferramenta empírica para a compreensão de ações e comportamentos complexos cujo entendimento não é imediato.

Robert YIN bem sintetizou a utilidade dessa ferramenta: "O estudo de casos é uma forma de se fazer pesquisa social empírica ao investigar-se um fenômeno atual dentro do seu contexto de vida-real, onde as fronteiras entre o fenômeno e o contexto não são claramente definidas e na situação em que múltiplas fontes de evidência são usadas." 218

Marcos CAMPOMAR complementa, ainda, a serventia do estudo de casos para fins acadêmicos: "O estudo intensivo de um caso permite a descoberta de relações que não seriam encontradas de outra forma, sendo as análises e inferências em estudo de casos feitas por analogia de situações respondendo principalmente às questões por quê?? E como?". 219

O estudo de casos apresentado a seguir realizou-se, pois, na busca dos por quês e como a ANATEL decide, in concreto, situações que contrapõem interesses legítimos em conflito e, nas quais, a Agência Reguladora deve manejar o poder discricionário de que dispõe para ditar a prevalência ou o detrimento de um ou de outro destes interesses.

Procurou-se investigar os critérios e as razões de decisão da Agência Reguladora, a fim de constatar-se a existência de parâmetros objetivos e concretos que permitam o acompanhamento dos interessados ao longo do processo decisório e a confrontação, caso necessário, em âmbito judicial, do exercício do poder discricionário do

\footnotetext{
${ }^{218}$ YIN, Robert K.. Case study research: design and methods, p. 19.Tradução nossa.

${ }^{219}$ Marcos Cortez CAMPOMAR. Do uso de 'estudo de caso' em pesquisas para dissertações e teses em administração. Revista de Administração. São Paulo, p.95-97.
} 
regulador diante da mediação dos interesses envolvidos nas operações que lhe são submetidas.

Esta busca teve por finalidade, ademais, verificar a previsibilidade e a confiabilidade das decisões discricionárias da ANATEL e, para tanto, nos valemos do universo dos casos de transferência de controle de operadoras de serviços de telecomunicações.

\section{II. 2. Metodologia de Pesquisa dos Precedentes da ANATEL.}

\section{II. 2. 1. Corte Metodológico.}

Com mais de dez anos de atuação na regulação do setor de telecomunicações brasileiro, a casuística da ANATEL é vasta e diversificada.

Optou-se, assim, em realizar corte metodológico temático para o direcionamento do estudo de casos, considerando que, para a nossa análise relativa ao exercício do poder discricionário pela ANATEL, seria imprescindível buscar assuntos nos quais se constatasse a existência de situações em que conflitassem interesses legítimos. Essas circunstâncias seriam propícias, pois, para a identificação dos critérios e parâmetros de sopesamento dos interesses legítimos contrapostos e para a aferição das razões de decisão da Agência Reguladora. ${ }^{220}$

Com base neste pressuposto, selecionou-se o tema das transferências de controle $^{221}$ de operadoras de serviços de telecomunicações ${ }^{222}$, como universo de pesquisa, uma vez que se constatou que esse conjunto abarcava precedentes em que se contrapunham interesses legítimos e que, dentre estes, a Agência Reguladora discricionariamente

\footnotetext{
${ }^{220}$ Parece-me que a questão está limitada às situações em que se verifica a existência de mais de um interesse legítimo contraposto. Isso porque se são legítimos e não contrapostos me é instintivo que o Estado deva promover a ambos.

${ }^{221}$ Acerca do conceito de controle no direito regulatório ver a precisa lição de Floriano de Azevedo Marques em seu Discricionariedade e regulação setorial - $O$ caso do controle dos atos de concentração por regulador setorial, p.569.

${ }^{222}$ Para uma introdução ao Regulamento para Apuração de Controle e Transferência de Controle de Empresas Prestadoras de Serviços de Telecomunicações (Resolução n. ${ }^{\circ}$ 101/1999), instrumento basilar que rege a matéria, ver A primeira década da Resolução n. ${ }^{\circ}$ 101/1999 da Anatel: a década da provação do regulamento de controle, p. 43-71.
} 
escolheu o prevalecente e, ora e vez, optou, ainda, por fixar medidas acautelatórias ${ }^{223}$, condicionamentos e contrapartidas ${ }^{224}$ às aprovações concedidas.

\section{II. 2. 2. Critérios de Pesquisa.}

A pesquisa de precedentes da ANATEL realizou-se no site oficial da Agência Reguladora ( mais genérica, a pesquisa avançada e, a outra mais específica, a pesquisa no acervo documental da biblioteca.

A pesquisa realizada diretamente na base de dados da biblioteca da ANATEL permitiu-nos acessar diretamente as Análises e Votos dos membros de seu Conselho Diretor e os Atos de decisão desse colegiado.

A pesquisa avançada, por sua vez, propiciou-nos identificar vestígios (Notas à Imprensa, Informes, Pareceres da Procuradoria, Atas das Reuniões do Conselho Diretor, Despachos, Atos, Análises correlatas) de precedentes de operações de conhecimento público, mas cujas Análises e Votos não se encontravam disponíveis no site da ANATEL. Com as informações constantes de tais vestígios de precedentes (número de processo administrativo, data e número da reunião de deliberação do Conselho Diretor, especialmente), pudemos, então, requerer eletronicamente à biblioteca da ANATEL,

223 A ANATEL utiliza-se do art. 72, parágrafo único da Resolução n. ${ }^{\circ}$ 270/2001 (Regimento Interno) como base normativa a justificar a imposição de medidas acautelatórias nas operações que lhe são submetidas, embora tal dispositivo esteja alocado na Seção X, do Regimento Interno, atinente especificamente aos procedimentos para apuração de descumprimento de obrigações. O texto da norma é precisamente o seguinte “Art. 72, parágrafo único. No curso do procedimento ou, em caso de risco iminente, antes dele, a Agência Reguladora poderá, motivadamente, adotar medidas cautelares, estritamente indispensáveis para evitar lesão, sem a prévia manifestação do interessado." Não é, entretanto, nosso objetivo neste trabalho discorrer sobre a matéria.

${ }^{224}$ Vale, desde já um esclarecimento a respeito da convivência entre os condicionamentos e contrapartidas impostos pela ANATEL. A imposição de condicionamentos é justificada pela ANATEL com base legal, no art. 71 da LGT, in verbis: "Art. 71. Visando a propiciar competição efetiva e a impedir a concentração econômica no mercado, a Agência Reguladora poderá estabelecer restrições, limites ou condições a empresas ou grupos empresariais quanto á obtenção e transferência de concessões, permissões e autorizações." (grifos nossos) O texto legal é claro ao autorizar a Agência Reguladora a restringir/limitar ou condicionar as operações que resultem na transferência das outorgas de serviços de telecomunicações. É silente, entretanto, no que concerne à imposição de contrapartidas às operadoras envolvidas nas operações e aos seus respectivos grupos econômicos. Constatamos, contudo, ao estudar a casuística apresentada nesse capítulo, que sob o título de condicionamento a ANATEL impôs, em algumas operações, verdadeiras contrapartidas a sua aprovação. De modo que, para fins desse trabalho, ainda que sem base legal (o que seria tema próprio para um outro trabalho), faremos a distinção entre condicionamentos e contrapartidas, considerando abarcados no primeiro, as condições relacionadas diretamente com o objeto da operação e, pois, no segundo, as compensações desvinculadas em absoluto das operações, requeridas pela Agência Reguladora para a aprovação dessas. 
através da ferramenta do Fale Conosco - Solicitação de Vistas e Cópias de Documentos, às Análises basilares e os Votos proferidos nos precedentes buscados.

Deste modo, a pesquisa realizada, com buscas cruzadas nas duas ferramentas disponíveis no site da ANATEL, permitiu-nos abarcar margem maior de ocorrências, para além daquelas arquivadas eletronicamente no acervo documental da Biblioteca da Agência Reguladora. Contudo, deve-se ressalvar que, ainda assim, o universo resultante de nossa pesquisa pode não representar o conjunto absoluto de precedentes da ANATEL referente às operações de transferência de controle. Isto porque não são todos os casos submetidos à aprovação prévia da Agência Reguladora que são publicados e disponibilizados para consulta em seu site. Trata-se de vício de transparência da ANATEL com prejuízo imediato na previsibilidade das decisões da Agência Reguladora e na segurança jurídica dos administrados. Esse tema será abordado com profundidade no Capítulo IV desta dissertação.

Mencionamos acima que a pesquisa realizada buscou identificar três espécies de documentos Análises e Votos dos Conselheiros da ANATEL e Atos de decisão da Agência Reguladora. Essa opção deveu-se ao fato de que se identificou que os dois primeiros instrumentos processuais eram as peças fundamentais para a compreensão dos posicionamentos da ANATEL em cada precedente ${ }^{225}$. As Análises, em verdade, comportam o exame dos fatos, o seu cotejamento com a legislação e regulamentação setorial, apresentação e sopesamento das opiniões das áreas técnicas e Procuradoria Especializada da ANATEL e, ao final, o voto do Conselheiro da Agência Reguladora. Os Votos, per se, refletem a decisão fundamentada de cada Conselheiro da ANATEL. Os Atos, por sua vez, evidenciam, com precisão, a decisão (e os seus limites) do colegiado da Agência Reguladora.

Os termos de busca utilizados foram "transferência de controle", "transferência", "controle", "anuência prévia" e "aprovação prévia", partindo-se da delimitação temática acima referida.

Não houve delimitação temporal da pesquisa; de modo que a busca abrangeu os precedentes da ANATEL existentes e publicados até o mês de julho de 2011.

\footnotetext{
${ }^{225}$ A competência dos Conselheiros da ANATEL para a elaboração de Análises e proferimento de seus votos encontra-se no art. 176, V e IX da Resolução n. ${ }^{\circ}$ 270/2001, Regimento Interno da ANATEL.
} 
A pesquisa inicial apresentou 192 resultados.

Dentre os precedentes levantados foram selecionados, então, aqueles cujas Análises e Votos não eram extremamente resumidos e simplórios e que, por isso, dificultavam a compreensão das razões de decisão da ANATEL ou que não apresentam elementos suficientes para a nossa análise. Assim, após a primeira triagem nos deparamos com 80 precedentes.

Em seguida, os precedentes foram analisados com relação à complexidade da operação submetida à aprovação prévia da ANATEL e, bem assim, com relação à análise regulatória empreendida, em cada caso, pela Agência Reguladora. Os precedentes de menor complexidade fática e, pois, regulatória foram descartados. A segunda triagem resultou em 50 precedentes.

Apuramos por meio das duas triagens iniciais que três temas eram recorrentes na casuística da Agência Reguladora acerca da transferência de controle: as reestruturações societárias internas dos grupos econômicos aos quais pertencem as operadoras de serviços de telecomunicações, os arranjos societários resultantes em participações cruzadas vedadas na legislação e regulamentação setorial e as fusões e aquisições de operadoras de serviços de telecomunicações.

Verificamos, também, que embora encerrassem, na origem, operações de fusões e aquisições de operadoras de serviços de telecomunicações, os casos pautados como reestruturações societárias internas e participações acionárias cruzadas recebiam atenção específica da Agência Reguladora.

Assim sendo, optamos pela divisão dos precedentes resultantes da segunda triagem nos três grupos distintos, a seguir, de acordo com o objeto principal examinado pela Agência Reguladora, a fim de que fossem examinados em suas particularidades: (i) reestruturações societárias internas aos grupos econômicos aos quais pertencem as operadoras de serviços de telecomunicações; (ii) participações societárias cruzadas vedadas entre operadoras de serviços de telecomunicações; e (iii) fusões e aquisições envolvendo operadoras de Serviços de Televisão por Assinatura (Serviço de Distribuição de Sinais de Televisão e de Áudio por Assinatura via satélite - DTH, TV a Cabo, Serviço de Distribuição de Sinais Multiponto Multicanais - MMDS), concessionárias e 
autorizatárias de Serviço Telefônico Fixo Comutado - STFC e de Serviço Móvel Pessoal SMP.

Os três grupos de precedentes foram, assim, analisados de maneira autônoma.

O primeiro grupo contou com 11 precedentes. Constatou-se que os casos de reestruturações societárias internas aos grupos econômicos das operadoras de serviços de telecomunicações, pertencentes ao primeiro grupo de precedentes, não se caracterizavam propriamente como situações de transferência de controle nos termos indicados na Resolução n. ${ }^{\circ}$ 101/1999. Assim, esses precedentes foram descartados.

O segundo grupo apresentou 13 precedentes. Nestes se identificou posicionamento consolidado da ANATEL no sentido de determinar a adoção de medidas acautelatórias às empresas detentoras de participação acionária cruzada vedada, para o fim de preservar o modelo de competição setorial e assegurar os direitos dos usuários dos serviços de telecomunicações. Verificaram-se, ainda, nestes casos, convergência e identidade na aplicação das medidas acautelatórias por parte da ANATEL. Conferiu-se, também, que a existência de participações cruzadas vedadas na legislação e na regulamentação setorial, emoldurou o agir da Agência Reguladora, bordeando o universo de medidas acautelatórias possíveis e vinculando-as especificamente às condutas tipicamente presentes nestas situações. ${ }^{226}$ Por esta razão estes precedentes foram descartados.

O terceiro grupo, por sua vez, resultou com 26 precedentes. Averiguou-se neste grupo de precedentes que diante de operações de fusões e aquisições que envolviam operadoras de serviços de telecomunicações a ANATEL valeu-se de seu poder discricionário para análise e aprovação das operações e, neste agir, portou-se de maneira aleatória. Identificaram-se, nesta medida, dois subgrupos de precedentes. Um composto por 23 casos em que a Agência Reguladora não fixou condicionamentos à aprovação das

\footnotetext{
${ }^{226}$ Dentre as medidas comumente determinadas pela ANATEL, podemos destacar, particularmente: (i) a suspensão dos direitos de voto e veto de membros do Conselho de Administração e/ou Diretoria; (ii) o afastamento efetivo desses membros do Conselho de Administração e/ou Diretoria; (iii) a suspensão dos direitos de indicação e nomeação desses membros a esses órgãos das sociedades; (iii) a proibição de que tais membros participem de deliberações e decisões concernentes especialmente à gestão da controlada ou à matéria de interesse específico da controlada; (iv) a proibição de transferência de informações de caráter competitivo entre controlada e controladora; e (v) a suspensão de acordos de assistência técnica, ou instrumento equivalente, entre controlada e controladora. É de se notar que nenhuma destas disposições se encontra pactuada nas minutas por nós analisadas.
} 
operações e outro com 3 em que a ANATEL as impôs. Apurou-se, então, a origem e a ordem dos condicionamentos fixados pela ANATEL no segundo subgrupo e não se constatou convergência, uniformidade e coerência entre elas. Por essas razões, selecionouse o terceiro grupo de precedentes para o estudo de casos da presente dissertação de mestrado.

Pois bem, dentre os 3 casos do segundo subgrupo do terceiro grupo de precedentes, todos foram selecionados, considerando que, nesses casos, a ANATEL determinou aleatoriamente à adoção de condicionamentos para a aprovação das operações. Esses são os precedentes:

Aquisição do controle do Grupo Brasil Telecom pelo Grupo Oi; Aquisição do controle da Global Village Telecom Holding S.A. pelo Grupo Telefonica; $e$

(iii) Consolidação do controle da Vivo pelo Grupo Telefonica.

Em meio aos outros 23 precedentes, do primeiro subgrupo do terceiro grupo de precedentes, selecionamos 2 casos, com vistas a propiciar a análise comparativa, em nosso estudo de casos, não só entre os precedentes com condicionamentos, mas também entre esses e aqueles em que essas medidas não foram cogitadas pela ANATEL: Os precedentes selecionados, nessa medida, são os seguintes:

(iv) Aquisição do controle da Vésper S.A. e da Vésper São Paulo S.A., pela Empresa Brasileira de Telecomunicações - EMBRATEL; $e$ Aquisição do controle da Intelig Telecomunicações Ltda. pelo Grupo Telecom Italia.

Em linhas gerais, optamos por esses precedentes, dentre tantos outros, porque apresentam operações de mesma ordem com relação àquelas constantes do segundo subgrupo, isto é, são precedentes que envolvem os mesmos serviços de telecomunicações, reconhecidas operadoras de STFC e SMP e importantes grupos econômicos atuantes no setor de telecomunicações brasileiro. Mais que isso, são operações que com características próximas àquelas do segundo subgrupo, uma vez que também se referem a aquisição do 
controle de autorizatárias de STFC e SMP, salvo pelo precedente da fusão das concessionárias de STFC, Oi e BrT, inédito no país.

Especificamente elegemos o precedente (iv) por ser paradigma no que tange aos casos de transferência de controle no setor de telecomunicações. Tal condição deve-se ao fato de que ultrapassada a vedação temporal do art. $202^{227}$ da LGT, abriu-se um novo período de consolidação e reorganização dos players atuantes no mercado de telecomunicações brasileiro, sendo a aquisição da Vésper pela Embratel, o primeiro caso, com essas características, a ser submetido à anuência prévia da ANATEL. Este precedente é, pois, relevante por constituir-se no marco inicial das alterações ao modelo setorial desenhado no processo de desestatização e especialmente porque nesse caso a ANATEL viu-se inauguralmente diante do poder-dever de sopesar os interesses em jogo envolvidos na operação, como veremos no item III, II. 3. adiante.

Selecionamos, ainda, o precedente (iv) por ser posterior ao (i) e anterior ao (ii); de modo que, se tentou reconstruir a evolução do exercício do poder discricionário pela ANATEL nos processos decisórios de transferência de controle de operadoras de serviços de telecomunicações.

\section{II. 2. 3. Forma de Análise dos Precedentes da ANATEL.}

Os precedentes selecionados foram tabulados. Essa ferramenta possibilitou a análise comparativa dos casos e, especialmente a visão de suas semelhanças e diferenças.

A tabulação dos precedentes se deu com base em quatro critérios: (i) existência de vedações legais e/ou regulatórias; (ii) aspectos concorrenciais; (iii) relação com os usuários; e (iv) presença de externalidades.

O primeiro abarcou a identificação de vedações legais e regulatórias específicas às aquisições, fusões, incorporações e operações correlatas que envolvam operadoras de serviços de telecomunicações; a existência de participações cruzadas

${ }^{227}$ De acordo com esse dispositivo a transferência do controle acionário ou da concessão, após a desestatização, somente poderia ocorrer após decorridos cinco anos e desde que superado o óbice do $2^{\circ}$ do art. 10 do Decreto n..$^{\circ}$ 2.543/1998 que impedia a obtenção de novas autorizações, por parte dos titulares de concessão, até 31.12.2003, ou até 31.12.2001, no caso de antecipação das metas de universalização. 
vedadas no setor de telecomunicações; a constatação de sobreposições de outorgas e do acúmulo de códigos de seleção de prestadoras e radiofrequências; e a verificação de potencial prejuízo ao cumprimento das obrigações assumidas nos Contratos de Concessão de STFC e Termos de Autorização de STFC e SMP.

O segundo restringiu-se a avaliação de dano potencial ou efetivo à concorrência.

O terceiro limitou-se a aferição de promoção de benefícios aos usuários.

O quarto, por fim, apontou a presença de produção de externalidades positivas.

Reputamos que estes critérios seriam os mais adequados para a compreensão das razões da ANATEL em suas decisões discricionárias nos precedentes selecionados, na medida em que esses expõem os principais efeitos das operações submetidas à Agência Reguladora e que são, ordinariamente, apurados e sopesados ao longo de seus processos decisórios.

Ainda na tabulação apresentaremos a decisão da ANATEL e seus condicionamentos e contrapartidas, se houver.

\section{II. 3. Apresentação dos Precedentes.}

Antes, porém, de passarmos à análise dos critérios e das razões de decisão da ANATEL em cada um dos precedentes selecionados, cumpre-me apresentá-los, de maneira breve, com vistas a propiciar a melhor compreensão das operações submetidas à Agência Reguladora.

Aquisição do controle da Vésper S.A. e da Vésper São Paulo S.A., pela Empresa Brasileira de Telecomunicações - EMBRATEL.

Tratou-se da aquisição do controle das empresas Vésper S.A. e Vésper São Paulo S.A. (em conjunto, Vésper) pela Empresa Brasileira de Telecomunicações S.A. (Embratel). ${ }^{228}$

${ }^{228}$ Processo n. ${ }^{\mathrm{o}} 53500.005054 / 2003$. 
Esta operação constituiu-se no primeiro movimento espontâneo do mercado que alterou a configuração do modelo setorial instituído no processo de desestatização e implementado por meio do Decreto n. ${ }^{\circ}$ 2.534/1998, haja vista que a Vésper São Paulo S.A., empresa-espelho da Telesp, na Região III do PGO, e a Vésper S.A., empresa-espelho da operadora do Grupo Telemar, na Região I do PGO, restariam absorvidas pela Embratel.

A aquisição da Vésper pela Embratel tornou-se possível na medida em que a concessionária antecipou o cumprimento de suas metas de universalização e expansão na Região IV do PGO; de modo que, a partir de 31/12/2001, atendidas as condições do $\S 2^{\circ}$ do art. 10 do PGO e, uma vez não existindo mais qualquer limitação ao número de prestadoras de STFC por Região do PGO (art. 10, caput, do PGO), a operação pode ser submetida à aprovação da ANATEL.

O pioneirismo dessa operação também se verificou no que diz respeito à regularização de sobreposições de outorgas, por meio de sua consolidação, no prazo de 18 (dezoito) meses, esta solução passou, a partir de então, a ser adotada, na qualidade de condicionamento às operações, sempre que necessária a desincompatibilização de outorgas e, após, com a solidificação da casuística da Agência Reguladora restou positivada. ${ }^{229}$

A ANATEL aprovou a operação exclusivamente com esse condicionamento. ${ }^{230}$

A aprovação ocorreu por unanimidade vide Ata da Reunião n. ${ }^{\circ}$ 278, de 19/11/2003.

(ii) Aquisição do controle da Intelig Telecomunicações Ltda. pelo Grupo Telecom Italia.

Cuidou-se de operação de aumento de capital seguida de transferência de controle da Intelig Telecomunicações S.A. (Intelig) para o Grupo Telecom Italia. ${ }^{231}$

A Intelig é a empresa-espelho, de STFC, da Embratel, na Região IV do PGO. Esta operação implicou, assim, na absorção da última empresa-espelho tal como desenhado o modelo setorial à época da desestatização.

\footnotetext{
${ }^{229}$ Art. $6^{\circ}, 4^{\text {o }}$ do Decreto n. ${ }^{\circ}$ 6.654/2008, Novo Plano Geral de Outorgas.

${ }^{230}$ Análise n. ${ }^{\circ} 003 / 2003-G C M B$, de 18/11/2003 e Ato n. ${ }^{\circ} 40.812$, de 24/11/2003.

${ }^{231}$ Processo n. ${ }^{\text {5 } 3500.008646 / 2009 . ~}$
} 
Especificamente, nesse caso, a infraestrutura construída pela Intelig para o provimento do STFC, em âmbito nacional, rendeu-lhe o interesse dos grupos econômicos consolidados no setor de telecomunicações brasileiro.

A ANATEL concedeu anuência prévia ${ }^{232}$ à operação com a imposição de condicionamento exclusivo quanto à regularização das sobreposições de outorgas. ${ }^{233}$

A aprovação da operação ocorreu por unanimidade nos termos da Ata da Reunião n. ${ }^{\circ}$ 531, de 06/08/2009, do Conselho Diretor.

Cuidou-se de uma série de operações societárias destinadas à aquisição do controle acionário indireto da Brasil Telecom S.A., 14 Brasil Telecom Celular S.A., Vant Telecomunicações S.A., Brasil Telecom Cabos Submarinos Ltda. e Brasil Telecom Comunicação Multimídia Ltda,, detido pela Brasil Telecom Participações S.A., Solpart Participações S.A., Invitel S.A., Opportunity ${ }^{234}, \mathrm{CVC}^{235}$ e investidores institucionais ${ }^{236}$, pela Telemar Norte Leste S.A. ${ }^{237}$

A operação condicionou-se, em um primeiro momento, à publicação do Decreto n. ${ }^{\circ}$ 6.654, de 20/11/2008, que aprovou o novo Plano Geral de Outorgas (Novo PGO), no qual se autorizou a transferência da concessão e do controle acionário das concessionárias de STFC e, bem assim, que pertencessem a um mesmo grupo econômico, concessionárias atuantes em até duas regiões do PGO. ${ }^{238}$ Posteriormente, a partir do início da vigência do Novo PGO, a operação pode ser concretizada.

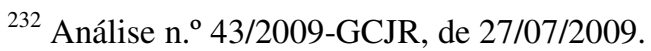

${ }^{233}$ Ato n. ${ }^{\circ} 4.634$, de 11/08/2009.

234 Opportunity Fund, Opportunity Lógica Rio Consultoria e Participações Ltda., Opportunity Asset Administradora de Recursos de Terceiros Ltda., Opportunity Invest II Ltda., Opportunity Investimentos Ltda., Opportunity I Fundo de Investimento em Ações, Opportunity Lógica II Fundo de Investimento em Ações, International Market Investiments, C.V., Luxor Fundo de Investimento Multimercado e Timepart Participações Ltda.

${ }^{235}$ Citigroup Venture Capital International Brazil, L. P., Priv Fundo de Investimento em Ações e Tele Fundo de Investimento em Ações.

${ }^{236}$ Fundo de Investimento em Participações (IIFIP), Caixa de Previdência dos Funcionários do Banco do Brasil - PREVI, Fundação 14 de Previdência Privada, Fundação Petrobras de Seguridade Social - PETROS, Fundação Embratel de Assistência e Seguridade Social - TELOS e Fundação dos Economiários Federais FUNCEF.

${ }^{237}$ Processo n. ${ }^{\circ} 53500.030759 / 2008$.

${ }^{238}$ Art. $6^{\circ}$, caput, $\S 1^{\circ}$ e $\S 2^{\circ}$.
} 
A operação propiciou a união de dois grupos econômicos atuantes, no setor de telecomunicações, em todo o território nacional e, especialmente, na condição de concessionários de STFC nas Regiões I (Grupo Telemar) e II (Grupo Brasil Telecom) do PGO.

A operação envolveu, ainda, operadoras de STFC, SMP, SCM, Televisão por Assinatura e satélite.

Essa operação não encontra precedentes no setor de telecomunicações e, em razão da importância de seus impactos neste segmento, mereceu cuidadosa atenção da Agência Reguladora, do Presidente da República, do Ministério das Comunicações, dos demais players do mercado e da opinião pública.

A ANATEL aprovou a operação com condicionamentos ${ }^{239}$. As condições impostas neste caso originaram-se de compromissos voluntários apresentados pelos interessados. Os termos iniciais da proposta apresentada à Agência Reguladora sofreram algumas modificações e inclusões da ANATEL e foram, então, transformadas em condicionamentos $^{240}$ à operação.

A decisão de aprovação da operação ocorreu por maioria de votos, $3 \times 1$, sendo vencido o Conselheiro Plínio de Aguiar Jr. e ocorrendo discordância da Conselheira Emília Ribeiro quanto aos temas da neutralidade de redes e do backhaul, questões em que foi vencida pelos Conselheiros Ronaldo Porto Sardenberg e Antonio Domingos Teixeira Bedran, nos termos da Ata da Reunião n. ${ }^{\circ}$ 507, de 17/12/2008, do Conselho Diretor ${ }^{241}$.

(iv) Aquisição do controle da Global Village Telecom Holding S.A. pelo Grupo Telefônica.

Tratou-se de operação relativa à aquisição do controle acionário da GVT Holding S.A., controladora direta da Global Village Telecom Ltda. (em conjunto, GVT),

\footnotetext{
${ }^{239}$ Ato n. ${ }^{\circ} 7.828 / 2008$.

240 Esses condicionamentos eram em verdade contrapartidas à aprovação da operação tal como já esclarecemos anteriormente.

${ }^{241}$ Análise n. ${ }^{\circ}$ 130/2008-GCER, de 12/12/2008 e Voto s/ número do Conselheiro Ronaldo Porto Sardenberg, de $17 / 12 / 2008$.
} 
pelo Grupo Telefônica, por meio de oferta pública voluntária de aquisição de ações ordinárias. $^{242}$

A GVT, originariamente, é a empresa-espelho da concessionária de STFC do Grupo Brasil Telecom, na Região II do PGO. Isto é, a GVT, na condição de autorizatária, presta STFC, em regime privado, nesta região, enquanto, paralelamente, a Brasil Telecom S.A. presta o mesmo serviço em regime público, por meio de concessão.

A operação não se concretizou, pois, paralelamente, o Grupo Vivendi adquiriu o controle acionário da GVT.

Ambos os grupos econômicos requereram a anuência prévia à ANATEL. A Agência Reguladora entendeu existir conexão entre os processos e os decidiu conjuntamente.

A ANATEL concedeu anuência prévia aos dois grupos econômicos. ${ }^{243}$

A Agência Reguladora não impôs qualquer condicionamento ao Grupo Vivendi $^{244}$ para a aprovação da operação, mas os fixou ${ }^{245}$ para o Grupo Telefônica. ${ }^{246}$

A decisão do Conselho Diretor ocorreu por 3 votos a 1, vide Ata da Reunião n. ${ }^{\circ}$ 544, de 12/11/2009. Voto divergente da Conselheira Emília Ribeiro n. 049/2009-GCER, de 12/11/2009, propondo a restituição dos autos às áreas técnicas competentes para a formulação de condicionamentos tanto ao Grupo Vivendi, quanto ao Grupo Telefonica, observada a isonomia e, posteriormente, à Procuradoria Especializada da ANATEL para análise das questões legais cabíveis.

Consolidação do Controle da Vivo pelo Grupo Telefônica.

Tratou-se de operação para a aquisição pelo Grupo Telefônica da totalidade da participação acionária da Vivo Participações. ${ }^{247}$

\footnotetext{
${ }^{242}$ Processo n. $^{\text {o } 53500.022645 / 2009}$ e Processo n. ${ }^{\mathrm{o}}$ 53500.023251/2009 (Anexado).

${ }^{243}$ Análise n. ${ }^{\circ}$ 642/2009-GCAB, de 06/11/2009.

${ }^{244}$ Ato n. ${ }^{\circ} 6.553$, de 13/11/2009.

${ }^{245}$ Idem nota 112 .

${ }^{246}$ Ato n. ${ }^{\circ} 6.549$, de 13/11/2009.

${ }^{247}$ Processo n. ${ }^{\circ}$ 53500.018772/2010.
} 
O Grupo Telefonica até então compartilhava o controle do Grupo Vivo com o Grupo Portugal Telecom, ambos, com 50\% do capital acionário a Brasilcel, controladora da Vivo Participações S.A. A operação representou, nessa medida, a consolidação do controle do Grupo Vivo pelo grupo espanhol.

Nesse caso, o Grupo Vivo propôs à Agência Reguladora a implementação de compromissos voluntários. Estes foram aceitos, alterados e ampliados pela Agência Reguladora que os transformou, ademais, em condicionamentos à operação. ${ }^{248}$

A decisão do Conselho Diretor ocorreu por maioria de quatro votos, sendo contrária a Conselheira Emília Maria Silva Ribeiro Curi, Voto n. ${ }^{\circ}$ 65/2010 - GCER, de 23/09/2010, que propôs a não aceitação dos compromissos voluntários apresentados pelos interessados e à consulta de sua pertinência às áreas técnicas da Agência Reguladora, nos termos da Ata da 580ª Reunião do Conselho Diretor da ANATEL.

\section{II. 4. Análise dos Precedentes.}

A análise dos precedentes apresentada a seguir é divida em três etapas para fins didáticos.

A análise comparativa dos critérios de decisão da ANATEL nos precedentes selecionados será apresentada, na forma de tabulação, na primeira etapa. Os dados tabulados serão, então, analisados objetivamente. ${ }^{249}$

Os condicionamentos e contrapartidas impostos pela ANATEL em cada um dos precedentes serão, em seguida, apresentados, também na forma de tabulação e acompanhados de apreciação objetiva, na segunda etapa. ${ }^{250}$

Ao final, na terceira etapa, as informações expostas nas etapas anteriores serão examinadas de maneira conjunta e global, considerando a fundamentação, ou a ausência dessa, nas Análises que motivaram as decisões da Agência Reguladora em cada precedente.

\footnotetext{
${ }^{248}$ Idem nota 112.

${ }^{249}$ Esse exame realizou-se com base nas Análises e Votos dos Conselheiros da ANATEL.

${ }^{250}$ Essa análise empreendeu-se, para além das Análises e Votos dos Conselheiros da ANATEL, com a apuração do teor dos Atos de decisão de cada precedente estudado.
} 
III. II. 4. 1. Os Critérios de Decisão da ANATEL.

A tabela a seguir sintetiza os critérios de decisão da ANATEL apurados nos precedentes estudados. 


\section{TABELA 1}

Os Critérios de Decisão da Anatel

\begin{tabular}{|c|c|c|c|c|c|}
\hline Critério/Caso & BrT- Oi & Tlf-Vivo & Tlf - GVT & Vésper - EBT & TIM - Intelig \\
\hline \multirow[t]{2}{*}{$\begin{array}{c}\text { Vedações Legais e } \\
\text { Regulatórias }\end{array}$} & $\begin{array}{c}\text { Óbice do art. } 8^{\circ} \text { PGA } \\
- \text { SMP }\end{array}$ & -- & --- & $\begin{array}{c}\text { Óbice do art. } 68 \mathrm{da} \\
\text { LGT }\end{array}$ & -- \\
\hline & $\begin{array}{l}\text { Sobreposição de } \\
\text { outorgas }\end{array}$ & --- & $\begin{array}{l}\text { Sobreposição de } \\
\text { outorgas }\end{array}$ & $\begin{array}{c}\text { Sobreposição de } \\
\text { outorgas }\end{array}$ & $\begin{array}{c}\text { Sobreposição de } \\
\text { outorgas }\end{array}$ \\
\hline
\end{tabular}




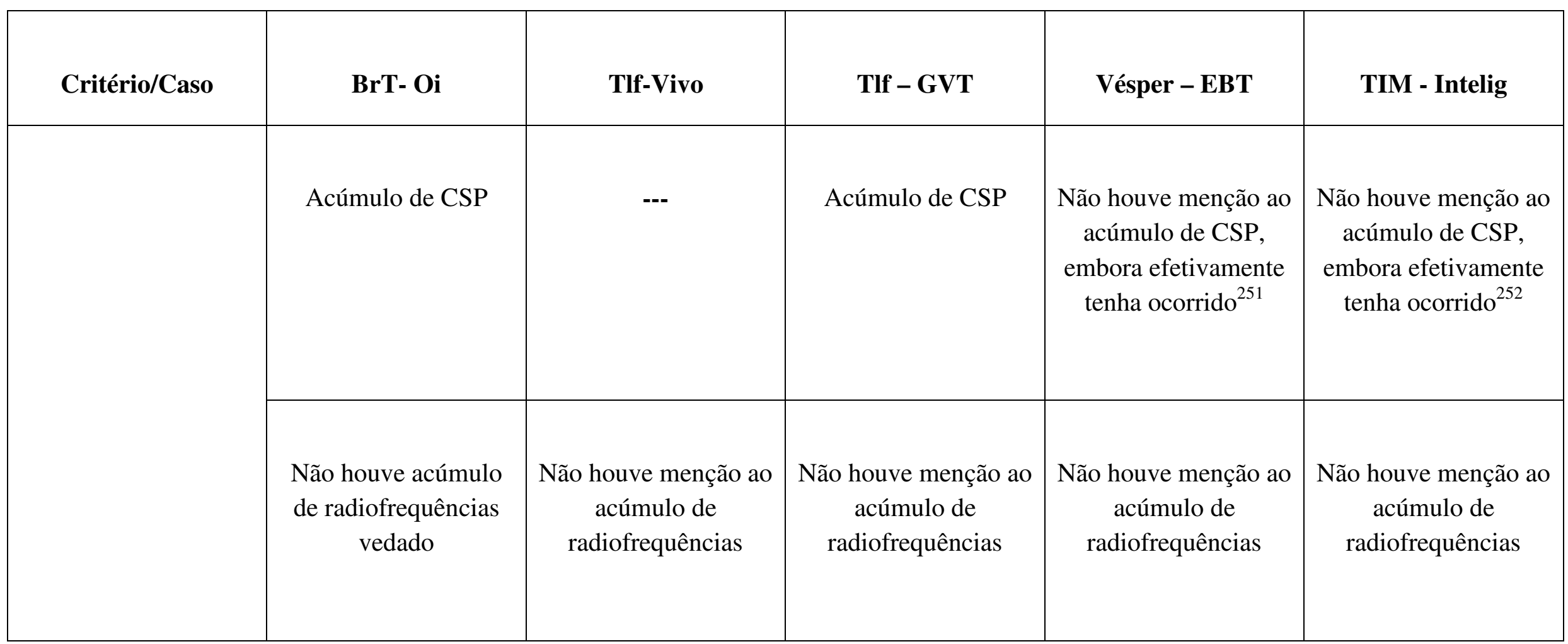

\footnotetext{
${ }^{251}$ Ocorreu o acúmulo dos CSPS 85 da Vésper S.A., 89 da Vésper São Paulo S.A. e 21 da Embratel

${ }^{252}$ Ocorreu o acúmulo dos CSPS 41 da TIM e 23 da Intelig.
} 


\begin{tabular}{|c|c|c|c|c|c|}
\hline Critério/Caso & BrT- Oi & Tlf-Vivo & Tlf - GVT & Vésper - EBT & TIM - Intelig \\
\hline & $\begin{array}{c}\text { I } \\
\text { Indícios de } \\
\text { participação cruzada } \\
\text { vedada por meio da } \\
\text { SERCOMTEL }\end{array}$ & $\begin{array}{c}\text { Indícios de } \\
\text { participação cruzada } \\
\text { ou controle vedado na } \\
\text { regulamentação } \\
\text { remediada pela } \\
\text { ANATEL } \\
\text { oportunamente }^{253}\end{array}$ & $\begin{array}{l}\text { Inexistência de } \\
\text { indícios de } \\
\text { participação cruzada } \\
\text { ou controle vedado na } \\
\text { regulamentação }\end{array}$ & $\begin{array}{c}\text { Inexistência de } \\
\text { indícios de } \\
\text { participação cruzada } \\
\text { ou controle vedado na } \\
\text { regulamentação }\end{array}$ & $\begin{array}{c}\text { Inexistência de } \\
\text { indícios de } \\
\text { participação cruzada } \\
\text { ou controle vedado na } \\
\text { regulamentação }\end{array}$ \\
\hline
\end{tabular}

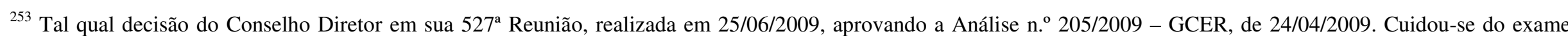
prévio da aquisição de participação acionária do Grupo Telefonica no Grupo Telecom Itáiia, em que a ANATEL determinou uma série de medidas acautelatórias destinadas a impedir o controle do Grupo Telefonica sobre o Grupo TIM no Brasil, vide Ato n. ${ }^{\circ}$ 68.276, de 31/10/2007 e 3.801, de 07/07/2009.
} 


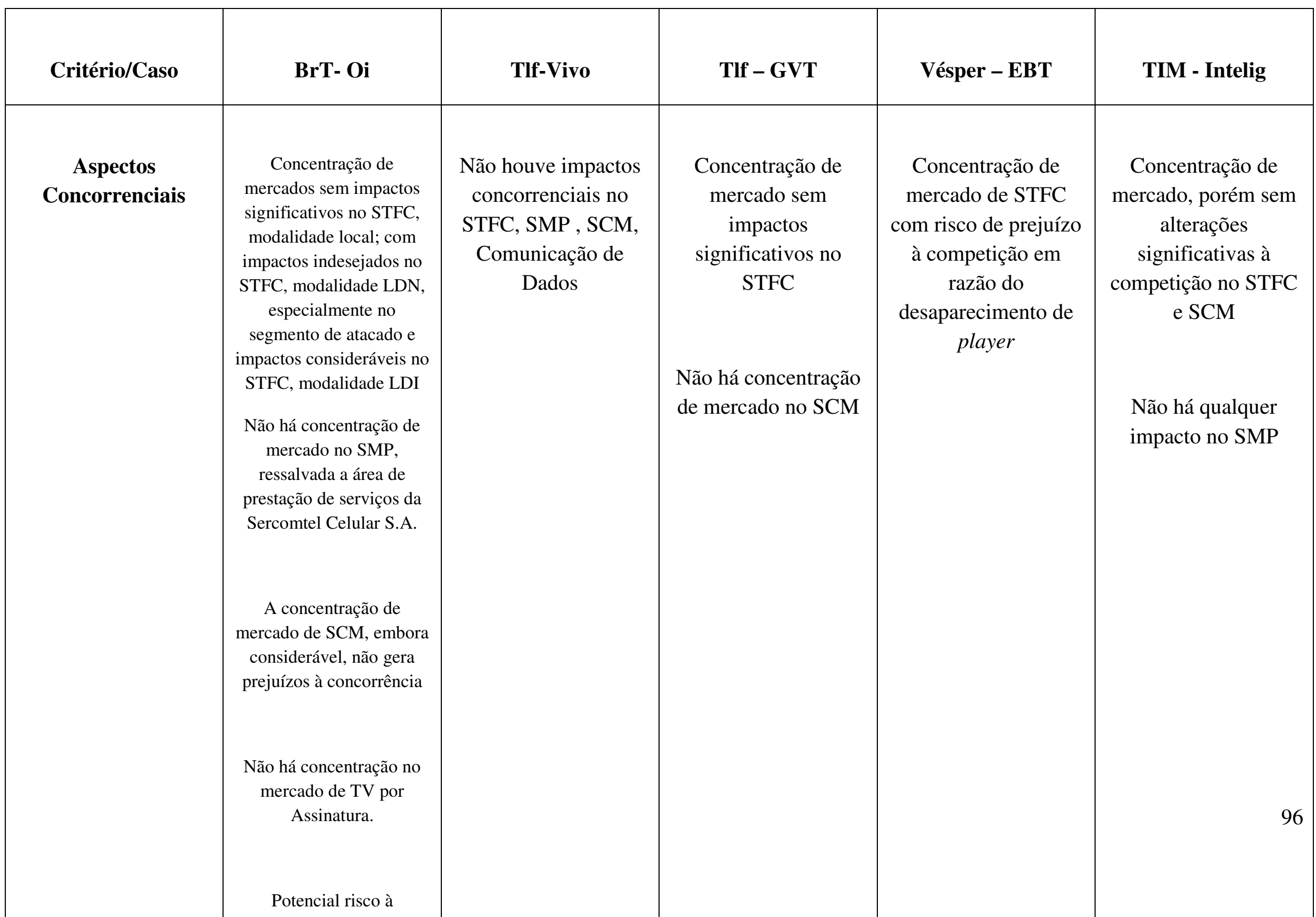




\begin{tabular}{|c|c|c|c|c|c|}
\hline Critério/Caso & BrT- Oi & Tlf-Vivo & Tlf - GVT & Vésper - EBT & TIM - Intelig \\
\hline $\begin{array}{l}\text { Benefícios aos } \\
\text { Usuários }\end{array}$ & $\begin{array}{c}\text { Não houve } \\
\text { demonstração de } \\
\text { benefício direto aos } \\
\text { usuários dos serviços } \\
\text { de telecomunicações } \\
\text { das operadoras } \\
\text { envolvidas na } \\
\text { operação }\end{array}$ & $\begin{array}{c}\text { Não houve } \\
\text { demonstração de } \\
\text { benefício direto aos } \\
\text { usuários dos serviços } \\
\text { de telecomunicações } \\
\text { das operadoras } \\
\text { envolvidas na } \\
\text { operação }\end{array}$ & $\begin{array}{c}\text { Não houve } \\
\text { demonstração de } \\
\text { benefício direto aos } \\
\text { usuários dos serviços } \\
\text { de telecomunicações } \\
\text { das operadoras } \\
\text { envolvidas na } \\
\text { operação }\end{array}$ & $\begin{array}{l}\text { Benefício direto dos } \\
500 \text { mil usuários da } \\
\text { Vésper S.A. e da } \\
\text { Vésper São Paulo } \\
\text { S.A. com a } \\
\text { continuidade da } \\
\text { prestação do STFC a } \\
\text { esses assinantes }\end{array}$ & $\begin{array}{c}\text { Não houve } \\
\text { demonstração de } \\
\text { benefício direto aos } \\
\text { usuários dos serviços } \\
\text { de telecomunicações } \\
\text { das operadoras } \\
\text { envolvidas na } \\
\text { operação }\end{array}$ \\
\hline $\begin{array}{l}\text { Externalidades } \\
\text { Positivas }\end{array}$ & $\begin{array}{c}\text { Sinergias } \\
\text { operacionais e } \\
\text { administrativas e } \\
\text { economia de escala }\end{array}$ & $\begin{array}{c}\text { Sinergias } \\
\text { operacionais e } \\
\text { administrativas e } \\
\text { economia de escala }\end{array}$ & $\begin{array}{c}\text { Sinergias } \\
\text { operacionais e } \\
\text { administrativas e } \\
\text { economia de escala }\end{array}$ & $\begin{array}{c}\text { Sinergias } \\
\text { operacionais e } \\
\text { administrativas e } \\
\text { economia de escala }\end{array}$ & $\begin{array}{c}\text { Sinergias } \\
\text { operacionais e } \\
\text { administrativas e } \\
\text { economia de escala }\end{array}$ \\
\hline
\end{tabular}




\begin{tabular}{|c|c|c|c|c|c|}
\hline Critério/Caso & BrT- Oi & Tlf-Vivo & Tlf - GVT & Vésper - EBT & TIM - Intelig \\
\hline Decisão & $\begin{array}{c}\text { Aprovação com } \\
\text { condicionamentos e } \\
\text { contrapartidas }\end{array}$ & $\begin{array}{c}\text { Aprovação com } \\
\text { condicionamentos e } \\
\text { contrapartidas }\end{array}$ & $\begin{array}{c}\text { Aprovação com } \\
\text { condicionamentos e } \\
\text { contrapartidas }\end{array}$ & $\begin{array}{c}\text { Aprovação com } \\
\text { condicionamento }\end{array}$ & $\begin{array}{c}\text { Aprovação com } \\
\text { condicionamento }\end{array}$ \\
\hline
\end{tabular}

Fonte: Elaboração própria. 
Com relação ao primeiro critério analisado, vedações legais e regulatórias, verificamos que, dentre os cinco casos analisados, dois apresentavam óbices legais e regulatórios à consecução da operação.

O caso BrT-Oi encontrava vedação regulatória no art. $8^{\circ}$ da Resolução n. ${ }^{\circ}$ 321/2002 (Plano Geral de Autorizações do Serviço Móvel Pessoal - PGA/SMP) ${ }^{254}$, haja vista que efetivada a operação as operadoras 14 Brasil Telecom Celular S.A. e Sercomtel Celular S.A. passariam à condição de empresas coligadas atuantes nas cidades de Londrina e Tamarana, concomitantemente. O caso Vésper-EBT, por sua vez, incidia na vedação legal constante do art. 68 da LGT $^{255}$, na medida em que com a concretização da operação se verificariam sobreposições de outorgas de STFC, prestados no regime público e no regime privado, simultaneamente.

Os demais casos: Tlf-Vivo, Tlf-GVT e TIM-Intelig, não apresentavam óbices legais e regulatórios que obstassem a realização das operações a priori.

Constatamos, em seguida, que em quatro precedentes existia sobreposição de outorgas.

O caso Brt-Oi apresentava sobreposição de outorgas de STFC, SMP e SCM. O caso Tlf-GVT proporcionava sobreposição de outorgas de STFC e SCM, tal como os casos Vésper-Embratel e TIM-Intelig.

O caso Tlf-Vivo não apresentava sobreposição de outorgas.

Averiguamos também que quatro dos casos analisados apresentavam acúmulo de CSP: Brt-Oi, Tlf-GVT, Vésper-EBT e TIM-Intelig; embora, nos dois últimos, não tenhamos identificado menção a este fato nas Análises, tampouco, manifestação da ANATEL a este respeito.

O caso Tlf-Vivo não apresentava acúmulo de CSP.

254 “Art. $8^{o}$. É vedada a uma mesma prestadora, sua controladora, controlada ou coligada, a prestação de SMP, SMC ou ambos por meio de mais de uma autorização ou concessão, em uma mesma área geográfica de prestação de serviço, ou parte dela."

255 "Art. 68. É vedada, a uma mesma pessoa jurídica, a exploração, de forma direta ou indireta, de uma mesma modalidade de serviço nos regimes público e privado, salvo em regiões, localidades ou áreas distintas." 
Aferimos, ainda, que o acúmulo de radiofrequências acontecia no caso Brt-Oi, porém, sem atingimento dos limites máximos fixados na regulamentação. ${ }^{256}$

Nos demais casos não houve menção ao acúmulo de radiofrequências.

Verificamos, ademais, que dois precedentes apresentavam indícios de participação cruzada ou controle vedado na regulamentação.

O caso Brt-Oi demonstrava participação cruzada vedada por meio da Sercomtel S.A., concessionária de STFC e autorizatária de SMP. O caso Tlf-Vivo apresentava indícios de controle vedado pelo Grupo Telefonica de operadoras integrantes do Grupo TIM.

Os demais precedentes não apresentavam indícios de participação cruzada ou controle vedado na regulamentação setorial.

Constatamos, por fim, com relação ao primeiro critério examinado, que apenas no caso Vésper-EBT existia potencial risco de descumprimento das obrigações contratuais assumidas pelas operadoras. Esta situação decorria dos problemas financeiros da Vésper S.A. e Vésper São Paulo S.A.

Nos demais precedentes não se constatou risco de descumprimento das obrigações assumidas por meio dos contratos de concessão de STFC e dos termos de autorização de SMP e SCM.

Quanto ao segundo critério estudado, aspectos concorrenciais, apuramos que em quatro precedentes ocorreria concentração de mercado em todos ou alguns serviços de telecomunicações com impactos variados.

O caso Brt-Oi apresentava concentração de mercado, sem impacto significativo no STFC, modalidade Local; com impactos indesejados no STFC, modalidade LDN, segmento de atacado; e com impactos consideráveis no STFC, modalidade LDI. Não se verificava, ainda, concentração de mercado no SMP, uma vez que as operadoras móveis dos grupos econômicos atuavam em áreas distintas, salvo na área de prestação de serviços da Sercomtel Celular S.A. Da mesma forma, não se apurava concentração de mercado de TV por Assinatura, considerando que a BrT não atuava nesse mercado. Constatou-se,

${ }^{256}$ Vide Resolução n. ${ }^{\text {4 454/2006. }}$ 
ainda, que a concentração de mercado, embora existente também no mercado de SCM, não propiciaria prejuízos à concorrência, haja vista a grande quantidade de players atuantes nesse mercado e a sua alta competitividade. Não se vislumbrou, também, prejuízos à concorrência nos serviços de conexão em redes de fibra ótica; mas sim, potencial risco à competição nos serviços baseados em Internet.

O caso Tlf-GVT, também, apresentava concentração de mercado, sem impactos significativos no STFC; e inexistência de concentração de mercado no SCM.

O caso Vésper-EBT evidenciava, ainda, concentração de mercado de STFC, com risco efetivo de prejuízo à competição, em razão do desaparecimento precoce de duas das empresas-espelho do modelo de desestatização setorial.

O caso TIM-Intelig apontava, por fim, para concentração de mercado, porém, sem impactos significativos no STFC e SMP, inexistindo impactos no SMP.

Não se constatava concentração de mercado e impactos à concorrência no precedente Tlf-Vivo, tendo em vista que a operação, nesse caso, limitava-se à consolidação do controle do Grupo Telefonica na Vivo.

Com relação ao terceiro critério, benefícios aos usuários, verificamos que apenas no caso Vésper-EBT os usuários seriam diretamente beneficiados pela operação, na medida em que os serviços prestados pela Vésper S.A. e pela Vésper São Paulo não seriam descontinuados. ${ }^{257}$

Quanto ao quarto critério, externalidades positivas da operação, apuramos que em todos os casos foi apontada a existência de possíveis sinergias operacionais e administrativas e economias de escala que beneficiariam as operadoras envolvidas na operação.

Por fim, constatamos que a ANATEL aprovou as operações em todos os precedentes estudados. Em dois casos, a Agência Reguladora impôs apenas condicionamentos, Vésper-EBT e TIM-Intelig. Nos outros três, determinou, além dos condicionamentos, contrapartidas: casos Brt-Oi, Tlf-Vivo e Tlf-GVT.

\footnotetext{
${ }^{257}$ Havia, ainda, em outros precedentes, menção genérica a eventual benefício aos usuários decorrentes do ocasional repasse de economia de escala das operadoras envolvidas na operação a esses. Contudo, considerando a eventualidade, generalidade e a indeterminabilidade, esses benefícios não foram considerados em nossa avaliação.
} 
Os exatos termos das aprovações concedidas pela ANATEL nos precedentes analisados serão examinados no item a seguir.

III. II. 4. 2. Os Condicionamentos e Contrapartidas Impostos pela ANATEL.

Os condicionamentos impostos pela ANATEL nos precedentes estudados foram os seguintes. 


\section{TABELA 2}

Condicionamentos Impostos pela ANATEL

\begin{tabular}{|c|c|c|c|c|c|}
\hline Critério/Caso & Brt-Oi & Tlf-Vivo & Tlf-GVT & Vésper-EBT & TIM-Intelig \\
\hline & $\begin{array}{c}\text { Regularizar } \\
\text { sobreposições de } \\
\text { outorgas em } 18 \\
\text { meses }\end{array}$ & --- & $\begin{array}{c}\text { Regularizar } \\
\text { sobreposições de } \\
\text { outorgas em } 18 \\
\text { meses }\end{array}$ & $\begin{array}{c}\text { Regularizar } \\
\text { sobreposições de } \\
\text { outorgas em } 18 \\
\text { meses }\end{array}$ & $\begin{array}{c}\text { Regularizar } \\
\text { sobreposições de } \\
\text { outorgas em } 18 \\
\text { meses }\end{array}$ \\
\hline & Devolução de CSP & --- & Devolução de CSP & -- & -- \\
\hline
\end{tabular}




\begin{tabular}{|c|c|c|c|c|c|}
\hline Condicionamentos & --- & -- & $\begin{array}{l}\text { Manter autônomas } \\
\text { e independentes as } \\
\text { estruturas } \\
\text { administrativas, } \\
\text { operacionais, } \\
\text { funcionais e } \\
\text { comerciais das } \\
\text { operadoras }\end{array}$ & -- & --- \\
\hline Critério/Caso & Brt-Oi & TIf-Vivo & TIf-GVT & Vésper-EBT & TIM-Intelig \\
\hline Condicionamentos & --- & -- & $\begin{array}{l}\text { Operar de forma } \\
\text { separada contábil e } \\
\text { financeiramente }\end{array}$ & -- & -- \\
\hline
\end{tabular}




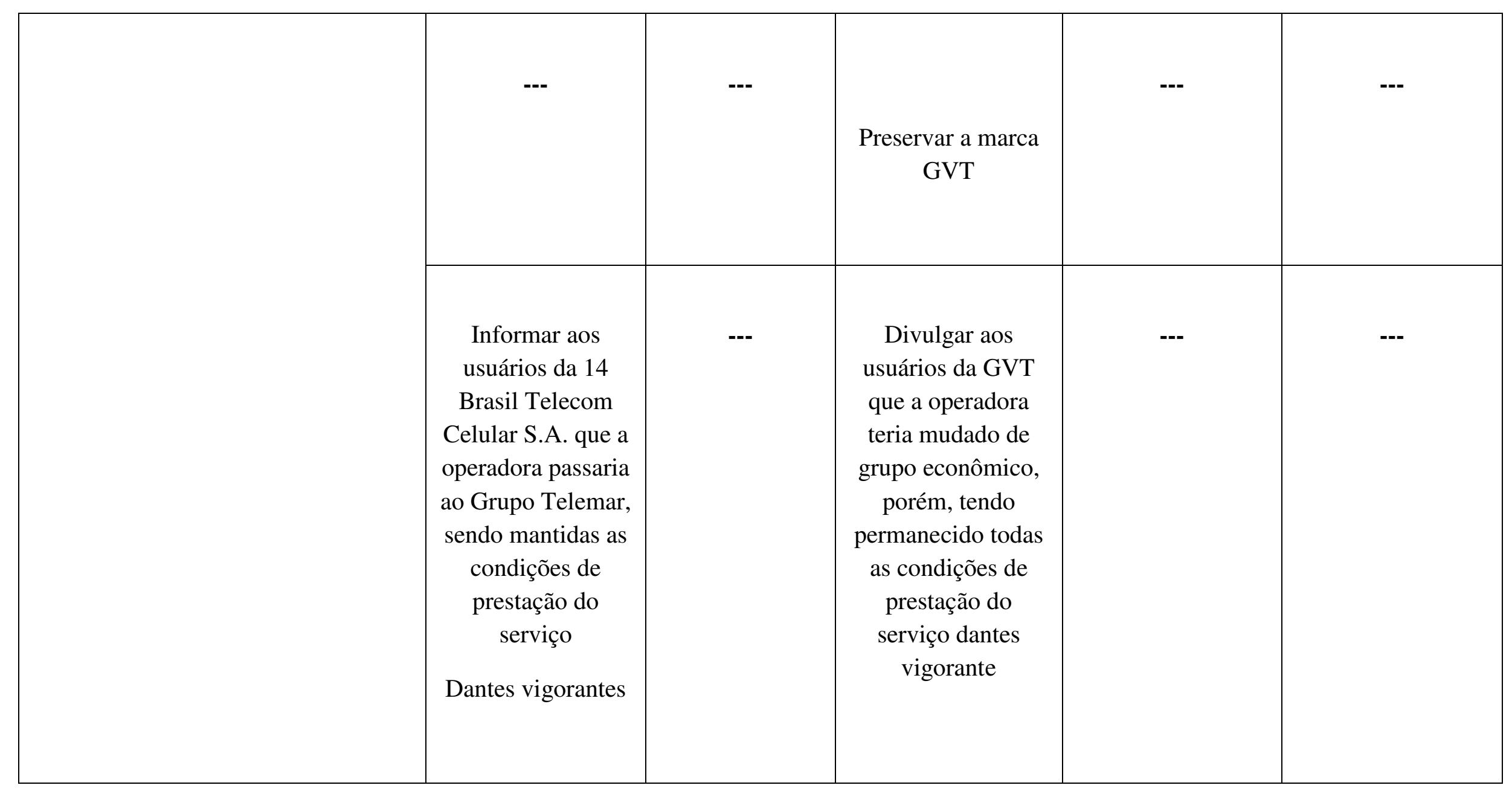




\begin{tabular}{|c|c|c|c|c|c|}
\hline Critério/Caso & Brt-Oi & Tlf-Vivo & TIf-GVT & Vésper-EBT & TIM-Intelig \\
\hline \multirow{2}{*}{ Condicionamentos } & $\begin{array}{l}\text { Comunicados à } \\
\text { ANATEL de } \\
\text { ordem societária } \\
\text { após a } \\
\text { concretização da } \\
\text { operação }\end{array}$ & --- & $\begin{array}{c}\text { Comunicados à } \\
\text { ANATEL de ordem } \\
\text { societária e } \\
\text { econômico- } \\
\text { financeira após a } \\
\text { concretização da } \\
\text { operação }\end{array}$ & --- & --- \\
\hline & --- & --- & $\begin{array}{l}\text { Informar plano de } \\
\text { investimentos e } \\
\text { evolução da } \\
\text { expansão da oferta } \\
\text { de serviços após a } \\
\text { concretização da } \\
\text { operação }\end{array}$ & --- & --- \\
\hline
\end{tabular}


Fonte: Elaboração própria. 
Averiguamos que em todas as operações em que se constatavam sobreposição de outorgas, a ANATEL concedeu o prazo de 18 meses para que as operadoras envolvidas nas operações regularizassem essa situação. ${ }^{258}$

Não houve, portanto, esta determinação no caso Tlf-Vivo, uma vez que não existiam sobreposições de outorgas de serviços de telecomunicações entre as operadoras envolvidas na operação.

Constatamos que nos casos Brt-Oi e Tlf-GVT a ANATEL concedeu, ainda, o mesmo prazo para a devolução à Agência Reguladora dos CSPs excedentes. Notamos a este respeito que nos casos Vésper-EBT e TIM-Intelig, embora também tenha ocorrido o acúmulo de CSPs, a ANATEL não condicionou a aprovação dessas operações a devolução de seu excedente.

No precedente Tlf-Vivo não houve acúmulo de CSP.

Três condicionamentos foram impostos exclusivamente no caso Tlf-GVT: a manutenção autônoma e independente das estruturas administrativas, operacionais, funcionais e comerciais das operadoras envolvidas na operação, bem como sua operação contábil e financeira de maneira individualizada e a preservação da marca GVT.

Estes condicionamentos não foram impostos nos demais precedentes.

Os casos Oi-Brt e Tlf-GVT apresentam, ainda, dois outros condicionamentos similares: o dever de informar aos usuários das operadoras a mudança de seu grupo econômico e assegurar-lhes a manutenção das condições contratadas do serviço de telecomunicações, assim como o dever de comunicar à ANATEL as alterações de ordem societária e, quando aplicável, econômico-financeira decorrentes da concretização das operações aprovadas.

Os demais precedentes não contaram com estes condicionamentos.

O caso Tlf-GVT condicionou-se, por fim, ao dever do Grupo Telefonica informar à ANATEL o plano de investimentos e evolução da expansão da oferta de serviços na área de operação da GVT.

${ }^{258}$ Essa determinação da ANATEL, como vimos oportunamente, originou-se no caso Vésper-EBT e aplicouse, a partir daí, continuamente, às situações de sobreposição de outorgas; culminando com a própria positivação da regra cultivada casuisticamente pela Agência Reguladora. Frise-se que essa é também a premissa da LGT. 
Este condicionamento não encontrou similar nos outros precedentes.

Além dos condicionamentos apresentados acima, em alguns precedentes foram impostas contrapartidas à aprovação das operações. Vejamos. 


\section{TABELA 3}

Contrapartidas Impostas pela ANATEL

\begin{tabular}{|c|c|c|c|c|c|}
\hline Critério/Caso & BrT-Oi & Tlf-Vivo & Tlf-GVT & Vésper-EBT & TIM-Intelig \\
\hline Contrapartidas & $\begin{array}{c}\text { Aumentar o número } \\
\text { de sedes municipais } \\
\text { interligadas com fibra } \\
\text { ótica nas Regiões I e } \\
\text { II do PGO }\end{array}$ & --- & $-\cdots$ & $-\cdots$ \\
\hline
\end{tabular}




\begin{tabular}{|c|c|c|c|c|c|}
\hline Critério/Caso & BrT-Oi & TIf-Vivo & TIf-GVT & Vésper-EBT & TIM-Intelig \\
\hline & $\begin{array}{c}\text { Ofertar provimento } \\
\text { de acesso à Internet } \\
\text { em banda larga em } \\
\text { todas as sedes dos } \\
\text { municípios das } \\
\text { Regiões I II do PGO } \\
\text { com velocidade de } \\
150 \text { kbps a preços } \\
\text { isonômicos no piso }\end{array}$ & -- & --- & $\cdots$ \\
\hline
\end{tabular}




\begin{tabular}{|c|c|c|c|c|c|}
\hline Critério/Caso & BrT-Oi & Tlf-Vivo & Tlf-GVT & Vésper-EBT & TIM-Intelig \\
\hline & $\begin{array}{c}\text { Implantar e } \\
\text { disponibilizar o } \\
\text { acesso comutado à } \\
\text { Internet, no âmbito do } \\
\text { STFC, modalidade } \\
\text { local, em 56\% dos } \\
\text { municípios da Região } \\
\text { I do PGO ou, quando } \\
\text { tais municípios não } \\
\text { sejam alcançáveis, } \\
\text { disponibilizar uma } \\
\text { alternativa de acesso } \\
\text { discado à Internet }\end{array}$ & --- & --- & --- & -- \\
\hline & Neutralidade de rede & --- & Neutralidade de rede & --- & -- \\
\hline
\end{tabular}




\begin{tabular}{|c|c|c|c|c|c|}
\hline Critério/Caso & BrT-Oi & TIf-Vivo & TIf-GVT & Vésper-EBT & TIM-Intelig \\
\hline & $\begin{array}{c}\text { Adquirir e } \\
\text { comercializar cartões } \\
\text { indutivos } \\
\text { exclusivamente que } \\
\text { contenham } \\
\text { informação quanto ao } \\
\text { valor resultante da } \\
\text { tarifa homologada } \\
\text { pela ANATEL, com } \\
\text { impostos }\end{array}$ & --- & $\cdots$ & $\cdots$ \\
\hline
\end{tabular}




\begin{tabular}{|c|c|c|c|c|c|}
\hline Critério/Caso & BrT-Oi & TIf-Vivo & TIf-GVT & Vésper-EBT & TIM-Intelig \\
\hline & $\begin{array}{c}\text { Fornecer a } \\
\text { instituições públicas, } \\
\text { prioritariamente do } \\
\text { sistema público de } \\
\text { saúde, dois mil } \\
\text { conjuntos compostos } \\
\text { por antena, } \\
\text { decodificador e } \\
\text { televisor }\end{array}$ & $\cdots$ & --- & $\cdots$ \\
\hline
\end{tabular}




\begin{tabular}{|c|c|c|c|c|c|}
\hline Critério/Caso & BrT-Oi & TIf-Vivo & TIf-GVT & Vésper-EBT & TIM-Intelig \\
\hline & $\begin{array}{c}\text { Incluir em sua grade } \\
\text { básica de DTH e TV } \\
\text { a Cabo um canal de } \\
\text { conteúdo nacional de } \\
\text { produção } \\
\text { independente. }\end{array}$ & -- & -- & - & -- \\
\hline & $\begin{array}{c}\text { Disponibilizar ofertas } \\
\text { voltadas à } \\
\text { popularização do } \\
\text { Serviço de TV por } \\
\text { Assinatura }\end{array}$ & --- & $\cdots$ & --- & --- \\
\hline
\end{tabular}




\begin{tabular}{|c|c|c|c|c|c|}
\hline Critério/Caso & BrT-Oi & Tlf-Vivo & Tlf-GVT & Vésper-EBT & TIM-Intelig \\
\hline & $\begin{array}{l}\text { Oferecer na Região } \\
\text { II, nas mesmas } \\
\text { condições, os } \\
\text { produtos e serviços } \\
\text { disponíveis na Região } \\
\text { I do PGO }\end{array}$ & -- & -- & -- & -- \\
\hline & $\begin{array}{c}\text { Desenvolver ações } \\
\text { para a preservação do } \\
\text { meio ambiente }\end{array}$ & -- & -- & --- & -- \\
\hline
\end{tabular}




\begin{tabular}{|c|c|c|c|c|c|}
\hline Critério/Caso & BrT-Oi & Tlf-Vivo & TIf-GVT & Vésper-EBT & TIM-Intelig \\
\hline & $\begin{array}{l}\text { Instalar postos de } \\
\text { recolhimento de } \\
\text { baterias e aparelhos } \\
\text { celular usados }\end{array}$ & --- & -- & -- & -- \\
\hline & $\begin{array}{c}\text { Desenvolver } \\
\text { programa de } \\
\text { distribuição gratuita } \\
\text { para reutilização dos } \\
\text { aparelhos usados }\end{array}$ & -- & -- & -- & -- \\
\hline
\end{tabular}




\begin{tabular}{|c|c|c|c|c|c|}
\hline Critério/Caso & BrT-Oi & Tlf-Vivo & TIf-GVT & Vésper-EBT & TIM-Intelig \\
\hline & --- & $\begin{array}{l}\text { Ativar a rede e prestar } \\
\text { SMP em } 35 \\
\text { municípios sem esse } \\
\text { serviço no } \\
\text { cronograma indicado } \\
\text { pela ANATEL }\end{array}$ & -- & -- & -- \\
\hline & --- & $\begin{array}{l}\text { Promover a cobertura } \\
3 \mathrm{G} \text { do SMP em } 83 \\
\text { municípios além } \\
\text { daqueles já acordados } \\
\text { com a ANATEL }\end{array}$ & -- & --- & --- \\
\hline
\end{tabular}




\begin{tabular}{|c|c|c|c|c|c|}
\hline Critério/Caso & BrT-Oi & Tlf-Vivo & TIf-GVT & Vésper-EBT & TIM-Intelig \\
\hline & $\begin{array}{c}\text { Disponibilizar, nos } \\
\text { pontos de presença } \\
\text { das organizações } \\
\text { militares da fronteira } \\
\text { do Ministério da } \\
\text { Defesa, um sistema } \\
\text { de comunicação de } \\
\text { voz e dados }\end{array}$ & -- & -- & -- & -- \\
\hline & $\begin{array}{l}\text { Fornecer acesso de } \\
\text { 1Mbps de banda e } \\
\text { equipamentos } \\
\text { correspondentes para } \\
\text { fruição do serviço }\end{array}$ & -- & -- & -- & -- \\
\hline
\end{tabular}




\begin{tabular}{|c|c|c|c|c|c|}
\hline Critério/Caso & BrT-Oi & TIf-Vivo & TIf-GVT & Vésper-EBT & TIM-Intelig \\
\hline & $\begin{array}{l}\text { Treinar técnicos em } \\
\text { sistemas de } \\
\text { comunicação no } \\
\text { Exército Brasileiro }\end{array}$ & -- & - & --- & --- \\
\hline & $\begin{array}{c}\text { Apresentar } \\
\text { Memorando de } \\
\text { Entendimentos } \\
\text { referente ao Projeto } \\
\text { Sistema } \\
\text { Geoestacionário } \\
\text { Brasileiro }\end{array}$ & -- & -- & --- & --- \\
\hline
\end{tabular}




\begin{tabular}{|c|c|c|c|c|c|}
\hline Critério/Caso & BrT-Oi & Tlf-Vivo & Tlf-GVT & Vésper-EBT & TIM-Intelig \\
\hline & $\begin{array}{l}\text { Investir em pesquisa e } \\
\text { desenvolvimento } \\
100 \% \text { dos valores } \\
\text { recolhidos ao } \\
\text { FUNTTEL }\end{array}$ & --- & $\begin{array}{l}\text { Investir em pesquisa e } \\
\text { desenvolvimento } \\
100 \% \text { dos valores } \\
\text { recolhidos ao } \\
\text { FUNTTEL }\end{array}$ & --- & --- \\
\hline & $\begin{array}{l}\text { Ceder capacidade de } \\
\text { transmissão em fibras } \\
\text { óticas para uso não } \\
\text { comercial pela Rede } \\
\text { Nacional de } \\
\text { Pesquisas (RNP) }\end{array}$ & $\begin{array}{l}\text { Ceder capacidade de } \\
\text { transmissão em fibras } \\
\text { óticas para uso não } \\
\text { comercial pela Rede } \\
\text { Nacional de } \\
\text { Pesquisas (RNP) }\end{array}$ & --- & --- & --- \\
\hline
\end{tabular}




\begin{tabular}{|c|c|c|c|c|c|}
\hline Critério/Caso & BrT-Oi & Tlf-Vivo & TIf-GVT & Vésper-EBT & TIM-Intelig \\
\hline & $\begin{array}{c}\text { Estabelecer nas } \\
\text { aquisições de } \\
\text { equipamentos e } \\
\text { sistemas de elevado } \\
\text { valor monetário ou de } \\
\text { importância } \\
\text { estratégica, padrões } \\
\text { ou índices de } \\
\text { nacionalização para } \\
\text { aquisição no mercado } \\
\text { local }\end{array}$ & --- & $\begin{array}{c}\text { Estabelecer nas } \\
\text { aquisições de } \\
\text { equipamentos e } \\
\text { sistemas de elevado } \\
\text { valor monetário ou de } \\
\text { importância } \\
\text { estratégica, padrões } \\
\text { ou índices de } \\
\text { nacionalização para } \\
\text { aquisição no mercado } \\
\text { local }\end{array}$ & --- & --- \\
\hline & $\begin{array}{c}\text { Informar sobre a } \\
\text { atuação internacional } \\
\text { do grupo }\end{array}$ & --- & --- & --- & --- \\
\hline
\end{tabular}




\begin{tabular}{|c|c|c|c|c|c|}
\hline Critério/Caso & BrT-Oi & Tlf-Vivo & TIf-GVT & Vésper-EBT & TIM-Intelig \\
\hline & $\begin{array}{l}\text { Criar uma gerência } \\
\text { comercial e agilizar o } \\
\text { atendimento de outros } \\
\text { prestadores de } \\
\text { serviços de } \\
\text { telecomunicações de } \\
\text { interesse coletivo }\end{array}$ & --- & --- & -- & --- \\
\hline & $\begin{array}{l}\text { Manter ou reduzir o } \\
\text { percentual de } \\
\text { atendimento de EILD } \\
\text { especial }\end{array}$ & -- & $\begin{array}{l}\text { Manter ou reduzir o } \\
\text { percentual de } \\
\text { atendimento de EILD } \\
\text { especial }\end{array}$ & -- & --- \\
\hline
\end{tabular}




\begin{tabular}{|c|c|c|c|c|c|}
\hline Critério/Caso & BrT-Oi & Tlf-Vivo & Tlf-GVT & Vésper-EBT & TIM-Intelig \\
\hline & $\begin{array}{l}\text { Ofertar EILD especial } \\
\text { na Região I do PGO } \\
\text { em montante igual ou } \\
\text { inferior ao da BrT na } \\
\text { Região II }\end{array}$ & -- & -- & -- & --- \\
\hline & $\begin{array}{l}\text { Prestar informações } \\
\text { sobre EILD à } \\
\text { ANATEL }\end{array}$ & -- & $\begin{array}{l}\text { Prestar informações } \\
\text { sobre EILD à } \\
\text { ANATEL }\end{array}$ & -- & --- \\
\hline
\end{tabular}




\begin{tabular}{|c|c|c|c|c|c|}
\hline Critério/Caso & BrT-Oi & Tlf-Vivo & Tlf-GVT & Vésper-EBT & TIM-Intelig \\
\hline & $\begin{array}{l}\text { Adotar sistemas de } \\
\text { divulgação e } \\
\text { publicidade na } \\
\text { Internet sobre suas } \\
\text { ofertas de atacado } \\
\text { (EILD, backhaul, } \\
\text { recursos de redes, } \\
\text { transporte, comutação } \\
\text { e trânsito, } \\
\text { fornecimento de } \\
\text { cadastro, co- } \\
\text { faturamento e uso de } \\
\text { plataforma de pré- } \\
\text { pagamento) }\end{array}$ & -- & $\begin{array}{c}\text { Adotar sistemas de } \\
\text { divulgação e } \\
\text { publicidade na } \\
\text { Internet sobre suas } \\
\text { ofertas de atacado } \\
\text { (EILD, backhaul, } \\
\text { recursos de redes, } \\
\text { transporte, comutação } \\
\text { e trânsito, } \\
\text { fornecimento de } \\
\text { cadastro, co- } \\
\text { faturamento e uso de } \\
\text { plataforma de pré- } \\
\text { pagamento) }\end{array}$ & -- & --- \\
\hline
\end{tabular}




\begin{tabular}{|c|c|c|c|c|c|}
\hline Critério/Caso & BrT-Oi & Tlf-Vivo & TIf-GVT & Vésper-EBT & TIM-Intelig \\
\hline & $\begin{array}{l}\text { Desenvolver e tornar } \\
\text { operacional, nas } \\
\text { Regiões I e II do } \\
\text { PGO, sistema que } \\
\text { permita o envio de } \\
\text { informações à } \\
\text { ANATEL referente } \\
\text { aos planos de serviço, } \\
\text { promoções, vantagens } \\
\text { e descontos ofertados } \\
\text { na exploração dos } \\
\text { serviços de } \\
\text { telecomunicações, em } \\
\text { periodicidade diária }\end{array}$ & -- & $\begin{array}{l}\text { Desenvolver e operar, } \\
\text { na Região III do } \\
\text { PGO, sistema para o } \\
\text { envio de informações } \\
\text { à ANATEL relativas } \\
\text { aos planos de serviço, } \\
\text { promoções, vantagens } \\
\text { e descontos em } \\
\text { serviços de } \\
\text { telecomunicações, em } \\
\text { periodicidade diária }\end{array}$ & -- & -- \\
\hline
\end{tabular}




\begin{tabular}{|c|c|c|c|c|c|}
\hline Critério/Caso & BrT-Oi & Tlf-Vivo & Tlf-GVT & Vésper-EBT & TIM-Intelig \\
\hline & $\begin{array}{l}\text { Desenvolver sistema } \\
\text { de controle de fila e } \\
\text { de sequencia de } \\
\text { atendimento a } \\
\text { pedidos de ofertas de } \\
\text { atacado }\end{array}$ & --- & $\begin{array}{l}\text { Desenvolver sistema } \\
\text { de controle de fila e } \\
\text { sequência de } \\
\text { atendimento a } \\
\text { pedidos de ofertas de } \\
\text { atacado }\end{array}$ & --- & --- \\
\hline & $\begin{array}{l}\text { Dispensar tratamento } \\
\text { isonômico e não } \\
\text { discriminatório a } \\
\text { todas as prestadoras } \\
\text { de serviços de } \\
\text { telecomunicações de } \\
\text { interesse coletivo na } \\
\text { oferta de EILD }\end{array}$ & -- & --- & --- & --- \\
\hline
\end{tabular}




\begin{tabular}{|c|c|c|c|c|c|}
\hline Critério/Caso & BrT-Oi & Tlf-Vivo & Tlf-GVT & Vésper-EBT & TIM-Intelig \\
\hline & $\begin{array}{l}\text { Manter os postos de } \\
\text { trabalho na empresa e } \\
\text { suas controladas até } \\
\text { abril de } 2011\end{array}$ & -- & $\begin{array}{l}\text { Manter o nível de } \\
\text { emprego }\end{array}$ & --- & --- \\
\hline & $\begin{array}{l}\text { Renunciar aos } \\
\text { direitos discutidos na } \\
\text { ação judicial n. } \\
\text { 2003.34.00.006713-0 }\end{array}$ & -- & -- & -- & -- \\
\hline
\end{tabular}




\begin{tabular}{|c|c|c|c|c|c|}
\hline Critério/Caso & BrT-Oi & Tlf-Vivo & Tlf-GVT & Vésper-EBT & TIM-Intelig \\
\hline & $\begin{array}{l}\text { Coordenar com a } \\
\text { ANATEL ações com } \\
\text { vistas à resolução de } \\
\text { PADOS referentes à } \\
\text { universalização e } \\
\text { qualidade dos } \\
\text { serviços }\end{array}$ & --- & -- & --- & -- \\
\hline
\end{tabular}

Fonte: Elaboração própria. 
Aferimos, assim, que nos precedentes Oi-Brt, Tlf-Vivo e Tlf-GVT foram impostas contrapartidas à aprovação das operações submetidas à ANATEL.

Nos casos Vésper-EBT e TIM-Intelig não foram impostas quaisquer contrapartidas.

Verificamos, também, que o precedente Oi-BrT contou com a imposição de maior quantidade de contrapartidas pela ANATEL, razão pela qual, para nossa análise comparativa, o tomamos como referência.

As contrapartidas determinadas no caso Oi-Brt foram agrupadas em treze grupos distintos, os quais indicamos abaixo, seguidos da síntese das compensações impostas pela ANATEL e da análise comparativa com os demais precedentes estudados.

A primeira ordem de contrapartidas, nesse caso, correspondeu à modernização e à expansão da rede de fibras óticas nacional, com o compromisso de a Oi-BrT aumentar o número de sedes municipais interligadas com fibras óticas nas Regiões I e II, do PGO, nos prazos fixados pela ANATEL.

Este grupo de contrapartidas não encontrou correspondentes nos demais casos analisados.

A segunda ordem de contrapartidas referiu-se à expansão da oferta comercial de banda larga e a terceira ao estímulo ao uso do acesso comutado à Internet, com as obrigações de a Oi-BrT ofertar provimento de acesso à Internet em banda larga em todas as sedes dos municípios das Regiões I e II do PGO, com velocidade de $150 \mathrm{kbps}$ e implantar e disponibilizar o acesso comutado à Internet em 56\% dos municípios da Região I do PGO ou, quando tais municípios não sejam alcançáveis, disponibilizar uma alternativa ao acesso discado.

A segunda e a terceira ordem de contrapartidas não foram verificadas nos outros precedentes.

A quarta ordem de contrapartidas disse respeito aos serviços baseados na Internet, na qual se determinou à Brt-Oi a adoção da neutralidade de redes.

A contrapartida da adoção da neutralidade de rede pelas operadoras também foi constatada no precedente Tlf-GVT; porém, não foi verificada nos demais precedentes. 
A quinta ordem de contrapartidas aludiu à comercialização de cartões indutivos com informação tarifária homologada pela ANATEL e não foi encontrada nos outros precedentes examinados.

A sexta ordem de contrapartidas tratou da TV por Assinatura e obrigou à BrTOi a fornecer a instituições públicas, prioritariamente do sistema público de saúde, dois mil conjuntos compostos por antena, decodificador e televisor; incluir em sua grade básica de DTH e TV a Cabo um canal de conteúdo nacional de produção independente e disponibilizar ofertas voltadas á popularização do Serviço de TV por Assinatura.

Não constatamos contrapartidas desta ordem nos outros precedentes estudados.

A sétima ordem de contrapartidas abordou à prestação do SMP e impôs à BrTOi o dever de oferecer na Região II do PGO, nas mesmas condições, os produtos e serviços disponibilizados na Região I do PGO, bem como desenvolver ações para a preservação do meio ambiente, instalação de postos de recolhimento de baterias e aparelhos celulares usados e reutilização destes últimos.

Este grupo de contrapartidas não se apresentou nos outros precedentes.

O precedente Tlf-Vivo contou, também, com contrapartidas relativas à prestação do SMP, porém, sem correspondência com as contrapartidas do caso BrT-Oi, quais sejam, ativar a rede e prestar SMP em 35 municípios sem o serviço de acordo com o cronograma indicado pela ANATEL e promover a cobertura 3G do SMP em 83 municípios além daqueles já acordados com a ANATEL.

Estas contrapartidas impostas no caso Tlf-Vivo não foram encontradas nos demais precedentes e não apresentou correspondente no caso Brt-Oi.

A oitava ordem de contrapartidas correspondeu ao emprego de telecomunicações para fins de segurança nacional e determinou à Brt-Oi a disponibilização, nos pontos de presença das organizações militares da fronteira do Ministério da Defesa, um sistema de comunicação de voz e dados, o fornecimento de acesso de $1 \mathrm{Mbps}$ de banda e equipamentos correspondentes para fruição do serviço, além do treinamento de técnicos em sistemas de comunicação no exército brasileiro e apresentação de memorando de entendimentos referente ao Projeto Sistema Geoestacionário Brasileiro. 
Não se verificou nos outros precedentes compensações como estas.

A nona ordem de contrapartidas correspondeu aos investimentos em pesquisa e desenvolvimento, com a imposição de três obrigações principais à Brt-Oi: a realização de investimentos em valores anuais correspondentes a até $100 \%$ do total recolhido ao Fundo para o Desenvolvimento Tecnológico das Telecomunicações (FUNTTEL), respeitado o compromisso mínimo de 50\% do total incondicionalmente; o dever de ceder capacidade de transmissão em fibras óticas, para uso não comercial, pela Rede Nacional de Pesquisas (RNP), que viabilize a interconexão nacional entre universidades e seus campi, centros de pesquisa, laboratórios, hospitais de ensino e museus; e a obrigação de estabelecer, nas aquisições de equipamentos e sistemas de elevado valor monetário ou de importância estratégica, padrões ou índices de nacionalização para aquisição no médio e longo prazo no mercado local, promovendo iniciativas de fabricação local, observadas as diretrizes do Processo Produtivo Básico (PPB) do Governo Federal.

A compensação relativa ao investimento de valores do FUNTTEL em pesquisa e desenvolvimento e, bem assim, de estímulo ao mercado de equipamentos e sistemas nacionais também se verificou no caso Tlf-GVT, mas não nos demais.

A contrapartida atinente à cessão de capacidade à RNP da mesma forma foi imposta no caso Tlf-Vivo, porém não nos demais precedentes.

A décima ordem de contrapartidas referiu-se ao acompanhamento do movimento de internacionalização da Brt-Oi e obrigou a nova operadora a informar à Anatel sobre sua atuação internacional trimestralmente.

Esta contrapartida não foi constatada nos outros casos analisados.

A décima primeira ordem de contrapartidas abordou a competição e o relacionamento com outras prestadoras de serviços de telecomunicações de interesse coletivo e obrigou à BrT-Oi a criar uma gerência comercial, responsável, exclusivamente pela oferta de serviços de interconexão, exploração industrial e oferta de atacado. Esta compensação não foi verificada nos outros casos.

Também com relação a esta ordem de contrapartidas, a ANATEL impôs à BrtOi uma séria de obrigações relativas à exploração industrial de linha dedicada (EILD), tais como: manter ou reduzir o percentual de EILD especial em relação ao total de solicitações 
de EILD na Região II do PGT, apresentado pela BrT, anteriomente à realização da operação; adotar ofertas comerciais de EILD, na Região I do PGO, de modo a atingir o percentual de atendimento por meio de EILD especial igual ou inferior ao da BrT, na Região II do PGO, anteriormente à operação; prestar informações sobre EILD à Agência Reguladora; e dispensar tratamento isonômico e não discriminatório a todas as operadoras de serviços de telecomunicações de interesse coletivo na oferta de EILD.

A manutenção ou redução do percentual de atendimento de EILD especial e a obrigação de prestar informações sobre EILD periodicamente à ANATEL também foram encontradas no precedente Tlf-GVT; porém, não nos demais precedentes.

Ainda nessa ordem, outras três contrapartidas foram impostas à BrT-Oi com correspondência no caso Tlf-GVT: adotar sistemas de divulgação e publicidade na Internet sobre suas ofertas de atacado; desenvolver e tornar operacional sistema para o envio de informações à ANATEL referente aos planos de serviços, promoções, vantagens e descontos ofertados aos clientes, em periodicidade diária; e desenvolver sistema de controle de fila e seqüência de atendimento a pedidos de oferta de atacado.

Estas compensações não foram identificadas nos outros casos examinados.

A décima segunda ordem de contrapartidas tratou da manutenção de postos de trabalho e se verificou tanto no caso Brt-Oi como no caso Tlf-GVT; porém, não nos demais precedentes.

A décima terceira ordem de contrapartidas prestou à questão do encerramento de litígios judiciais e administrativos entre as operadoras dos Grupos Oi e Brasil Telecom e ANATEL.

Esta contrapartida não se verificou nos outros precedentes.

III. II. 5. Análise do Exercício da Discricionariedade nas Decisões da ANATEL.

O estudo de casos empreendido demonstrou inexistir correlação direta, uniforme e lógica entre as circunstâncias fáticas e bases legais e regulatórias existentes com o resultado das deliberações do Conselho Diretor da ANATEL. 
Os parâmetros do exercício da discricionariedade nos processos decisórios da ANATEL, em matéria de transferência de controle de operadoras de serviços de telecomunicações, não puderam ser identificados com precisão. Em outras palavras, não pudemos constatar a existência de critérios concretos e objetivos destinados a nortear a Agência Reguladora em suas decisões discricionárias.

A investigação realizada em nossa análise comparativa dos casos estudados compreendeu três etapas. A primeira destinada à checagem da relação de causas e efeitos entre os critérios de análise das operações pela ANATEL e os resultados de seu processo decisório. A segunda prestante a identificar, no tempo, a evolução do comportamento e do entendimento da ANATEL e, a partir daí, a identificação de bases sólidas e objetivas de decisão ao longo do tempo. A terceira tratante de apurar a existência, o alcance e os critérios de sopesamento dos interesses em jogo nas operações apresentadas à Agência Reguladora.

Em cada uma destas etapas concluímos, em síntese, o seguinte.

Casos em que se constatou, através dos critérios de análise da ANATEL (Tabela 1), existir grande similaridade, resultaram em decisões de aprovação de teor absolutamente distintos no que tange às condições e contrapartidas fixadas pela Agência Reguladora (Tabelas 2 e 3) ou, ainda, caso em que a própria Agência Reguladora considerou inexistir quaisquer impactos regulatórios resultantes da operação, determinou compensações.

Cronologicamente não se constatou o desenvolvimento de bases paramétricas sólidas e objetivas ao longo do tempo; não obstante, tenha nos parecido existir tendência da Agência Reguladora em optar por aprovações vinculadas por condicionamentos múltiplos e contrapartidas.

Acerca dos interesses envolvidos nas operações e de seu sopesamento e definição do interesse preponderante em cada caso concreto, da mesma forma, não pudemos aferir com clareza os critérios de ponderação discricionária da ANATEL.

A seguir, explicitamos as constatações in concreto que sustentam nossas considerações. 


\section{II. 5. 1. Critérios de Análise da ANATEL versus Decisões Discricionárias da Agência Reguladora.}

A análise comparativa dos precedentes estudados evidenciou a existência de contradições internas nos processos decisórios discricionários da ANATEL. Tais incongruências prejudicaram a identificação de parâmetros concretos e objetivos de decisão discricionária da Agência Reguladora ou, em última análise, evidenciaram que tais bordes não existem.

Exemplo disso diz respeito à aprovação da operação do caso TIM-Intelig em comparação com a aprovação dos precedentes BrT-Oi, Tlf-Vivo e Tlf-GVT.

No caso TIM-Intelig a Agência Reguladora aprovou a operação com a imposição de condicionamento único (a regularização das sobreposições de outorgas em 18 meses) e sem a imposição de qualquer contrapartida.

Não obstante, a análise dos critérios de decisão da ANATEL revelou que o precedente TIM-Intelig não apresentava fatos e circunstâncias que sustentassem e justificassem a não imposição de outros condicionamentos e contrapartidas a essa operação, em relação as condições e compensações fixadas pela Agência Reguladora nos precedentes BrT-Oi, Tlf-Vivo e Tlf-GVT.

Em outras palavras, tal como nestes últimos precedentes, no caso TIM-Intelig, a ANATEL verificou a existência de sobreposição de outorgas, o acúmulo de CSP (ainda que não mencionado nas Análises), a inexistência de acúmulo de radiofrequências, a inexistência de indícios de participação cruzada ou controle vedado na regulamentação e a possível existência de sinergias operacionais e administrativas e economias de escala. Todos estes fatos foram, também, constatados nos precedentes BrT-Oi, Tlf-Vivo e TlfGVT.

Especificamente sobre os aspectos concorrenciais no caso TIM-Intelig se verificou a concentração de mercados sem impactos significativos no STFC e no SCM e ausência de qualquer impacto concorrencial no SMP. Realidade essa analogamente similar a constatada no caso Tlf-GVT, em que se constatou concentração de mercado sem impactos significativos no STFC e ausência de concentração de mercado no SCM. Neste aspecto o caso Tlf-Vivo não apresentava qualquer impacto concorrencial e, por sua vez, o 
caso Brt-Oi apresentava uma série de impactos diversificados a depender do segmento de mercado.

Ainda outros dois critérios de decisão da Agência Reguladora coincidiam entre esses três precedentes e o caso TIM-Intelig: inexistência de risco de descumprimento das obrigações contratuais e ausência de demonstração de benefícios diretos aos usuários de serviços de telecomunicações das operadoras envolvidas nas operações.

É dizer, assim, em que se pese as especificidades da análise concorrencial de cada caso, que em todos os critérios de decisão da ANATEL, o caso TIM-Intelig não destoou dos precedentes BrT-Oi, Tlf-Vivo e Tlf-GVT; em verdade, os pontos de checagem da ANATEL (vide Tabela 1) apresentaram resultados bastante similares - senão idênticos nesses precedentes; contudo, no primeiro caso a Agência Reguladora não impôs condicionamentos para além da regularização de sobreposição de outorgas e não se lhe infligiu qualquer contrapartida. Enquanto que nos três outros precedentes apontados uma gama de condicionamentos e contrapartidas foram cominados como demonstramos nas Tabelas 2 e 3 , respectivamente.

Por que no caso TIM-Intelig a ANATEL não fixou outros condicionamentos e contrapartidas tal como no caso BrT-Oi? Por que, em seguida, voltou a fixar-las nos casos Tlf-GVT e Tlf-Vivo?

A Análise n. ${ }^{\circ} 43 / 2009-G C J R$, de 27/07/2009, do caso TIM-Intelig em nada é esclarecedora. Não há neste documento qualquer justificativa que sustente a não imposição de outros condicionamentos e contrapartidas à operação. Não há, na mesma medida, referência a precedentes positivos ou negativos que fundamentem a não atribuição de condições e compensações à aprovação da operação. Esta Análise, portanto, não aporta informações que possibilitem compreender porque a ANATEL discricionariamente decidiu por aprovar a operação sem infligir-lhe outros condicionamentos ou contrapartidas.

Outro exemplo resultante de nosso estudo de casos refere-se à incongruência da ANATEL no caso Tlf-Vivo. Neste precedente a própria ANATEL reconhece que a operação se trata apenas de mera consolidação de controle societário do Grupo Telefonica sobre o Gupo Vivo e, bem assim, que por esta razão a concretização da operação não ocasionaria qualquer impacto mercadológico ou regulatório. 
Porém, valendo-se da voluntariedade do Grupo Vivo em assumir compromissos junto à ANATEL, para favorecer o atendimento aos usuários e a ampliação de cobertura dos serviços prestados, para além das obrigações já assumidas com a Agência Reguladora, quer seja por meio dos instrumentos de outorga, quer seja por obrigação legal e regulatória, a ANATEL não só concordou com as promessas realizadas pelo Grupo Vivo, como também, estipulou prazos para o seu cumprimento, acrescentou mecanismos de fiscalização e as transformou em condicionamentos à operação.

Nesta qualidade, de condicionar a operação, o seu descumprimento passa a sujeitar as empresas às sanções de caráter administrativo e judicial e a reversão da operação aprovada pela ANATEL, tal qual informado ao Grupo Vivo, por meio do Ato n. ${ }^{\circ}$ $6.235 / 2010\left(\operatorname{art.} 3^{\circ}\right)$.

O expresso reconhecimento do regulador de que a operação está conforme a regulamentação e de que esta não produz impactos regulatórios significativos aliada a imposição de contrapartidas à operação - ainda que originadas de compromissos voluntários do Grupo Vivo - evidencia a inexistência de qualquer parâmetro objetivo para uso da discricionariedade pela ANATEL nos processos decisórios dos casos de transferência de controle de operadoras de serviços de telecomunicações.

Frise-se, ademais, que também neste caso, não houve referência a precedentes positivos, que justificassem a imposição de contrapartidas às empresas como, por exemplo, ao caso BrT-Oi.

A consolidação de algum parâmetro da ANATEL poderia advir exatamente em sentido contrário, o da não imposição de qualquer condicionamento ou contrapartida ao caso Tlf-Vivo. Caso assim tivesse ocorrido poderíamos ter constatado algum padrão de decisão da Agência Reguladora com relação a outros precedentes em que a ANATEL aprovou as operações de transferência de controle sem a imposição de condicionamentos e contrapartidas.

Neste ponto, teria lugar também o raciocínio inverso ao realizado anteriormente, isto é, quais seriam os parâmetros para que a ANATEL aprovasse a operação TIM-Intelig sem a cominação de condicionamentos (além da regularização da sobreposição de outorgas) e contrapartidas e os impusesse no caso Tlf-Vivo reconhecidamente sem impactos regulatórios? 
O manejo da discricionariedade pela ANATEL nos processos decisórios dos casos de transferência de controle de operadoras de serviços de telecomunicações parece ainda mais fortuito quando trazemos à tona um último exemplo referente ao caso Tlf-GVT.

Nesse caso, a ausência de parâmetros claros para a decisão discricionária da ANATEL pode ser evidenciada, na medida em que a Análise do Conselheiro Relator Antonio Domingos Teixeira Bedran, especificamente com relação aos termos de aprovação da operação, foi substituída após deliberação do Conselho Diretor da Agência Reguladora.

Para o relator, a princípio, eventuais condicionamentos ou restrições à operação poderiam vir a ser fixados por ocasião do exame de Ato de Concentração a ser analisado pela Agência Reguladora; de modo, que este recomendou a aprovação prévia da operação ao Conselho Diretor sem cominação de outras condições - para além da regularização das sobreposições de outorgas e do acúmulo de CSPs - ou contrapartidas. Porém, o Conselheiro Ronaldo Mota Sardenberg entendeu e, nesse sentido, foi posteriormente acompanhado pela maioria do Conselho Diretor da Agência Reguladora, que deveriam ser impostos condicionamentos e contrapartidas à Telefonica.

A fundamentação do Conselheiro Ronaldo Mota Sardenberg é sintética e longe de ser clara. Deveras, não há parâmetros em que basear sua decisão. De todo modo, o Conselheiro faz menção à monta da operação e ao fato de envolver uma concessionária e a empresa-espelho mais bem sucedida do processo de desestatização setorial. Utiliza, além disso, argumentação finalística avocando o dever da ANATEL propiciar a competição, impedir a concentração de mercado e a diversidade de serviços.

Não faz, ainda, menção a outros precedentes da Agência Reguladora que sustentariam a imposição de condicionamentos e contrapartidas neste caso. Não obstante, importa aleatoriamente algumas das condições e compensações impostas no caso BrT-Oi, como a neutralidade de redes e a melhoria de atendimento e de índices de atendimento das ofertas de atacado, sem as justificar e explicitar sua relação e proveito neste caso.

Por que alguns condicionamentos e contrapartidas do caso BrT-Oi foram impostos neste caso e outros não? Quais foram os critérios de escolha das restrições e compensações impostas neste caso? Não foi possível compreender. 
Mais uma vez, a ausência de parâmetros definidos, claros e objetivos não nos permitiu decifrar as razões que embasaram a decisão discricionária da ANATEL neste caso e evidenciou que nem mesmo entre os conselheiros da Agência Reguladora há certeza quanto aos melhores termos da decisão a ser proferida, haja vista que não existem referenciais a guiar o exercício da discricionariedade nos processos decisórios da ANATEL.

\section{II. 5. 2. A Cronologia das Decisões da Agência Reguladora.}

A análise temporal do exercício da discricionariedade nos processos decisórios da ANATEL, nos casos estudados, da mesma forma, não evidenciou existir sólidos parâmetros de decisão e relação referencial entre os casos decididos ao longo do tempo pela Agência Reguladora.

Em linha temporal, esse foi o resultado de nossa investigação:

Avaliação Temporal das Decisões da ANATEL em Matéria de
Transferência de Controle de Operadoras de Serviços de
Telecomunicações

[página seguinte] 


\begin{tabular}{|c|c|c|c|c|c|}
\hline MÊS/ANO & NOV/2003 & DEZ/2008 & AGO/2009 & NOV/2009 & SET/2010 \\
\hline PRECEDENTE & Vesper-EBT & Brt-Oi & TIM-Intelig & $T l f-G V T$ & Tlf-Vivo \\
\hline APROVAÇÃO & $\mathbf{X}$ & $\mathbf{X}$ & $\mathbf{X}$ & $\mathbf{X}$ & $\mathbf{X}$ \\
\hline $\begin{array}{c}\text { CONDICIONAMENTO } \\
\text { ÚNICO }\end{array}$ & $\mathbf{X}$ & & $\mathbf{X}$ & & \\
\hline $\begin{array}{c}\text { MÚLTIPLOS } \\
\text { CONDICIONAMENTOS }\end{array}$ & & $\mathbf{X}$ & & $\mathbf{X}$ & $\mathbf{X}$ \\
\hline CONTRAPARTIDAS & & $\mathbf{X}$ & & $\mathbf{X}$ & $\mathbf{X}$ \\
\hline
\end{tabular}

Fonte: Elaboração própria.

A tabela acima demonstra que a partir de 2008 poderia existir algum padrão nos processos decisórios da ANATEL, uma vez que desde então preponderou as decisões com imposição de condicionamentos múltiplos e contrapartidas.

Seria esta a tendência da ANATEL?

Não nos parece possível, contudo, afirmar que esta seja a tendência da ANATEL. Isto porque dois precedentes romperam com qualquer linearidade que pudesse existir nos posicionamentos da Agência Reguladora. 
A primeira ruptura ocorreu com o precedente TIM-Intelig, de agosto de 2009, em que de acordo com o posicionamento da ANATEL no precedente de 2008, seria razoável esperar-se que a Agência Reguladora lhe impusesse condicionamentos múltiplos e contrapartidas tal qual no caso anterior. Não foi o que ocorreu.

A segunda ruptura deu-se com a cominação de condicionamentos múltiplos e contrapartidas no precedente Tlf-Vivo, de 2010, sem qualquer fundamentação legal ou regulatória, quando em consonância com o precedente de 2003 dever-se-ia esperar a aprovação com condicionamento exclusivo acerca da regularização de outorgas.

Estes dois precedentes funcionaram, em verdade, como antipadrão decisório.

Desta forma, concluímos que, embora, em um primeiro momento possa parecer que ao longo do tempo a ANATEL venha consolidando seu posicionamento no sentido de impor múltiplos condicionamentos e contrapartidas às operações que lhes são apresentadas, não se pode fazer qualquer previsão a este respeito. As decisões da ANATEL, acerca do objeto deste estudo de casos, são, ainda, incertas. Isto porque, ao longo do tempo, não identificamos evidências de que tais decisões tenham sido exaradas com base em quaisquer parâmetros concretos e objetivos, ao longo do tempo.

Não há, no tempo, assim, uma evolução clara e coerente do entendimento da ANATEL; de modo que, não foi possível constatar a existência e o aperfeiçoamento de parâmetros à discricionariedade da Agência Reguladora em seus processos decisórios.

\section{II. 5. 3. A Identificação e o Sopesamento dos Interesses Envolvidos nos Precedentes da ANATEL.}

A última etapa de nossa investigação acerca dos parâmetros a embasar as escolhas discricionárias da ANATEL em seus processos decisórios pautou-se na análise da identificação e do sopesamento dos interesses envolvidos em cada caso submetido à aprovação prévia da Agência Reguladora.

A este respeito, constatamos que, de maneira geral, a ANATEL não identificou com objetividade e clareza quais os interesses envolvidos em cada operação, tampouco realizou o seu sopesamento de maneira transparente e motivada. 
Pareceu-nos que os documentos analisados refletiram certa timidez da ANATEL neste sentido; timidez tamanha que nos levou a crer que o sopesamento de interesses pela Agência Reguladora em seus processos decisórios é ainda um tabu.

Merece destaque, a este respeito, apenas o precedente Vésper-EBT em que a ANATEL ousou um pouco mais e, pois, evidenciou a realização de algum sopesamento dos interesses envolvidos neste caso, embora não tenha explicitado os parâmetros de sua decisão discricionária.

O caso Vésper-EBT apresentava três peculiaridades: óbice legal (art. 68 da LGT), risco de descumprimento dos instrumentos contratuais pela Vésper S.A. e Vésper São Paulo S.A. e benefício diretos dos usuários da operadora com a concretização da operação.

Diante destas particularidades, o Conselheiro Relator, Marcos Bafutto, ponderou que, não obstante como resultado da operação ter-se-ia a redução de competidores no mercado de STFC, a aprovação da operação poderia resguardar o direito de 500 mil usuários dos serviços de telecomunicações da Vésper, uma vez que possibilitaria a continuidade da prestação desses por meio de outra operadora

Em síntese, a operação contrapunha de um lado, a mantença do modelo de competição para o mercado de STFC pré-estabelecido no processo de desestatização e, de outro, os benefícios aos usuários do serviço, decorrentes da continuidade de sua prestação.

Ante este cenário, ocasionado pela débil saúde financeira da Vésper à época, a ANATEL optou por flexibilizar a rigidez do modelo concebido em prol das eficiências provenientes da operação que lhe era submetida, especialmente a preservação dos interesses dos usuários da Vésper, recorrendo-se, pois, ao caráter finalístico da Resolução n. ${ }^{\circ} 101 / 99$.

A Análise n. ${ }^{\circ}$ 003/2003 - GCMB, de 18/11/2003, não apresenta de maneira explícita e aprofundada o processo de sopesamento dos interesses em jogo realizadas pelo Conselheiro e aprovadas, por unanimidade pelo Conselho Diretor da ANATEL. Mas é fato que tal sopesamento foi realizado. 
Ao que nos interessa, todavia, em razão da ausência de motivação do referido sopesamento de interesses não foi possível identificar com que parâmetros este foi realizado no caso concreto.

Veja-se, a este respeito, que não basta que o regulador indique genericamente que é seu dever zelar pelo interesse público para que se possa afirmar a existência de algum parâmetro decisório. Afinal, como vimos em nosso Capítulo I, a avocação da concepção de supremacia do interesse público sobre o interesse privado não é mais suficiente para atender as exigências de motivação do Estado contemporâneo.

\section{II. 6. Conclusões.}

O estudo de casos empreendido demonstrou que as decisões discricionárias da ANATEL carecem de parâmetros concretos e objetivos que possibilitem o acompanhamento da construção da decisão do regulador pelos interessados e dificultam se não obstam - a sua confrontação judicial, quando necessária.

Com efeito, não há transparência com relação aos critérios de decisão da Agência Reguladora e não há referencial lógico-casuístico que auxilie os conselheiros da ANATEL no exercício de seu poder discricionário nos processos decisórios destes casos.

Mais que isso, a ausência de qualquer referencial acerca das decisões discricionárias da Agência Reguladora as torna absolutamente imprevisíveis e espraia a incerteza e insegurança jurídica no setor de telecomunicações, o que acaba por solapar o objetivo de certeza e segurança buscado com a moderna regulação.

Esse cenário é ainda mais grave na medida em que se sabe que as decisões regulatórias discricionárias da ANATEL têm grande impacto econômico no mercado de telecomunicações e adjacentes, bem como, impactam indiretamente nas políticas públicas setoriais, nos programas de infra-estrutura, no desenvolvimento tecnológico, científico e industrial.

Avocar simplesmente os deveres da ANATEL, como propiciar a competição, impedir a concentração econômica do mercado e promover a diversidade de serviços, a nosso ver, não é suficiente para embasar a escolha discricionária da ANATEL sobre qual o interesse prevalecente em cada caso. 
Especificamente no que tange à ANATEL, ademais, evidencia-se ampla possibilidade que se afirme uma ou outra decisão da Agência Reguladora exclusivamente com base na discricionariedade técnica, em razão da tecnicidade de diversos aspectos de sua atuação. Contudo, diversos são os interesses em jogo sopesados pela ANATEL em seu agir diário. A deferência às políticas públicas setoriais e à política de governo vigente, as pressões de grupos econômicos e de representantes dos mais diversos grupos de operadores e a busca por curar os interesses dos usuários potenciais e efetivos dos serviços de telecomunicações é uma constante nos processos decisórios da ANATEL.

Em vista de tantos interesses legítimos simultâneos - que convivem, mas que não se compatibilizam necessariamente - a escolha pública por um em detrimento de outro é efetivamente discricionária (muitas vezes sem critérios técnicos, ou porque esses não são relevantes no caso concreto, ou porque, como vimos no Capítulo III, mesmo quando existentes podem ser desconsiderados pela ANATEL) e, por isso mesmo, deve pautar-se em parâmetros objetivos que possibilitem o seu acompanhamento e contestação.

Contudo, perante o cenário identificado neste estudo de casos, concluímos que o processo decisório discricionário da ANATEL é imprevisível e incerto, carente de bases objetivas aferíveis e conferíveis pelos interessados e pelo Poder Judiciário.

O acompanhamento do processo decisório pelos interessados e, bem assim, o controle judicial das decisões discricionárias da ANATEL revelam-se, assim, tarefa impraticável em razão da ausência de parâmetros sólidos e objetivos para a sua confrontação.

Como vimos anteriormente, é necessário que à amplitude da discricionariedade das Agências Reguladoras - e considerando especialmente, mas não só, sua atuação na mediação ativa de interesses legítimos contrapostos - correspondam mecanismos efetivos e eficazes de controle de suas decisões discricionárias.

O diagnóstico, entretanto, com relação à ANATEL, no que tange aos processos decisórios, de cunho declaratório, na matéria de transferência de controle de prestadoras de serviços de telecomunicações, não é nada alentador. Ao contrário, aferimos, em conclusão, que as decisões discricionárias da Agência Reguladora não apresentam fundamentos objetivos sólidos, tampouco se expressam através de critérios paramétricos concretos. Em outras palavras, há absoluta aleatoriedade no decidir discricionariamente da ANATEL. 
Esta ordem de fatores, aliada a alguma resistência doutrinária para o controle do mérito do ato administrativo (e, pois, regulatório) e a resistência (senão omissão) do Poder Judiciário assumir o integral controle das decisões administrativas discricionárias, como veremos no próximo capítulo, completam o quadro favorável à perpetuação do arbítrio da Administração Pública (e da autoridade pública) inadmissíveis em um Estado de Direito.

O estabelecimento de parâmetros objetivos para o acompanhamento do processo decisório discricionário das Agências Reguladoras - e especificamente da ANATEL - e para a confrontação da decisão administrativa discricionária em âmbito judicial revela-se de suma importância para a proteção e garantia dos direitos dos regulados. Funciona, ainda, como um prévio agente inibidor de arbitrariedades e fomentador do comprometimento da autoridade pública que em seu agir saberá, de antemão, que sua escolha por um ou outro interesse em jogo no caso concreto, poderá, passo a passo, ser conferida. É o que trataremos no último capítulo da dissertação. 
PARTE III - EM BUSCA DA DETERMINAÇÃO DOS MOTIVOS DAS DECISÕES REGULATÓRIAS DISCRICIONÁRIAS 


\section{NOTA PRELIMINAR}

Assentadas as bases conceituais em que se fundam nossas preocupações na PARTE I, marcadamente, na multiplicidade de interesses legítimos coexistentes na sociedade contemporânea, na alta complexidade e na tecnicidade das relações sociais e econômicas, no advento do Estado Mediador imbuído do dever de ponderar os conflitos de interesses legítimos, no incremento da discricionariedade estatal e na ampliação do conceito de legalidade para a juridicidade.

E diagnosticadas as dificuldades daí decorrentes na PARTE II, especialmente, o risco do arbítrio e do desvio de poder do administrador e, modernamente, da captura do regulador, a fragilidade do administrado e a sua condição de hiposuficiência em face de decisões regulatórias discricionárias desparametrizadas.

Dedica-se a PARTE III dessa dissertação a apresentar o tema do controle judicial dos atos administrativos, notadamente no viés de sua extensão e alcance com relação aos atos regulatórios discricionários (Capítulo IV) e a propor parâmetros concretos e objetivos de controle das decisões discricionárias das Agências Reguladoras e, pontualmente, da ANATEL (Capítulo V).

Os capítulos derradeiros da dissertação intentam comprovar (Capítulo IV) e instrumentalizar (Capítulo V) as hipóteses de trabalho que serviram de móvel deste trabalho:

(i) A discricionariedade nos processos decisórios declaratórios das Agências Reguladoras, no âmbito do exercício da mediação ativa de interesses, não é incondicionada e ilimitada.

(ii) As escolhas administrativas (e regulatórias) discricionárias devem ser previsíveis e passíveis de amplo e objetivo controle pelos interessados $e$ pelos órgãos de fiscalização, especialmente, pelo Poder Judiciário. 
Nesse mister, os capítulos subsequentes buscam apresentar elementos que permitam responder ao questionamento-chave da dissertação:

- Como enfrentar o risco de escolhas discricionárias arbitrárias do regulador?

O enfrentamento dessa questão passa por algumas indagações precedentes:

(iii) Em que medida os atos administrativos (e regulatórios) discricionários são controláveis pelo Poder Judiciário?

(iv) Como auferir, em cada caso concreto, se a decisão discricionária regulatória, no exercício da mediação ativa de interesses legítimos, é a melhor solução juridicamente possível?

Estes questionamentos têm lugar em um cenário em que se reconhece ao regulador o gozo de discrição para a ponderação de interesses legítimos contrapostos. Trata-se de um ambiente propício ao arbítrio, ao desvio de poder e à captura do regulador.

Floriano de Azevedo MARQUES NETO bem assevera que, no contexto de colidência entre interesses legítimos contrapostos e de opção e seleção desses, por parte da Administração Pública, o controle de discricionariedade passa a ser questão central para $o$ Direito. ${ }^{259} \mathrm{~A}$ importância do controle de discricionariedade, explica o autor, não se revela apenas pela necessidade de controlar o preenchimento das lacunas dos textos normativos, mas ainda, muitas vezes, pela obrigatoriedade de controlar a discricionariedade na eleição de um determinado interesse a ser privilegiado na ação estatal em detrimento de outro interesse, de mesma natureza e legitimidade que aquele

O risco regulatório decorrente da maior margem de discricionariedade acometida ao regulador na sociedade contemporânea, tal como vimos em nosso Capítulo II, e a relevância do controle judicial como instrumento de fiscalização do manejo da discricionariedade do agente público são, assim, captados pelo autor:

${ }^{259}$ Cf. Floriano de Azevedo MARQUES NETO. Discricionariedade Administrativa e Controle Judicial da Administração, p. 191 e ss. 
"Se temos maior margem de discricionariedade cometida ao agente público, necessariamente deveremos ter meios de controlá-la para evitar que pela porta dos fundos adentrem interesses particularísticos, os interesses ilegítimos e que, sobre a égide de dizer que há um interesse público sendo atendido, comecem a ser consagrados apenas interesses de parcelas da sociedade, interesses que não se legitimam à luz da coletividade. Portanto, se a lei não consegue mais prever, a priori, de maneira precisa, os limites da atuação política e cada vez mais é necessária a mediação de interesses públicos logo cada vez é mais importante que haja um controle forte, presente, do exercício dessa atividade discricionária. " 260 (grifos nossos)

O desafio que se revela, portanto, hodiernamente, é como controlar o exercício da discricionariedade pela Administração Pública - ou mais precisamente no que nos interessa, pelo regulador - de modo a que a decisão regulatória discricionária mostre-se a melhor solução juridicamente possível ${ }^{261}$ ao caso concreto.

O controle da Administração Pública é analisado pela doutrina sob os mais diversos aspectos ${ }^{262}$, dos quais decorre uma série de classificações sobre a matéria. ${ }^{263}$

A especial importância do controle judicial dos atos administrativos é observada amplamente pela doutrina.

${ }^{260}$ Floriano de Azevedo MARQUES NETO. Discricionariedade Administrativa e Controle Judicial da Administração, p. 191.

${ }^{261}$ Cumpre esclarecer, desde já, a que entendemos corresponder tal expressão; não obstante, ao longo da PARTE III completemos o seu sentido ao apresentar os parâmetros que pautam uma decisão desse quilate. De maneira geral, utilizamos a expressão "melhor solução juridicamente possível" para designar uma decisão que, além de cumprir com todos os requisitos de legalidade, mostrou-se resultante de amplo e transparente processo decisório, fruto de diálogo e confrontação racional entre os interessados e entre esses e a Agência Reguladora, deferente aos seus precedentes, motivada positiva e negativamente e que proporcionou, senão à compatibilização ótima de todos os interesses envolvidos, o equilíbrio ideal entre o interesse satisfeito e o interesse sacrificado.

${ }^{262}$ A principal classificação diz respeito ao órgão que realiza o controle. Por essa classificação pode-se falar em controle interno e externo. O primeiro seria o autocontrole da Administração pública e o segundo seria realizado por outrem, subdividido, assim, em controle político e controle social. Para uma visão dos diversos tipos de controle sobre a atuação das Agências Regulador ver Marçal JUSTEN FILHO. O Direito das Agências Reguladoras Independentes, p. 584 e ss. Ver, também, Sérgio GUERRA. Controle Judicial dos Atos Regulatórios, p. 247-261.

${ }^{263}$ Preferimos a classificação apresentada por Floriano de Azevedo MARQUES NETO em três planos: o do controle conforme os interesses envolvidos, o do controle conforme a atividade do regulador e o do controle conforme os órgãos competentes para o seu exercício. Agências Reguladoras Independentes Fundamentos e seu Regime jurídico, p. 111 e ss. 
Como salienta Odete MEDAUAR o controle judicial continua a ser o instrumento mais importante de controle da Administração Pública, apesar da busca de outros meios que possam suprir as falhas ou dificuldades deste controle. ${ }^{264}$

Maria Sylvia Zanella DI PIETRO, por sua vez, acentua que o controle judicial, juntamente com o princípio da legalidade, constitui um dos fundamentos em que repousa o Estado de Direito. Afirma a autora que de nada adiantaria sujeitar-se a Administração Pública à lei se seus atos não pudessem ser controlados por um órgão dotado de garantias de imparcialidades que permitam apreciar e invalidar os atos ilícitos por ela praticados. ${ }^{265}$

Interessa-nos, todavia, para os fins desta dissertação, exclusivamente, o controle judicial $^{266}$ dos atos regulatórios ${ }^{267}$, resultantes dos processos decisórios, de cunho declaratório, das Agências Reguladoras e, pois, especificamente da ANATEL.

Impõem-se às Agências Reguladoras, conquanto entes pertencentes à Administração Pública indireta, o controle judicial de todas as suas atividades e atos regulatórios, tal qual ocorre com o Poder Público em geral.

O tema ganha relevância e complexidade, nesse sentido, quando analisado sob o enfoque do controle judicial da intervenção regulatória estatal no domínio econômico privado.

Com efeito, as Agências Reguladoras surgiram como mecanismos de intervenção e controle estatal sobre setores específicos da economia; e se prestam, de maneira geral, a assegurar, concomitantemente, a exploração de uma dada atividade econômica e a consecução de objetivos públicos consentâneos com os princípios da ordem econômica fixados na Constituição Federal, especialmente aqueles previstos em seu art. $170 .{ }^{268}$

\footnotetext{
${ }^{264}$ Direito Administrativo Moderno, p. 392.

265 Direito Administrativo p. 708.

${ }^{266}$ Não iremos abordar os aspectos processuais que envolvem o tema, haja vista não ser esse nosso foco nesta dissertação.

267 Nosso foco nessa terceira parte é tratar dos atos regulatórios discricionários e, especificamente das decisões regulatórias discricionárias. Entendemos, entretanto, que esses são espécies dos atos administrativos e das decisões administrativas discricionárias. Razão pela qual trabalharemos com essas noções concomitantemente e, quando, pertinente nos referiremos apenas ao universo específico da regulação.

268 Sobre o tema ver, por todos, Floriano de Azevedo MARQUES NETO. Agências Reguladoras Independentes: Fundamentos e seu Regime Jurídico.
} 
Nesse mister, os efeitos da regulação podem alcançar não só os agentes e os usuários potenciais e efetivos dos serviços abarcados no mercado regulado, mas também, indiretamente, agentes e usuários de mercados adjacentes e políticas públicas e governamentais destinadas a outros setores e segmentos. Exemplo claro do que afirmamos são os impactos freqüientes da regulação do setor de telecomunicações nos segmentos de indústria e tecnologia.

Os impactos da decisão judicial poderão, também, por conseguinte, alcançar esse mesmo universo. Mas, mais que isso, discute-se acerca do controle judicial das decisões regulatórias discricionárias, especialmente, se esse reduz a efetividade da regulação e, se por meio desse controle, o Poder Judiciário substitui o regulador naquilo que esse tem de mais caro, a tecnicidade.

Parece-nos, particularmente, que os anseios e temores de todos que estudam o tema são semelhantes e podem ser resumidos na busca pelo controle da atividade administrativa e regulatória discricionária sem que o Poder Judiciário substitua o regulador.

Para tanto, entendemos que é necessário que se estabeleçam parâmetros concretos que orientem a Administração Pública (e, pois, as Agências Reguladoras) e os interessados ao longo do processo decisório e ao Poder Judiciário no âmbito do exercício de sua atividade de controle. Esses parâmetros permitiriam a aferição, em cada caso concreto, da correção e adequação das decisões regulatórias da ANATEL e, bem assim, da adoção ou não da “melhor solução juridicamente possível” pelo regulador.

Com vistas a essa finalidade quatro são os parâmetros que apresentaremos no Capítulo V: (i) a vinculação aos precedentes da ANATEL; (ii) a motivação positiva e negativa de todos os atos do processo decisório; (iii) a transparência do processo decisório; e (iv) a efetividade e o prognóstico da efetividade das decisões regulatórias discricionárias.

Estes parâmetros, como veremos, pressupõem a racionalização e a processualização das decisões regulatórias discricionárias e expressam-se em testes à atuação do regulador. 
Acreditamos que esses parâmetros contribuiriam, assim, para a segurança jurídica (previsibilidade e estabilidade) das relações entre a Administração Pública e os administrados ou, especificamente, entre as Agências Reguladoras e os regulados. E, ademais, resguardariam os direitos dos interessados, direcionariam as escolhas públicas, inibiriam o arbítrio do regulador e auxiliariam o Poder Judiciário no controle judicial das decisões regulatórias discricionárias.

Como enunciamos, inicialmente, estes temas serão, pois, objeto dessa PARTE III da dissertação. 


\section{CAPÍTULO IV - O CONTROLE JUDICIAL DAS DECISÕES REGULATÓRIAS DISCRICIONÁRIAS}

\section{1. Introdução.}

A questão mais relevante no que concerne ao tema do controle judicial das decisões da Administração Pública diz respeito ao alcance da fiscalização a ser exercida pelo Poder Judiciário nos atos administrativos discricionários, uma vez que com relação aos atos administrativos vinculados há consenso na doutrina administrativista no sentido de que o seu controle judicial encontra seus limites estritamente na lei.

Os limites de atuação do Poder Judiciário para controlar os atos administrativos discricionários e, contemporaneamente, os atos regulatórios discricionários têm sido objeto de inúmeros trabalhos na doutrina pátria e estrangeira.

O debate está localizado na compatibilização de institutos basilares do Estado de Direito, quais sejam: a subsunção da Administração Pública à Constituição Federal e às Leis, a inafastabilidade da tutela jurisdicional de qualquer lesão ou ameaça de direito dos administrados e a separação de poderes estatais. ${ }^{269}$

Duas são as vertentes doutrinárias acerca do tema.

Uma é favorável ao controle restrito dos atos administrativos, que se circunscreve à legalidade do ato. De acordo com Odete MEDAUAR o argumento que

\footnotetext{
269 Adotamos nesta dissertação as lições de Floriano de Azevedo MARQUES NETO a respeito da prestabilidade da separação de poderes estatais. Nas palavras do jurista "o poder estatal é uno e se manifesta de diferentes formas. A tripartição de poderes não importa, portanto, em uma divisão funcional do poder estatal, mas apenas na obrigatoriedade de que o poder estatal seja escalonado em momentos, em fases distintas, alocadas cada qual em um núcleo orgânico diferente. É dizer, no devir da manifestação do poder estatal, a tripartição de poderes obriga que haja um encadeamento temporal de funções, de modo a que a manifestação geral e abstrata (função legislativa) seja pressuposto antecedente da manifestação do poder estatal, a manifestação concreta, geral ou específica (função judiciária), seja sempre a ela subseqüente e a função de implementação seja a ela subsidiária, é dizer, prestante a concretizar as manifestações abstratas do Legislativo ou do Judiciário. A tripartição de poderes impõe, portanto, um encadeamento de funções para legitimar as diferentes manifestações do poder estatal, nas suas variadas formas." (grifos nossos) Ensaio sobre o Processo como Disciplina do Exercício da Atividade Estatal, 264-265. No mesmo sentido Marcos Paulo VERISSIMO assevera que "se definir os limites e características dessas funções já era tarefa ingrata no passado, hoje essa tarefa é ainda mais difícil” (...) "[a] busca de limites, hoje, somente parece ser viável, somente parece fazer sentido, se for focada na instituição, não mais na função." Controle Judicial da atividade Normativa das Agências de Regulação Brasileiras, p. 410-411.
} 
sustentaria esse posicionamento seria a impossibilidade de ingerência do Poder Judiciário em atividades típicas do Poder Executivo, ante o princípio da separação de poderes. De acordo com essa linha, no controle dos atos administrativos o Poder Judiciário apreciaria somente matéria relativa à competência, forma e licitude do objeto. ${ }^{270}$

E, outra, é partidária do controle amplo dos atos administrativos, cujo fundamento, ainda segundo a autora, seria o de que a finalidade do princípio da separação de poderes seria precisamente a contenção recíproca de poderes, cabendo ao Poder Judiciário o controle jurisdicional da Administração Pública, sem que se pudesse cogitar de ingerência indevida.

As discussões sobre o tema renovam-se no âmbito dos atos regulatórios discricionários. Isso porque outros elementos, intrínsecos às Agências Reguladoras, tais como a discricionariedade técnica e os impactos econômicos de suas decisões, alimentam as discussões acerca da extensão do controle judicial das decisões regulatórias discricionárias.

Sem o propósito de simplificar o farto debate acerca dos limites do controle judicial dos atos administrativos discricionários e, especificamente, dos atos regulatórios discricionários, o presente capítulo volta-se à apresentação do tema tal como tratado na doutrina administrativista.

\section{2. O Estado de Direito.}

Pareceu-nos ao longo dos estudos acerca do tema do controle judicial das decisões regulatórias discricionárias que a sua abordagem não poderia prescindir de um breve retorno às origens, à noção primeira de Estado de Direito. ${ }^{271}$

Essa percepção nos ocorreu ao buscarmos argumentos que sustentassem a tese de amplo e objetivo controle das decisões regulatórias discricionárias.

Assim, convém recordar que o Estado de Direito é a consagração jurídica de um projeto político em que se estratificou o objetivo de garantir e assegurar os cidadãos

\footnotetext{
${ }^{270}$ Direito Administrativo Moderno, p. 394.

${ }^{271}$ Para um aprofundamento sobre o tema da sujeição do poder público ao direito ver Gaspar ARIÑO. Derechos del Rey, Derechos del Pueblo. Actas de Historia de la Administración.
} 
contra as intemperanças do Poder Público, mediante a sua prévia subordinação (e de seus agentes) a um quadro normativo geral e abstrato cuja função precípua é conformar efetivamente a conduta estatal a certos parâmetros estabelecidos como forma de preservação dos administrados. ${ }^{272}$

Carlos Ari SUNDFELD, em suas primeiras lições de Fundamentos de Direito Público, ensina que o Estado de Direito é um Estado que realiza suas atividades debaixo da ordem jurídica, contrapondo-se ao Estado-Polícia, onde o poder político era exercido sem limitações jurídicas, apenas se valendo de normas jurídicas para se impor aos cidadãos. ${ }^{273}$

Balladore PALLIERI precisamente sintetiza essa noção ao afirmar que em um Estado de Direito este deve estar submetido, como qualquer outro sujeito, às leis e à jurisdição. ${ }^{274}$

É, pois, propósito do Estado de Direito estabelecer um real empecilho a que tais limites sejam ultrapassados, porém, se o forem, assegurar que tais comportamentos violadores do Direito sejam fulminados. ${ }^{275}$

Pressupõe-se, para tanto, que exista um órgão independente, ao qual os lesados por atuação ilegítima estatal possam, recorrer para a dicção do Direito e, conseqüentemente, sujeitar o Estado aos termos estabelecidos no ordenamento jurídico. ${ }^{276}$

O Estado de Direito é, nesse sentido, definido por Carlos Ari SUNDFELD como o criado e regulado por uma Constituição, onde o exercício do poder político é dividido entre órgãos independentes e harmônicos, que controlem uns aos outros, de modo que a lei produzida por um deles tenha de ser necessariamente observada pelos demais e que os cidadãos, sendo titulares de direitos, possam opô-los ao próprio Estado. ${ }^{277}$

\footnotetext{
${ }^{272}$ Cf. Celso Antônio BANDEIRA DE MELLO. Controle Judicial dos Atos Administrativos, p. 65.

${ }^{273}$ Fundamentos de Direito Público, p. 36.

${ }^{274}$ Diritto Costituzionale, p. 85. Apud: Celso Antonio BANDEIRA DE MELLO. Controle Judicial dos Atos Administrativos, p. 65.

${ }^{275}$ Cf. Celso Antônio BANDEIRA DE MELLO. Controle Judicial dos Atos Administrativos, p. 65.

${ }^{276}$ Cf. Celso Antônio BANDEIRA DE MELLO. Controle Judicial dos Atos Administrativos, p. 65.

${ }^{277}$ Fundamentos de Direito Público, p. 38.
} 
É o que Norberto BOBBIO identifica como Estado de Direito em sentido forte, no qual mecanismos constitucionais impedem ou desencorajam o abuso ou exercício ilegal do poder. ${ }^{278}$

Reconhecido que é, destarte, o propósito do Estado de Direito submeter a Administração Pública, impedindo-a de converter-se em arbítrio detrimentoso para os administrados e reconhecido, também, que as normas que a enclausuram propõem-se a defender interesses cuja titularidade última reside nos próprios administrados, estar-se-á apontando um importantíssimo vetor interpretativo que deverá reger a amplitude da investigação dos atos administrativos. ${ }^{279}$

Nas exatas palavras de Celso Antonio BANDEIRA DE MELLO:

"Na verdade, se o objetivo central do Estado de Direito é conferir real proteção aos administrados, efetiva tutela aos seus direitos, e se a maneira indeclinável de assegurá-los implica rigorosa submissão da Administração à lei, em sua letra e seu espírito, não há como recusar ao Poder Judiciário atribuição para diligente investigação e controle dos atos administrativos cuja prática possa ter significado ofensa aos direitos que se querem protegidos." 280

Pode-se, assim, inferir, com esses doutrinadores que a Administração Pública não se sobrepõe ao ordenamento jurídico, ao contrário, a este suas ações estão subsumidas e com este suas ações devem conformar-me em absoluto.

Mais que isso, compreende-se, também, que os atos administrativos ilegítimos, devem ser expurgados do sistema, através da fiscalização a ser empreendida pelo Poder Judiciário. A este cabe zelar pela proteção dos direitos dos administrativos prejudicados pela Administração Pública e servir de contrapeso às arbitrariedades do administrador, esse é, em outra medida, como entendemos, o corolário último do Princípio da Separação de Poderes $^{281}$, uma das bases estruturantes do Estado Moderno.

\footnotetext{
${ }^{278}$ Liberalismo e Democracia. Trad. Brasileira de Marco Aurélio Nogueira. $2^{\text {a }}$ Ed., São Paulo, Brasiliense, 1988 , p. 19.

${ }^{279}$ Cf. Celso Antonio BANDEIRA DE MELLO. Controle Judicial dos Atos Administrativos, p. 66.

${ }^{280}$ Controle Judicial dos Atos Administrativos, p. 66.

281 Para uma visão contemporânea e crítica do Princípio da Separação de Poderes ver Elival da Silva RAMOS. Ativismo Judicial, Parâmetros Dogmáticos, p. 111-120.
} 
Essas noções introdutórias permitem-nos algumas conclusões que, embora básicas, serão de extrema importância mais adiante.

Uma no sentido de que se não há agir administrativo que não esteja subordinado ao ordenamento jurídico, não haveria qualquer esfera de ação da Administração Pública que não pudesse ser confrontada pelos administrados. Os atos administrativos (e regulatórios) poderiam, assim, ser ampla e objetivamente investigados pelo Poder Judiciário.

Outra, considerando o propósito de garantia e proteção dos direitos dos administrados como objetivo fulcral do Estado de Direito, não se poderia negar que não haveria ato administrativo ou parcela de ato administrativo ${ }^{282} q u e$ não pudesse ser escrutinada pelo Poder Judiciário. Essa segunda conclusão encontra, ainda, guarida constitucional, como tratado no item seguinte.

\section{3. A Inafastabilidade do Controle dos Atos Administrativos pelo Poder} Judiciário.

A Constituição Federal em seu art. 5', XXXV, preconiza que "A lei não excluirá da apreciação do Poder Judiciário lesão ou ameaça de direito”. Trata-se da inafastabilidade do controle judicial, alçada à condição de cláusula pétrea, nos termos do art. $60, \S 4^{\circ}$, IV, da Constituição Federal.

A primeira consideração a respeito do dispositivo constitucional é a de que no Brasil vigora o sistema de jurisdição única em que os conflitos em que a Administração Pública é parte compete aos juízes e tribunais ordinários. Assim, são os juízes e tribunais comuns e não especializados em matéria administrativa que exercem o controle jurisdicional da Administração Pública.

Afirma Marcos Paulo VERISSIMO que a constituição de um "Poder Judiciário incumbido de tarefas tão amplas foi considerado, pelo constituinte, como garantia fundamental de preservação do sistema constitucional.” Para o autor o modelo de jurisdição única - "em que as tarefas atribuídas ao Poder Judiciário resultaram de enorme importância, uma vez que lhe foi integre a solução final de controvérsias de

\footnotetext{
${ }^{282}$ Aqui nos referimos ao mérito do ato administrativo, tema que será tratado no item seguinte.
} 
qualquer tipo, inclusive versando atos e interesses do próprio Estado" - representa um (dentre outros) importante mecanismo de controle recíproco do poder em uma sociedade complexa previstos na Constituição Federal de $1988 .^{283}$

Anote-se que a doutrina considera a inafastabilidade do controle dos atos administrativos pelo Poder Judiciário como um princípio $^{284}$ constitucional basilar do Estado de Direito.

Odete MEDAUAR observa a esse respeito que,

$$
\begin{aligned}
& \text { "No tocante ao controle da Administração, o preceito } \\
& \text { afirma a regra da unidade de jurisdição. Assegura a } \\
& \text { proteção judiciária como garantia dos direitos reconhecidos } \\
& \text { pelo ordenamento e como garantia contra a ameaça de } \\
& \text { lesão de direitos. A proteção judiciária representa um dos } \\
& \text { pilares do estado de direito, sobretudo como corolário do } \\
& \text { princípio da legalidade que norteia a atuação dos poderes } \\
& \text { públicos." } 285
\end{aligned}
$$

Outra consideração ainda, acerca do mencionado preceito diz respeito à regra da não exigência de exaustão prévia da via administrativa para que se possa entrar em juízo contra ato da Administração Pública.

A inafastabilidade do controle dos atos administrativos pelo Poder Judiciário é refletida, ainda, na Súmula 473 do Supremo Tribunal Federal (STF), de 03/12/1969, de seguinte teor:

\begin{abstract}
"A administração pode anular seus próprios atos, quando eivados de vícios que os tornam ilegais, porque deles não se originam direitos; ou revogá-los, por motivo de conveniência ou oportunidade, respeitados os direitos adquiridos, e ressalvada, em todos os casos, a apreciação judicial." (grifos nossos)
\end{abstract}

\footnotetext{
${ }^{283}$ Controle Judicial da Atividade Normativa das Agências de Regulação Brasileiras, p. 379-380.

284 A respeito da importância, significado e aplicação dos princípios no Direito ver, por todos, Humberto Ávila. Teoria dos Princípios: da definição à aplicação dos princípios jurídicos.

${ }^{285}$ Direito Administrativo Moderno, p. 392.
} 
Nessa ordem de grandezas, podemos afirmar, sem qualquer dúvida, e em reforço ao quanto asseveramos no item anterior, que não há ato administrativo ou parcela de ato administrativo que não possa ser investigada e confrontada pelo Poder Judiciário.

Apresentadas, desta feita, algumas noções introdutórias sobre Estado de Direito e Inafastabilidade do Controle Judicial dos Atos Administrativos e, bem assim, registradas nossas primeiras e pontuais conclusões, cumpre-nos, então, adentrar as discussões acerca da parcela do ato administrativo que seria isenta de controle pelo Poder Judiciário, ou como a doutrina administrativista denomina, o mérito administrativo.

\section{4. O Mérito do Ato Administrativo.}

O vocábulo mérito pode ser compreendido em duas acepções no Direito Administrativo. Uma atinente à pretensão deduzida no âmbito dos processos administrativos e, outra, referente à esfera nuclear de decisão dos atos administrativos discricionários. É nessa segunda acepção que o estudo do mérito se realiza nesta dissertação.

O conceito de mérito revela-se importante no estudo do controle judicial dos atos administrativos discricionários, na medida em que é utilizado por parte da doutrina administrativista para demarcar um universo intrínseco à capacidade decisória da Administração Pública isento de fiscalização do Poder Judiciário.

Histórica e clássica é a obra de Miguel SEABRA FAGUNDES, O Controle dos Atos Administrativos pelo Poder Judiciário. O autor assim apresenta o seu conceito de mérito do ato administrativo:

"O mérito está no sentido político do ato administrativo. É o sentido dele em função das normas da boa administração, ou noutras palavras, é o seu sentido como procedimento que atende ao interesse público, e, ao mesmo tempo, o ajusta aos interesses privados, que toda medida administrativa tem de levar em conta. Por isso exprime um juízo comparativo. Compreende os aspectos, nem sempre de fácil percepção, atinentes ao acerto, à justiça, utilidade, equidade, razoabilidade, moralidade etc. de cada procedimento 
administrativo. Esses aspectos, muitos autores os resumem no binômio: oportunidade e conveniência." 286

Considera, ainda, o autor que o mérito do ato administrativo constitui aspecto do procedimento da Administração Pública que está relacionado às circunstâncias e apreciações perceptíveis unicamente pelo administrador em razão da função por ele exercida. Ao juiz seria, por conseguinte, vedado adentrar no seu conhecimento; e se o fizesse, exorbitaria o campo da apreciação jurídica (legalidade ou legitimidade), que lhe é reservado como órgão específico de preservação da ordem legal, para incursionar no terreno da gestão política (discricionariedade), própria dos órgãos executivos. ${ }^{287}$

M. SEABRA FAGUNDES deixa claro, seu entendimento no sentido de que o mérito do ato administrativo se circunscreve a um universo inatingível pelo Poder Judiciário e, bem assim, que mérito e legalidade são aspectos opostos do ato administrativo. $^{288}$

O posicionamento de José CRETELLA JÚNIOR acerca do mérito dos atos administrativos é, na mesma medida, importante referência doutrinária no assunto ${ }^{289}$. Ao tratar do conceito de mérito o autor destaca uma série de definições apresentadas pela doutrina italiana ${ }^{290}$, onde sabidamente se desenvolveu com maior impulso esse tema e cuja influência sobre juristas brasileiros foi importante e repercute, ainda, nos dias atuais. ${ }^{291}$

Para o autor, o mérito tal qual para M. SEABRA FAGUNDES é a matiz política do ato administrativo ${ }^{292}$, é a ponderação pessoal da autoridade administrativa; ponderação do oportuno, conveniente, justo, razoável, moral, econômico, equânime, dentre outros fatores de ordem subjetiva, resumidos no binômio oportunidade-

\footnotetext{
286 No mesmo sentido é o entendimento de Diogo de Figueiredo MOREIRA NETO. Legitimidade e Discricionariedade, p. 31.

${ }^{287}$ Cf. Miguel SEABRA FAGUNDES. Conceito de Mérito no Direito Administrativo, p; 1-16.

${ }^{288}$ Conceito de Mérito no Direito Administrativo, p. 1-16.

${ }^{289}$ O Mérito do Ato Administrativo, p. 23-37. E Ato Administrativo - A Tridimensão da Discricionariedade, p. 33-39.

${ }^{290}$ A referência abarca Oreste RANELLETTI, Teoria Degli Atti ammnistrativi Speciali; Lorenzo MEUCCI, Istituzioni di Diritto Amministrativo; Cino VITTA, Diritto Ammnistrativo; Arnaldo de VALLES, Elementi di Diritto Ammnistrativo; Ugo FORTI, Lezioni di Diritto Ammninistrativo; Guido ZANOBINI, Corso di Diritto Ammninistrativo; Massimo Severo GIANNINI, Lezioni di Diritto Ammninistrativo; e Giovanni MIELE, Principii di Diritto Ammnistrativo.

${ }^{291}$ Maria Sylvia Zanella DI PIETRO afirma que não se encontram no Direito Francês ou Alemão referências ao mérito do ato administrativo, não obstante, se fale no princípio da oportunidade e conveniência do administrador. Discricionariedade Administrativa na Constituição de 1988, p. 124.

${ }^{292}$ Tratado de Direito Administrativo, p. 196.
} 
conveniência. ${ }^{293}$ Afirma o jurista, ainda, que o mérito não é e nem pode ser uma visão objetiva do fato, afinal, as autoridades administrativas são pessoas e, como tal, valoram, emitem juízos de valor, ponderam. ${ }^{294}$

Hely Lopes MEIRELLES assinala a presença do mérito administrativo sempre que a Administração Pública decidir ou atuar valorando internamente as conseqüências ou vantagens do ato. ${ }^{295}$

Afirma o autor nesse sentido que,

“O mérito administrativo consubstancia-se, portanto, na valoração dos motivos e na escolha do objeto do ato, feitas pela Administração incumbida de sua prática, quando autorizada a decidir sobre a conveniência, oportunidade $e$ justiça do ato a realizar.” 296

Hely Lopes MEIRELLES com propriedade sintetiza o entendimento da doutrina no sentido de que nos atos vinculados ${ }^{297}$, onde não há faculdade de opção do administrador, unicamente a possibilidade de verificação dos pressupostos de fato e de direito que condicionam o processo administrativo, não há que se falar em mérito, haja vista que toda a atuação da Administração Pública nesse caso se resumiria ao atendimento das imposições legais. ${ }^{298}$

Renato ALESSI apresenta um conceito duplo de mérito do ato administrativo bastante mencionado na doutrina que estuda o tema. ${ }^{299}$ Conforme o jurista italiano, o conceito de mérito pode ser considerado sob dois aspectos, positivo e negativo. $\mathrm{O}$ aspecto negativo seria precisamente a limitação de cognição do Poder Judiciário para além da mera legitimidade (em sentido estrito) do ato administrativo. O aspecto positivo, por sua vez, seria a possibilidade de aferição pelo Poder Judiciário de correspondência do ato administrativo à norma jurídica, segundo critérios de efetiva oportunidade e conveniência.

\footnotetext{
293 O Mérito do Ato Administrativo, p. 31-32.

${ }^{294}$ O Mérito do Ato Administrativo, p. 32.

${ }^{295}$ Cf. Direito Administrativo Brasileiro, p. 146.

${ }^{296}$ Hely Lopes MEIRELLES, Direito Administrativo Brasileiro, p. 146-147.

297 A essa altura, não iremos nos alongar no tema dos atos administrativos vinculados, uma vez que reputamos já ter abordado o tema, no que é relevante para esta dissertação, em nosso Capítulo I.

${ }^{298}$ Direito Administrativo Brasileiro, p. 147.

${ }^{299}$ Diritto Amministrativo, p.135-136.
} 
Maria Sylvia Zanella DI PIETRO, à esteira de M. SEABRA FAGUNDES, pondera, por sua vez, que o mérito do ato administrativo discricionário diz respeito a sua conveniência, utilidade, adequação aos fins de interesse público, gerais e especiais que se pretendem alcançar com a prática do ato. ${ }^{300}$

Odete MEDAUAR assim bem sintetiza a relação entre poder discricionário e mérito administrativo:

\begin{abstract}
"A margem livre sobre a qual incide a escolha inerente à discricionariedade corresponde à noção de mérito administrativo. $O$ mérito administrativo expressa o juízo de conveniência e oportunidade da escolha no atendimento do interesse público, juízo esse efetuado pela autoridade à qual se conferiu o poder discricionário." 301
\end{abstract}

Marçal JUSTEN FILHO define, por fim, o mérito do ato administrativo como o núcleo de natureza decisória, produzido por uma escolha de vontade pessoal do agente estatal em virtude de uma autorização legislativa. ${ }^{302}$

Em comum todas essas definições apresentam a delimitação de uma esfera exclusiva de decisão discricionária da Administração Pública isenta ao controle judicial, ainda que, por vezes, alguns doutrinadores dessa linha de entendimento, esforcem-se para reduzir ao máximo o conteúdo do mérito do ato administrativo, alargando, por conseguinte, o âmbito da sua legalidade e, pois, ampliando a parcela sindicável do ato administrativo pelo Poder Judiciário.

Não concordamos com essa vertente doutrinária. Parece-nos que sob a alcunha de mérito do ato administrativo quer-se proteger pretensa vontade decisória da autoridade pública que, a nosso ver, inexiste. Acreditamos que não há lugar para avaliações subjetivas nos atos administrativos discricionários.

Entendemos, como já tivemos a oportunidade de registrar no Capítulo II, que o exercício da atividade pública constitui função estatal, isto é, um poder de agir traduzido

\footnotetext{
${ }^{300}$ Discricionariedade Administrativa na Constituição de 1988, p. 124-125.

${ }^{301}$ Direito Administrativo Moderno, p. 110.

${ }^{302}$ Curso de Direito Administrativo, p. 992.
} 
em verdadeiro dever e legitimado estritamente com o atingimento da finalidade predicada em lei ${ }^{303}$ e não com a tradução da vontade pessoal ou política do agente estatal.

Assim, conquanto dever-poder ${ }^{304}$ o agir administrativo, ainda que discricionário é absolutamente controlável pelo Poder Judiciário e deve refletir, com objetividade, as razões e os parâmetros de ponderação utilizados pela autoridade em seu processo decisório, ainda que, no seu exercício, noções subjetivas do agente possam influenciar a escolha pública.

De todo modo, os efeitos da demarcação do mérito do ato administrativo conquanto universo isento de controle judicial serão tratados adiante. Antes, porém, iremos apresentar, de maneira breve, a relação entre mérito e legalidade do ato administrativo, tal como tratada na doutrina administrativista pátria.

\section{IV.4.1. Mérito versus Legalidade dos Atos Administrativos Discricionários.}

Menciona-se classicamente que ao Poder Judiciário descaberia o exame de mérito dos atos administrativos, cabendo-lhe tão-somente a aferição da legalidade do ato administrativo, isto é, a verificação de que estes se encontram de acordo com os requisitos legais.

Originalmente, os bordes da legalidade alcançavam apenas os aspectos formais do ato administrativo; todavia, gradativamente, os desbordou para abranger, além destes, o motivo e a finalidade do ato administrativo; permitindo-se, assim, o controle judicial também sobre esses aspectos dos atos administrativos, razão pela qual Odete MEDAUAR afirma que, contemporaneamente, se aponta tendência a considerar que o contraponto legalidade-mérito encontra-se atenuado. ${ }^{305}$

Como vimos no item anterior, M. SEABRA FAGUNDES considera que mérito e legalidade são aspectos antagônicos do ato administrativo.

\footnotetext{
${ }^{303}$ Cf. Carlos Ari SUNDFELD. Fundamentos de Direito Público, p. 163 e ss.

304 Celso Antonio BANDEIRA DE MELLO bem explica que "a idéia de dever é que é predominante, enquanto a idéia de poder vem marcada por um destino ancilar, já que os poderes são conferidos como simples instrumentos necessários ao cumprimento dos deveres." E conclui o autor: "Portanto, são deverespoderes, antes que poderes-deveres.”. Controle Judicial dos Atos Administrativos, p. 31.

${ }^{305}$ Direito Administrativo Moderno, p. 148.
} 
A esse respeito o jurista apresenta sua contrariedade aos posicionamentos de Vitor Nunes LEAL e Castro NUNES, que se ocuparam do tema, mas negaram a oposição entre mérito e legalidade do ato administrativo. Ambos opinaram que o mérito do ato administrativo poderia situar-se como uma questão de ordem legal.

M. SEABRA FAGUNDES discorda e afirma que os domínios do merecimento e da ordem legal não se confundem, ao contrário, é uma imposição decorrente da divisão de funções da vida estatal e das peculiaridades próprias de cada uma delas. ${ }^{306}$

José CRETELLA JÚNIOR, por sua vez, sustenta que mérito e legalidade apresentam contornos especialíssimos, porque não se identificam, nem se repelem, como antitéticos, pois, designam campos diferentes, situados em planos distintos, mas não opostos. Afirma, ainda, o autor que se alguma coincidência entre mérito e legalidade existisse ambos perderiam sua razão de ser ou a noção de legalidade, sobrepujaria a noção de mérito. ${ }^{307}$

De maneira geral, a doutrina relaciona o mérito do ato administrativo com a discricionariedade da Administração Pública ou, em outras palavras, valendo-nos do conceito de mérito apresentado no item anterior, o mérito conquanto margem de conveniência e oportunidade decisória do agente contrapor-se-ia à subsunção dos demais aspectos do ato administrativo (tudo que não fosse conveniência e oportunidade da autoridade pública) ao ordenamento jurídico.

Essa contraposição de mérito e legalidade demarcaria, também, a distinção entre atos administrativos discricionários e vinculados, tema já tratado no Capítulo I da dissertação.

Maria Sylvia Zanella DI PIETRO ressalva, entretanto, que nem todos os juristas italianos concordam com a identificação entre mérito do ato administrativo e discricionariedade. ${ }^{308}$

AMORTH, citado a título exemplificativo pela autora, demonstra que não há necessariamente correspondência entre as noções de discricionariedade e mérito do ato administrativo. Para o jurista italiano, a legalidade pode ser absoluta - quando o direito

\footnotetext{
${ }^{306}$ Conceito de Mérito no Direito Administrativo, p. 1-16.

${ }^{307}$ O Mérito do Ato Administrativo, p. 29 e 36.

${ }^{308}$ Discricionariedade Administrativa na Constituição de 1988, p. 125.
} 
regula completamente o conteúdo da atividade administrativa - ou relativa - quando a regulamentação é imprecisa e a atividade administrativa é livre para agir segundo critérios de apreciação, que podem ser técnicos, políticos, de boa administração ou jurídicos. Porém,ainda nesse segundo caso, em que se localizaria a discricionariedade administrativa, o direito interviria como limite finalístico.

De nossa parte, entendemos que não há oposição entre mérito e legalidade simplesmente pelo fato de que não reconhecemos existir um universo denominado mérito, constituído pela vontade subjetiva da autoridade pública, traduzida no binômio conveniência-oportunidade. Se não há tal universo não há nada que se opor a ele.

Interessante notar, ainda, o esvaziamento do conteúdo do mérito do ato administrativo e a movimentação do que se afirmava constituir o seu teor para o âmbito da legalidade. Tal constatação é claramente percebida com a admissão da confrontação dos motivos e da finalidade do ato administração pelo Poder Judiciário, sob a justificativa de que se trataria meramente de exame de legalidade e não de mérito.

Expostos a noção de mérito do ato administrativo e seu relacionamento com a legalidade, importa analisar especificamente o controle judicial dos atos administrativos.

\section{5. O Controle Judicial dos Atos Administrativos.}

A doutrina acerca do controle judicial dos atos administrativos ${ }^{309}$ surgiu com vistas a demarcar os contornos da fronteira entre o exercício da discricionariedade pela Administração Pública e o seu controle desempenhado pelo Poder Judiciário. ${ }^{310}$

A problemática relativa ao tema diz respeito especialmente ao controle judicial dos atos administrativos discricionários, principal universo do desvio de poder e da captura do regulador, uma vez que com relação ao controle dos atos administrativos vinculados não há dúvidas de que seu alcance está estritamente na lei, embora se reconheça que esses também possam ser arbitrários. ${ }^{311}$

\footnotetext{
309 Para uma rápida visão da evolução do tema ver Marcos Paulo VERISSIMO. Controle Judicial da Atividade Normativa das Agências de Regulação Brasileiras, p. 383-386.

310 Celso Antonio BANDEIRA DE MELLO coloca o controle judicial dos atos administrativos como um princípio constitucional. Curso de Direito Administrativo, p. 120-121.

${ }^{311}$ Cf. Carmen CHINCHILLA MARIN. La Desviacion de Poder, p. 57 e ss.
} 
As preocupações sobre o tema podem ser resumidas nos seguintes questionamentos:

- Quais são a amplitude e o alcance do controle judicial sobre os atos administrativos discricionários?

- O Poder Judiciário pode substituir a decisão administrativa discricionária emanada pela autoridade pública?

Não é nosso intuito esgotar o tema do controle judicial dos atos administrativos, mas, tão-somente, apresentar as discussões acerca da extensão da investigação judicial nos casos em que a Administração Pública atua discricionariamente.

Com efeito, inúmeros estudos jurídicos, nacionais e estrangeiros, tratam dos limites de atuação do Poder Judiciário para controlar os atos administrativos discricionários.

De um lado sustenta-se a atuação comedida e restrita à legalidade do Poder Judiciário na revisão dos atos administrativos e, de outro lado, defende-se uma maior amplitude do controle (por vezes, referido como sindicância pela doutrina) dos atos administrativos discricionários pelo Poder Judiciário.

A primeira vertente doutrinária, majoritária, posiciona-se no sentido de que seria possível o controle judicial dos atos administrativos exclusivamente quanto aos seus aspectos de legalidade. A legalidade, para essa vertente, de maneira geral, seria todo $o$ universo não contemplado pela conveniência e oportunidade da Administração Pública. ${ }^{312}$

312 Algumas teorias para estabelecer limites ao exercício do poder discricionário, com vistas a ampliar a
possibilidade de sua apreciação pelo Poder Judiciário foram desenvolvidas. Uma foi a Teoria do Desvio de
Poder cujo fundamento é a utilização do poder discricionário pela autoridade para fim diverso daquele fixado
em lei, como vimos em nosso Capítulo II. De acordo com Odete MEDAUAR a Teoria do Desvio de Poder
"representou importante passo no sentido de direcionar o exercício do poder discricionário aos fins de
interesse público, explícitos ou implícitos, em razão dos quais esse poder foi conferido ao agente
administrativo. Os poderes atribuídos aos agentes visam ao atendimento do interesse público pertinente à
matéria em que esses agentes atuam. Não se destinam tais poderes à satisfação de interesses pessoais, de
grupos, de partidos, nem são instrumentos de represália, vingança ou favorecimento próprio ou alheio."
Direito Administrativo Moderno, p. 151. Maria Sylvia Zanella DI PIETRO, por sua vez, assevera que em
ocorrendo a comprovação do desvio de poder, estaria o Poder Judiciário autorizado a decretar a nulidade do
ato, uma vez que a Administração Pública teria desviando-se dos "fins de interesse público definidos na lei".
Direito Administrativo, p. 207 . Outra foi a Teoria dos Motivos Determinantes cuja base é a vinculação da
validade do ato administrativo aos motivos indicados pelo administrador público como seu fundamento. Em
se verificando a ocorrência de vícios nos motivos da decisão administrativa discricionária, essa poderia ser 
M. SEABRA FAGUNDES ao sintetizar seu entendimento acerca do controle judicial dos atos administrativos discricionários afirma:

\begin{abstract}
"Este [o controle jurisdicional] é pleno em se tratando de atos praticados no exercício de competência estrita $e$ limitado quando se trata de atos de sentido discricionário. Nos primeiros, só havendo a examinar aspectos de legalidade, nada escapa à revisão judicial. Nos segundo, existindo, ao lado dos aspectos legais, aspectos de mérito (os concernentes ao motivo e ao objeto), a autoridade judiciária não lhes devassa todo o conteúdo. Distingue entre o que constitui merecimento e legalidade para somente pronunciar-se quanto aos aspectos legais., 313
\end{abstract}

Caio TÁCITO registrou que ao Poder Judiciário caberia examinar não somente o arcabouço de condições externas de legalidade do ato administrativo (competência, forma, existência material dos motivos), como também as condições internas da legalidade (finalidade). Segundo o autor, a matéria de fato a que se relaciona o agir administrativo não teria seu acesso vedado ao Poder Judiciário. Conclusão no sentido de óbice ao Poder Judiciário nesse sentido decorreria de uma falta concepção de mérito. A verificação da existência dos motivos e a comprovação da finalidade da decisão administrativa seriam, pois, de substancial importância para o controle da Administração Público. Contudo, não transpassariam a fronteira do exame de legalidade. ${ }^{314}$

Vítor NUNES LEAL posiciona-se no mesmo sentido de Caio TÁCITO, porém, denomina diferentemente os grupos de elementos dos atos administrativos à disposição do

anulada pelo Poder Judiciário. "A teoria dos motivos determinantes é consagrada pelo Supremo Tribunal Federal ao proclamar que 'é pacífico o entendimento de que a apreciação pelo Judiciário dos pressupostos ou motivos determinantes de um ato administrativo vinculado, como ocorre na espécie, não importa invasão do juízo discricionário do Poder Executivo, no apreciar o mérito, senão o exato controle da legalidade do ato', uma vez que, como acentua o Supremo Tribunal de Justiça, 'o controle jurisdicional do ato administrativo, para não violar a separação dos poderes, distancia-se do critério político (mérito), cingindose à verificação das prescrições legais determinadas (competência e manifestação da vontade do agente, objeto, conteúdo, finalidade e forma)', concluindo que, 'desde que lícitos', o critério político e razões técnicas são estranhos à prestação jurisdicional, desde que a opção política esteja em conformidade com o Direito." Cf. Alexandre de MORAES, Princípio da Eficiência e Controle Jurisdicional dos Atos Administrativos Discricionários, p. 18. Sobre a Teoria dos Motivos Determinantes conferir: Direito Administrativo, Maria Sylvia Zanella DI PIETRO; Direito Administrativo Brasileiro, Hely Lopes MEIRELLES; Curso de Direito Administrativo, Celso Antônio BANDEIRA DE MELLO. E O Princípio da Moralidade no Direito Público, Celso Ribeiro BASTOS, p. 66 e ss.

${ }^{313}$ Conceito de Mérito no Direito Administrativo, p; 10.

${ }^{314}$ Temas de Direito Público (Estudos e pareceres), p. 315 e ss. 
controle de legalidade pelo Poder Judiciário. Às condições internas de legalidade do ato administrativo (de Caio Tácito), o autor denomina de limites verticais e às condições externas o jurista denomina de limites horizontais. ${ }^{315}$

Com efeito, Odete MEDAUAR anota que durante a vigência da Constituição Federal de 1946, foram marcantes os posicionamentos de M. SEABRA FAGUNDES, Vitor Nunes LEAL e Caio TÁCITO para a ampliação do controle judicial dos atos administrativos para além da competência e formado ato administrativo, aos motivos e fins como integrantes da legalidade e não da discricionariedade e mérito do ato administrativo. $^{316}$

José CRETELLA JÚNIOR, por sua vez, entende que nenhum aspecto do mérito do ato administrativo admite revisão pelo Poder Judiciário, porque este não invade terreno privativo da Administração Pública. ${ }^{317}$ Para o autor ao "Poder Judiciário é facultado o exame do mérito do processo administrativo, investigando se houve fato, fiscalizando as provas através de reexame, indo aos motivos, observando se houve a aplicação falsa, viciosa ou errônea da lei ou regulamento. Tudo isso é exame da legalidade, porque o mérito do ato administrativo continua a ser campo privativo da Administração, impenetrável ao Judiciário.” 318

Hely Lopes MEIRELLES assevera que no caso dos atos administrativos discricionários, em que a lei confia à Administração Pública a escolha e a valoração dos motivos e do objeto, não caberia ao Poder Judiciário rever os critérios adotados pelo administrador, uma vez que não existiriam padrões de legalidade para aferir essa atuação. $^{319}$

O autor explica que o controle de legalidade ou legitimidade é o que objetiva verificar unicamente a conformação do ato ou do procedimento administrativo com as normas legais que o rege. E o controle de mérito é aquele que visa à comprovação da eficiência, do resultado, da conveniência ou oportunidade do ato controlado. Para Hely Lopes MEIRELLES a conveniência e oportunidade do ato administrativo estão atreladas a

\footnotetext{
${ }^{315}$ Problemas de Direito Público e outros Problemas, p. 256 e ss.

${ }^{316}$ Direito Administrativo Moderno, p. 395.

${ }^{317}$ O Mérito do Ato Administrativo, p. 25-36.

${ }^{318}$ O Mérito do Ato Administrativo, p. 37.

${ }^{319}$ Direito Administrativo Brasileiro, p.147.
} 
critérios político-administrativos e discricionários, razão pela qual o controle de eficiência e resultado não pode ser exercido pelo Poder Judiciário. ${ }^{320}$

Diogo de Figueiredo MOREIRA NETO, autor de importante e específica obra sobre o tema, "Legitimidade e Discricionariedade: Novas Reflexões sobre os Limites e Controle da Discricionariedade”, considera que o núcleo de escolhas administrativas continua insindicável, porém, os seus limites podem e devem ser controlados pelo Poder Judiciário. $^{321}$

Afirma o jurista que a oportunidade e a conveniência do ato administrativo discricionário devem ser examinadas sempre que se pretenda verificar a sua conformidade ou desconformidade à ordem jurídica. E nesse mister, o Poder Judiciário deteria legitimidade indireta ${ }^{322}$, a partir da definição positivada de legitimidade que se contém na norma legal, explícita ou implicitamente quando autoriza à Administração o exercício da discricionariedade. ${ }^{323}$

Diogo de Figueiredo MOREIRA NETO preconiza, pois, o controle dos atos administrativos discricionários por meio de limites instrumentais - o da realidade e o da razoabilidade - aplicados com lógica e objetividade em uma razão do todo para a parte em busca do respeito ou da exorbitância dos limites à discricionariedade. ${ }^{324}$

Nesse sentido o jurista assenta que o controle não se dá sobre o mérito em si, mas sobre o que exorbite de limites lógico-jurídicos e, portanto, sujeitos a avaliação de racionalidade e razoabilidade. Explica o autor que o que se sujeita à apreciação do Poder Judiciário não é a discricionariedade da autoridade administrativa em si, mas o resultado de seu exercício e, ainda assim, no que exorbitou dos limites da ordem jurídica. ${ }^{325}$

Assim, o Poder Judiciário poderia anular os atos administrativos discricionários fundados em inexistência de motivo, insuficiência de motivo, inadequabilidade de motivo, incompatibilidade de motivo, desproporcionalidade de motivo, impossibilidade de objeto,

\footnotetext{
${ }^{320}$ Direito Administrativo Brasileiro, p. 627-628.

${ }^{321}$ Legitimidade e Discricionariedade, p. 57 e ss.

322 Segundo o autor a legitimidade direta seria do povo e de seus representantes eleitos no Estado Democrático. Legitimidade e Discricionariedade, p. 60.

${ }^{323}$ Legitimidade e Discricionariedade, p. 60.

${ }^{324}$ Legitimidade e Discricionariedade, p. 61.

${ }^{325}$ Legitimidade e Discricionariedade, p. 58-60.
} 
desconformidade de objeto e ineficiência de objeto. ${ }^{326} \mathrm{O}$ que se defere ao Poder Judiciário, portanto, é o controle de legalidade. ${ }^{327}$

Maria Sylvia Zanella DI PIETRO bem sintetiza o pensamento da vertente doutrinária que identifica na lei (legalidade) o limite absoluto e único à discricionariedade administrativa e, por conseguinte, a impossibilidade de sua apreciação pelo Poder Judiciário. ${ }^{328}$ A autora afirma, nesse sentido, que

"A rigor, pode-se dizer que, com relação ao ato discricionário, o Judiciário pode apreciar os aspectos da legalidade e verificar se a Administração não ultrapassou os limites da discricionariedade. Por isso mesmo, seria lícito dizer que a legalidade constitui o limite único à discricionariedade administrativa." 329

Explica Maria Sylvia Zanella DI PIETRO que tal afirmação é conseqüência do fato de que a discricionariedade é um poder delimitado previamente pelo legislador que, intencionalmente, deixa um espaço para livre decisão da Administração Pública, legitimando previamente sua opção; de modo que, qualquer que seja a sua opção, seria legal. Por essa razão - de prévia legitimação legal da escolha discricionária - o Poder Judiciário não poderia rever a opção elegida pela Administração Pública no exercício de seu Poder Discricionário. Caso contrário, o Poder Judiciário poderia substituir, por seus próprios critérios de escolha, a opção legítima realizada pela autoridade competente com base em razões de conveniência e oportunidade que a ela cumpria sopesar. ${ }^{330}$ Ao tema da substitutividade das decisões administrativas discricionárias pelo Poder Judiciário voltaremos mais adiante.

Ampliados, assim, por um lado, os limites da legalidade para abranger também os motivos e a finalidade dos atos administrativos discricionários ${ }^{331}$, expandiram-se, ainda,

\footnotetext{
${ }^{326}$ Legitimidade e Discricionariedade, p. 62.

327 José CRETELLA JÚNIOR explicitou que mérito não é motivo. Motivos seriam as razões de fato e de direito que fundamentariam a decisão da autoridade administrativa. Terreno da legalidade. O Mérito do Ato Administrativo, p. 31-35.

${ }^{328}$ Discricionariedade Administrativa na Constituição de 1988, p. 133 e ss.

${ }^{329}$ Discricionariedade Administrativa na Constituição de 1988, p. 133.

${ }^{330}$ Discricionariedade Administrativa na Constituição de 1988, p. 133.

${ }^{331}$ Segundo Maria Sylvia Zanella DI PIETRO a tendência por ampliação do controle dos atos administrativos discricionários se verificou em razão do aumento das noções imprecisas que o legislador se utiliza frequientemente para designar o motivo e a finalidade do ato administrativo como, por exemplo, interesse público, conveniência administrativa, moralidade e ordem pública. Direito Administrativo, p. 207.
} 
por outro lado, as bases de confrontação dessa legalidade, ao que se denominou como vimos no Capítulo I, de juridicidade. De modo que, os elementos dos atos administrativos discricionários passariam a ser controlados não só com base nas leis e na Constituição Federal, mas também passariam a ser limitados por uma série de princípios gerais do direito que se constituiriam em novas referências para o controle judicial dos atos administrativos discricionários.

Odete MEDAUAR ressalta, por sua vez, que a tendência de ampliação do controle judicial da Administração Pública por meio dos princípios gerais do direito ${ }^{332}$ se acentuou a partir da Constituição Federal de 1988.

Segundo a autora:

"o texto de 1988 está impregnado de um espírito geral de priorização dos direitos e garantias ante o poder público. Uma das decorrências desse espírito vislumbra-se na indicação de mais parâmetros de atuação, mesmo discricionária, da Administração, tais como o princípio da moralidade e o princípio da impessoalidade. O princípio da publicidade, por sua vez, impõe transparência na atuação administrativa, o que enseja maior controle." 333

A esse respeito, Maria Sylvia Zanella DI PIETRO assevera que, embora no Brasil não haja tradição de criação do direito administrativo nos tribunais, é possível que o Poder Judiciário aprecie os atos discricionários da Administração Pública por meio da aplicação dos princípios gerais do direito, sempre que essa possua várias opções para atingir a mesma finalidade. ${ }^{334}$

Explica a autora que os princípios gerais do direito são de observância obrigatória pela Administração Pública, quer tenham origem constitucional (implícita ou explicitamente), legal ou na teoria geral do direito e são prestantes a limitar a reduzir a

\footnotetext{
${ }^{332}$ Garcia de ENTERRÍA e Tomas- Ramón FERNÁNDEZ afirmam que os princípios gerais do direito não se constituem em um abstrato reclamo da moral ou da justiça, mas em uma condensação de grandes valores jurídicos materiais que constituem o substrato do ordenamento jurídico. Eduardo Garcia de ENTERRÍA e Tomás-Ramon FERNÁNDEZ. Curso de Direito Administrativo, p. 449.

${ }^{333}$ Direito Administrativo Moderno, p. 395.

${ }^{334}$ Discricionariedade Administrativa na Constituição de 1988, p. 171 e ss.
} 
margem de discricionariedade da Administração Pública, estendendo o domínio da competência vinculada e da legalidade. ${ }^{335}$

Conclui a autora, ainda, que:

"Por isso mesmo, em vez de afirmar-se que a discricionariedade é liberdade de ação limitada pela lei, melhor se dirá que a discricionariedade é liberdade de ação limitada pelo Direito. O princípio da legalidade há de ser observado, não no sentido estrito, concebido pelo positivismo jurídico e adotado no chamado Estado legal, mas no sentido amplo que abrange os princípios que estão na base do sistema jurídico vigente, e que permitem falar em Estado de Direito propriamente dito."

Celso Antonio BANDEIRA DE MELLO posiciona-se no sentido de que a revisão dos atos administrativos pelo Poder Judiciário é um dever indeclinável e meio específico e próprio para assegurar o Estado de Direito. O autor afirma, ainda, que este exame é tanto mais necessário quando se sabe que os riscos para os direitos e garantias individuais avultam nos casos em que a Administração Pública desfruta de certa discricionariedade. E defende no cotejo do ato administrativo discricionário pelo Poder Judiciário especialmente a utilização do princípio da razoabilidade. ${ }^{336}$ Não obstante, tais assertivas, com as quais concordamos plenamente, o autor considera que:

\begin{abstract}
"O campo de apreciação meramente subjetiva - seja por conter-se no interior das significações efetivamente possíveis de um conceito legal fruído e impreciso, seja por dizer com a simples conveniência ou oportunidade de um ato - permanece exclusivo do administrador e indevassável pelo juiz, sem o que haveria substituição de um pelo outro, a dizer, invasão de funções que se poria às testilhas com o próprio princípio da independência dos Poderes, consagrado no ar. $2^{\circ}$ da Lei Maior.” 337
\end{abstract}

\footnotetext{
${ }^{335}$ Discricionariedade Administrativa na Constituição de 1988, p. 171 e ss.

${ }^{336}$ Curso de Direito Administrativo, p. 948 e ss. No mesmo sentido é o entendimento de Marçal JUSTEN FILHO com pequena variação para a aplicação do princípio da proporcionalidade. Curso de Direito Administrativo, p. 992.

${ }^{337}$ Curso de Direito Administrativo, p. 982.
} 
Em outras palavras, o autor reconhece, tal como os demais doutrinadores dessa vertente, a existência de uma esfera do ato administrativo discricionário, de ordem subjetiva do agente estatal, intocável pelo poder judiciário.

Não obstante, o jurista esvazia em grande medida o teor do que entende por mérito do ato administrativo e, portanto, o universo insindicável dos atos administrativos. ${ }^{338}$ Celso Antonio BANDEIRA DE MELLO, traçando o conjunto de situações que importam em desvio de poder da autoridade pública, afirma que:

"extrapolam o mérito e maculam o ato de ilegitimidade os critérios que o agente adote para decidir-se que não tenham sido idoneamente orientados para atingir o fim legal. É o que se passa naqueles: (a) contaminados por intuitos pessoais - pois a lei está a serviço da coletividade e não do agente; (b) correspondentes a outra regra de competência, distinta da exercitada - pois à lei não são indiferentes os meios utilizados; (c) que revelam opção desarrazoada - pois a lei não confere liberdade para providências absurdas; (d) que exprimem medidas incoerentes: 1.com os fatos sobre os quais o agente deveria exercitar seu juízo; 2. com as premissas que o ato deu por estabelecidas; 3. com decisões tomadas em casos idênticos, contemporâneos ou sucessivos - pois a lei não sufraga ilogismos, nem perseguições, favoritismos, discriminações gratuitas à face da lei, nem soluções aleatórias; (e) que incidem em desproporcionalidade do ato em relação aos fatos - pois a lei não endossa medidas que excedem ao necessário para atingimento de seu fim." 339 (grifos nossos)

Em todas essas situações de arbitrariedade da autoridade pública o autor reputa que há ilegalidade (e não mérito do ato administrativo) e, pois, o Poder Judiciário deveria fulminar atos dessa espécie.

Marçal JUSTEN FILHO sustenta que não se admite a revisão pelo Poder Judiciário do juízo de conveniência e oportunidade realizado pela Administração Pública.

\footnotetext{
${ }^{338}$ Essa mesma ação (de esvaziamento do mérito do ato administrativo) é realizada por outros autores desta mesma linha doutrinária.

${ }_{339}^{33}$ Discricionariedade e Controle Jurisdicional, p. 82-83.
} 
Mas pondera que isso não impede a invalidação de atos administrativos por defeitos formais. Admite, ainda, a aplicação do princípio da proporcionalidade e o reconhecimento de que a decisão administrativa foi defeituosa porquanto inadequada ou desnecessária ao cumprimento da finalidade legal. ${ }^{340}$

Considera o autor que o Poder Judiciário poderá examinar os requisitos externos de regularidade da atuação discricionária, isto é, verificar se os requisitos legais procedimentais foram respeitados e, bem assim, se a autoridade administrativa agiu visando à realização dos direitos fundamentais, com observância dos valores democráticos.

Nesse contexto, passou-se a reconhecer o controle legalidade estendido dos atos administrativos discricionários, isto é, de todos os elementos do ato administrativo, salvo por sua conveniência e oportunidade, através de referências principiológicas que permeiam o ordenamento jurídico, especialmente por meio da aplicação dos princípios da razoabilidade e da proporcionalidade. ${ }^{341}$

Malgrado sejam respeitáveis os posicionamentos apresentados, a nosso ver há certa incoerência dessa vertente doutrinária. Isso porque, nota-se a tentativa de esvaziamento do conteúdo do mérito do ato administrativo, transladando-se o seu teor à esfera da legalidade, sobre a qual se preconiza a aplicação dos princípios gerais do direito para o controle da decisão administrativa discricionária no caso concreto. Preserva-se, intacto e intocável, ainda que esvaziado, o mérito do ato administrativo, ou, a conveniência e oportunidade da autoridade administrativa, embora não se precise exatamente o que com isso se quer dizer.

Parece-nos que sustentar a existência de parcela do ato administrativo incólume ao controle judicial, consistente em alguma nebulosa valoração subjetiva do agente estatal, é afrontoso ao próprio Estado de Direito e seus fundamentos; além de fazer letra morta do art. $5^{\circ}, \mathrm{XXXV}$ da Constituição Federal, uma vez que abriria a possibilidade de que sob o

\footnotetext{
${ }^{340}$ Curso de Direito Administrativo, p. 992 e ss.

${ }^{341}$ Tal como Odete Medauar, Maria Sylvia Zanella di Pietro, Marçal Justen Filho e Celso Antonio Bandeira de Mello, por exemplo. Outros tantos doutrinadores como Floriano de Azevedo Marques Neto, Sérgio Guerra, Gustavo Binembojm, Jessé Torres Pereira Junior e Alexandre Santos do Aragão, dentre outros, da mesma forma reconhecem o controle dos atos administrativos por meio de princípios gerais de direito, contudo, não restringem esse controle exclusivamente ao âmbito da legalidade do ato administrativo discricionário.
} 
argumento de se tratar de questão de conveniência e oportunidade da Administração Pública, a autoridade poderia violar, sem remédio algum, os direitos dos administrados.

Ademais, entendemos que o cotejo da legalidade do ato administrativo discricionário, especialmente dos seus motivos e finalidade, por meio da aplicação dos princípios gerais de direito, tais como a razoabilidade e a proporcionalidade, importam em alguma medida, na análise dos aspectos subjetivos que serviram de móvel para a tomada da decisão pela autoridade administrativa. Essa avaliação, a nosso ver, abrangeria também, direta ou indiretamente, o exame de conveniência e oportunidade do ato administrativo discricionário, o que faria, portanto, ser sem sentido a defesa pela preservação da incolumidade do mérito administrativo.

Por fim, não vemos no controle do mérito do ato administrativo discricionário violação ao Princípio da Separação de Poderes, mas sua reafirmação.

Em suma, os posicionamentos doutrinários como os reportados acima refletem o anseio dos autores por admitir um maior controle das decisões administrativas discricionárias e evitar o arbítrio do agente estatal, mas, ainda, demonstram existir certa resistência em romper com as restrições de amplo controle dos atos administrativos discricionários da Administração Pública.

Pois bem. A segunda vertente doutrinária, a que aludimos inicialmente, minoritária, posiciona-se no sentido de que seria possível o controle judicial dos atos administrativos sem reservas ao mérito do ato administrativo.

Essa linha da doutrina administrativista reconhece a diluição da dicotomia legalidade-mérito ${ }^{342}$ conquanto resultado do agigantamento do Direito e da introdução do discurso jurídico de princípios ${ }^{343} \mathrm{em}$ seu cerne, agregando-lhe razões de ordem multidisciplinar, notadamente econômicas, políticas, morais e de gestão empresarial.

De acordo com esses doutrinadores essa nova configuração do universo jurídico seria, em verdade, reflexo da nova configuração da sociedade contemporânea, reconhecidamente mais complexa, aliada aos novos imperativos políticos e econômicos do

\footnotetext{
${ }^{342}$ Cf. Giuseppe DI GASPARE. Il Potere nel Diritto Pubblico, p. 418-422. A respeito do discurso jurídico dos princípios ver Carlos Ari SUNDFELD. O Direito Administrativo entre os Clips e os Negócios, p.88.

${ }^{343}$ A respeito do discurso jurídico dos princípios ver Carlos Ari SUNDFELD. O Direito Administrativo entre os Clips e os Negócios, p.88.
} 
Estado Pós-Moderno ${ }^{344} \mathrm{e}$ às novas atribuições estatais, marcadamente de regulação da economia e de mediação de interesses multifacetários legítimos.

Odete MEDAUAR bem apreende as implicações do cenário de moderna regulação e a relevância de se tornar controlável:

“A realidade atual retrata a existência de inúmeros centros públicos titulares de poderes e a ampliação de direitos dos indivíduos, o que, em síntese, leva à homogeneidade dos interesses e à pressão de indivíduos e grupos sobre a Administração para atendimento de suas reivindicações. Também se registram progressiva e tecnicização no tratamento dos assuntos a cargo da Administração e a crescente adoção de práticas consensuais, conciliatórias, $e$ não somente decisões unilaterais imperativas. O conjunto desses fatores acarreta a mudança da natureza pura da discricionariedade. Prega-se então a necessidade de nova disciplina para que se torne objetiva, imparcial, controlável." ${ }^{345}$ (grifos nossos)

Essa nova ordem de fatores implicaria em um agir administrativo absolutamente vinculado - ainda que em diferentes gradações - e amplamente controlável pelo Poder Judiciário - o que não significa que essa linha doutrinária admite a substitutividade das decisões discricionárias da Administração Pública pela decisão judicial, ao contrário. Como veremos ao final desse capítulo, ambas as vertentes repudiam a substitutividade da decisão administrativa discricionária, especialmente a regulatória, pela sentença judicial.

Desta feita, o controle dos atos administrativos discricionários não poderia mais ser resolvido simplesmente com a sua classificação em "discricionário" ou

\footnotetext{
${ }^{344}$ Acerca das transformações do Estado e da transição para o denominado Estado Pós-Moderno ver artigo de Diogo de Figueiredo MOREIRA NETO. O Novo Papel do Estado na Economia em que o autor pontua as premissas sobre o Estado em transformação e demarca com precisão os fatores determinantes do Estado PósModerno.

${ }^{345}$ Cf. Odete MEDAUAR. O Direito Administrativo em Evolução, p. 196.
} 
"vinculado", a qual estaria intrínseca a superação da barreira do controle judicial do mérito do ato administrativo discricionário. ${ }^{346}$

É o que Gustavo BINENBOJM traduziu em sua teoria dos diferentes graus de vinculação dos atos administrativos à juridicidade em que explicitou não ser possível, contemporaneamente, fazer distinção entre os atos vinculados e os atos discricionários, haja vista que a discricionariedade não se caracterizaria como uma liberdade decisória externa ao direito, em um campo imune ao controle jurisdicional. Para o autor, ter-se-ia apenas diferentes graus de vinculação dos atos administrativos à juridicidade aos quais corresponderiam, via de regra, uma maior ou menor controlabilidade destes pelo Poder Judiciário. $^{347}$

Colocando a questão em outros termos, com Marcos Paulo VERISSIMO, “ $a$ identificação da discricionariedade como uma total liberdade da Administração Pública para decidir ocorre cada vez em mais raras ocasiões.” Admitir-se a eficácia normativa plena a determinados princípios administrativos e constitucionais possibilitaria que, ao menos abstratamente, "todo e qualquer ato administrativo" comportasse "amplo controle de mérito, eis que estaria, de toda sorte, vinculado à eficácia normativa desses princípios, necessitando, por isso, com esses conformar-se." 348

Nas palavras do autor:

"Se a discricionariedade que não comporta controle é aquela ligada a indiferentes jurídicos e se esses são cada vez mais raros, pois cada vez menos matérias são totalmente indiferentes ao direito, todo ato administrativo haveria de comportar controle integral por parte do órgão judiciário.

Em outras palavras, adotando-se um conceito mais amplo de discricionariedade, adotam-se concomitantemente mecanismos diversos destinados a conter a liberdade de ação do agente público nos limites do direito, ao que equivale, a bem da verdade, dizer que há no caso vinculação

\footnotetext{
${ }^{346}$ Cf. Marcos Paulo VERISSIMO. Controle Judicial da Atividade Normativa das Agências de Regulação Brasileiras, p. 389-392.

${ }^{347}$ No mesmo sentido é o entendimento de Juarez Freitas no seu O Controle dos atos Administrativos e os Princípios Fundamentais.

${ }^{348}$ Marcos Paulo VERISSIMO. Controle Judicial da Atividade Normativa das Agências de Regulação Brasileiras, p. 391.
} 
se for adotado um conceito mais estrito. Nesse sentido, concorre a introdução de diversas idéias no direito administrativo, como as de controle do ato pelo fim, de controle de adequação do motivo, de controle de razoabilidade (devido processo legal substantivo) e, em geral, da subsunção do ato administrativo a princípios gerais do direito." ${ }^{349}$ (grifos nossos)

Juarez FREITAS dedica-se muito oportunamente ao tema em sua obra $O$ Controle dos Atos Administrativos e os Princípios Fundamentais, na qual afirma que hodiernamente não se pode conceder discrição com núcleo juridicamente nãovinculado. ${ }^{350} \mathrm{O}$ autor é, ainda, taxativo ao se manifestar a favor do aprofundamento do controle judicial das decisões administrativas discricionárias:

"Quer dizer, já não se admitem os atos administrativos exclusivamente políticos, uma vez que se vincula o administrador público aos motivos que ofertar, sempre que a tomada da decisão administrativa acarretar reflexos sobre direitos ou interesses. Inaceitável, nessa perspectiva, a tese da insindicabilidade das decisões administrativas, ainda mais que em todas as searas se verificam demasias condenáveis e omissões manifestamente antijurídicas. Daí resulta que a necessária liberdade administrativa carece de contrapeso na verticalização e no aprofundamento da sindicabilidade, voltada ao cumprimento rigoroso dos deveres de defesa e de tempestividade prestação dos direitos fundamentais pela Administração Pública." 351 (grifos nossos)

O autor pondera, não obstante, que o controle judicial aprofundado das decisões discricionárias administrativas não decorre a judicialização invasiva ou a falta de deferência à esfera administrativa. Para o jurista o mérito administrativo pode até não ser, no geral das vezes diretamente controlável, mas o demérito (o excesso arbitrário ou a omissão antijurídica) o será, sempre. Nas palavras de Juarez FREITAS:

\footnotetext{
${ }^{349}$ Marcos Paulo VERISSIMO. Controle Judicial da Atividade Normativa das Agências de Regulação Brasileiras, p. 391.

${ }^{350}$ O Controle dos Atos Administrativos e os Princípios Fundamentais, p. 381.

${ }^{351}$ O Controle dos Atos Administrativos e os Princípios Fundamentais, p. 361.
} 
“O 'mérito' (atinente ao campo dos juízos de conveniência ou oportunidade) não é diretamente controlável, mas o demérito e a antijuridicidade o serão, inescapavelmente. Mais que nunca, a discricionariedade legítima supõe o aprofundamento da sindicabilidade, voltada à afirmação dos direitos fundamentais, notadamente do direito fundamental à boa administração pública." ${ }^{352}$

Jessé Torres PEREIRA JUNIOR, por sua vez, afirma que pode ser indispensável que se controle diretamente o mérito do ato administrativo discricionário. Sustenta o autor que considerando que no controle judicial dos atos administrativos discricionários cabe a verificação da relação de adequação entre os motivos, sua avaliação técnica e os resultados da decisão administrativa discricionária - e, pois, se a verificação dos resultados é objeto de controle judicial - pode ser que seja necessário para a sua confrontação, no caso concreto, que o Poder Judiciário sindique o mérito do ato administrativo, sob pena de emitir juízo precário e inconclusivo. ${ }^{353}$

O autor considera superada a asserção de que o objeto do controle judicial dos atos da Administração Pública se circunscreve ao exame da legalidade dos elementos ou requisitos que lhe integram a estrutura morfológica, com exclusão de qualquer outra ótica. Para o jurista pode ocorrer que o ato seja estruturalmente íntegro, isto é, sem vício de ilegalidade, porém padeça de máculas ruinosas da relação entre o que almeja a Administração Pública e o que é do interesse público. Essa contrafação pode e deve ser também objeto do controle judicial, porque dela dependerá o resultado da ação estatal para efetivar ou não direitos. ${ }^{354}$

Pode-se inferir, com esses doutrinadores, que não há parcela do ato administrativo que não seja controlável. É dizer que o mérito do ato administrativo - ou a conveniência e oportunidade da autoridade pública - é controlável tal qual os demais aspectos do ato administrativo discricionário, na medida em que não há agir administrativo desvinculado do Direito.

\footnotetext{
${ }^{352}$ Discricionariedade Administrativa e o Direito à Boa Administração Pública, p. 48.

${ }^{353} \mathrm{O}$ autor valida, ainda, o mesmo raciocínio para o controle do objeto do ato administrativo quando inserto no círculo de discrição administrativa e da finalidade do ato quando implícita na norma. Jessé Torres PEREIRA JUNIOR. Controle Judicial da Administração Pública: da Legalidade à Lógica do Razoável, p. 55.

${ }^{354}$ Cf. Jessé Torres PEREIRA JUNIOR. Controle Judicial da Administração Pública: da Legalidade à Lógica do Razoável, p. 51-52.
} 
Por óbvio, confrontar as razões de conveniência e oportunidade do agente estatal no exercício de sua discricionariedade decisória pode impor aos interessados e ao Poder Judiciário maiores dificuldades na medida em que se estará aferindo a e adequação das ponderações realizadas pela autoridade pública e, como tal, carregadas de subjetividade. Contudo, embora exista maior dificuldade de controle dos aspectos subjetivos da decisão discricionária, não significa que esses não sejam controláveis. Ao contrário, por possibilitarem a valoração do agente estatal é precisamente nos aspectos de conveniência e oportunidade do ato administrativo discricionário que reside o maior risco de arbitrariedades. E, como a história tem nos demonstrado, é aí que essas, na maioria das vezes, se escondem.

Esse problema apresenta-se precisamente por não existirem parâmetros objetivos de controle do agir discricionário da Administração Pública. Referências objetivas e concretas de controle da decisão administrativa discricionária não só contribuiria para a segurança jurídica e previsibilidade do agir administrativo discricionário, como também inibiria, per se, a prática do arbítrio, haja vista que o abuso da autoridade administrativa poderia ser vislumbrado com precisão e certeza, ensejando sua responsabilização de imediato. Ao tema iremos nos dedicar no capítulo seguinte. Antes, porém, cumpre-nos, ainda, algumas considerações acerca do controle judicial dos atos administrativos discricionários.

O controle judicial dos atos administrativos discricionários coloca-se ainda com maior complexidade quando analisado sob o enfoque das Agências Reguladoras, isto é, quando nos deparamos com as decisões regulatórias discricionárias, concretizadas por meio dos atos regulatórios discricionários. É o que passamos a explicitar no item IV. 5.1.2. Antes, porém, convém enfrentar o tema da substitutividade dos atos administrativos discricionários por decisões judiciais, ao qual já fizemos referência por vezes nesse item da dissertação.

\section{IV.5.1. A Substitutividade das Decisões Administrativas Discricionárias.}

Vimos no item anterior que a preocupação acerca da possibilidade de que a decisão judicial venha a substituir a decisão administrativa discricionária é sempre presente quando se trata do tema do seu controle judicial. 
Nesse ponto, há entendimento majoritário da doutrina administrativista no sentido de que não se deve admitir que o Poder Judiciário, no exercício do controle judicial dos atos administrativos discricionários, substitua a decisão emanada pela Administração Pública. Esse posicionamento é compartilhado tanto por aqueles que defendem um controle judicial moderado e comedido dos atos administrativos discricionários, quanto por aqueles que sustentam um controle judicial aprofundado desses e assenta-se precipuamente no argumento de preservação do cânone da separação $e$ independência dos poderes estatais.

Corrente absolutamente minoritária da doutrina administrativista, entretanto, considera que, estritamente nas situações em que haja uma única solução possível ao caso concreto e, bem assim, que o ordenamento jurídico a pré-estabeleça com inteira precisão, o Poder Judiciário poderia, assim, ditar a decisão ao caso concreto comportável pelo Direito.

A preocupação doutrinária é bem resumida por Sérgio GUERRA, que retomando as lições de Renato ALESSI constantes de nosso item IV. 3. acerca do mérito do ato administrativo, esclarece que o controle judicial dos atos administrativos discricionários pode ser implementada de forma negativa ou de forma positiva. ${ }^{355}$

Sob a forma negativa, o controle judicial da decisão administrativa discricionária limitar-se-ia à invalidação ou anulação do ato exarado pela Administração Pública. ${ }^{356}$ Sob a forma positiva, à invalidação ou anulação do ato administrativo discricionária seguir-se-ia um comando legal que substituiria o ato maculado.

O controle judicial dos atos discricionários sob a forma positiva poderia, ainda, ser identificado com o denominado ativismo judicial. ${ }^{357}$

\footnotetext{
${ }^{355}$ Controle Judicial dos Atos Regulatórios, p. 269.

${ }^{356}$ É o que Juarez Freitas em decorrência do direito fundamental à boa administração pública identificou como o controlador na forma de "administrador negativo", no sentido de "terçar armas contra a discricionariedade exercida fora dos limites ou aquém dos limites. Discricionariedade Administrativa e o Direito Fundamental à Boa Administração Pública, p. 11 e ss.

${ }^{357}$ Elival da Silva RAMOS assevera que não há necessariamente um sentido negativo na expressão ativismo, ao contrário, é elogiado por proporcionar a adaptação do direito diante de novas exigências sociais e de novas pautas axiológicas, em contraposição ao 'passivismo' que conduziria a estratificação dos padrões de conduta normativamente consagrados. Porém, aponta a conotação negativa do fenômeno associado à exacerbação do exercício da função judicante pelo Poder Judiciário. Ativismo Judicial, Parâmetros Dogmáticos, p. 110 e 129. Na Espanha nota-se importante tendência de parte da doutrina ao ativismo judicial. Essa vertente doutrinária é encabeçada por Eduardo García de ENTERRÍA e Tomás-Ramón FERNÁNDEZ, que propugnam pela máxima restrição à discricionariedade administrativa. Ver a esse respeito, dentre outros trabalhos desses autores, o próprio Curso de Direito Administrativo, p. 393.
} 
Elival da Silva RAMOS produziu importante e específica obra a respeito do tema. Explica o autor que ativismo judicial reporta-se a uma disfunção no exercício da função jurisdicional em que o Poder Judiciário extrapola de sua função judicante para invadir seara reservada ao Poder Executivo. ${ }^{358}$

A título exemplificativo cite-se apenas alguns posicionamentos da vertente majoritária da doutrina administrativista que aceita tão-somente a forma negativa de controle judicial das decisões administrativas discricionárias.

Conhecida é a passagem de Miguel SEABRA FAGUNDES em que o jurista potiguar registra, sinteticamente, seu posicionamento a respeito do controle judicial comedido dos atos administrativos, mas que já àquela época alertava sobre as conseqüências da revisão judicial positiva dos atos administrativos discricionários.

"Ao Poder Judiciário é vedado apreciar, no exercício do controle jurisdicional, o mérito dos atos administrativos. Cabe-lhe examiná-lo, tão-somente, sob o prisma da legalidade. Este é o limite do controle, quanto à extensão. $O$ mérito está no sentido do ato administrativo. É o sentido dele em função das normas da boa administração, ou noutras palavras, é o seu sentido como procedimento que atende ao interesse público, e, ao mesmo tempo, o ajusta aos interesses privados, que toda medida administrativa tem de levar em conta. Por isso, exprime um juízo comparativo. Compreende os aspectos, nem sempre de fácil percepção, atinentes ao certo, à justiça, utilidade, equidade, razoabilidade, moralidade etc. de cada procedimento administrativo. (...) O mérito é de atribuição exclusiva do Poder Executivo, e o Poder Judiciário, nele penetrando, faria obra de administrador, violando, dessarte, o princípio de separação e independência dos poderes." 359 (grifos nossos)

\footnotetext{
${ }^{358}$ Ativismo Judicial, Parâmetros Dogmáticos, p. 107 e ss.

${ }^{359}$ Controle dos Atos Administrativos pelo Poder Judiciário, p. 179-181.
} 
Hely Lopes MEIRELLES, da mesma forma, manifestava oportunamente sua preocupação com relação à substituição do critério da Administração Pública para a decisão do mérito administrativo pelo pronunciamento do Poder Judiciário porque isto

$$
\begin{aligned}
& \text { “importaria revisão do mérito administrativo, por uma } \\
& \text { simples mudança de juízo subjetivo - do administrador pelo } \\
& \text { do juiz - sem qualquer fundamento em lei." }{ }^{360}
\end{aligned}
$$

Odete MEDAUAR sustenta que, atualmente, no ordenamento jurídico brasileiro não haveria dúvidas de que a legalidade se assenta em bases mais amplas e, em consequência, haveria respaldo constitucional para um controle jurisdicional mais amplo sobre a atividade da Administração Pública. Contudo, tal ampliação não deveria levar à substituição do administrador pelo juiz. ${ }^{361}$

No mesmo sentido é o posicionamento de Celso Antonio BANDEIRA DE MELLO a respeito da extensão do controle judicial dos atos administrativos. Afirma o autor que de forma alguma a maior amplitude da investigação judicial dos atos administrativos deve levar à substituição do juízo do administrador sobre a oportunidade e conveniência de uma providência pelo Poder Judiciário. ${ }^{362}$

Marçal JUSTEN FILHO aponta que na revisão judicial não caberia a desconstituição do ato sob o argumento de que o controlador teria adotado outra solução se estivesse investido de competência para tanto; tampouco caberia reprovação sob o argumento de que existiriam alternativas à escolha do titular da competência, todas elas relativamente equivalentes entre si. E, em conclusão, que não caberia ao Poder Judiciário:

$$
\begin{aligned}
& \text { “(...) substituir-se ao titular da competência para realizar } \\
& \text { avaliações e estimativas no tocante à oportunidade, à } \\
& \text { consistência ou à finalidade de providências de natureza } \\
& \text { discricionária.” } 363
\end{aligned}
$$

\footnotetext{
${ }^{360}$ Direito Administrativo Brasileiro, p. 146.

${ }^{361}$ Direito Administrativo Moderno, p. 395.

362 Curso de Direito Administrativo, p. 948 e ss.

${ }^{363}$ Curso de Direito Administrativo, p. 993.
} 
Esse é também o entendimento de Jessé Torres PEREIRA JÚNIOR ${ }^{364}$, Juarez FREITAS $^{365}$, Elival da Silva RAMOS ${ }^{366}$, Maria Sylvia Zanella DI PIETRO ${ }^{367}$, dentre tantos outros.

Interessante é o posicionamento de Diogo de Figueiredo MOREIRA NETO que sustenta amplo controle de resultados dos atos administrativos, sob a ótica da legalidade. Sustenta o jurista que a sindicabilidade jurisdicional não reside na reavaliação do mérito, mas na verificação de que a conveniência e oportunidade do agente estatal tenham sido exercidas dentro dos limites técnicos de sua função e, pois, nesse sentido, o Poder Judiciário não examinaria o mérito do ato administrativo em si mas no que o exorbita. $^{368}$

Tomás-Ramón FERNANDEZ encabeça a corrente minoritária que considera possível, excepcionalmente, que Poder Judiciário -além de invalidar ou anular a decisão administrativa discricionária - dite a única solução juridicamente possível para o caso concreto, de acordo com o ordenamento jurídico. ${ }^{369}$

Essa mesma ordem de convicções apresenta Alexandre Santos do ARAGÃO ${ }^{370}$, Germana de MORAES $^{371}$, Mariano BACIGALUPO ${ }^{372}$ e Mariano MAGIDE $^{373}$.

Veja-se que essa corrente não corrobora o ativismo judicial, ao contrário, apenas para casos excepcionais e em que não haja dúvidas acerca da solução a ser adotada no caso concreto que se admite a possibilidade de que o magistrado venha a determiná-la em âmbito judicial.

Parece-nos mais acertado e pragmático esse posicionamento, com o qual concordamos. Frise-se que não entendemos nessa atuação do Poder Judiciário, tal como os

\footnotetext{
${ }^{364}$ Controle Judicial da Administração Pública: da legalidade estrita à lógica do razoável.

365 O Controle dos Atos Administrativos e os Princípios Fundamentais.

${ }^{366}$ Ativismo Judicial Parâmetros Dogmáticos.

${ }^{367}$ Discricionariedade Administrativa na Constituição de 1998.

${ }^{368}$ Legitimidade e Discricionariedade, p. 62.

${ }^{369}$ Debe la Administración actuar racional y razonablemente?

${ }^{370}$ Agências Reguladoras e a Evolução do Direito Administrativo Econômico, p. 353-354.

${ }^{371}$ Controle Jurisdicional da Administração Pública, p. 155.

372 La Discrecionalidad Administrtiva: estructura, control judicial y limites constitucionales de su atribución, p. 208.

${ }^{373}$ Limites Constitucionales de las Administraciones Independientes, p. 305.
} 
autores apontados, existir qualquer violação ao Princípio da Separação de Poderes, na medida em que se trataria de agir absolutamente vinculado aos ditames legais.

Fato é, todavia, que se sabe que o Poder Judiciário resiste a assumir até mesmo o controle judicial dos atos administrativos em sua forma negativa. ${ }^{374}$ Floriano de Azevedo MARQUES NETO afirma que tal resistência realiza-se até atavicamente e que o motivo alegado normalmente pelo Poder Judiciário é a tripartição de poderes, algo que efetivamente deve ser respeitado, pois constitui princípio angular do Estado de Direito. Contudo, tal princípio não pode ser utilizado como anteparo geral que impeça o controle judicial dos atos discricionários da Administração Pública. ${ }^{375}$

Com efeito, em matéria de controle judicial dos atos administrativos discricionários temos muito que evoluir no sentido de propiciar aos administrados efetiva possibilidade de ampla e irrestrita (sem reserva de mérito) anulação judicial de decisão arbitrária da Administração Pública. Parece-nos, assim, mais realista buscarmos a concretização do controle judicial das decisões administrativas discricionárias, primeiramente, em sua forma negativa. Essa já se revela, per se, como se pode inferir da doutrina colacionada acima, tarefa bastante árdua.

Por fim, para encerrarmos este capítulo, é imperioso tratarmos do controle judicial dos atos regulatórios discricionários, focando, assim, as discussões até agora apresentadas de maneira genérica no âmbito das decisões administrativas, nas decisões discricionárias das Agências Reguladoras.

\section{5. 2. O Controle das Decisões Regulatórias Discricionárias.}

A importância e complexidade do controle judicial das decisões regulatórias discricionárias estão diretamente relacionadas com a autonomia e independência das Agências Reguladoras e, bem assim, com o caráter multifacetário da atividade regulatória desempenhada por esses entes ${ }^{376}$, especialmente a sua competência para intervir

\footnotetext{
${ }^{374}$ Para uma visão geral do controle judicial dos atos regulatórios ver o interessante estudo de casos de Juliana Bonacorsi de PALMA, Daniel COLOMBO e Daniel WANG. Controle Judicial dos Atos Regulatórios: uma análise da jurisprudência, p. 120-150

375 Discricionariedade Administrativa e Controle Judicial da Administração, p. 195.

${ }^{376}$ A esse respeito ver a listagem precisa das atividades desempenhadas pelas Agências Reguladoras em Pensando o Controle da Atividade de Regulação Estatal de Floriano de Azevedo MARQUES NETO, p. 200 e ss.
} 
indiretamente em um dado setor da economia (telecomunicações, energia elétrica, gás e petróleo etc.) alcançando diretamente os agentes desse mercado, usuários potenciais e efetivos, mercados adjacentes (indústria e tecnologia, por exemplo) e interesses da coletividade em geral.

Nessa ordem de grandezas, o controle judicial das decisões regulatórias discricionárias revela-se como um importante instrumento para a defesa e proteção de interesses e direitos de todos os afetados direta e indiretamente pela intervenção regulatória realizada pelas Agências Reguladoras, especialmente, como tem nos demonstrado a prática, dos agentes de mercado.

Alexandre Santos de ARAGÃO sustenta que em relação ao Poder Judiciário, a independência das Agências Reguladoras não pode ser afirmada nos sistemas de unidade de jurisdição ${ }^{377}$, tal como o brasileiro, como vimos no início desse capítulo.

Tércio Sampaio FERRAZ afirma que o Poder Judiciário deveria necessariamente "ser levado a decidir sobre o mérito das regulações”, tomando-se a garantia do controle "em sua plena extensão".378

Não destoa o posicionamento de Sebastião Botto de Barros TOJAL para quem a racionalidade material do ato regulatório deveria ser apreciada pelo Poder Judiciário, inclusive para que se estabeleça o equilíbrio democrático na ação do Poder Executivo. ${ }^{379}$

De fato, em face das decisões discricionárias das Agências Reguladoras sempre será possível o acionamento do Poder Judiciário. ${ }^{380}$

As discussões a respeito do assunto giram em torno de três pontos: (i) da necessidade de deferência ou não das decisões discricionárias das Agências Reguladoras pelo Poder Judiciário, haja vista a discricionariedade técnica ${ }^{381}$ de que essas dispõem; (ii)

\footnotetext{
377 Agências Reguladoras e a Evolução do Direito Administrativo Econômico, p. 350.

${ }^{378}$ Agências Reguladoras: Legalidade Constitucionalidade, p. 157.

${ }^{379}$ Controle Judicial da Atividade Normativa das agências Reguladoras, p. 166.

380 Para conhecer o posicionamento dos tribunais no controle dos atos regulatórios discricionários ver Atualidades sobre o Controle Judicial dos Atos Regulatórios. Sérgio GUERRA, p. 14 e ss.

${ }^{381}$ Sobre o tema ver nosso Capítulo I, item II. 1. Vale à pena situar, também, a discussão sobre a necessidade de deferência à decisão administrativa no âmbito da jurisprudência americana onde, em 1984, a Suprema Corte dos Estados Unidos proferiu decisão que é considerada, até hoje, a mais importante decisão americana em matéria de revisão judicial dos atos administrativos. Trata-se do caso "Chevron, inc. versus National Resources Defense Council”, aplicável, conforme anota Marcos Paulo VERISSIMO, à atividade normativa das agências de regulação exercida por meio da interpretação de conceitos legais genéricos. Nesta decisão estabeleceu-se o princípio da deferência, comprovável em um duplo teste. O primeiro implicaria na
} 
do exercício da competência regulatória por peritos judiciais, chamados ao auxílio do juízo para a compreensão do objeto debatido nos autos; e (iii) da possibilidade de redução da efetividade regulatória gerada pela constante sujeição das decisões regulatórias discricionárias à revisão judicial.

O primeiro ponto atinente à possibilidade de revisão judicial das decisões fundamentadas em discricionariedade técnica apresenta a maior margem de debates e controvérsias. A esse respeito duas são as linhas encontradas na doutrina administrativista.

Uma afirma que as decisões regulatórias discricionárias, por seu embasamento técnico, não seriam passíveis de controle judicial, pois do contrário seria admitir que o juiz exercesse juízo de conveniência sobre a opção técnica do regulador, sem que detivesse capacidade específica que o habilitasse para tanto.

Sérgio GUERRA bem apresenta as preocupações dessa linhagem doutrinária:

$$
\begin{aligned}
& \text { “(...) se o julgador alterar um ato administrativo } \\
& \text { regulatório, que envolve, fundamentalmente, a eleição } \\
& \text { discricionária dos meios técnicos necessários para o } \\
& \text { alcance dos fins e interesses setoriais - despido das pressões } \\
& \text { políticas comumente sofridas pelos representantes } \\
& \text { escolhidos pelo sufrágio -, esse magistrado, na maioria das }
\end{aligned}
$$

verificação de que o texto legal realmente era vago e ambíguo. E, em caso positivo, partir-se-ia para o segundo teste, para se verificar se a interpretação conferida ao texto legal pela Administração Pública seria razoável ou não. Em sendo positivo também esse segundo teste, a decisão da Administração Pública não poderia ser substituída por outro do Poder Judiciário, devendo-se, pois, deferência à conclusão administrativa. Conforme nos informa Marcos Paulo VERISSIMO, o caso Chevron tem sido comumente mencionado na literatura americana mais como um paradigma de orientação do que propriamente como um precedente a ser fielmente seguido. Decisões mais recentes, ademais, indicam a mitigação do princípio da deferência estabelecido no caso Chevron, apontando para uma análise multifatorial das situações que se apresentam. Acerca da jurisprudência americana sobre o controle judicial dos atos administrativos e regulatórios ver o interessante, atual e completo artigo de Marcos Paulo VERISSIMO, Controle Judicial da atividade Normativa das Agências de Regulação Brasileiras, p. 393 e ss. Frisa-se, ainda, a aparente contradição do princípio da deferência do caso Chevron com o texto do Administrative Procedure Act, no qual se constata a possibilidade de controle judicial dos atos administrativos com base em critérios estabelecidos nesse documento. Por fim, com base na hard look doctrine, possibilita-se o controle dos atos administrativos de maneira pautada e aprofundada, especialmente nos casos que envolvem alguma discricionariedade técnica. Dois casos emblemáticos nesse sentido comumente apresentados são: Citizens to Preserve Overton Park versus Volpe e Motor Vehicle manufacturers Association of the United States Inc. versus State Farm Mutual Automobile Insurance Co. Acerca dos parâmetros para o controle dos atos administrativos no Administrative Procedure Act e na hard look doctrine ver Mateus Piva ADAMI,A Discricionariedade Administrativa em Face do Princípio da Eficiência. Dissertação de mestrado defendida na Faculdade de Direito do Largo São Francisco - USP em 2007. 
vezes, poderá, por uma só penada, afetar toda a harmonia e equilíbrio de um subsistema regulado." 382

Sustenta-se, nesse sentido, que o controle judicial, por ser balizado exclusivamente pelo Direito, não alcançaria os critérios metajuridicos inerentes às decisões técnicas das Agências Reguladoras, isto é, não seria suficiente para a confrontação dos parâmetros técnicos utilizados por esses entes.

Por esse pensamento, explica ainda o autor, o Poder Judiciário deve acatá-las, exercendo controle unicamente em relação aos erros manifestos que nelas se exteriorizam, de modo que a administração, nesses casos, goza de liberdade técnica de decisão, liberdade que, no entanto, não é absoluta visto que coartada quando o seu exercício resultar viciado por erro manifesto. ${ }^{383}$ Carlos Ari SUNDFELD e Jacintho Arruda CÂMARA também se posicionam nesse sentido. ${ }^{384}$

Fabio Medina OSÓRIO é taxativo:

"Nenhum Juiz parece estar preparado para controlar litígios que envolvem temas multidisciplinares, v.g., economia, sociologia, moral, em prazo fixado em semanas ou, no máximo meses. Esses controles judiciários têm se revelado claramente insuficientes, incapazes de inibir abusos que implicam o atropelamento de fórmulas legais ou mesmo constitucionais." 385

Eros Roberto GRAU aduz que existem decisões administrativas que supõem tal grau de especialização técnica que somente aquele que as toma, a partir de elementos altamente técnicos, poderia valorá-las. ${ }^{386}$

Marçal JUSTEN FILHO ${ }^{387}$, da mesma forma, expressa suas preocupações nesse sentido:

\footnotetext{
${ }^{382}$ Controle Judicial dos Atos Regulatórios, p. 272.

${ }^{383}$ Cf. Sérgio GUERRA. Atualidades sobre o Controle Judicial dos Atos Regulatórios, p. 14 e ss.

${ }^{384}$ Apontamentos sobre Agências Reguladoras. In: Agências Reguladoras. Alexandre de MORAES (Org.). São Paulo: Atlas, 2002, p. 36.

${ }^{385}$ Direito Administrativo Sancionador, p. 51.

${ }^{386}$ O Direito Posto e o Direito Pressuposto, p. 214.

${ }^{387}$ O Direito das Agências Reguladoras Independentes, p. 592.
} 
"Em grande parte dos casos, a atividade das agências refletirá conhecimentos técnico-científicos e atuação de especialistas. Os juízos e avaliações em que se fundam as decisões das agências poderão exteriorizar um conhecimento especializado dificilmente acessível ao funcionamento comum e normal do Poder Judiciário, cuja renovação na via judicial seja extremamente problemática. 388

O jurista paranaense exemplifica suas preocupações através de situação de operação de concentração empresarial de grande porte e, conclui que submeter ao controle judicial decisões regulatórias produzidas em casos com essas características - que demandam conhecimento técnico-científico - seria desastroso, haja vista que o Poder Judiciário não está afeito a manifestações de intervenção regulatória.

Conclui Marçal JUSTEN FILHO que, ademais, o Poder Judiciário não poderia substituir-se à autoridade administrativa no tocante às escolhas discricionárias. E, quando muito, poderia apontar a incorreção técnico-científica da decisão adotada pela Agência Reguladora ou a impossibilidade da justificação de sua adoção em face do conhecimento especializado ou das premissas consagradas na própria atuação anterior desta. Assim, seria vedado ao Poder Judiciário substituir a avaliação subjetiva da Agência Reguladora acerca da melhor solução a ser adotada no caso concreto. ${ }^{389}$

Não podemos, no entanto, ter a ingenuidade de achar que a tecnicidade é sempre acompanhada da imparcialidade, já que, salvo em casos limites, o saber técnico pode ser instrumentalizado em favor de diversos fins políticos. ${ }^{390}$

\footnotetext{
${ }^{388}$ O Direito das Agências Reguladoras Independentes, p. 592.

$389 \mathrm{O}$ autor reconhece, entretanto, o risco de que as Agências Reguladoras sejam utilizadas como instrumentos de neutralização do sistema de controles para a consecução de finalidades políticas. Diz o autor: "Nesse caso a Agência é mera fachada, exercitando competências no interesse de determinadas autoridades políticas. Sua existência não se destina a promover efetiva atenuação de pressões políticas no desenvolvimento do processo regulatório, mas a dificultar o exercício da fiscalização sobre seu desenvolvimento. A Agência torna-se um obstáculo formal ao exercício de controles externos sobre o poder político concentrado por determinadas instâncias políticas. (...) Decisões que poderiam ser objeto de controle e impugnação, se adotadas através do Executivo, são formalmente praticadas por uma agência. $O$ efeito prático consiste na atenuação das críticas na ampliação da autonomia governativa e na redução do sistema de controles sobre o governo. Mascara-se a decisão puramente política mediante sua implementação por meio de uma agência, a qual invoca critérios técnicos para produzir aquilo que é pura e simplesmente determinação oriunda de instâncias políticas superiores.” O Direito das Agências Reguladoras Independentes, p. 373.

${ }^{390}$ Agências Reguladoras e a Evolução do Direito Administrativo Econômico, p. 350.
} 
Não temos dúvidas de que as decisões regulatórias discricionárias, ainda que embasadas em critérios técnicos, não são absolutamente imunes a orientações provenientes dos altos escalões do governo e de grupos políticos e econômicos.

O processo decisório das Agências Reguladoras é permeado de influências de natureza não técnico-científicas. Existem, como elenca Marçal JUSTEN FILHO, conveniências político-partidárias, pressões de grupos econômicos e de organismos representativos de grupos empresariais e de usuários, manifestações da opinião pública e uma série indeterminada, ilimitada e imprecisa de fatores que condicionam a atuação das Agências Reguladoras. ${ }^{391}$

Não nos parece, portanto, ser admissível que se afirme a discricionariedade técnica como óbice ao amplo controle judicial das decisões regulatórias discricionárias.

Floriano de Azevedo MARQUES NETO é taxativo ao afirmar que nem mesmo a discricionariedade técnica das Agências Reguladoras poderia ser invocada para obstar o controle da atividade regulatória pela via judicial. ${ }^{392}$

Parece-nos, por conseguinte, que, até mesmo como reafirmação da independência e autonomia das Agências Reguladoras, seria imprescindível que as decisões regulatórias discricionárias fossem submetidas à ampla sindicabilidade judicial.

Novamente, Floriano de Azevedo MARQUES NETO sustenta que a ampla autonomia e independência das Agências Reguladoras fazem crescer a importância do controle exercido pelo Poder Judiciário sobre essas que se torna, pois, imprescindível. ${ }^{393}$.E, mais que isso, afirma que,

“(...) o controle judicial não deve ficar restrito á mera verificação de legalidade, mas deve atingir também, quando provocado, o juízo de proporcionalidade, na avaliação da

\footnotetext{
${ }^{391}$ Cf. Marçal JUSTEN FILHO. O Direito das Agências Reguladoras, p. 378.

${ }^{392}$ Agências Reguladoras Independentes - Fundamentos e seu Regime Jurídico, p. 127. No mesmo sentido é o posicionamento de Marçal JUSTEN FILHO, segundo o qual, rejeita-se a concepção de que um vasto setor de decisões regulatórias não dependeria da participação ou controle por órgãos externos às Agências Reguladoras porque fundadas em critérios técnicos. O Direito das Agências Reguladoras Independentes, p. 528.

${ }^{393}$ Agências Reguladoras Independentes - Fundamentos e seu Regime Jurídico, p. 127.
} 
necessidade, da adequação e da ponderação da medida regulatória em função dos objetivos da regulação." 394

“(...) Pois se é verdade que o juiz não pode substituir ao regulador, também é verdade que uma maior margem de discricionariedade dada aos agentes estatais no âmbito da moderna regulação estatal deve corresponder um controle mais robusto, inclusive pela via judicial." 395

Veja-se, que não há nisso, qualquer defesa pela possibilidade de substituição do regulador pelo juiz. Mas como afirmamos no item anterior, em uma afirmação pelo controle judicial amplo, objetivo e efetivo das decisões discricionárias da Administração Pública (e, por óbvio, também do regulador), em sua forma negativa.

O segundo ponto objeto de discussões acerca consistiria na possibilidade de substituição da avaliação técnica realizada pelo regulador por perito judicial escolhido pelo juiz para fornecer-lhe as informações técnicas do caso concreto e sobre essas esclarecerlhe. Afirma-se, a esse respeito, que o auxiliar de justiça, ainda que expert, não teria legitimidade para proceder a essa atividade, uma vez que essa seria restrita ao regulador, escolhido por critérios técnicos através de processo complexo que envolveria os Poderes Legislativo e Executivo. Carecia, então, o perito judicial, de legitimidade.

O terceiro ponto de discussão seria a possibilidade de redução da efetividade regulatória gerada pela constante sujeição das decisões regulatórias discricionárias à revisão judicial. Com efeito, esse nos parece ser um risco real ${ }^{396}$, mas necessário. Isso porque, o controle judicial das decisões regulatórias discricionárias revela-se, como afirmamos inicialmente, como um importante instrumento de defesa e proteção de interesses e direitos de todos os afetados direta e indiretamente pela intervenção regulatória realizada pelas Agências Reguladoras.

\footnotetext{
${ }^{394}$ Pensando o Controle da Atividade de Regulação Estatal, p. 246. 395 Agências Reguladoras Independentes - Fundamentos e seu Regime Jurídico, p. 127.

${ }^{396}$ Floriano de Azevedo MARQUES NETO reconhece a assunção de certos riscos para o exercício de um controle da proporcionalidade da atividade regulatória. Tais riscos, como menciona o autor, poderiam ser desde a possibilidade de que o juiz exerça, ao final, juízo de conveniência sobre a escolha técnica do regulador até a de que o substitua e, sucessivamente, reduza a efetividade regulatória em vista da constante sujeição das decisões regulatórias ao controle do Poder Judiciário. Agências Reguladoras Independentes Fundamentos e seu Regime Jurídico, p. 127-128.
} 
Mais a mais, como bem anota Marcos Paulo VERISSIMO, o maior ou menor grau de controlabilidade das decisões regulatórias discricionárias será pautado por uma série de outros fatores, como “(i) o grau de seriedade, imparcialidade e comprometimento da agência reguladora; (ii) sua abertura democrática, (iii) a legalidade e a transparência de seus procedimentos; (iv) o histórico de sua atuação, e (v) a coerência da norma administrativa com a ação pretérita do órgão". 397

Encerramos, assim, os pontos que reputamos relevantes apresentar acerca do tema do Controle Judicial dos Atos Administrativos e, especificamente, dos Atos Regulatórios. Passamos, pois, em vista do exposto ao longo deste capítulo, as nossas conclusões.

\section{6. Conclusões.}

Como vimos nas PARTES I e II da dissertação, a ampla margem de escolhas discricionárias à disposição das Agências Reguladoras - e, particularmente, da ANATEL pode perpetrar a imprevisibilidade, a incerteza e a insegurança jurídica nos setores regulados, não só indesejadas no cenário de moderna regulação, como também, antagônicas com os objetivos por essa buscados.

A regulação in concreto, assim, passa a ser compreendida pelos regulados como um evento de risco que pode impactar de maneira errática a gestão privada de seus negócios e produzir efeitos negativos na oferta e na prestação dos serviços públicos outorgados ou na atividade econômica explorada, com conseqüentes impactos, diretos ou indiretos, nos usuários (potenciais e efetivos) ou consumidores dos mercados afetados.

Nessa medida, se, por um lado, o incremento das escolhas do regulador é imprescindível, em vista da alta tecnicidade e complexidade das relações contemporâneas, por outro lado, é necessário que essa ampliação da discricionariedade das Agências Reguladoras seja compatibilizada com mecanismos que impeçam ou contenham o possível arbítrio e captura do regulador.

O controle judicial dos atos administrativos discricionários é um instrumento de extrema relevância nessa missão e encerra, em si, algumas das bases do Estado de Direito, especialmente representadas nos corolários de subsunção da Administração

${ }^{397}$ Controle Judicial da atividade Normativa das Agências de Regulação Brasileiras, p. 413. 
Pública ao ordenamento jurídico, de garantia e proteção dos direitos dos administrados e de inafastabilidade do controle judicial dos atos administrativos.

Este instrumento, entretanto, para que cumpra efetivamente com a sua função, não pode ser limitado ou cerceado. Deve ser pleno, direto, objetivo e contumaz. Reduzir a valoração subjetiva do agente estatal - incrustado na conveniência e oportunidade do mérito do ato administrativo - no exercício da discricionariedade e possibilitar o amplo e irrestrito controle das decisões administrativas discricionárias pelo Poder Judiciário revelase, assim, um grande desafio contemporâneo.

Essa empreitada mostra-se dificultosa não só em razão do que nos pareceu poder ser designado por imortalidade do mérito do ato administrativo, mas também em razão da timidez do Poder Judiciário em exercer efetivo e contundente controle dos atos discricionários da Administração Pública. Essa timidez é alargada, ainda, em se tratando de decisões regulatórias discricionárias em que os aspectos técnicos e as especificidades dos setores regulados parecem fornecer a escusa buscada pelos magistrados para que não procedam ao seu exame sequer na forma negativa.

Não obstante, parece-nos não existir dúvidas acerca da importância de se controlar a atividade estatal discricionária, especialmente a regulatória. Não que a incidência da regulação seja um mal em si, como bem ponderou Floriano de Azevedo MARQUES NETO. Muito ao contrário. Entendemos, com o jurista, que a regulação é necessária para que a ordem econômica se dirija as suas finalidades constitucionais, mas pode propiciar, ao menos, duas distorções que devem ser acompanhadas de perto pelos interessados e, especialmente, controladas pelo Poder Judiciário. A primeira é que o exercício do controle regulatório indireto pode ser tão grande sobre a iniciativa econômica que esvazie o princípio da liberdade de empresa. E, a segunda, é a ausência de neutralidade da regulação, ou, em outras palavras, a eleição de vencedores e perdedores, na medida em que, a escolha por um interesse em jogo sempre será detrimentosa para o outro. ${ }^{398}$

Diante, pois, da ausência de parâmetros concretos e objetivos que possibilitem auferir a ótima intervenção regulatória nos setores regulados e, bem assim, a correção e adequação dos limites da preponderância de um interesse legítimo sobre outro, a doutrina

${ }^{398}$ Limites à Abrangência e à Intensidade da Regulação Estatal, p. 92. 
administrativista recorre aos princípios gerais do direito para balizar as escolhas públicas discricionárias.

Com efeito, os princípios gerais do direito fornecem contornos ao exercício da discricionariedade pelas autoridades públicas e, bem assim, norteiam o controle das decisões administrativas discricionárias pelo Poder Judiciário.

Contudo, os princípios gerais do direito revelam-se como balizamentos deveras abstratos e intangíveis - como sói aos princípios - e, nessa medida, conferem alguma margem valorativa tanto à autoridade pública ao longo do processo decisório discricionário, como ao magistrado na atividade de controle das decisões administrativas discricionárias.

No nosso entender, embora sejam absolutamente respeitáveis os posicionamentos da doutrina estudada, há no controle dos atos administrativos discricionários por meio da avocação genérica aos princípios gerais do direito uma incoerência interna residente na tentativa de se controlar os aspectos subjetivos e valorativos dos atos administrativos discricionários com ferramentas de mesma ordem, isto é, com noções principiológicas que encerram, em verdade, concepções pessoais do seu aplicador ou intérprete.

É dizer que se pretende controlar o subjetivo com o abstrato, imaterial e intangível sem qualquer sistematização.

Essa tarefa parece-nos bastante árdua. E, mais que isso, parece-nos não inibir, ou impedir, a prática de decisões arbitrárias pelo regulador, tampouco, auxiliar o Poder Judiciário no exame in concreto do processo decisório discricionário das Agências Reguladoras.

Como já tivemos a oportunidade de afirmar, esse problema apresenta-se precisamente por não existirem parâmetros sólidos e objetivos para o acompanhamento do processo decisório das Agências Reguladoras e, bem assim, para o controle judicial do agir discricionário do regulador. Esses parâmetros teriam a função de conferir à aplicação dos princípios gerais de direito alguma concretude direta ou indireta.

Dedicaremos, assim, o próximo capítulo a apresentar uma proposta de critérios para a aferição da correção e adequação das escolhas regulatórias discricionárias, em seu 
aspecto positivo e negativo, e da adequação das decisões regulatórias discricionárias no âmbito da mediação ativa de interesses legítimos contrapostos. A proposta apresentada, ainda, teria a qualidade de permitir conhecer o caminho para a melhor solução juridicamente possível caso a caso. 


\section{CAPÍTULO V - PARÂMETROS DE CONTROLE DAS DECISÕES DISCRICIONÁRIAS DA ANATEL}

\section{1. Introdução.}

Eduardo García de ENTERRÍA e Thomáz-Ramón FERNÁNDEZ precisamente capturaram a problemática a ser enfrentada neste capítulo e com esses juristas retomamos, então, um dos questionamentos iniciais que fizemos na nota preliminar que abre a PARTE III dessa dissertação:

“la existência de potestades discricionales constituye por si
misma um desafio a las exigencias de la justicia, porqué?
Cómo controlar la regularidad y la objetividad de las
apreciaciones subjetivas de la Administración, cómo evitar
que invocando esa libertad estimativa se agrave en el caso
concreto de la equidad, cómo impedir que la libertad de
apreciación no pare en arbitrariedad pura y simple?? 399
(grifos nossos)

O desafio que ora se enfrenta é claro. Como impedir que a discricionariedade da ANATEL, nos casos de mediação ativa de interesses, converta-se, ao final, em arbitrariedade?

Dedicaremos, assim, esse capítulo à apresentação de uma proposta de critérios objetivos e concretos para a aferição da correção e da adequação das decisões regulatórias discricionárias, no âmbito de processos decisórios que exijam a mediação ativa de interesses pela ANATEL.

A proposta exposta a seguir busca corresponder aos novos tempos em que os atos administrativos precisam ser praticados e controlados sob uma ótica compatível com um Direito Administrativo mais dialógico, sinérgico, fundamentado e cooperativo ${ }^{400}$ e

\footnotetext{
${ }^{399}$ Curso de Direito Administrativo, p. 455.

${ }^{400}$ Cf. Juarez FREITAS. O Controle dos Atos Administrativos, p. 385.
} 
atender aos anseios de segurança jurídica (nas suas facetas da previsibilidade e da estabilidade) dos regulados em um contexto de patente risco. ${ }^{401}$

A mediação ativa de interesses, tal como definida no Capítulo I, é ambiente propício ao arbítrio e ao desvio de poder, haja vista que implica em amplo exercício discricionário dos reguladores e, pois, permite a produção de decisões casuísticas de difícil acompanhamento e controle. ${ }^{402}$

Esses casos revelam-se complexos porque demandam a ponderação de múltiplos interesses legítimos (dos regulados, usuários, fornecedores, players de outro mercado e do próprio Estado) contrapostos. Logo, normalmente, a solução desses casos não se encontra em uma única decisão possível, mas em algumas opções que devem ser sopesadas, de modo a que o regulador encontre e aplique aquela que seja a melhor solução ${ }^{403}$ juridicamente possível ao caso concreto.

A aplicação dos parâmetros propostos possibilitaria constatar se o regulador produziu, de fato, a melhor solução juridicamente possível no caso concreto, na medida em que permitiria aferir se, além de cumprir com todos os requisitos de legalidade, a decisão regulatória discricionária mostrou-se resultante de amplo e transparente processo decisório, fruto de diálogo e confrontação racional entre os interessados e entre esses e a ANATEL, deferente aos precedentes da Agência Reguladora, motivada positiva e negativamente e se proporcionou, senão à compatibilização ótima de todos os interesses envolvidos, o equilíbrio ideal entre o interesse satisfeito e o interesse sacrificado.

As bases de verificação da qualidade das decisões regulatórias discricionárias da ANATEL, nesse sentido, encontram-se nos quatros parâmetros propostos: (i) $a$ vinculação aos precedentes da ANATEL; (ii) a motivação positiva e negativa de todos os

\footnotetext{
${ }^{401}$ Cf. Celso Antonio BANDEIRA DE MELLO. Grandes Temas de Direito Administrativo, p. 168-180.

${ }^{402}$ Lembramos a esse respeito que a prova do desvio de poder é complexa e difícil em razão de sua natureza dissimulada. Remetemos, assim, o leitor especialmente às lições de J. CRETELLA JUNIOR destacadas em nosso Capítulo II.

${ }^{403}$ Adilson Abreu DALLARI bem anota que: "É certo que a lei sempre quer uma única solução: a melhor.Em certos casos (nos chamados atos vinculados) ela previamente assinala qual a melhor solução. Em outros casos (nos chamados atos discricionários) ela incumbe o administrador de descobrir, identificar, em cada caso, qual a melhor solução. Por isso está absolutamente errada a concepção segundo a qual a lei permite que o administrador escolha qualquer solução. Não, na verdade, ele tem o dever de adotar uma única solução: a melhor, que apenas não pode ser previamente identificada. Toda vez que se puder demonstrar que a solução adotada não é a melhor, é fatal concluir que houve ilegalidade, violação da vontade da lei." Controle do Desvio de Poder, p. 36.
} 
atos do processo decisório; (iii) a transparência do processo decisório; e (iv) a efetividade e o prognóstico da efetividade das decisões regulatórias discricionárias.

Esses parâmetros pressupõem, de antemão, como veremos, que a formação da decisão regulatória discricionária e a sua exteriorização se dêem de maneira racional e processualizada.

Releva esclarecer que os parâmetros propostos foram pensados a partir de nossas conclusões acerca do estudo de casos realizado no Capítulo III.

Note-se, por fim, que embora os parâmetros propostos tenham sido cunhados para os casos de mediação ativa de interesses no âmbito da ANATEL, sua utilidade pode ser estendida para outros casos concretos e Agências Reguladoras.

\section{2. A Importância de se Estabelecer Parâmetros Concretos e Objetivos} para a Atuação Regulatória Discricionária. Segurança Jurídica:

\section{Estabilidade e Previsibilidade.}

Em um contexto em que o plexo de escolhas regulatórias é amplo, os mecanismos que impõem alguma redução à discricionariedade e que possibilitam o controle das decisões discricionárias do regulador se fazem relevantes.

Essa relevância é marcada pela intenção de se erigir contornos claros entre o discricionário e o arbitrário, afinal, como vimos em nosso Capítulo II, discricionariedade não é arbitrariedade e, sob a roupagem da primeira, não deve se esconder a segunda.

Nessa tarefa, o estabelecimento de parâmetros concretos e objetivos para a atuação discricionária do regulador revela-se um importante ferramental para garantir, especialmente, a segurança jurídica dos regulados no seu viés de estabilidade das relações jurídicas e da previsibilidade das decisões regulatórias discricionárias. ${ }^{404}$

\footnotetext{
404 J.J.Gomes CANOTILHO destaca que as idéias nucleares do princípio da segurança jurídica giram em torno da estabilidade e da previsibilidade, nestes termos: "(i) estabilidade ou eficácia ex post da segurança jurídica: uma vez adoptadas, na forma e procedimento legalmente exigidos, as decisões estatais não devem poder ser arbitrariamente modificadas, sendo apenas razoável alteração das mesmas quando ocorram pressupostos materiais particularmente relevantes; e (2) previsibilidade ou eficácia ex ante do princípio da segurança jurídica que, fundamentalmente, se reconduz à exigência de certeza e calculabilidade, por parte dos cidadãos, em relação aos efeitos jurídicos dos actos normativos.” Direito Constitucional, p. 380.
} 
Tal importância é maior diante dos casos concretos que requerem a mediação ativa de interesses, uma vez que nesses, como apresentamos no Capítulo I, a discricionariedade do regulador é ainda mais alargada.

A segurança jurídica, embora não possa ser radicada em um dispositivo constitucional específico, é da própria essência do Estado Democrático de Direito e, pois, integra o sistema constitucional como um todo ${ }^{405}$. A estabilidade e a previsibilidade em suas relações correspondem aos primeiros anseios do homem. ${ }^{406}$

Nas palavras de Celso Antonio BANDEIRA DE MELLO:

\begin{abstract}
“Esta 'segurança jurídica' coincide com uma das mais profundas aspirações do Homem: a da segurança em si mesma, a da certeza possível em relação ao que o cerca, sendo esta uma busca permanente do ser humano. É a insopitável necessidade de poder assentar-se sobre algo reconhecido como estável, ou relativamente estável o que permite vislumbrar com alguma previsibilidade do futuro; $\underline{e}$ ela, pois que enseja projetar e iniciar consequentemente - $e$ não aleatoriamente, ao mero sabor do acaso -, comportamentos cujos frutos são esperáveis a médio e longo prazo. Dita previsibilidade é, portanto, o que condiciona a ação humana. Esta é a normalidade das coisas." ${ }^{407}$ (grifos nossos)
\end{abstract}

A segurança jurídica, desta feita, permite ao homem definir e planejar sua conduta na sociedade, tal como instituído pelo Direito. ${ }^{408}$

No mesmo sentido, Marçal JUSTEN FILHO afirma que o Estado de Direito obediente às normas jurídicas, elimina as soluções não conformes ou não previstas pelo Direito; de modo que os administrados podem organizar a vida presente e futura, tendo

\footnotetext{
${ }^{405}$ Cf. Celso Antônio BANDEIRA DE MELLO. Curso de Direito Administrativo, p. 123.

${ }^{406}$ No mesmo sentido é o entendimento de Luiz Guilherme MARINONI. Precedentes Obrigatórios, p. 121 e ss.

${ }^{407}$ Curso de Direito Administrativo, p. 124.

${ }^{408}$ Diogo de Figueiredo MOREIRA NETO, assevera, nesse sentido, que o Direito tem dupla vocação: “ $a$ de proporcionar segurança a uma sociedade e de fazer imperar a justiça em suas relações (...) o anseio de justiça é profundo e tem movido toda a evolução do Direito, é certo que desde as sociedades primitivas, a necessidade de segurança, que nos vem do próprio instinto, tem precedência lógica e cronológica, pois sem ela nenhuma ordem poderia sequer existir”. Mutações de Direito Público, p. 275.
} 
consciência de que a Administração Pública não adotará condutas vedadas ou não previstas no ordenamento jurídico. ${ }^{409}$

Em outras palavras, a ordem jurídica proporciona segurança jurídica, assegurando estabilidade e previsibilidade à atividade estatal e, nessa medida condicionando as ações dos administrados.

Como bem alerta Juarez FREITAS, "[a] instabilidade é fora de dúvida, geradora de relações perigosas entre administrador e particular. É má conselheira. Ao passo que a segurança jurídica tende a beneficiar, a longo prazo, a coletividade, o empreendimento idôneo e a probidade nas ralações de administração." 410

Sob o enfoque da confiança como decorrência da segurança jurídica, Jesús GONZÁLEZ PÉREZ afirma que em um Estado Democrático de Direito deve-se ter “ $a$ confiança de que não serão adotadas condutas confusas e equivocadas nos procedimentos nos quais serão emitidos os atos que gerarão as relações entre a Administração e o administrado (...)". 411

O Direito atua, assim, como instrumento que desperta nos administrados a confiança $^{412}$ de que a Administração Pública atuará de acordo com as regras do jogo e, com base nessas regras, esses definem e executam suas ações. ${ }^{413}$

Robert THOMAS, nesse sentido, assevera que:

"a confiança nas ordens do Estado deve ser respeitada. A
confiança é um fator básico da vida social. Na atual
conjuntura de complexidade social é essencial para o
indivíduo confiar no Governo para desenvolver suas

${ }^{409}$ Curso de Direito Administrativo, p. 1097.

${ }^{410}$ O Controle dos Atos Administrativos, p. 99.

${ }^{411}$ El Principio General de la Buena Fe em el Derecho Administrativo, p. 91.

${ }^{412}$ Acerca dos aspectos objetivo e subjetivo da segurança jurídica ver o sempre lembrado artigo de Almiro do Couto e SILVA. O Princípio da Segurança Jurídica (Proteção à Confiança) no Direito Público Brasileiro e o Direito da Administração Pública de Anular seus próprios Atos Administrativos. Sobre o tema ver também a excelente monografia de Rodrigo Bracet MIRAGAYA em que o autor relaciona de maneira precisa as interfaces da segurança jurídica com a proteção da confiança, boa-fé e moralidade. A Proteção da Confiança Legítima como Princípio Fundamental no Direito Administrativo. Dissertação de Mestrado. Faculdade de Direito do Largo São Francisco da Universidade de São Paulo, 2010.

${ }^{413}$ Por essa razão Celso Antonio BANDEIRA DE MELLO afirma que o princípio da segurança jurídica é tão valioso que "sua violação compromete toda a instituição que o transgride, ao trair a confiança geral, cimento das civilizações, e a boa-fé dos que deveriam ser protegidos pela ordem jurídica.". Curso de Direito Administrativo, p. 124. 
atividades. Um empreendedor não pode de maneira alguma operar se ele não puder ter um mínimo de confiança no Estado. As expectativas legítimas compelem a Administração a ser confiável, uma vez que o indivíduo não tem outra escolha, a não ser confiar nela ao desenvolver as suas atividades." ${ }^{414}$ (grifos nossos)

Essa ordem de fatores transportada, assim, à esfera regulatória evidencia, ainda mais, a importância da atuação das Agências Reguladoras de acordo com o Direito, isso porque, como já tivemos a oportunidade de destacar, a intensidade e o alcance da intervenção regulatória afetam com profundidade a atividade empresarial em diversos mercados (principal e adjacentes) e produzem efeitos que alcançam incontáveis usuários e consumidores.

A atuação discricionária das Agências Reguladoras deve, pois, estar pautada, impreterivelmente, nos bordes da segurança jurídica, preservando-se a estabilidade do subsistema regulado $^{415} \mathrm{e}$ a previsibilidade das ações, opções, condutas e decisões regulatórias.

Os parâmetros concretos e objetivos que propomos nessa dissertação intentam, portanto, exatamente mitigar a insegurança jurídica nas relações travadas entre a ANATEL e os regulados e, por conseguinte, afastar o arbítrio do regulador. Os critérios propostos buscam, assim, balizar a atuação da ANATEL de acordo com a ordem jurídica, proporcionando o acompanhamento do processo decisório da Agência Reguladora pelos interessados e constituindo pontos precisos de controle judicial das decisões regulatórias discricionárias.

É, pois, nessa medida, que nossa proposta revela a sua importância.

Antes, porém, de passarmos à apresentação de nossa proposta, cumpre fixar os seus pressupostos na racionalidade da decisão regulatória discricionária e no próprio processo decisório conquanto instrumento imprescindível à produção do ato final.

\footnotetext{
${ }^{414}$ Legitimate Expectations and Proportionality, p. 45.

415 Sergio GUERRA bem observa que, no ambiente regulatório, a segurança jurídica deve estar apoiada no equilíbrio cíclico e auto-referencial sistêmico. Discricionariedade e Reflexividade, p. 391.
} 


\section{3. A Racionalidade dos Juízos de Ponderação do Regulador.}

A busca pela racionalidade dos juízos de ponderação do regulador parece ser uma constante no Estado Contemporâneo. Reduzir a discricionariedade das Agências Reguladoras em um momento de alargado conjunto de escolhas regulatórias é imprescindível para conter o arbítrio e conferir aos regulados algum grau de segurança jurídica e previsibilidade.

Intenta-se, hodiernamente, por diversas ferramentas, afastar o subjetivismo do regulador e propiciar que suas decisões sejam baseadas em critérios objetivos, isto é, que a análise dos fatos, a avaliação do direito, o exame dos dados, informações e argumentos aportados aos autos e o sopesamento dos interesses em jogo sejam realizados sob a ótica da razão e não das concepções pessoais do regulador. ${ }^{416}$

Juarez FREITAS bem fotografa o atual momento:

"Hora, com efeito, de erguer, com equilíbrio prudente, o Direito Administrativo alicerçado na saudável racionalidade dialógica e multiforme. Tempo de favorecer o controle sistemático da eficiência e da eficácia, na rota de cobrar motivação abrangente dos atos discricionários $e$ vinculados, ao oposto da ancoragem ilusória no abstrato ingênuo ou na liberdade irrestrita do decisionismo irracional." ${ }^{417}$ (grifos nossos)

"Nessa lógica, não remanesce lugar para a discricionariedade emotiva desmesurada e pelo formalismo axiomatizante." 418

Contudo, como vimos ao tratar do tema do controle dos atos administrativos discricionários no Capítulo IV, não há consenso acerca da possibilidade de se reduzir a zero o subjetivismo do regulador diante de sua possibilidade de realizar escolhas ao ponderar os interesses envolvidos no caso concreto e de escolher qual desses deve preponderar. É dizer que normalmente a discricionariedade é associada diretamente a

416 Vale a pena conhecer o estudo realizado por Cesar A. Guimarães PEREIRA, em seu artigo Discricionariedade e Apreciações Técnicas da Administração, em que o autor apresenta e articula as Teorias de Robert ALEXY, MACCORMICK e Manuel ATIENZA acerca da racionalidade jurídica.

${ }^{417}$ O Controle dos Atos Administrativos, p. 398.

${ }^{418}$ Discricionariedade Administrativa e o Direito Fundamental à Boa Administração Pública, p. 20. 
reserva subjetiva de escolha do regulador. Como se a esse fosse assegurado declarar vencedores e perdedores nas situações que lhe são apresentadas meramente de acordo com seu juízo pessoal de valores.

Esse equívoco ocorre normalmente porque se associa quase que diretamente a discricionariedade à valoração (atribuir valor a algo) e essa, por conseguinte, remeteria automaticamente às noções subjetivas da autoridade pública, assegurando-se uma esfera de decisão insindicável, etiquetada de mérito do ato administrativo decisório ou de conveniência e oportunidade.

Essa associação é ainda mais espontânea e fluente em se tratando de casos concretos que demandam a mediação ativa de interesses em setores regulados. Isso porque a própria atividade mediadora dos interesses em jogo - antes mesmo da valoração intrínseca a essa atividade - revelaria alguma subjetividade do regulador.

Não vemos na discricionariedade, como já deixamos evidente nessa dissertação, uma reserva para a decisão subjetiva do regulador, mas um espaço para a ponderação racional de todos os elementos que compõem o caso concreto para que a melhor solução juridicamente possível seja a esse aplicada. Muito menos concordamos que tal reserva exista em face da discricionariedade técnica das Agências Reguladoras, em que à ponderação racional mencionada adiciona-se a avaliação objetiva das questões técnicas que permeiam o caso concreto. ${ }^{419}$

Temos convicção de que a discricionariedade ou a abertura para a ponderação e valoração ${ }^{420}$ dos elementos do caso concreto pode e deve ser um processo racional e, não subjetivo, do regulador, realizado com base em critérios objetivos e, pois auferível pelos interessados e pelos órgãos de fiscalização, notadamente pelo Poder Judiciário. $^{421}$

\footnotetext{
${ }^{419}$ Marçal JUSTEN FILHO bem anota a esse respeito que "[o] universo da atuação da agência reguladora envolve, então, uma séria de decisões que se relacionam com temas técnicos, mas que neles não se exaure". O Direito das Agências Reguladoras Independentes, p. 529.

${ }^{420}$ Reconhecemos que o termo valoração é ambíguo, por isso, cumpre esclarecer que o utilizamos aqui em seu conceito semântico de atribuir valor a algo ou alguém. Ilustrado didaticamente por Robert ALEXY como " $x$ é bom". Teoria dos Direitos Fundamentais, p. 148.

${ }^{421}$ Veja-se que o raciocínio jurídico e o raciocínio econômico não são excludentes. Sobre o tema ver Raciocínio Jurídico e Economia. José Reinaldo de Lima LOPES..
} 
Robert ALEXY em seu Teoria dos Direitos Fundamentais ${ }^{422}$ explora como ninguém o tema da racionalidade dos juízos de ponderação de princípios e valores. ${ }^{423} \mathrm{O}$ jurista com perspicácia, assim, identifica a problemática que envolve a idéia de sopesamento e valoração de interesses:

"Contra a idéia de sopesamento é muitas vezes levantada a objeção de que ela não é um modelo aberto a um controle racional. Valores e princípios não disciplinam, sua própria aplicação, e o sopesamento, portanto, ficaria sujeito ao arbitrio daquele que sopesa.Onde começa o sopesamento terminaria o controle por meio de normas e métodos. Ele abriria espaço para o subjetivismo e o decisionismo dos juízes." ${ }^{424}$ (grifos nossos)

De acordo com o autor, a objeção à idéia de sopesamento estaria na impossibilidade de se estabelecer um controle normativo e metodológico racional sobre esse, o que importaria em decisões subjetivas e, por conseguinte, não controláveis.

O próprio jurista analisa a problemática posta:

“Essas objeções são procedentes se com elas se quiser dizer que o sopesamento é um procedimento que conduza, em todo e qualquer caso, a um resultado único e inequívoco. Mas elas não são procedentes quando daí se conclui que o sopesamento é um procedimento não-racional ou irracional." 425

De fato, dos processos de sopesamento e valoração realizados pelo regulador em sua esfera discricionária, múltiplas possibilidades de decisão são possíveis, o que não quer dizer que essas não sejam racionais, ou que sejam subjetivas, isto porque, ainda que mais de uma escolha regulatória seja possível, essas devem ser resultado de um processo racional de avaliação de todos os elementos do caso concreto apresentados ao regulador.

\footnotetext{
${ }^{422}$ Em que pesem as críticas a sua Teoria, especialmente as de Habermas.

${ }^{423}$ Ver a esse respeito o item III do capítulo 3 de sua obra: Teoria dos Princípios e Teoria dos Valores, p. 144-179. Embora construída sob o enfoque judicial, a Teoria tem plena aplicabilidade ao universo regulatório.

${ }^{424}$ Teoria dos Direitos Fundamentais, p. 163-164.

${ }^{425}$ Teoria dos Direitos Fundamentais, p. 164.
} 
Esse processo racional de acordo com Robert ALEXY compõe o que o autor denomina de modelo fundamentado de decisão em contraposição ao modelo decisionista. Conforme explica o jurista, o resultado de ambos os modelos é um enunciado de preferência condicionado. Porém, no modelo decisionista a definição do enunciado de preferência é o resultado de um processo psíquico não controlável racionalmente e, no modelo fundamentado, há diferenciação entre o processo psíquico que conduz à definição do enunciado de preferência e a sua fundamentação, o que permitiria vincular a racionalidade do sopesamento à fundamentação do enunciado de preferência. ${ }^{426}$

A base da racionalidade estaria, assim, na fundamentação da ordem de preferências estabelecidas pelo regulador.

Robert ALEXY, ainda, propõe os alicerces da fundamentação para que o sopesamento seja realizado em bases racionais. Dois seriam os parâmetros para tanto: um seria a Lei do Sopesamento, segundo a qual "a medida permitida de não satisfação ou de afetação de um princípio depende do grau de importância da satisfação do outro”; outro seria a produção de enunciados que sustentassem o grau de afetação e de importância da prevalência. Para a produção desses enunciados poder-se-ia utilizar das ferramentas de argumentação juridicamente reconhecidas. ${ }^{427}$

A máxima da necessidade é implícita na Lei do Sopesamento, de modo que, nos parece ser um norte a pautar a intensidade das preferências estabelecidas pelo regulador em vista da ponderação e valoração dos fatos, direitos, dados, informações, argumentos, questões técnicas e interesses em jogo no caso concreto.

Mais que isso, intentamos propor parâmetros concretos e objetivos que possibilitem uma fundamentação da ordem, da intensidade e da importância das prevalências estabelecidas pelo regulador, de modo a que a racionalidade seja a tônica dos juízos de ponderação do regulador e que se expurgue a arbitrariedade transvestida de discricionariedade das decisões regulatórias. Em outras palavras, pretendemos contribuir para que as decisões regulatórias discricionárias sejam decisões racionalmente fundamentadas.

\footnotetext{
${ }^{426}$ Teoria dos Direitos Fundamentais, p. 165.

${ }^{427}$ Teoria dos Direitos Fundamentais, p. 171.
} 
Ademais, como já registramos oportunamente no Capítulo IV, o estabelecimento desses parâmetros não só auxiliariam ao próprio regulador no processo decisório e, indiretamente, poderiam propiciar a melhoria da qualidade das decisões regulatórias $^{428}$, como também, possibilitariam o acompanhamento dos interessados e lhe proveriam alguma segurança jurídica e previsibilidade e, ainda, possibilitariam um controle judicial mais adequado das decisões regulatórias discricionárias.

Como veremos adiante, partimos também do pressuposto da atuação processualizada e dialógica do regulador para, então, fixar seu ponto de partida na análise de precedentes da Agência Reguladora, permeando o processo decisório do regulador de ampla motivação positiva e negativa e de absoluta transparência com, ao final, o exercício prognóstico da efetividade da decisão regulatória produzida.

\section{4. O Pressuposto Agir Administrativo Adstrito ao Processo.}

O tema do processo administrativo está em pauta. Os manuais de Direito Administrativo dão-lhe especial atenção. ${ }^{429}$ Inúmeras obras e artigos jurídicos específicos sobre o tema foram e continuam a ser produzidos. ${ }^{430}$

Em âmbito normativo, em 1999, a Lei n. ${ }^{\circ}$ 9.784/1999 regulou o processo administrativo no âmbito da Administração Pública Federal, consolidando, de maneira geral, o instituto antes já reconhecido como decorrência direta do texto constitucional. A partir de 1993, entretanto, várias leis passaram a conter capítulos dedicados ao processo administrativo, como é o caso da Lei n. ${ }^{\circ} 8.884 / 1994$ e da Lei n. ${ }^{\circ} 8.666 / 1993 .{ }^{431}$ Nesse cenário, as Agências Reguladoras foram criadas já em um cenário processualizado, no qual são regidas evidentemente pela Lei de Processo Administrativo Federal e por disposições específicas constantes de suas leis e regulamentação própria.

\footnotetext{
${ }^{428}$ Cf. Diogo de Figueiredo MOREIRA NETO. Legitimidade e Discricionariedade, p. 61.

${ }^{429}$ Destacam-se de Celso Antonio BANDEIRA DE MELLO, Curso de Direito Administrativo; de Odete MEDAUAR, Direito Administrativo Moderno; e de Marçal JUSTEN FILHO, Curso de Direito Administrativo.

${ }^{430}$ Vale conhecer de Odete MEDAUAR, A Processualidade no Direito Administrativo; de Egon Bockmann MOREIRA, Processo Administrativo, e coordenado por Carlos ali SUNDFELD a coletânea de artigos As Leis de Processo Administrativo. No cenário internacional, excelente á a obra de David DUARTE. Procedimentalização, Participação e Fundamentação: para uma concretização da imparcialidade administrativa como parâmetro decisório.

${ }^{431}$ Cf. Odete MEDAUAR. O Direito Administrativo em Evolução, p. 228.
} 
Na matéria de propositura de parâmetros para o acompanhamento e controle das decisões administrativas discricionárias pelos interessados e pelo Poder Judiciário, $o$ processo administrativo $^{432}$ é pressuposto, na medida em que possibilita a externalização do processo cognitivo que esta na base da discricionariedade. Essa pressuposição funda-se nas transformações da relação jurídica entre a Administração Pública e os administrados, como veremos, de maneira breve, nesse item da dissertação.

O processo administrativo ${ }^{433}$ - compreendido como o encadeamento ordenado e sucessivo de atos confluentes para um ato final - é o modo normal de agir da Administração Pública e conseqüência direta da idéia de função estatal. ${ }^{434}$

Floriano de Azevedo MARQUES NETO observa, contudo, que o processo administrativo não só “é o modo pelo qual, no Estado Democrático de Direito, se exerce o poder estatal com vistas a cumprir alguma das atribuições reservadas pela Constituição ao ente Estado.”. É mais que isso, vai além da mera sucessão ordenada de atos progressivos. Para o autor o processo administrativo assume-me como uma relação jurídica progressiva, da qual fazem parte não só os agentes estatais competentes, mas os diferentes e múltiplos interesses contrapostos na ação. ${ }^{435}$

Segundo o jurista, essa relação jurídica decorre do dever processual da atuação estatal, fruto da sujeição dos administrados ao poder estatal em um Estado Democrático de Direito $^{436}$, em que a manifestação estatal está adstrita ao método predicado para tal mister. É dizer que no Estado de Direito - ao contrário dos Estados não democráticos - importa

\footnotetext{
${ }^{432}$ Assegurado como direito fundamental pelo art. 5, ${ }^{\circ}$ LV da Constituição Federal.

${ }^{433}$ Não entraremos na discussão acerca dos termos processo e procedimento. Optamos por utilizar o termo processo, pois nos é mais familiar, embora reconheçamos as lições de Carlos Ari SUNDFELD em A Importância do Procedimento Administrativo, p. 72 e ss. Sobre o tema ver também Odete MEDAUAR em A Processualidade no Direito Administrativo, p. 33 e ss.

${ }^{434}$ Cf. Carlos Ari SUNDFELD. Importância do Procedimento Administrativo, p. 67. A respeito das funções estatais ver nosso Capítulo II.2.

${ }^{435}$ Floriano de Azevedo MARQUES NETO. Ensaio sobre o Processo como Disciplina do Exercício da Atividade Estatal, p. 266.

${ }^{436}$ Conforme afirma o autor, "[o] Estado Democrático de Direito obriga que, para o exercício deste poder (de forma singular ou colegiada, de modo isolado ou complexo), seja estritamente observado o método predicado para tal mister. Na medida em que o indivíduo, o cidadão, é sempre afetado, direta ou indiretamente, pela manifestação do poder estatal, estabelece-se uma relação de sujeição permanente daquele em relação a este. Esta relação de sujeição impõe o estabelecimento de requisitos para sua manifestação em concreto. Sempre que essa sujeição em abstrato se traduz em sujeição concreta (ou seja, sempre que de alguma forma o indivíduo é afetado pela manifestação do poder estatal), impõe-se o estabelecimento da relação jurídico-processual, que observará a prescrição de ritos, princípios e condições - em uma palavra, o método - estatuídos para aquela específica atuação estatal.” Floriano de Azevedo MARQUES NETO. Ensaio sobre o Processo como Disciplina do Exercício da Atividade Estatal, p. 266.
} 
também o modo pelo qual o poder se manifesta. Daí falar-se no deslocamento da manifestação estatal do ato (decisão) para o método (processo). ${ }^{437}$

Não faz muito tempo, entretanto, que o papel nuclear no Direito Administrativo, conferido ao ato $^{438}$, deu lugar ao processo administrativo. ${ }^{439}$

É dizer que a escolha subjetiva da autoridade estatal emanada unilateralmente e concretizada no ato administrativo deu lugar à decisão discricionária resultante de um processo administrativo no qual, passo a passo, a opção da Administração Pública é construída e justificada, com base nos fatos, nos fundamentos jurídicos, nas informações técnicas e especializadas e na participação ativa dos interessados. ${ }^{440}$ Passa-se, assim, a decisão discricionária da seara pessoal, individual e subjetiva da autoridade pública para a esfera coletiva, externa e objetiva do processo administrativo.

Essa transformação, como explica Egon Bockmann MOREIRA, na mesma linha de Floriano de Azevedo MARQUES NETO, deveu-se à impossibilidade de se defender, nos dias atuais, uma postura que prestigie a um só dos lados da relação jurídicoadministrativa (o da Administração Pública) e que apenas esse possa impor as soluções. ${ }^{441} \mathrm{O}$ jurista assevera, nesse sentido, que o Direito Administrativo evoluiu à

${ }^{437}$ Cf. Floriano de Azevedo MARQUES NETO. Ensaio sobre o Processo como Disciplina do Exercício da Atividade Estatal, p. 266-267.

${ }^{438}$ Sabino CASSESE aponta duas razões para a passagem do ato para o processo no Direito Administrativo: (i) reconhecimento pela jurisprudência administrativa de que a atividade administrativa era eminentemente seqüencial (ato trâmite - ato final) ao diferenciar ato preparatório de ato final para fins de impugnação por vício e (ii) influência dos estudos da ciência jurídica que apontaram para a diferença entre as decisões próprias das organizações privadas (não reguladas) e da Administração Pública, cujo procedimento prévio é intensamente normatizado. Las Bases del Derecho Administrativo, p. 250. Vasco Pereira da SILVA, por sua vez, apresenta quatro razões para a denominada crise do ato administrativo: (1) o modelo de Administração Pública em que se verificou a construção teórica do ato administrativo já não mais existe; (2) o ato administrativo perdeu seu papel de protagonista com a manifestação da atividade administrativa por meio de outras formas, como os contratos; (3) o ato administrativo integra um quadro mais vasto de relação jurídicoadministrativa, qual seja, o processo administrativo; (4) afastamento da definitividade da executoriedade do domínio da recorribilidade pelo constituinte português (esse último canal mais específico ao caso lusitano). Em Busca do Acto Administrativo Perdido, p.5.

${ }^{439}$ Para conhecer a gradual incorporação da idéia de processo administrativo no Direito Administrativo brasileiro ver, por todos, Carlos Ari SUNDFELD, no seu Introdução ao Processo Administrativo, p. 20 e ss.

440 "El principio de oír al interessado y al público antes de decidir algo que los va a afectar no es solamente um principio de justicia: es también um principio de eficacia; porque indudablemente asegura um mejor conocimiento de los hechos y por lo tanto ayuda a uma mejor administración además de a uma más justa decisión, com menor o ningún costo político." Agustín GORDILLO. Tratado de Derecho Administrativo, p. VIII-18.

${ }^{441}$ Nesse sentido afirma o jurista que "[e]nfim, os diplomas legislativos vêm atribuindo uma dignidade ímpar ao processo administrativo - reconhecendo o seu papel sobranceiro frente a um Estado Democrático de Direito.". O Processo Administrativo no Rol dos Direitos e Garantias Individuais, p. 128 e ss. Carlos Ari SUNDFELD afirma que se esconde na tendência de se considerar pouco ou nada relevante a atividade da 
consensualidade na produção dos atos administrativos e, para tanto, o processo administrativo tornou-se primordial. ${ }^{442}$

Caio Tácito aponta que "o Direito Administrativo contemporâneo tende ao abandono da vertente autoritária para valorizar a participação de seus destinatários finais quanto à formação da conduta administrativa" 443

Egon Bockmann MOREIRA salienta que em vista dessas transformações não é mais possível entender o processo administrativo - como há tempos atrás ocorria - como uma figura secundária, como um singelo direito adjetivo do Direito Administrativo material, como mero meio de defesa do administrado contra os excessos estatais, ou ainda, como um ingênuo acessório do Direito Administrativo. ${ }^{444}$

O cenário atual é outro. O processo administrativo aparece como expressão do Estado Democrático de Direito. Ou, ainda, como decorrência e pressuposto do Estado Democrático de Direito. ${ }^{445}$

Como asseverou CANOTILHO, "[a] exigência de um procedimento juridicamente adequado para o desenvolvimento da actividade administrativa considerase como dimensão insubstituível da administração do Estado de direito democrático.” 446

E no Estado Contemporâneo, mais consensual e menos autoritário, exige-se como condição de legitimidade das ações estatais a participação ${ }^{447}$ (nos mais variados graus) nos processos administrativos daqueles que por essas serão atingidos, positiva ou negativamente. $^{448}$

Administração Pública que não se enquadre no conceito restrito de ato (ou nesse não possa ser reduzida) uma visão autoritária (ainda) que impede a constatação de que qualquer função administrativa para ser desenvolvida depende de um procedimento juridicamente regulado e relevante. Importância do Procedimento Administrativo, p. 67 e 70.

442 O Processo Administrativo no Rol dos Direitos e Garantias Individuais, p. 131-132.

${ }^{443}$ Direito Administrativo Participativo, p. 25.

${ }^{444}$ O Processo Administrativo no Rol dos Direitos e Garantias Individuais, p. 128 e 132.

${ }^{445}$ Cf. Floriano de Azevedo MARQUES NETO. Ensaio sobre o Processo como Disciplina do Exercício da Atividade Estatal, p. 261.

${ }_{446}$ Direito Constitucional e Teoria da Constituição, p. 318.

${ }^{447}$ Vasco Manuel Pascoal Dias Pereira da SILVA ressalta que "[p]erante uma Administração Pública que não cessa de crescer em termos de intervenção e de autonomia, o incremento da participação dos privados na tomada de decisões administrativas representa uma importante forma de controle e de limitação do poder administrativo”. Texto adaptado à gramática e semântica do português nacional. Em Busca do Acto Administrativo Perdido, p. 401.

${ }^{448}$ Veja-se que não estamos aqui nos referindo tão-somente à participação em termos do devido processo legal, ampla defesa e contraditório, há muito consagrados no art. $5^{\circ}$ da Constituição Federal. Referimo-nos, 
O processo administrativo como instrumento de participação do administrado nos processos decisórios da Administração Pública apresenta-se, assim, como importante garantia democrática. ${ }^{449}$

Ademais, como bem observa, Vasco Manuel Pascoal Dias Pereira da SILVA, “a participação dos privados no procedimento, ao permitir a ponderação pelas autoridades administrativas dos interesses de que são portadores, não só se traduz numa melhoria de qualidade das decisões administrativas, possibilitando à Administração uma mais correta configuração dos problemas das diferentes perspectivas possíveis da sua resolução, como também torna as decisões administrativas mais facilmente aceitas pelos seus destinatários". 450

A relação jurídico-administrativa vigente deve, então, ser vislumbrada como uma convivência harmoniosa e participativa, em que os administrados interagem $e$ colaboram na produção dos atos administrativos através do processo administrativo. ${ }^{451}$

Nas palavras de Egon Bockmann MOREIRA:

"Inverteu-se a óptica primordial: de provimentos emanados unicamente das entranhas da Administração Pública, tornaram-se os atos administrativos (individuais $e$ concretos; gerais e abstratos) decisões oriundas da cooperação entre as pessoas privadas e a Administração. Aos particulares se firmou o direito e a garantia de participar da elaboração dos atos administrativos a ser

especialmente,à participação dialógica e dinâmica entre a Administração Pública e os interessados em busca da composição de conflitos de interesses legítimos. Como bem asseverou Vasco Manuel Pascoal Dias Pereira da SILVA: "A participação é não apenas consubstanciada no instituto do contraditório, mas destinada à 'ponderação dos interesses', sendo o seu escopo principal a composição material dos interesses.” Em Busca do Ato Administrativo Perdido, p. 406. Cármen Lúcia Antunes ROCHA afirmou oportunamente a esse respeito que: "O processo administrativo democrático não é senão o encontro da segurança jurídica justa. Ela é uma das formas de concretização do princípio da legitimidade do poder, à medida que se esclarecem e se afirmam os motivos das decisões administrativas. Tais decisões são questionadas e deslindadas no processo administrativo e, nessa sede, o poder no exercício do qual elas foram adotadas recebe a sua condição legítima própria. Quanto mais democrático for o processo administrativo, mais demonstrativo ele é da essência e prática do exercício do poder em determinado estado." Princípios Constitucionais do Processo Administrativo no Direito Brasileiro, p. 5-6.

${ }^{449}$ Ver a esse respeito Participação Administrativa. Gustavo Henrique Justino de OLIVEIRA, p. 209-229.

${ }^{450}$ Em Busca do Ato Administrativo Perdido, p. 402.

${ }^{451}$ O Processo Administrativo no Rol dos Direitos e Garantias Individuais, p. 128 e ss. 
futuramente emanados pelo Estado-Administração." 452 (grifos nosso)

A processualidade participativa ${ }^{453}$ condiciona o exercício da discricionariedade pela autoridade pública, uma vez que a decisão discricionária deixa de ser tomada como uma decisão autoritária, unilateral, e passa a ser resultado de um processo participativo, em que os interessados contribuem aportando dados, informações e argumentos para a formação da decisão administrativa, possibilitando, assim, à autoridade pública, de maneira mais fidedigna, a identificação das razões prevalecentes.

O processo administrativo responde, ainda, sob outro enfoque, ao dinamismo da atividade administrativa, no qual a decisão estatal não se encontra meramente no ato final, mas decorre da conjugação dos atos que lhe precede, tal como ponderamos inicialmente.

A doutrina administrativista destaca, nesse sentido, que, por um lado, a condição estática do ato administrativo não fazia frente à condição dinâmica da ação administrativa e, por outro lado, que a noção de processo permite captar e submeter a controle o dinamismo do desempenho das funções estatais. ${ }^{454}$

É que a decisão administrativa (vinculada ou discricionária, importando-nos especificamente esta última) produz-se paulatinamente ao longo do processo decisório. ${ }^{455} \mathrm{O}$ processo administrativo, ou nas palavras de Marçal JUSTEN FILHO, a procedimentalização, impede, nesse movimento de caminhar, a concentração decisória num ato imediato e único e de escolhas fundadas em critérios meramente subjetivos de autoridade. $^{456}$

Com efeito, a submissão do agir administrativo à procedimentalização acaba por implicar que as opções discricionárias da Administração Pública sejam explicitadas ao longo do processo administrativo. A autoridade pública, em seu agir, não poderá recortar os, fatos, fundamentos jurídicos, informações técnicas, dados e argumentos que justificariam a sua decisão a priori. A autoridade pública deverá considerar todos os

\footnotetext{
${ }^{452}$ O Processo Administrativo no Rol dos Direitos e Garantias Individuais, p. 132

${ }^{453}$ A expressão é de Diogo de Figueiredo MOREIRA NETO. Mutações do Direito Público, p. 332.

${ }^{454}$ Cf. Carlos Ari SUNDFELD. Importância do Procedimento Administrativo, p. 65-66.

${ }^{455}$ Como bem resumiu Sabino CASSESE: "ninguna decisión es one shot: esto es, ninguna decisión se agota em um solo acto.". Las Bases Del Derecho Administrativo, p. 249.

${ }^{456}$ Cf. Marçal JUSTEN FILHO. Ampla Defesa e Conhecimento de Argüições de Inconstitucionalidade e Legalidade no Processo Administrativo, p. 74.
} 
elementos trazidos ao processo administrativo em sua decisão e analisá-los objetivamente, ainda que seja para refutá-los e decidir em sentido contrário ao que aportam.

Odete MEDAUAR transporta essas noções à prática e observa que o processo administrativo possibilita o conhecimento da formação da decisão administrativa e, pois, constitui-se em requisito de validade desta.

"Na concepção atual, o processo administrativo configura meio de atendimento de requisitos de validade do ato administrativo. Além disso, propicia o conhecimento do que ocorre antes que o ato faça repercutir, sobre os indivíduos, os seus efeitos, permitindo verificar, por conseguinte, como se realiza a tomada de decisões; e assim contribui para conferir-lhe maior grau de objetividade. Como contraponto á visão estática da atividade administrativa, corresponde à noção atomista do ato, se tem a visão dinâmica, pois se focaliza o ato no seu 'formar-se' e nos seus vínculos instrumentais". ${ }^{457}$ (grifos nossos)

O processo administrativo figura, assim, em última análise, como condição de validade do ato administrativo e possibilita aos interessados e ao Poder Judiciário o acompanhamento e controle das decisões estatais. ${ }^{458}$

Não há dúvida de que a tomada de decisões administrativas, especialmente as discricionárias, por meio do processo administrativo torna factível o controle da discricionariedade do agente estatal. Isso porque o processo administrativo instrumentaliza a tomada de decisões da autoridade pública e impõe-lhe atuar com transparência e justificar suas razões em cada passo do processo decisório. Ao mesmo tempo, possibilita não só a participação dos interessados no processo decisório, mas também, o acompanhamento da formação da decisão administrativa por estes e por aqueles que detenham competência para o seu controle, tal qual o Poder Judiciário. Em síntese, o processo administrativo torna os juízos de discricionariedade visíveis e, pois, possibilitam o seu controle.

A esse respeito Marco Aurélio GRECO bem assevera que:

\footnotetext{
${ }^{457}$ O Direito Administrativo em Evolução, p. 224.

458 Esse é também o entendimento de Marçal JUSTEN FILHO. Curso de Direito administrativo, p. 235 e ss.
} 
"Em tema de controle o procedimento exerce grande importância, pois na medida em que são fixadas seqüências comportamentais obrigatórias, o interessado poderá constatar a exatidão das inúmeras etapas e diagnosticar o momento e o alcance de qualquer desvio." 459

Sob o enfoque do acompanhamento e controle das decisões estatais, o processo administrativo apresenta-se relevante em muitas outras facetas que podemos somar a essa asseverada por Marco Aurélio GRECO.

Odete MEDAUAR elenca as finalidades do processo administrativo e, assim, indiretamente nos expõe a importância do processo administrativo para o acompanhamento da formação da decisão administrativa e seu controle.

Aponta, pois, a autora como finalidades do processo administrativo: (i) a garantia dos administrados ${ }^{460}$; (ii) o melhor conteúdo das decisões, em decorrência da participação dos interessados ao longo do processo decisório; (iii) a legitimação do poder estatal, por meio da tomada explícita e fundamentada da decisão administrativa; (iv) o correto desempenho da função, na medida em que os interessados podem aportar ao processo administrativo as informações, argumentos, provas e dados de toda espécie, que devem ser ponderados para a tomada da decisão; (v) a justiça na Administração Pública, refletida no sopesamento dos vários interesses envolvidos; (vi) a aproximação entre a Administração Pública e os administrados em razão da colaboração processual que se estabelece; (vii) a sistematização das atuações administrativas em razão da organização racional dos atos administrativos; e (viii) a facilitação do controle da Administração Pública.

De fato, atingidas as finalidades expostas nos itens (ii) a (vii) possibilita-se o controle de outros momentos do processo decisório e não apenas do seu resultado final. ${ }^{461}$

\footnotetext{
${ }^{459}$ Dinâmica da Tributação e Procedimento, p. 98.

${ }^{460}$ Egon Bockmann MOREIRA tratou especificamente do tema. Para o autor o processo administrativo consagra-se como um direito-garantia dos administrados, conquanto uma realidade jurídica a integrar a esfera individual desses, sem ser necessariamente na defesa de algum direito ofendido. Processo Administrativo no Rol dos Direitos e Garantias Individuais, p. 126 e ss.

${ }^{461}$ Cf. Vasco Pereira da SILVA. Para um Contencioso Administrativo dos Particulares, p. 151.
} 
Além disso, o processo administrativo presta-se ao aperfeiçoamento da ação estatal, conquanto vislumbre-se que a decisão administrativa será resultado lógico dos eventos verificados no seu decorrer. A dialética processual teria o condão de impedir, desta feita, a prevalência de uma visão limitada e parcial dos fatos e o contraditório restringiria o risco da consagração de atitudes precipitadas e impulsivas. ${ }^{462}$

Nas palavras de Carlos Ari SUNDFELD, o processo administrativo "garante que a vontade funcional, que se expressará no ato, não seja empolgada pela vontade do agente, mas signifique uma vontade equilibrada, esclarecida, racional e imparcial. Em suma, assegura que o agente não se transforme em fim, mas guarde seu papel de mero intermediário [na tomada de decisões estatais]." O processo assegura, enfim, a eficiência estatal contra o próprio agente. ${ }^{463}$

Por tudo isso, o processo administrativo mostra-se imprescindível, hodiernamente, para o direito-garantia ${ }^{464} \mathrm{dos}$ administrados em face das decisões discricionárias da Administração Pública que os salvaguarda do eventual arbítrio dos agentes estatais. ${ }^{465}$

Frise-se que essas lições têm especial relevo em se tratando do processo administrativo que suporta as decisões discricionárias da Administração Pública, em que como vimos oportunamente no Capítulo I, há menor grau de vinculação à juridicidade. É que na hipótese em que há alguma margem de autonomia decisória para o agente estatal, o processo administrativo destina-se a "reduzir a complexidade do mundo real e traduzi-la em racionalidade jurídica e comunicacional". 466

Nesse sentido, o processo administrativo revela-se, ademais, como uma garantia democrática, na medida em que propicia a solução mais adequada ao caso concreto. Nas palavras de Marçal JUSTEN FILHO:

\footnotetext{
${ }^{462}$ Cf. Marcal JUSTEN FILHO. Curso de Direito Administrativo, p. 239.

${ }^{463}$ Importância do Procedimento Administrativo, p. 67.

${ }^{464}$ A expressão é de Egon Bockamann MOREIRA. Processo Administrativo no Rol dos Direitos e Garantias Individuais, p. 126 e ss.

${ }^{465}$ Eduardo García de ENTERRÍA e Tomás-Ramón FERNÁNDEZ observam no contexto das garantias dos administrados no Estado de Direito que "el procedimiento administrativo es la promera de esas garantias em tanto que supone que la actividad de la Administración tiene que canalizarse obligadamente a través de unos cauces determinados como requisito mínimo para que pueda ser calificada de legítima." Curso de Direito Administrativo, p. 381-382.

${ }^{466}$ Cf. Marcal JUSTEN FILHO. Curso de Direito Administrativo, p. 240.
} 


\begin{abstract}
"Por meio da procedimentalização, torna-se factível à autoridade administrativa evidenciar que sua escolha reflete a melhor alternativa possivel. A legitimidade da escolha da autoridade administrativa funda-se na existência do procedimento, por meio do qual se objetivaram as diversas alternativas teoricamente possíveis, examinaram-se suas vantagens e desvantagens $e$ se produziu uma escolha. A escolha da autoridade administrativa é satisfatória $e$ insuscetível a críticas, não porque a norma criou discricionariedade, mas porque, existindo competência discricionária, foi ela exercitada adequadamente. E $\underline{o}$ exercício adequado da discricionariedade pressupõe a observância de um procedimento destinado a apurar a solução mais correta e satisfatória para o caso." ${ }^{467}$ (grifos nossos)
\end{abstract}

Em conseqüência, o jurista afirma que a ausência de processo administrativo importa na invalidade da decisão administrativa, vez que essa passa a fundar-se apenas na afirmativa do agente estatal, "o que é insuscetível de fundar a validade jurídica numa democracia republicana". 468

O processo administrativo é, pois, instrumento democrático de racionalização jurídica das decisões administrativas. ${ }^{469}$

Vimos, assim, ao longo desse item, quatro das mais relevantes feições do processo administrativo (i) como condição de legitimidade das ações estatais; (ii) como condição de validade das decisões administrativas; (iii) como direito-garantia dos administrados; e (iv) como instrumento democrático de racionalização das decisões administrativas.

Essas feições, per se, conferem ao processo administrativo a qualidade de pressuposto do ensaio apresentado a seguir sobre parâmetros concretos e objetivos para o acompanhamento e controle das decisões regulatórias discricionárias. É dizer, ausente o

${ }^{467}$ Curso de Direito Administrativo, p. 240.

${ }^{468}$ Cf. Marçal JUSTEN FILHO. Curso de Direito Administrativo, p. 241.

469 Os processos administrativos - conquanto expressão de racionalização jurídica - são pautados por uma série de princípios. Não há uniformidade na doutrina acerca de sua classificação. Para um panorama sistemático e completo ver, por todos, Princípios do Processo Administrativo. Floriano de Azevedo MARQUES NETO. 
processo administrativo e, pois, inexistente o mecanismos formal de legitimidade, validade e racionalização das decisões estatais e, por conseguinte, violado o direito-garantia dos administrados ao processo administrativo, inexistiria a base para a propositura do aprimoramento das decisões regulatórias discricionárias.

A ANATEL, como vimos na PARTE II, Capítulo III da dissertação, deve atuar de maneira processualizada. Diversos são os trâmites processuais na Agência Reguladora. O pressuposto processual, como constatamos oportunamente, existe. Temos apenas que aprimorar essa base para que os processos decisórios da ANATEL atinjam suas finalidades e encerrem a racionalização das decisões regulatórias discricionárias.

É com esse fim que passamos a apresentar nossos parâmetros para o acompanhamento e controle das decisões discricionárias da Agência Reguladora.

\section{5. Parâmetros de Aferição Casuística da Melhor Solução Juridicamente Possível.}

Apresentaremos a seguir os parâmetros concretos e objetivos que acreditamos permitir a aferição, em cada caso concreto, da correção e da adequação das decisões regulatórias da ANATEL e, bem assim, da adoção ou não da "melhor solução juridicamente possível" pelo regulador.

Acreditamos que os critérios expostos adiante contribuem para identificar as decisões regulatórias discricionárias arbitrárias em que o desvio de poder do regulador se oculta e, por conseguinte, para inibir o arbítrio e fortalecer o controle da ANATEL pelos interessados e pelo Poder Judiciário.

Quatro foram os parâmetros que cunhamos com vistas a essa finalidade: (i) $a$ vinculação aos precedentes da ANATEL; (ii) a motivação positiva e negativa de todos os atos do processo decisório; (iii) a transparência do processo decisório; e (iv) a efetividade e o prognóstico da efetividade das decisões regulatórias discricionárias.

A aplicação desses parâmetros possibilitaria constatar se o regulador produziu a "melhor solução juridicamente possível” no caso concreto, na medida em que, como já tivemos a oportunidade de afirmar, permitiria aferir se além de cumprir com todos os requisitos de legalidade, a decisão regulatória discricionária mostrou-se resultante de 
amplo e transparente processo decisório, fruto de diálogo e confrontação racional entre os interessados e entre esses e a ANATEL, deferente aos precedentes da Agência Reguladora, motivada positiva e negativamente e se proporcionou, senão à compatibilização ótima de todos os interesses envolvidos, o equilíbrio ideal entre o interesse satisfeito e o interesse sacrificado

A concepção desses parâmetros teve como diretriz duas noções basilares, o pragmatismo da hard look doctrine e a hermenêutica da razão pública.

A contribuição do pragmatismo do hard look doctrine d70 $^{470}$ nossa proposta evidencia-se na expressão dos parâmetros apresentados em testes destinados a real verificação de seus elementos caso a caso.

O aporte realizado pela razão pública ${ }^{471} \mathrm{em}$ nossa proposta diz com a sua utilização como ferramenta hermenêutica e $\operatorname{argumentativa~}^{472}$ ao longo dos testes propostos,

${ }^{470}$ Ver sobre o tema: Sérgio Varella BRUNA Agências Reguladoras: Poder Normativo, Consulta Pública, Revisão Judicial. Thomas J. MILES e Cass SUNSTEIN. The Real Word of Arbitrariness Review. 75 U. Chi. L. Review. 761, 772. 20081 Notes: Rationalizing Hard Look Review After the Fact. 122 Harvard Law Review. 1909, 2008/2009, p. 1909-1930. Deregulation and the Hard Look Doctrine. Cass R. SUNSTEIN. Sup. Ct. Rev.177, 1983, p. 177-213. Considering Political Alternatives to 'Hard Look Doctrine'. Peter L. STRAUS. Duke L. J. 538, 1989, p. 538-550. A Hard Look at Hard Cases: The Nightmare of a Noble Dreamer. Allan C. HUTCHINSON e John N. WAKEFIELD. Oxford J. Legal Study. 86, 1982, p. 86-110. FCC v. Fox Television Stations and the Role of Logical Error in Hard Look Review. Samuel G. BROOKS. BYU L. Review. 687. 2010, p. 687-717.

${ }^{471}$ A expressão é de KANT, mas só ganhou projeção graças à obra de John RAWLS. A expressão aparece no livro O Liberalismo Político de 1993. Como resultado de duas conferências oferecidas na Universidade da Califórnia em 1990. Posteriormente, no livro O Direito dos Povos, John RAWLS reapresenta a idéia com algumas alterações. A teoria de John RAWLS sobre a razão pública, embora seja a mais famosa, não é a única e não é aceita sem contestações. Cf. José Vicente Santos de Mendonça. A Captura Democrática da Constituição Econômica: uma proposta de releitura das atividades públicas de fomento, disciplina e intervenção direta na economia à luz do pragmatismo e da razão pública, p. 150 e ss. A teoria de John RAWLS parte do fato do pluralismo constituído pela coexistência de uma série de doutrinas abrangentes razoáveis e concluí que todas essas não podem estar inteiramente certas ao mesmo tempo, o que excluída a hipótese de força para a garantia de um vencedor vai impor a necessidade de um consenso entre as diversas visões de mundo. Busca-se, então, o consenso político fixado na noção de justiça, é o consenso sobreposto às razões morais, religiosas e filosóficas, que irá, assim, constituir a base para a estabilidade das relações. Ressalve-se que a teoria de John RAWLS é pensada no contexto da common law e do debate constitucional americano. O Liberalismo Político, p. 104 e ss.

472 A razão pública conquanto ferramenta hermenêutica funciona, como sustenta José Vicente Santos de MENDONÇA, como um filtro a respeito de quais razões poderão orientar o debate público numa sociedade que tenha aderido ao consenso. A razão pública, nesse sentido, é a forma de se argumentar publicamente na sociedade democrática e que deve orientar a conduta dos agentes públicos e dos particulares. Para o autor "[o] conteúdo da razão pública é na essência o de um dever de reciprocidade: as razões apresentadas por uma pessoa só podem ser aquelas que ela própria razoavelmente aceitaria, e que ela esperaria de boa-fé que outra pessoa razoavelmente aceitasse." A Captura Democrática da Constituição Econômica: uma proposta de releitura das atividades públicas de fomento, disciplina e intervenção direta na economia à luz do pragmatismo e da razão pública. Tese de Doutorado. Universidade do Estado do Rio de Janeiro. 2010, p. 155. 
de modo que essa seja imperativa na construção da decisão regulatória discricionária e na relação jurídica estabelecida entre a ANATEL e os interessados.

Veja-se que se tratam de testes cumulativos e não alternativos, isto é, a realização de um deles não exclui a dos demais, ainda que seu resultado seja positivo. A melhor solução juridicamente possível produzida pelo regulador implica em que os quatro testes propostos sejam ultrapassados positivamente. A negativa em qualquer um deles evidencia que há risco de que a decisão regulatória discricionária pode ter sido arbitrária e, portanto, enseja maiores investigações dos interessados e dos órgãos de fiscalização para averiguar, mais a fundo, os caminhos adotados pelo regulador no caso concreto.

Alertamos, por fim, que os parâmetros propostos não são exclusivos, isto é, não afastam a aplicação de outros critérios ou mecanismos de aferição da correção das decisões discricionárias regulatórias. Reconhecemos que muitos outros instrumentos podem ser agregados à proposta que ora apresentamos.

\section{5. 1. A Vinculação aos Precedentes da ANATEL.}

$\mathrm{O}$ primeiro parâmetro concreto e objetivo que propomos para o acompanhamento pelos interessados dos processos decisórios da ANATEL e para a eventual confrontação das decisões regulatórias discricionárias desses decorrentes é o teste da vinculação da ANATEL aos seus próprios precedentes.

Essa proposta tem lugar na concepção de que os sistemas da common law e da civil law constituem dois aspectos de uma mesma e grande tradição jurídica ocidental. ${ }^{473}$

A adoção da vinculação aos próprios precedentes justifica-se, ademais, na medida em que a lei, em nosso sistema romanístico, revelou-se insuficiente no Estado Contemporâneo para proporcionar igualdade, coerência, estabilidade, previsibilidade e, portanto, segurança jurídica, aos administrados.

Como vimos na PARTE I, Capítulo I da dissertação, essa insuficiência deveuse principalmente ao reconhecimento e a necessária mediação ativa de múltiplos interesses legítimos e à renovada relação entre legalidade e discricionariedade em um contexto de policentrismo estatal.

\footnotetext{
${ }^{473}$ Cf. Luiz Guilherme MARINONI. Precedentes Obrigatórios, p. 17.
} 
Luiz Guilherme MARINONI assim apreendeu o que queremos dizer:

"A ausência de respeito aos precedentes está fundada na falsa suposição, própria do civil law, de que a lei seria suficiente para garantir a certeza e a segurança jurídicas. A tradição de civil law afirmou a tese de que a segurança jurídica apenas seria viável se a lei fosse estritamente aplicada. A segurança seria garantida mediante a certeza advinda da subordinação do juiz à lei. (...). Contudo, nem ao se 'descobrir' que a lei é interpretada de diversas formas, e, mais visivelmente, que os juízes do civil law rotineiramente decidem de diferentes modos os 'casos iguais', abandonouse a suposição de que a lei é suficiente para garantir a segurança jurídica." ${ }^{474}$ (grifos nossos)

Essas ponderações realizadas para o âmbito judicial, certamente, podem ser transportadas para o ambiente das Agências Reguladoras, em que não só a lei, mas a regulamentação (e especialmente a regulamentação, na medida em que não é clara, objetiva e precisa), não confere segurança jurídica aos regulados e, mais que isso, em que os órgãos colegiados desses entes, por diversas razões, da mesma forma, não lhes consegue provê-la.

Especificamente acerca do setor de telecomunicações, o que se evidencia é a existência de uma legislação necessariamente vetorial e uma regulamentação densa e complexa, mas que muitas vezes é aberta e, pois, não complementa e encerra as diretivas legislativas. Esse quadro remete-nos, por conseguinte, inúmeras vezes, a sujeição ao critério discricionário dos conselheiros da ANATEL.

Diante desse cenário, a autovinculação aos precedentes apresenta-se como importante instrumento de racionalidade das decisões regulatórias discricionárias e prestase a assegurar a igualdade entre os regulados perante a ANATEL, promover a coerência da ordem jurídica, propiciar estabilidade nas relações entre esse ente e os agentes de mercado e usuários de serviços e a previsibilidade das decisões regulatórias discricionárias. Essa é a segurança jurídica que inexiste, nos dias atuais, no relacionamento entre a ANATEL e os agentes do mercado de telecomunicações, com efeitos diretos e indiretos, nos usuários

\footnotetext{
${ }^{474}$ Precedentes Obrigatórios, p. 19.
} 
potenciais e efetivos desses serviços e mercados adjacentes; como vimos no Capítulo III, o setor de telecomunicações ainda é um setor de risco.

O parâmetro proposto decorre, assim, da integração de elementos da common law e da civil law, especialmente da Teoria do Precedente ${ }^{475}$ (stare decisiset non quieta mover $^{476}$ ) do direito anglo-saxão com a autolimitação aos precedentes da Teoria da Autolimitação Administrativa, do direito romano-germânico. ${ }^{477}$

Anote-se, em tempo, que ambas as teorias se referem à vinculação aos próprios precedentes no âmbito do Poder Judiciário, tal como exporemos a seguir. Contudo, transportaremos as principais idéias desses parâmetros decisórios para o âmbito das Agências Reguladoras e, especificamente da ANATEL, tal como já fizemos acima.

É preciso, então, conhecer as bases do parâmetro ora proposto.

A Teoria do Precedente (stare decissis) é o alicerce do direito anglo-saxão ${ }^{478} \mathrm{e}$ é com base nesta que o Direito é pensado, aplicado, discutido e desenvolvido nos países que adotam o sistema da commom law. ${ }^{479}$

Não se trata de um comando inexorável, mas de um princípio que deve ser levado em consideração na resolução de casos que apresentem semelhanças de fatos e de questões de direito quando comparados a casos anteriormente julgados. ${ }^{480}$

No sistema da common law, como expõe Edward D. RE, as decisões judiciais desempenham dupla função. A decisão, em primeiro lugar, define a controvérsia e, em

\footnotetext{
${ }^{475}$ Para conhecer em detalhes a Teoria dos Precedentes recomendamos entrenós, a excelente obra de Luiz Guilherme MARINONI. Precedentes Obrigatórios.

${ }^{476}$ É dizer "mantenha-se a decisão e não se disturbe o que foi decidido". Edward D. RE. Stare Decisis, p. 37.

${ }^{477}$ Para um panorama da influência no Direito Administrativo brasileiro pelos sistemas romanístico e de common law ver Maria Sylvia Zanella DI PIETRO. O Direito Administrativo Brasileiro sob Influência dos Sistemas de Base Romanística e da Common Law. Anote-se, ademais, que a vinculação aos precedentes é também um dos elementos basilares da Teoria Geral da Argumentação Jurídica de Robert ALEXY. Teoria dos Direitos Fundamentais, p. 548 e ss.

${ }^{478}$ Especialmente entre a doutrina do precedente nos Estados Unidos e na Inglaterra existem pequenas diferenças, embora a primeira tenha se originado da segunda. A doutrina norte-americana é conhecida como liberal e a inglesa como restritiva. A esse respeito ver Cf. Peter J. MESSITE. O Papel do Precedente no Direito Norte Americano e Luis Renato Ferreira da SILVA. A Regra do Precedente no Direito Inglês.

${ }^{479}$ Veja-se, no entanto, que a natureza da common law não se explica meramente através do stare decisis, uma vez que "a elaboração de regras e princípios regulando o uso de precedentes e a determinação $e$ aceitação de sua autoridade são relativamente recentes, para não se falar da noção de precedentes vinculantes (binding precedentes), que é mais recente ainda." Em contraposição ao fato de que o common law nasceu séculos antes.Cf. Luiz Guilherme MARINONI. Precedentes Obrigatórios, p. 33.

${ }^{480}$ Cf. Tássia Baia MIRANDA. Stare Decisis e a Aplicação do Precedente no Sistema Norte-Americano, p. 265 .
} 
segundo lugar, consoante a doutrina do stare decisis, constitui precedente para os casos futuros. $^{481}$

A Teoria do Precedente estabelece que "havendo uma corte formulado um princípio jurídico como aplicável a um determinado conjunto de fatos, ela seguirá esse princípio, aplicando-o aos casos futuros que apresentem substancialmente os mesmos fatos" ${ }^{482}$ e, no mesmo sentido, vinculará as decisões dos tribunais de instância inferior pertencentes a mesma jurisdição. ${ }^{483}$

É dizer que os tribunais de instâncias inferiores estarão vinculados pelo precedente de um tribunal de instância superior somente quando ambos estiverem situados em uma mesma linha hierárquica. Assim, por exemplo, as decisões da Suprema Corte norte-americana sobre questões de natureza constitucional vincularão todos os tribunais norte-americanos, em nível federal e estadual. ${ }^{484}$

Não é, todavia, a integralidade da decisão do tribunal de instância superior que tem o condão de vincular as decisões das demais cortes que lhe são hierarquicamente inferiores, mas apenas a parte mais central da sentença. Isto é, somente o princípio legal, ou a ratio decidendi, que era absolutamente necessária para decidir a questão do caso concreto tem força vinculante e, somente essa, pode ser extraída e utilizada nos casos concretos subsequentes ${ }^{485}$ que apresentem semelhança factual e de questões jurídicas com o leading case.

Todo o dito pelos juízes em seus julgados, que não tenha relação direta com a decisão tomada, ou que não tenha se mostrado essencial para o proferimento da decisão, é chamado de dictum (ou obter dictum) e não possui caráter vinculante, podendo apenas ser considerado como elemento persuasivo nos casos futuros. ${ }^{486}$

Os precedentes não são necessariamente vinculativos, isto é, existem situações em que a regra do precedente é flexível. Em suma, os Tribunais podem se recusar a aplicar

\footnotetext{
${ }^{481}$ Stare Decisis, p. 56.

${ }^{482}$ Cf. Donald J. DUNN e Roy M. MERSKY. Legal Research Illustrated. An Abridgment of Fundamentals of Legal Research, p. XXXV. Tradução nossa.

483 Cf. Mauro CAPPLLETTI. O Controle Judicial de Constitucionalidade das Leis no Direito Comparado, p. 80.

${ }^{484}$ Cf. Peter J. MESSITE. O Papel do Precedente no Direito Norte Americano, p. 91.

${ }^{485}$ Cf. Peter J. MESSITE. O Papel do Precedente no Direito Norte Americano, p. 92.

${ }^{486}$ Cf. Tássia Baia MIRANDA. Stare Decisis e a Aplicação do Precedente no Sistema Norte-Americano, p. 265.
} 
um precedente se: (i) o precedente envolver uma questão de direito distinta, (ii) o escopo do precedente for tão limitado que não se aplique ao caso em pauta e (iii) os fatos do precedente forem distintos daqueles a que se refere o caso atual ou, ainda, rejeitar o precedente porque o princípio nele contido deve ser revogado ou porque reflete a dicta e não a ratio do julgador anterior. ${ }^{487}$

O processo de verificação de aplicação do precedente ao caso concreto em exame, como anota Elival da Silva RAMOS, consiste, assim, primeiro na verificação do julgado diante do caso que é trazido a julgamento, pois se pode entender que a norma dele inferida não é aplicável à controvérsia atual, em razão de diferenças relevantes nos fatos (a técnica do distinguishing); em segundo lugar, procede-se ao refinamento da interpretação do texto da decisão precedente, do que poderá resultar a restrição ou ampliação dos efeitos da norma a ele acoplada ou até mesmo o reconhecimento da revogação, total ou parcial, do precedente (a técnica do overruling) ${ }^{488}$; finalmente, na hipótese de se constatar a imprestabilidade do precedente para o caso sub judice, o juiz ou o tribunal produzirão a norma de decisão com base nos princípios da common law. ${ }^{489}$

Por fim, cumpre-nos registrar que a doutrina aponta as razões para a existência e manutenção da Teoria do Precedente, as mais correntes são (i) a igualdade no provimento jurisdicional $^{490}$, (ii) a previsibilidade do provimento judicial, (iii) a economia judicial e (iv) o respeito por decisões anteriores. ${ }^{491}$

${ }^{487}$ Cf. Toni M. FINE. O Uso do Precedente e o Papel do Princípio do Stare Decisis no Sistema Legal Norte-Americano, p. 92.

${ }^{488}$ Veja-se, entretanto, que a revogação de precedentes não é freqüente; ao contrário, é evitada no sistema da common law. Isso porque nesse se tem a crença na profunda consistência, integridade e segurança nos precedentes. Cf. Peter J. MESSITE. O Papel do Precedente no Direito Norte Americano, p. 93-94. Nesse sentido, Tássia MIRANDA assevera que "Deve o juiz atuar como membro de uma comunidade constituída por julgadores que exercem seus ofícios construindo posições jurídicas formadoras de uma instituição, o Judiciário. Já que é necessária coesão na interpretação, análise e abrangência dos direitos, o respeito por decisões anteriores gera jurisprudência livre de dúvidas e insegurança. Sob a ótica da construção do direito através do respeito pelas decisões alicerçadas no passado, é imprescindível o olhar do magistrado para toda uma tradição e corrente de pensamentos construídos durante séculos pelos seus antecessores. (...) Conspiram esses elementos para a manutenção de uma substancial uniformidade nas decisões judiciais, ferramenta indispensável na busca por previsibilidade, facilitação da administração do direito público, promoção da equidade e visão do Judiciário como autoridade de voz uma e harmônica.". Stare Decisis e a Aplicação do Precedente no Sistema Norte-Americano, p. 269.

${ }^{489}$ Ativismo Judicial: Parâmetros Dogmáticos, p. 106.

${ }^{490}$ Note-se que não se trata aqui de igualdade ao acesso ao Poder Judiciário ou igualdade no processo, mas igualdade nas decisões judiciais.

${ }^{491}$ Aponta-se, também, ademais: a justiça da decisão, o fortalecimento do processo decisório, a eficiência do processo decisório 
Essas razões são, assim, explicadas pelo juiz da Corte Federal do Distrito de Maryland, Estados Unidos, Peter J. MESSITE:

“a) aplicar a mesma regra em casos análogos e subsequentes resulta em igualdade no tratamento de todos os que buscam justiça.

b) saber que o caso subseqüente será decidido de maneira consistente a um caso anterior contribui para a antecipação, permite a visualização prévia e resolve muito do possível futuro litígio.

c) o uso do critério estabelecido para a solução dos casos economiza tempo e energia.

d) a aderência ás decisões anteriores demonstra um respeito bastante apropriado à sabedoria e à experiência dos advogados e juízes que vieram primeiro." 492

A essas agregamos ainda a racionalidade da decisão nos termos sustentados por Luiz Guilherme MARINONI. ${ }^{493}$

Com efeito, são esses mesmo valores buscados pela Teoria da Autolimitação Administrativa, como veremos adiante.

Apresentadas, assim, as linhas gerais da Teoria do Precedente, passamos a expor a Teoria da Autolimitação Administrativa.

A idéia de vinculação da ANATEL aos seus próprios precedentes não é de todo uma novidade no Direito pátrio, em que se iniciam os estudos doutrinários e se introduz também nos tribunais ${ }^{494}$ a Teoria da Autolimitação Administrativa.

Cabe-nos, desta feita, apresentá-la e, desde já, observar que, em linhas gerais, muito se assemelha a Teoria do Precedente da common law. ${ }^{495}$

\footnotetext{
${ }^{492}$ O Papel do Precedente no Direito Norte-Americano, p. 95-96.

${ }^{493}$ Precedentes Obrigatórios, p. 145.

494 A esse respeito ver as ementas destacadas por Alexandre Santos de ARAGÃO em seu Teoria das Autolimitações Administrativas: Atos Próprios, Confiança Legítima e Contradição entre Órgãos Administrativos, p. 8-9.

${ }^{495}$ Sobre o tema ver Princípio da Boa Fé e Decisão Administrativa de Pedro Moniz Lopes.
} 
A Teoria da Autolimitação Administrativa, em linhas gerais, obsta que a Administração Pública adote entendimentos contrários ou desconformes aos precedentes ${ }^{496}$ preestabelecidos diante dos mesmos fatos. ${ }^{497}$ Nesse aspecto, a autovinculação administrativa é um instrumento de redução da discricionariedade estatal no âmbito dos atos concretos da Administração Pública que possibilidade impedir atuações caprichosas dos agentes públicos ou alterações repentinas em seu padrão decisório. ${ }^{498}$

A Teoria da Autolimitação Administrativa é decorrência da contemporânea relação jurídica entre a Administração Pública e os administrados, em que a estes últimos se apresentam instrumentos para a salvaguarda de seus direitos e interesses em face do agir administrativo, especialmente discricionário.

O seu surgimento, como anota Paulo MODESTO, deve-se a uma nova abordagem sobre a situação do administrado diante da adoção reiterada de um dado decidir ou agir administrativo, ou interpretar disposições jurídicas, em casos concretos, ao longo do tempo, fixando um padrão decisório que lhe suscita confiança. Mas que diante de novo caso concreto, o administrativo assiste o abandono do padrão decisório reiterado, no passado, pela Administração Pública, sem motivação que apresentem as razões da mudança em seus critérios de atuação. ${ }^{499}$

Impõe-se, assim, nestes casos, para a observância dos princípios da igualdade, boa-fé e segurança jurídica ${ }^{500}$, que o mesmo padrão decisório seja adotado nas situações futuras que envolvam fatos, senão idênticos, similares àqueles objetos de decisões reiteradas da Administração Pública, salvo justificativa fundada em alteração das circunstâncias e necessidade de reformar o posicionamento padrão anterior em face do interesse público. ${ }^{501}$

\footnotetext{
${ }^{496}$ Os precedentes são apenas uma das formas de autolimitação administrativas. Dentre essas se identificam também a vinculação aos próprios atos, à práxis administrativa e o cumprimento de seus próprios regulamentos. Especificamente com relação a vinculação aos precedentes e aos atos próprios a doutrina administrativista não é unânime acerca de sua diferenciação. A diferença estaria no fato de que a primeira envolveria interessados para além do titular do caso precedente e na segunda envolveria apenas o titular do embate com a Administração Pública. Não vemos relevância nessa diferenciação, tal como Alexandre Santos de ARAGÃo. Teoria das Autolimitações Administrativas: Atos Próprios, Confiança Legítima e Contradição entre Órgãos Administrativos, p. 4.

${ }_{497}$ Cf. Alexandre Santos ARAGÃO. Teoria das Autolimitações Administrativas: Atos Próprios, Confiança Legítima e Contradição entre Órgãos Administrativos, p. 1.

${ }^{498}$ Cf. Paulo MODESTO. Autovinculação da Administração Pública, p. 9-10.

${ }^{499}$ Autovinculação da Administração Pública, p. 10.

${ }^{500}$ Acerca dos princípios da boa-fé e segurança jurídica ver o item V. 2 precedente.

${ }^{501}$ Cf. Paulo MODESTO. Autovinculação da Administração Pública, p. 10.
} 
Nas exatas palavras de Paulo MODESTO:

"A Administração Pública, como regra, portanto, mesmo
diante de competência aparentemente discricionária, deve
considerar-se 'autovinculada ao precedente', isto é,
predeterminada na escolha de uma decisão dentre as
possíveis no exercício de competência discricionária em
razão da reiterada adoção por ela mesma de um mesmo
padrão decisório." ${ }^{502}$ (grifos no original)

A Administração Pública estaria, assim, autovinculada a sua atuação precedente, em razão da reiteração de seus posicionamentos e decisões, que criariam um padrão decisório para casos assemelhados.

É nesse sentido à lição de José Ortiz DIAZ para quem “o administrador, diante de caso idêntico ao que foi por ele resolvido, no qual exerceu uma função interpretativa do Direito, deve ter em conta a maneira como atuou anteriormente para não dar aplicações completamente distintas e para manter o princípio da igualdade entre os cidadãos frente à lei, no que de certo modo poderia ser chamado de igualdade na interpretação da norma jurídica" ${ }^{503} \mathrm{E}$, bem assim, o ensinamento de Jesús González PÉREZ, segundo o qual “como projeção do princípio da igualdade se tem considerado o princípio que proíbe ir contra os próprios atos. Se o que aquele comporta é um igual tratamento de situações iguais, é inquestionável que, havendo atuado a Administração, diante de uma situação, em um determinado sentido, não lhe será lícito fazê-lo de outra forma, diante da mesma situação.” 504

É que a Administração Pública tem o dever de coerência no decidir que consiste na necessidade de observar no futuro a conduta com que os atos anteriores faziam prever. ${ }^{505}$ Como bem explica Sérgio FERRAZ, "[t]rata-se de imperativo lógico (a disparidade corrói a confiabilidade do sistema) e principiológico (a segurança jurídica não convive com a leviandade nas decisões). Em suma, as decisões administrativas devem

\footnotetext{
${ }^{502}$ Cf. Paulo MODESTO. Autovinculação da Administração Pública, p. 10.

${ }^{503}$ El Precedente Administrativo, p. 86.

${ }^{504}$ El Principio General de la Buena Fe en el Derecho Administrativo, p. 122.

505 A expressão é de Alexandre Santos de ARAGÃO. Teoria das Autolimitações Administrativas: Atos Próprios, Confiança Legítima e Contradição entre Órgãos Administrativos, p. 2-3.
} 
guardar um mínimo de coerência, não se admitindo, por isso, tratamento, diferenciado para hipóteses idênticas ou muito assemelhadas." 506

Luiz Ma DÍEZ-PICAZO identifica no agir administrativo desvinculado de seus próprios precedentes um vício de causa do ato administrativo. ${ }^{507}$ Jesús GONZÁLEZ PÉREZ afirma que diante de atuação contraditória da Administração Pública em face de sua própria conduta anterior vinculante o Princípio dos Atos Próprios determinará a invalidade do ato administrativo e serviria de fundamento da pretensão que se deduza contra este. $^{508}$

A autovinculação administrativa aos seus próprios precedentes constituir-se-ia, assim, em mecanismos que visa a assegurar, ao mesmo tempo, a igualdade de tratamento entre os administrados, a razoabilidade das decisões administrativas e a coerência da Administração Pública.

A Administração Pública, entretanto, não está impedida de alterar os seus posicionamentos (ou o seu padrão decisório). Mas se nesse sentido agir deve motivar a mudança de rota, justificar não apenas a decisão concreta, mas a própria alteração de critério decisório, afastando qualquer suspeita de atuação caprichosa ou contrária aos padrões éticos da boa-fé. ${ }^{509}$

O que propomos, então, aplicando as lições da Teoria do Precedente e da Teoria das Autolimitações Administrativas à realidade da ANATEL, é que a Agência Reguladora atue de maneira vinculada aos seus próprios precedentes para a decisão de casos concretos análogos e assemelhados.

As decisões de caráter definitivo do Conselho Diretor da ANATEL (e somente essas $^{510}$ ) constituir-se-iam, assim, em precedentes vinculantes às decisões dos novos casos concretos submetidos ao crivo da Agência Reguladora. É dizer, nessa medida, que diante do julgamento de cada novo caso concreto, a ANATEL estaria obrigada a revisitar seus

\footnotetext{
${ }^{506}$ Processo Administrativo, p. 152.

${ }^{507}$ La Doctrina Del Precedente Administrativo, p. 39.

${ }^{508}$ El Principio General de la Buena Fe en el Derecho Administrativo, p. 209.

${ }^{509}$ Cf. Paulo MODESTO. Autovinculação da Administração Pública, p. 10. Anote-se que o dever de motivação decorre, inclusive, do art. 50, VII da Lei n. ${ }^{\circ}$ 9.784/1999. O tema da motivação será tratado em detalhes no item V. 5. 2 adiante.

${ }_{510}$ Afastam-se aqui, pois, decisões incidentais ou de que ainda caibam recursos e, bem assim, decisões das superintendências e gerências da ANATEL.
} 
próprios precedentes a fim de averiguar a sua aplicabilidade ou o seu afastamento no caso em exame, ambos de maneira absolutamente motivada, como veremos no item seguinte.

A regra seria, assim, a manutenção das decisões regulatórias discricionárias anteriores nos processos decisórios posteriores, de casos assemelhados em fatos e questões jurídicas e, a exceção, seria o afastamento dos precedentes da ANATEL. ${ }^{511}$ Essa regra, sem dúvida, contribuiria para a racionalidade ${ }^{512}$ das decisões regulatórias discricionárias da ANATEL, para a promoção da igualdade entre os regulados e para segurança jurídica das relações entre esses e a Agência Reguladora.

Anote-se que, tal qual, vimos anteriormente, não seria a integralidade dos precedentes que teria o condão de vincular as decisões discricionárias futuras da Agência Reguladora. Mas, tão-somente, o núcleo jurídico do precedente, imprescindível para a promoção da igualdade entre os regulados, coerência da ANATEL e estabilidade da relação entre essa e os interessados.

Lembre-se que, como constatamos em nosso estudo de casos na PARTE II, Capítulo III da dissertação, a ANATEL não ponderou - positiva ou negativamente - a aplicabilidade vinculativa de seus precedentes para a decisão dos casos concretos por ocasião em exame ${ }^{513}$. A Agência Reguladora não observou, ademais, qualquer padrão decisório, ao contrário, decidiu aleatoriamente e de maneira não isonômica. As decisões nos casos estudados eram e, de fato, assim se constatou, imprevisíveis.

Não temos dúvida, entretanto, de que a adoção da vinculação da ANATEL aos seus próprios precedentes como parâmetro concreto e objetivo de decisão da Agência Reguladora seria de grande importância, especialmente diante de casos concretos em que

${ }^{511}$ Robert ALEXY explícita as duas regras principais para a utilização dos precedentes: “(1) se é possível utilizar um precedente favorável ou contrário a uma decisão, ele deverá ser utilizado; e (2) aquele que pretende afastar o precedente tem o ônus argumentativo para tanto.”. Teoria dos Direitos Fundamentais, p. 556.

${ }_{512}$ Luiz Guilherme MARINONI anota que “[a] irracionalidade é ainda mais indisfarçável na decisão que se distância da decisão anterior, proferida pelo mesmo órgão jurisdicional em caso similar, ou melhor, em caso que exigiu a apreciação da questão jurídica, que o órgão prolator da decisão já definira." Precedentes Obrigatórios, p. 145.

513 Note-se que a aplicação injustificada dos mesmos condicionamentos e contrapartidas para casos não assemelhados, por vontade exclusiva do regulador, tal como ocorreu no caso Tlf-GVT não pode ser confundida com o parâmetro proposto. No caso estudado não se constatou a avaliação de aplicabilidade do precedente, ao contrário, a critério exclusivo de conselheiro da ANATEL, determinou-se sem qualquer motivação razoável, a adoção de parcela das medidas aplicadas no caso BrT-Oi, o que representou, em última análise, em tratamento não isonômico, haja vista que as operações apresentadas à ANATEL eram diferentes tal como os seus impactos no mercado de telecomunicações. 
se constatasse a possibilidade de exercício de sua discricionariedade no processo decisório e, mais ainda, diante de situações do manejo da discricionariedade na mediação ativa de interesses legítimos contrapostos, tal como os casos de anuência prévia em matéria de transferência de controle de operadoras de serviços de telecomunicações analisados na PARTE II, Capítulo III desta dissertação. Nesses casos, o dever de decidir de maneira isonômica entre as situações assemelhadas, presentes e passadas, submetidas à Agência Reguladora e a previsibilidade da decisão regulatória discricionária da ANATEL representariam importantes salvaguardas contra decisões subjetivas e arbitrárias dos seus conselheiros, conferindo segurança jurídica ao setor de telecomunicações e moldando a atuação dos agentes desse mercado.

Frisemos que a adoção da vinculação da Agência Reguladora aos seus próprios precedentes não significa, contudo, o engessamento dos processos decisórios da ANATEL, tampouco visa tolher a discricionariedade dos seus conselheiros. Implica, tão-somente, em obrigar que a Agência Reguladora decida de maneira coerente, coesa e isonômica os casos concretos que lhe são apresentados; de maneira que, diante do afastamento dos precedentes existentes, os conselheiros justifiquem, com riqueza de detalhes, as razões dessa decisão e, mais que isso, as apresente aos demais membros do colegiado para debate e, por conseguinte, propiciem que as decisões do Conselho Diretor da ANATEL sejam levadas a sério pelos regulados.

É importante destacar, ainda, que o parâmetro proposto não teria o condão de afastar as análises técnicas realizadas pelas gerências e superintendências da ANATEL; ao contrário, a atividade desempenhada por esses órgãos seriam relevantes para a fixação das semelhanças entre o caso concreto em exame e os precedentes da Agência Reguladora. É no âmbito das gerências e superintendências da ANATEL que se deveriam aportar os elementos que distinguirão ou comprovarão a aplicabilidade dos precedentes da Agência Reguladora por seus conselheiros.

Por fim, devemos atentar que a ANATEL, em seus mais de 14 anos de atuação, possui uma enorme gama de decisões (milhares) que atualmente constituem um emaranhado de precedentes sem qualquer organização lógica e de difícil acesso. ${ }^{514}$

\footnotetext{
${ }^{514}$ Sobre o tema da transparência da ANATEL falaremos no item V. 5. 3 mais a frente.
} 
A vinculação da ANATEL aos seus próprios precedentes pressupõe, todavia, que esses estejam disponíveis e acessíveis ao público em geral. Isso porque, como depreendemos das teorias expostas inicialmente, a vinculação aos próprios precedentes possui dupla finalidade: uma a de promover o tratamento isonômico entre todos os regulados; e, outra, a de conferir previsibilidade, estabilidade e segurança jurídica ao subsistema regulado.

O cumprimento desta última finalidade está, pois, condicionado a que os interessados conheçam os posicionamentos da ANATEL, de modo que moldem a sua atuação no mercado de telecomunicações de acordo com o padrão decisório da Agência Reguladora. Desta feita, parece-nos imprescindível que a ANATEL promova a catalogação de seus precedentes e, bem assim, os disponibilize, efetivamente, sem formalidades ao público em geral. Ao problema da transparência da Agência Reguladora voltaremos no item V. 5. 3.

Não temos dúvidas, em conclusão, de que a adoção da vinculação da ANATEL aos próprios precedentes seria absolutamente benéfica não só para o acompanhamento das decisões regulatórias pelos interessados e para o seu controle judicial, mas também para balizar a atuação do próprio Conselho Diretor no decorrer dos processos decisórios oferecendo-lhe referências concretas de decisão construídas em seu próprio cerne e por iguais.

Ademais, o sentimento de igualdade dos regulados em face das decisões regulatórias discricionárias da ANATEL poderia ensejar a sua melhor aceitação pelos regulados e fortalecimento da instituição Agência Reguladora.

Exposto, nestes termos, o primeiro parâmetro concreto e objetivo às decisões regulatórias discricionárias da ANATEL, importa apresentar o critério seguinte, a motivação.

V. 5. 2. A Motivação Positiva e Negativa de Todos os Atos do Processo Decisório.

O segundo parâmetro concreto e objetivo que propomos para o acompanhamento pelos interessados dos processos decisórios da ANATEL e para a eventual confrontação das decisões regulatórias discricionárias desses decorrentes é o teste 
da motivação positiva e negativa de todos os atos integrantes do processo decisório e especialmente de sua decisão discricionária final.

A Constituição Federal de 1988 não se refere expressamente à necessidade de motivação dos atos administrativos, à exceção da exigência de motivação das decisões administrativas dos Tribunais, nos termos do art. 93, $\mathrm{X}$ da $\mathrm{CF}^{515}$. Não obstante, há consenso na doutrina administrativa de que essa ausência não elide o dever de a Administração Pública motivar seus atos. ${ }^{516}$

A nosso ver, a falta de norma explícita que imponha a motivação dos atos administrativos, da mesma forma, não dispensa a obrigatoriedade de sua motivação. ${ }^{517}$ Ademais, também não fazemos distinções entre a necessidade de que a Administração Pública motive, indistintamente, os atos vinculados e os discricionários. ${ }^{518}$ Como vimos no Capítulo I da dissertação, entendemos que existem graduações de vinculação e discricionariedade dos atos administrativos; assim, parece-nos que a importância de se motivar os atos administrativos é diretamente proporcional a discricionariedade que lhes é atribuída. Logo, quanto mais discricionário o ato maior a importância da sua motivação pela autoridade pública. O que não significa que os atos administrativos que gozem de maior grau de vinculação (ou menor grau de discricionariedade) não devam ser motivados, ao contrário, esses também deverão ser motivados, contudo, a princípio, a relevância da

515 Odete MEDAUAR ressalva que nos trabalhos de elaboração da CF de 1988 tentou-se introduzir a motivação como princípio da Administração Pública, mas que ao final essa idéia não permaneceu no texto final. Direito Administrativo Moderno, p. 137.

516 Dois são os principais argumentos nesse sentido. Um, na linha sustentada por Diogo de Figueiredo MOREIRA NETO e Celso Antonio BANDEIRA DE MELLO, residente na interpretação extensiva do conteúdo do art. 93, X da CF, no sentido de que se o Poder Judiciário está obrigado a motivar as suas decisões administrativas, com mais razão estariam os Poderes Legislativo e Executivo ao proferirem suas respectivas decisões administrativas, pois somente assim seria garantido o efetivo controle realizado pelo Poder Judiciário. E, outro, na linha defendida por Carlos Ari SUNDFELD e ODETE MEDAUAR, para os quais o dever de a Administração Pública fundamentar seus próprios atos é base e decorrência do Estado de Direito. Mutações de Direito Público, p. 290-291. Discricionariedade e Controle Judicial, 103. Motivação do Ato Administrativo como Garantia dos Administrados, p. 120-121. Direito Administrativo Moderno, p. 137.

517 Nesse sentido, concordamos com Odete MEDAUAR para quem nas atuações administrativas processualizadas, a motivação é decorrência de garantia do contraditório dos administrados. Direito Administrativo Moderno, p. 167

518 Esse é também o entendimento de Maria Sylvia Zanella DI PIETRO, Direito Administrativo, p. 77. Entendimento diverso apresenta Carlos Ari SUNDFELD para quem a fundamentação expressa dos atos vinculados poderia ser dispensável quando estivesse contida, implícita e claramente, no conteúdo do ato, de prática obrigatória, baseado em fato sem qualquer complexidade. Motivação do Ato Administrativo como Garantia dos Administrados, p.121-123 e 125. Celso Antonio BANDEIRA DE MELLO compartilha do entendimento de Carlos Ari SUNDFELD. Discricionariedade e Controle Jurisdicional, p. 103 e ss. 
motivação nesses casos seria menor, haja vista que esses devem corresponder basicamente aos comandos legais.

Juarez FREITAS pondera com precisão que a era da motivação longe está de assegurada. Para o autor, com o qual concordamos, faz-se inadiável consolidá-la, pois a motivação é escudo do cidadão contra arbitrariedades e desvios invertebrados. Os vícios aparecem quando a justificação se eclipsa. Por isso, citando Lúcia Valle FIGUEIREDO afirma: “a motivação deve ser a pedra-de-toque para o controle da discricionariedade". 519

A discricionariedade administrativa precisa, como nunca, apresentar-se motivadamente vinculada ao sistema, já que, no plano concreto, bem observada, nenhuma escolha administrativa se mostra indiferente. ${ }^{520}$

Expostos, nessa medida, os seus fundamentos e abrangência é preciso, antes de apresentar a motivação como um parâmetro concreto de aferição do exercício da discricionariedade pelo regulador, tratar de seu conteúdo.

Motivar é exteriorizar as razões de decisão expressas no ato administrativo. É demonstrar expressa e explicitamente ${ }^{521}$ o processo cognitivo, avaliativo e decisório da autoridade pública. A motivação é, comumente, definida pela doutrina administrativista como a fundamentação ou enunciação dos fatos e do direito que dão supedâneo à decisão administrativa.

Antonio Carlos de Araújo CINTRA, acompanhando TARUFFO, afirma que a motivação apresenta-se como um discurso justificativo da decisão contida no ato motivado, por meio da qual, o agente público procura argumentar para convencer outrem sobre as razões do ato administrativo emanado, tanto sob o aspecto da legalidade como da oportunidade e conveniência. ${ }^{522}$

No mesmo sentido é o entendimento de Celso Antônio BANDEIRA DE MELLO para quem a motivação é a justificação do ato administrativo, por meio da qual autoridade pública deve além de indicar a base legal em que estriba sua decisão, indicar os

\footnotetext{
${ }^{519}$ Discricionariedade Administrativa e o Direito Fundamental à Boa Administração Pública, p. 50.

${ }^{520}$ Discricionariedade Administrativa e o Direito Fundamental à Boa Administração Pública, p. 15.

${ }^{521}$ Diogo de Figueiredo MOREIRA NETO, ao novo ver equivocadamente, afirma que a motivação pode ocorrer também implicitamente. Entendemos, ao contrário, que a motivação das decisões administrativas sempre deve ser explícita, clara e objetiva; e, nesse sentido, estamos ao lado de vertente majoritária da doutrina administrativista. Mutações de Direito Público, p. 290.

${ }^{522}$ Motivo e Motivação do Ato Administrativo, p. 106-107.
} 
fatos ou circunstâncias sobre os quais se apóia e, em havendo discrição, deve indicar a pertinência lógica entre os fatos e a medida adotada, de modo a que se possa compreender sua idoneidade para lograr a finalidade legal. ${ }^{523}$

Motivo e motivação não se confundem. E nessa medida não entraremos no tema da Teoria dos Motivos Determinantes. Basta-nos registrar, nesse sentido, que os motivos apresentados para a prática do ato administrativo vinculam a autoridade pública. ${ }^{524}$

Celso Antonio BANDEIRA DE MELLO assim justifica o teor que entende possuir a motivação:

"Faltando a enunciação da regra jurídica proposta como aplicanda, não se terá como saber se o ato é adequado, ou seja, se corresponde à competência utilizada; omitindo-se a enunciação dos fatos e situações à vista dos quais se está procedendo de dado modo, não se terá como controlar a própria existência material de um motivo para ele e, menos ainda, seu ajustamento à hipótese normativa: carecendo de fundamentação esclarecedora do porquê se agiu da maneira tal ou qual não haverá como reconhecer-se, nos casos de discrição se houve ou não razão prestante para justificar a medida e, pois, se ela era, deveras, confortada pelo sistema normativo." 525 (grifos no original)

Marçal JUSTEN FILHO, complementa, ainda, esses elementos, indicando que cabe à autoridade pública apontar os princípios jurídicos escolhidos para nortear sua decisão e os processos de valoração que entranharam a atividade decisória. ${ }^{526}$

Temos como certo, à esteira desses doutrinadores, que a motivação deve compreender, portanto, (i) o fundamento jurídico com base no qual a decisão foi tomada e a sua articulação; (ii) a indicação dos fatos e a sua avaliação, positiva ou negativa, ou seja, caso existam fatos que não sejam apreciados na decisão administrativa, a autoridade pública deve explicar porquê assim considerou; (iii) em havendo discrição, a autoridade

\footnotetext{
${ }^{523}$ Discricionariedade e Controle Jurisdicional, p. 99.

${ }^{524}$ A esse respeito, ver por todos, a importante e sólida obra de Antônio Carlos de Araújo Cintra. Motivo e Motivação do Ato Administrativo.

${ }^{525}$ Discricionariedade e Controle Jurisdicional, p. 99.

${ }^{526}$ Curso de Direito Administrativo, p. 263.
} 
pública deve expor as razões e os critérios de suas ponderações, exteriorizando a racionalidade de seu processo decisório. Ademais, acreditamos que a autoridade pública deve, ainda, (iv) apresentar a análise de todos os argumentos apresentados pelos interessados, mesmo que seja para afastá-los; e (v) expor a avaliação que se fez acerca dos dados e informações técnicas aportadas pelos interessados e pelos órgãos técnicos da Administração Pública, especialmente no caso das Agências Reguladoras, inclusive aqueles consolidados em pareceres, informes, notas técnicas etc. ${ }^{527}$

Note-se que reputamos de extrema importância a justificação positiva e negativa de apreciação de todos os argumentos e documentos aportados aos autos dos processos decisórios. Mais que um dever imposto pela Lei n. ${ }^{0} 9.784 / 1999^{528}$, é condição imprescindível para afugentar o arbítrio do agente estatal.

De fato, de nada adiantaria o dever de a autoridade pública motivar seus atos, se essa pudesse selecionar os fatos, os argumentos e os documentos a considerar no processo de justificação da decisão tomada. No Estado Democrático de Direito não se pode aceitar rejeições implícitas. A Administração Pública tem o dever de decidir sobre todos os elementos aportados ao processo decisório ${ }^{529}$, quando mais, nos processos decisórios discricionários atinentes à mediação ativa de interesses.

Marçal JUSTEN FILHO é taxativo ao constatar que a recusa da autoridade pública em responder as argüições formuladas pelos administrados é ato arbitrário. ${ }^{530}$

A esse respeito Odete MEDAUAR observa também que:

"A oportunidade de reagir ante a informação seria vã se
não existisse fórmula de verificar se a autoridade
administrativa efetivamente tomou ciência e sopesou as
manifestações dos sujeitos. A este fim responde a regra da
motivação dos atos administrativos. Pela motivação se

${ }^{527}$ Nesse sentido, entendemos que o $\$ 1^{\circ}$ do art. 50 da Lei de Processo Administrativo Federal não autoriza a mera colagem ou anexação desses documentos aos atos e decisões administrativas para a sua justificação. Parece-nos que tal dispositivo ao ditar que deve existir "declaração de concordância" com esses documentos exige que a autoridade pública demonstre a avaliação que fez acerca das informações e dados por esses aportados aos autos.

${ }_{528}$ Vide art. $2^{\circ}$, VII e art. 50 da Lei de Processo Administrativo Federal.

${ }^{529}$ Esse é também o entendimento de Marçal JUSTEN FILHO. Curso de Direito Administrativo, p. 263.

${ }^{530}$ Curso de Direito Administrativo, 263. 
percebe como e quando determinado fato, documento ou alegação influiu na decisão final..." 531 (grifos nossos)

É o que Lúcia Valle FIGUEIREDO resumiu em poucas palavras como lhe era peculiar:

$$
\begin{aligned}
& \text { "A motivação, embora possa ser sucinta, deve demonstrar - } \\
& \text { de maneira cabal - o iter percorrido pelo administrador } \\
& \text { para chegar à prática do ato." }{ }^{332}
\end{aligned}
$$

Floriano de Azevedo MARQUES NETO registra que para que o controle das decisões administrativas seja possível é preciso que haja uma motivação profunda e comprida e, bem assim, a fundamentação das razões pelas quais a autoridade pública adotou um determinado juízo discricionário e não outro, isto é, porque privilegiou um determinado interesse e não outro. ${ }^{533}$

Apreendido, pois, o conteúdo da motivação dos atos e decisões administrativas, é preciso consignar que a justificação apresentada pela autoridade pública deve ser absolutamente compreensível pelo público em geral. Deveras, a motivação inacessível seria inócua e imprestável para os seus fins.

Nesse sentido, Antonio Carlos de Araújo CINTRA anota que a motivação deve atender a três requisitos: suficiência, clareza e congruência ${ }^{534}$ Explica o autor que a motivação deve ser suficiente no sentido de sua precisão, repercutindo as peculiaridades do caso concreto e não se fixando em repetições genéricas e vagas das normas. Deve, ainda, ser clara e congruente a fim de possibilitar a efetiva comunicação com os seus destinatários, pois, do contrário se revelaria obscura e ininteligível e redundaria em incerteza e insegurança acerca da decisão administrativa. ${ }^{535}$

\footnotetext{
${ }^{531}$ Direito Administrativo Moderno, p. 167.

532 Curso de Direito Administrativo, p. 101.

${ }^{533}$ Discricionariedade Administrativa e Controle Judicial da Administração Pública, p. 461.

${ }^{534} \mathrm{O} \S 1^{\circ}$ do art. 50 da Lei de Processo Administrativo fala em explicitude, clareza e congruência.

${ }^{535}$ Motivo e Motivação do Ato Administrativo, p. 128-129.
} 
A importância do dever de a Administração Pública motivar os seus próprios atos e decisões ${ }^{536}$, por sua vez, é reconhecida amplamente pela doutrina administrativista, especialmente em sua instrumentalidade para o controle do agir administrativo.

Celso Antonio BANDEIRA DE MELLO precisamente questiona: "como contestar a validade de um ato se os seus motivos, se sua razão de ser permanecer ignorada, oculta? Como impugná-lo, como submetê-lo ao crivo jurisdicional, se forem, desde logo, desconhecidas as bases em que está assentado? „537

Com efeito, a motivação, ato a ato, nos processos decisórios é imprescindível para o acompanhamento e confrontação das decisões administrativas pelos interessados e órgãos de fiscalização ${ }^{538}$, especialmente as discricionárias. Em outras palavras, para que o controle das decisões administrativas possa ser realizado é indesviável que as razões e critérios de decisão da autoridade pública sejam conhecidos. ${ }^{539} \mathrm{E}$ a exposição do percurso realizado pelo agente estatal, passo a passo, até o ato final do processo decisório que permitirá a aferição da correção e da adequação da decisão do caso concreto.

Mas não é apenas essa a importância da motivação das decisões administrativas.

A motivação propicia, ainda, um reforço da transparência administrativa ${ }^{540}$ (outro parâmetro importantíssimo que veremos no item seguinte) e, por conseguinte, a motivação reduz o risco de arbitrariedades por parte das autoridades públicas ${ }^{541}$ e confere, assim, maior segurança jurídica aos interessados.

Mais que isso, a motivação força um maior cuidado e comprometimento da autoridade pública no exame das questões que lhe são apresentadas e na justificação da

\footnotetext{
536 Como anota Diogo de Figueiredo MOREIRA NETO “[p]or decisão, não se deve entender, porém qualquer ato administrativo ou judiciário que contenha uma ordem, senão aquele cujo comando aplique uma solução a litígios, controvérsias e dúvidas, conhecendo, acolhendo ou denegando pretensões, através das adequadas vias processuais, ainda que de ofício.” Mutações de Direito Público, p. 290.

${ }^{537}$ Discricionariedade e Controle Jurisdicional, p. 99.

${ }^{538}$ Sérgio GUERRA afirma que se trata da aplicação do princípio do hard look por meio do qual se permitirá o controle efetivo pelo Poder Judiciário, pois tal princípio visa obrigar a autoridade pública a valorizar devidamente os fatos e o direito constantes dos autos sob pena de invalidação da sua decisão pelos tribunais. Controle Judicial dos Atos Regulatórios, p. 265-266.

${ }^{539}$ É nesse sentido também o entendimento de Floriano de Azevedo MARQUES NETO. Discricionariedade Administrativa e Controle Judicial da Administração, p. 194-195.

${ }^{540}$ Também nesse sentido é o entendimento de Sérgio GUERRA. Controle Judicial dos Atos Regulatórios, p. 264. Cf. Odete MEDAUAR. Direito Administrativo Moderno, p. 167.

${ }^{541}$ Cf. Antonio Carlos de Araújo Cintra. Motivo e Motivação do Ato Administrativo, p. 113.
} 
legalidade e do eventual uso de conveniência e oportunidade das decisões administrativas discricionárias, na medida em que é sabedora da necessidade de justificá-las ao público. ${ }^{542}$

Por fim, a motivação ao longo dos processos decisórios, ato a ato, propicia uma decisão mais previsível e possibilita o diálogo continuo e a máxima participação das partes para compreender e auxiliar a formação final da decisão da autoridade pública.

Não se deve, entretanto, confundir o ato de motivar com o ato administrativo principal ou com o núcleo da decisão administrativa. Trata-se de atos diversos como bem apontam Antonio Carlos de Araújo e Cintra e Carlos Ari SUNDFELD. Esses autores sustentam que motivação é um ato distinto do ato administrativo a ser justificado. Para o segundo autor, ainda, a motivação é um requisito procedimental do ato administrativo com conteúdo e forma próprios; de modo que, a sua falta ou defeito propicia a invalidade do ato administrativo. $^{543}$

Por derradeiro, cumpre registrar uma última nota, no sentido de que a motivação dos atos e decisões administrativas deve ser prévia ou contemporânea a produção destes, isto é, a justificação dos atos e das decisões administrativas devem ser anteriores ou concomitantes a sua expedição. Carlos Ari SUNDFELD pondera que a motivação não pode ser posterior "porque todo administrado tem o direito a insurgir-se contra atos ilegais e, em conseqüência, direito a saber se o ato é ou não legal, para se decidir entre a aceitação e o recurso ao Judiciário. Só pode sabê-lo com precisão se estiverem reveladas as razões determinantes da prática do ato. É no mínimo ‘desleal ocultar motivos que pudessem ter convencido ou terem sido refutados oportunamente na via administrativa e exibi-los ou inventá-los (como sói ocorrer) ante a necessidade de justificar o ato frente à Justiça”. 544

Mais uma vez, a motivação não se prestaria ao atingimento de suas finalidades se se admitisse a sua postergação para depois da expedição dos atos e decisões administrativas. Entendemos, pois isso, que a anterioridade e a contemporaneidade da motivação é também um de seus requisitos.

\footnotetext{
${ }^{542}$ Cf. Antonio Carlos de Araújo Cintra. Motivo e Motivação do Ato Administrativo, p. 112-113. Sérgio Guerra afirma nesse sentido que: "Ademais, ao desvendar as razões que motivaram a decisão, permite-se à própria. entidade regulatória rever internamente os seus atos (...)”. Controle Judicial dos Atos Regulatórios, p. 264.

${ }_{543}$ Motivação do Ato Administrativo como Garantia dos Administrados, p.124-125.

${ }^{544}$ Motivação do Ato Administrativo como Garantia dos Administrados, p. 125.
} 
Com base em todo o exposto, propomos, pois, a motivação positiva e negativa de todo os atos dos processos decisórios e, bem assim, das decisões regulatórias discricionárias da ANATEL como parâmetro concreto e objetivo de aferição da correção dessas últimas.

Frise-se que, nos termos do art. 40 da LGT, a ANATEL tem o dever de justificar formalmente os motivos dos atos que produz. E não poderia ser diferente, haja vista que a Agência Reguladora é parte integrante da Administração Pública indireta.

Contudo, como vimos na PARTE II, Capítulo III da dissertação, tal como ocorre com diversos órgãos e entes estatais, a motivação dos atos e decisões administrativas discricionárias da ANATEL não é efetiva, isto é, não cumpre com as suas finalidades.

Constatamos no estudo de casos realizado que as decisões discricionárias da Agência Reguladora carecem de motivação suficiente, precisa, abrangente, coerente e extensiva. As ações e principalmente as opções discricionárias da ANATEL não são explicadas aos interessados e, bem assim, ao público em geral. As razões e os critérios de ponderação utilizados no processo decisório da Agência Reguladora não são apresentados e esclarecidos por seus conselheiros. Simplesmente se dita qual é a opção do regulador, na maioria das vezes, com pobreza de informações, sem que se explicitem quais foram os parâmetros de valoração empregados pelos conselheiros da ANATEL.

Propomos, nessa medida, que a ANATEL, sem parcimônia, motive positiva e negativamente seus atos e sua decisão final ao longo dos processos decisórios, especialmente os discricionários, apresentando, ao menos, os elementos que apontamos anteriormente e, que em razão de sua importância, tomamos a liberdade de repetir: (i) o fundamento jurídico com base no qual a decisão foi tomada e a sua articulação, isto é, não basta o seu apontamento, mas a enunciação de sua aplicação ou afastamento do caso concreto; (ii) a indicação dos fatos e a sua avaliação, positiva ou negativa, ou seja, caso existam fatos que não sejam apreciados na decisão administrativa, o regulador deve explicar porquê assim considerou, não basta apenas "copiar e colar" os fatos apresentados pelas partes; (iii) em havendo discrição, o regulador deve expor as razões e os critérios de suas ponderações, exteriorizando a racionalidade de seu processo decisório, não basta meramente avocar a sua competência; (iv) apresentar a análise de todos os 
argumentos apresentados pelos interessados, mesmo que seja para afastá-los, não basta somente avaliar os argumentos que sustentam a tese decisória; e (v) expor a avaliação que se fez acerca dos dados e informações técnicas aportadas pelos interessados e pelos órgãos técnicos da ANATEL, inclusive aqueles consolidados em pareceres, informes, notas técnicas etc., não basta, novamente, "copiar e colar" trechos desses documentos nas decisões para justificar a decisão proferida.

Não temos dúvidas de que a justificação explícita, ampla, precisa, clara, congruente, anterior ou contemporânea de todas as ações e opções do regulador ao longo dos processos decisórios de mediação ativa de interesses da ANATEL e, especialmente das decisões discricionárias finais destes, como proposto, possibilitaria o seu acompanhamento pelos interessados, o controle da atividade do regulador por esses e pelos órgãos de fiscalização competentes e, por que não, propiciando, a priori, um agir de seu Conselho Diretor mais coeso, coerente e adequado.

Ademais, afastaria o risco de arbitrariedades e propiciaria a construção de um ambiente de segurança jurídica no setor de telecomunicações.

Diga-se, por derradeiro, que a motivação dos atos e decisões regulatórias discricionárias, por óbvio, deve ser pública, assim como todo o processo decisório da ANATEL deve ser transparente. Evidentemente de nada adiantaria o dever de motivação dos atos e decisões da Agência Reguladora se esses permanecessem em segredo. É o que veremos no item seguinte: o parâmetro da transparência.

\section{5. 3. A Transparência do Processo Decisório.}

$\mathrm{O}$ terceiro parâmetro concreto e objetivo que propomos para o acompanhamento pelos interessados dos processos decisórios da ANATEL e para a eventual confrontação das decisões regulatórias discricionárias desses decorrentes é o teste da transparência.

O tema da transparência da Administração Pública, embora de suma importância para a concretização dos ideais do Estado Democrático de Direito, não recebe muita e aprofundada atenção da doutrina administrativista pátria, ao contrário, de modo geral é tratado de maneira bastante breve e superficial. 
Talvez a razão esteja na obviedade de que o Estado, se Democrático e, se de Direito, deve ser transparente ou, como alguns preferem, visível.

A visibilidade das ações estatais normalmente tem sua origem representada com a célebre obra de Norberto BOBBIO, "O Futuro da Democracia”, em que o jusfilosofo discorre sobre a relação entre democracia e poder, frisando suas concepções em duas sentenças que reverberam sempre que se estuda o tema da transparência da Administração Pública no âmbito dos Estados Democráticos: “a democracia (...) é o governo do poder visível” e "pode-se definir o governo da democracia como o governo do poder público em público". 545

Insurge, pois, do próprio princípio democrático dos Estados Contemporâneos, que a sua transparência (ou visibilidade) é a regra e o segredo é a exceção. ${ }^{546}$

Carlos Ari SUNDFELD de maneira bastante clara, como lhe é próprio, relembra de maneira ilustrada que a razão de ser do Estado Democrático de Direito está na coletividade e não em si mesmo:

"A razão de ser do Estado é toda externa. Tudo que nele se passa, tudo que faz, tudo que possui, tem uma direção exterior. A finalidade de sua ação não reside jamais em algum benefício íntimo (...)está sempre voltado para a coletividade (não para a pessoa estatal (...). Em uma figura: falta ao Estado vida interior, faltam-lhe interesses pessoais intimos." 547

Conclui, assim, o autor, que considerando, pois, que o Estado jamais maneja interesses, poderes ou direitos íntimos, tem o dever de absoluta transparência. Para Carlos Ari SUNDFELD "[é] óbvio, então, que o povo, titular do poder, tem o direito de conhecer tudo o que concerne ao Estado, de controlar passo a passo o exercício do poder. À margem disso, qualquer pessoa atingida pelo Poder Público - isto é, que de qualquer modo seja destinatária, prejudicada ou atendida por ato estatal - tem o direito individual de conhecer esse ato, suas razões, sua base fática e jurídica. Em conseqüência, seja em

\footnotetext{
${ }^{545}$ O Futuro da Democracia: Uma Defesa das Regras do Jogo, p. 83-84.

${ }^{546}$ Cf. Maria Sylvia Zanella DI PIETRO. Alcance do Princípio da Publicidade das Funções Públicas: Transparência e Sigilo, p. 202.

${ }^{547}$ Fundamentos de Direito Público, p. 177.
} 
nome da limpidez da atividade estatal, seja para garantia de direitos individuais, o estado tem o dever da publicidade." 548

Marçal JUSTEN FILHO compartilha do entendimento de Carlos Ari SUNDFELD:

"O exercício do poder deve ser acessível ao conhecimento de toda a comunidade e, especialmente, daqueles que serão afetados pelo ato decisório." 549

Celso Antonio BANDEIRA DE MELLO manifesta-se no mesmo sentido:

"Não pode haver em um Estado Democrático de Direito, no qual o poder reside no povo (art.1 $1^{\circ}$, parágrafo único, da Constituição), ocultamento aos administrados dos assuntos que a todos interessam, e muito menos em ração aos sujeitos individualmente afetados por alguma medida." 550

Com esses doutrinadores podemos inferir que a Administração Pública tem o dever de ser transparente porquanto curadora exclusiva dos interesses dos administrados e, unicamente, por essa razão suas ações se justificam. E, bem assim, que existem duas esferas de transparência da Administração Pública, uma coletiva, referente às ações estatais de maneira geral e outra individual, decorrente do direito de cada qual conhecer os atos administrativos, em detalhes, que de alguma forma lhe digam pessoal respeito.

Diogo de Figueiredo MOREIRA NETO sustenta, ainda, que a publicidade é o princípio instrumental mais importante do Direito Público e do Direito Administrativo e condição indispensável para a sindicabilidade da legalidade, da legitimidade e da moralidade das ações da Administração Pública. Afirma o jurista que a publicidade, no Direito Público, é um direito fundamental do administrado e que sem essa, seria impossível controlar a ação estatal e não passaria de uma falácia a sustentação dos direitos fundamentais e do próprio Estado de Direito. ${ }^{551}$

\footnotetext{
${ }^{548}$ Fundamentos de Direito Público, p. 177.

${ }^{549}$ Curso de Direito Administrativo, p. 248.

${ }^{550}$ Esse também é o argumento apresentado por Celso Antonio BANDEIRA DE MELLO. Curso de Direito Administrativo, p. 114.

${ }^{551}$ Mutações de Direito Público, p. 278.
} 
Na mesma ordem de convicções, Juarez FREITAS assevera que a publicidade ou transparência máxima nas relações com a Administração Pública é um dos pilares do seu controle sistemático que "estimula a fluência das informações indispensáveis à eficácia do direito fundamental à boa administração pública, uma vez que a opacidade é a antítese de tal direito, que demanda alta dose de translucidez para se desenvolver $e$ frutificar." 552

De fato, parece-nos ser a transparência da Administração Pública um instrumento e parâmetro de alta importância para o controle dos atos e decisões administrativas. É quase natural que atuemos de maneira mais contida, cuidadosa e justificável em uma casa de vidro ${ }^{553}$ onde todos e cada um podem acompanhar suas atividades, escolhas e resoluções. A visibilidade da Administração Pública está, assim, a nosso ver, diretamente imbricada com um agir administrativo mais responsável e probo, antes mesmo de ser ferramenta essencial para o seu acompanhamento e confrontação.

É preciso conhecer o comportamento, as ações, as opções, os atos e processos decisórios da Administração Pública para que se possa acompanhá-los e controlá-los. A administração às escuras, em segredo, favorece o arbítrio e revela-se insindicavél, pois, ignorada.

Em síntese, a escuridão e a opacidade propiciam o arbítrio. A transparência o repele.

Fixadas essas idéias iniciais de que o dever de transparência é intrínseco ao Estado Democrático de Direito, é direito fundamental do administrado e, nesse sentido, todos e cada um detêm o direito de conhecer o agir administrativo, representando, per se, importante instrumento e parâmetro de controle dos atos e decisões administrativas, é preciso esclarecer o porquê do próprio termo que utilizamos (transparência e não publicidade ou visibilidade) e o seu alcance, de modo a tornar o parâmetro ora proposto inequívoco.

A doutrina administrativista não é uníssona na utilização dos termos e do conteúdo intrínseco à transparência, publicidade e visibilidade. Muitas vezes esses termos

\footnotetext{
${ }^{552}$ O Controle dos Atos Administrativos, p. 94.

553 A expressão é do português Luís Filipe Colaço Antunes em seu ensaio Mito e realidade da Transparência Administrativa, p. 7.
} 
são utilizados como sinônimos e têm o mesmo alcance outras, ainda, são aplicados com amplitudes diferentes.

Entendemos que o termo transparência é mais genérico e engloba o que normalmente se trata como publicidade na doutrina administrativista. Porém não nos parece que em seu cerne estejam abrangidos outros institutos como a motivação, a participação ou o devido processo legal, tal como entende Maria Sylvia Zanella DI PIETRO. ${ }^{554}$ Isso não quer dizer que negamos a relação entre todos esses institutos - como afirmamos no item anterior, é evidente que de nada adiantaria o dever de motivação das decisões administrativas se essa fosse mantida em segredo - mas, tão-somente, que entendemos a transparência como um instituto autônomo.

Compreendemos, pois, como transparência o dever de a Administração Pública dar a conhecer todas as suas atividades e opções, a qualquer tempo, e atos e processos, em formação, em andamento, concluídos e arquivados e não meramente o dever de divulgação oficial de seus próprios atos comumente associado à publicidade em sentido estrito. Conferimos, assim, à transparência o sentido amplo de publicidade que lhe é atribuído por Carlos Ari SUNDFELD:

"Não obstante, estamos a falar em publicidade em sentido mais largo. Evidente que o Estado deve divulgar seus atos, como condição de existência e validade deles, mas não se resumem nisso seus deveres para com a publicidade. Em paralelo, tem o dever de agir de modo diáfano, de se franquear ao conhecimento público, de se desnudar, mesmo quando não esteja em pauta a notificação de seus atos." 555 (grifos nossos)

É exatamente por sua amplitude alargada que optamos por propor a transparência como parâmetro de atuação da ANATEL, especialmente no que tange aos processos decisórios que envolvem alguma discricionariedade da Agência Reguladora.

\footnotetext{
${ }_{554}^{55}$ Alcance do Princípio da Publicidade das Funções Públicas: Transparência e Sigilo, p. 202 e ss. ${ }^{555}$ Fundamentos de Direito Público, p. 178.
} 
O termo publicidade, por sua vez, é comumente utilizado em seu sentido estrito, de divulgação oficial dos atos administrativos para conhecimento público e início de seus efeitos externos. ${ }^{556}$

E, por fim, o termo visibilidade é utilizado como sinônimo de transparência ou publicidade em sentido amplo.

Esclarecido, assim, o que entendemos por transparência cumpre passar, de maneira bastante breve, aos seus fundamentos constitucionais e legais, antes de tratarmos especificamente o atual contexto da Agência Reguladora.

O fundamento constitucional do dever de transparência decorre da combinação do preceito basilar do caput do art. 37 da Constituição Federal, em que se consagra a publicidade como um dos princípios diretores da Administração Pública, com outros dispositivos constitucionais, especialmente, dentre tantos outros, aqueles do art. $5^{\circ}$, atinentes às garantias e direitos fundamentais, constantes dos incisos XXXIII, XXXIV (direito à informações e à certidões), LXXIII (habeas data que instrumentaliza o direito à obtenção de informações de caráter pessoal), LX e art. 93, IX (publicidade no âmbito processual). ${ }^{557}$

Em âmbito legal, na seara da Lei n. ${ }^{\circ}$ 9.784/1999, embora a transparência não esteja elencada dentre os princípios diretores da Administração Pública em seu art. $2^{\circ}$, está espraiada em toda a norma. Cite-se, exemplificativamente, o art. $2^{\circ}, \mathrm{V}$ (publicidade em sentido estrito), art. $3^{\circ}$, II e art. 46 (direito dos administrados a ter ciência, vista e cópia dos autos e documentos e conhecer as decisões).

A transparência tem relação direta com o sigilo e, assim é também no âmbito constitucional, normativo e regulatório, em que muitos são os enunciados que resguardam, excepcionalmente, situações em que dados, informações e documentos podem ser protegidos em caso de segurança da sociedade e do Estado (art. $5^{\circ}$, XXXIII, in fine) e, na esfera individual preservação da intimidade, vida privada, honra e imagem das pessoas

\footnotetext{
${ }^{556}$ Cf. Hely Lopes MEIRELLES. Direito Administrativo Brasileiro, p. 87-88.

${ }^{557}$ Carlos Ari SUNDFELD afirma que o princípio da publicidade ampla, como denomina, não carecia de expressão normativa, para incidir, uma vez que decorreria do próprio sistema constitucional adotado. Mas que em razão de sua importância, mereceu sucessivas referências na Constituição Federal. Fundamentos de Direito Público, p. 178 e ss.
} 
(art. $5^{\circ}, \mathrm{X}$ da $\mathrm{CF}$ ) repercutindo em diversas leis, tal como no art. 46 da Lei n. ${ }^{\circ}$ $9.784 / 1999 .{ }^{558}$

A Lei n. ${ }^{\circ}$ 9.472/1997 (LGT) e a regulamentação do setor de telecomunicações, por sua vez, reforçam o caráter público e transparente das ações da ANATEL em diversos dispositivos e pontuam as situações de sigilo. Iremos apresentá-los tal como predicado nas normas e, mais adiante, os comentaremos com vistas à realidade vivenciada junto à Agência Reguladora, em mais de uma década, a fim de contextualizar o cenário da transparência na ANATEL in concreto.

Esclarecemos que nesse tratamento específico do tema nos valeremos do termo publicidade para ser fiel à linguagem disposta na LGT e na regulamentação setorial, mas, lembramos que, nesse sentido, se referem apenas a alguns aspectos integrantes do universo mais amplo da transparência.

De maneira geral, o art. 19 da LGT, que enuncia as competências da Agência Reguladora, elenca como seu dever, dentre outras diretrizes, a atuação da ANATEL com publicidade (caput).

Em seguida vem uma série de dispositivos importantes para a instrumentalização do dever de publicidade da Agência Reguladora. O art. 21 da LGT ao tratar das sessões do Conselho Diretor, estabelece que as suas atas fiquem arquivadas na Biblioteca, disponíveis para conhecimento geral $\left(\S 1^{\circ}\right)$ e que as sessões deliberativas são públicas, sendo permitida a sua gravação e assegurado aos interessados o direito de obter transcrições dessas $\left(\S 2^{\circ}\right) .{ }^{559}$

A Lei n. ${ }^{\circ}$ 9.472/1997 veja-se possui um título próprio à atividade e controle da ANATEL, o Título IV. ${ }^{560}$

O primeiro dispositivo desde título reafirma o dever de a Agência Reguladora agir de acordo com o princípio da publicidade, dentre outros (art. 38 da LGT).

O dispositivo seguinte, o art. 39 da LGT, determinada que todos os documentos e autos permaneçam abertos à consulta do público em geral, sem

\footnotetext{
${ }^{558}$ Sobre o tema ver o detalhado artigo de Maria Sylvia Zanella DI PIETRO, Alcance do Princípio da Publicidade das Funções Públicas: Transparência e Sigilo, p. 201 e ss.

${ }_{559}$ Dispositivo que é repetido nos arts. 32 e 33 do Decreto n. ${ }^{\circ}$ 2.338/1997, Regulamento da ANATEL.

${ }^{560} \mathrm{O}$ Regulamento da ANATEL repete as disposições desse título em seu capítulo V.
} 
formalidades, na Biblioteca, salvo aqueles que possam violar a segurança nacional, segredo protegido e a intimidade de alguém. A ANATEL vê, ainda, garantir tratamento confidencial às informações técnicas, operacionais, econômico-financeiras e contábeis que solicitar às empresas prestadoras de serviços de telecomunicações (parágrafo único).

O art. 42 da LGT afirma à submissão à consulta pública das minutas de atos normativos - firmando, assim, um importante mecanismo de participação dos interessados na atuação da ANATEL - e, bem assim, que as críticas e sugestões devem ser examinadas pelo regulador e permanecer à disposição do público também na Biblioteca da Agência Reguladora.

A publicidade é, ainda, enfatizada na contratação de obras e serviços, nos processos licitatórios e fixação de tarifas (art. 55, VIII, art.92 e 109 da LGT).

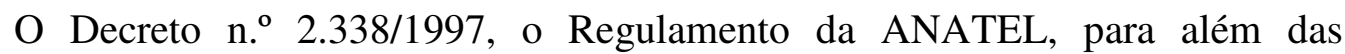
repetições de dispositivos da LGT, aprofunda alguns temas relativos ao Conselho Diretor da Agência Reguladora; dentre esses, merece destaque o tratamento conferido à transparência e probidade da atuação de seus conselheiros (art. 29, §2 $^{\circ}$ do Decreto) quando da abordagem das questões de suspeição e impedimento (art. 29 do Decreto).

A Resolução n. ${ }^{\circ}$ 270/2001 da ANATEL, que fixa o seu Regimento Interno (RI), aprofunda, também, alguns mecanismos de transparência da Agência Reguladora.

A publicidade das sessões deliberativas é reafirmada $\left(9^{\circ}\right.$ do $\left.\mathrm{RI}\right)$. $\mathrm{O}$ art. $8^{\circ}, \S 3^{\circ}$ menciona a possibilidade de se dar a oportunidade de debate oral aos interessados nas decisões da Agência Reguladora. Estabelece-se que as pautas devem ser previamente publicadas na Biblioteca da Agência Reguladora (art. $9^{\circ}$, $\S 2^{\circ}$ do RI) e que as atas devem ser preparadas em até cinco dias $\left(\operatorname{art} .15, \S 1^{\circ}\right.$ ), na qual devem constar a transcrição dos votos de cada conselheiro, com a sua fundamentação (análise), nos termos do art. 15, VII do RI.

Detalha-se, também, o procedimento das reuniões e circuitos deliberativos (art. 16 a 22 e art. 23 a 26 , respectivamente).

Não se assegura a publicidade das reuniões deliberativas da ANATEL, talvez porque essas estejam limitadas a tratar dos assuntos interno da Agência Reguladora (art. 16 RI), ao que os órgãos de fiscalização competentes possuem mecanismos específicos para a 
obtenção de informações. Não obstante, são aplicáveis às reuniões deliberativas as mesmas regras para a publicação de pauta, ata, análises e votos das sessões deliberativas (art. 16, $\S 1^{\circ}$ e 22 do RI). ${ }^{561}$

Já os circuitos deliberativos são procedimentos decisórios abreviados e, nessa medida, não comportam publicidade aos interessados ou ao público em geral para mais do que o acesso para conhecimento do seu objeto, prazo e estado na Biblioteca da ANATEL (art. 25 do RI), antes da publicação da decisão.

As disposições regulatórias a respeito dos procedimentos administrativos de alguma maneira reafirmam o estabelecido na Lei de Processo Administrativo Federal. Assegura-se, no entanto, durante a instrução dos processos administrativos, a vista dos autos às partes, mediante solicitação informal, sempre que não prejudicar o seu curso, a qual é obrigatória no período para manifestações das partes e interposição de recursos (art. 40, caput e $\S 1^{\circ}$ do RI). Prevê-se, também, a concessão de vistas dos autos, fornecimento de certidões e cópias de dados e documentos dos autos a terceiros interessado, ressalvados os casos de sigilo em virtude de lei ou de prévia declaração motivada nas hipóteses legais (art. $40, \S 2^{\circ}$ do RI).

Exceção feita ao Procedimento para Apuração de Descumprimento de Obrigações (PADO) que de acordo com o art. 79 do RI são sigilosos até o seu encerramento.

São fixadas, ainda, as regras da audiência pública (art. 42 a 44 do RI) e da consulta pública (art. 45 do RI), ressalte-se a respeito dessa última que os comentários e sugestões apresentados à ANATEL, devem ser analisados e as razões para a adoção ou não das sugestões dos participantes do processo devem ser apresentadas pela Agência Reguladora e arquivadas na Biblioteca á disposição do público interessado (art. $45, \S 2^{\circ}$ do $\mathrm{RI})$.

Essas são as previsões legais e regulatórias que direta ou indiretamente estão vinculadas ao tema da transparência da ANATEL.

A realidade, entretanto, demonstra que muitas das disposições que vimos acima não são observadas pela Agência Reguladora na sua prática diária.

\footnotetext{
${ }^{561}$ Recentemente, alterações regulatórias atinentes ao tema surgiram. Referidas alterações são comentadas em detalhes mais a frente neste mesmo item.
} 
Nossa atuação diária junto à ANATEL evidenciou, ao longo dos anos, algumas situações de absoluta falta de transparência da Agência Reguladora, não amparadas na legislação e na regulamentação setorial, que merecem ser descritas como exemplos que justificam a adoção do parâmetro da transparência como um dos critérios objetivos imprescindíveis ao acompanhamento in concreto dos atos e decisões regulatórias discricionárias da ANATEL e a sua confrontação em juízo.

Quatro relatos ilustram bem algumas das falhas na transparência da ANATEL o que, sem dúvida, podem contribuir para a eventual prática de arbitrariedades nos processos decisórios da Agência Reguladora.

Um primeiro relato necessário diz com a ausência de transparência das sessões deliberativas do Conselho Diretor em que assuntos que interessam aos agentes de mercado, fornecedores e usuários de serviços de telecomunicações são tratados. Como se sabe, até muito recentemente (como veremos adiante), essas sessões ocorriam a portas fechadas, de maneira secreta, sem a possibilidade de se ter acesso, ainda que de maneira externa por meio de transmissões audiovisuais, dos debates e votação dos conselheiros da ANATEL. Da mesma forma, não era e não será, ainda, permitida a intervenção oral dos interessados nas decisões do Conselho Diretor. Esse fato, aliado à ausência de publicação ou publicação a destempo das Atas das reuniões deliberativas da ANATEL e das Análises e Votos dos conselheiros da Agência Reguladora obsta que os interessados conheçam os argumentos e as razões de decidir da Agência Reguladora e, bem assim, que o público em geral conheça os posicionamentos da ANATEL. Frise-se, em razão da gravidade do relato, que em grande parte das vezes, - especialmente em casos paradigmáticos do setor e, que nessa medida, poderiam constituir precedentes da Agência Reguladora no sentido que afirmamos em V. 5. 1 -, após as reuniões do Conselho Diretor as Atas, Análises e Votos dos conselheiros $^{562}$ não são publicadas na Biblioteca da ANATEL, isto é, não se encontram disponíveis no site da Agência Reguladora, tampouco, são acessíveis por meio de contato telefônico ou eletrônico com a Biblioteca ou com os gabinetes dos conselheiros.

Um segundo relato pertine com a não disponibilização na Biblioteca da ANATEL de todos os documentos e da integralidade dos autos, muito menos, sem formalidades como requer a LGT. Uma simples busca no site da ANATEL evidencia que

562 Justa e apreciada exceção deve ser registrada à conselheira Emília Maria Silva Ribeira que desde que assumiu suas funções atua com absoluta e irrepreensível transparência publicando rotineiramente e em tempo suas Análises e Votos. 
existem incontáveis buracos no acervo de documentação e processos disponíveis eletronicamente. Mais que isso, é que o sistema eletrônico de solicitação e obtenção de cópias de documentos e, vista e cópia de autos, é ineficaz, quase inexistente. Raras são as solicitações de cópias de documentos (Análises, Votos, Pareces e Informes especialmente) atendidas. As negativas da ANATEL são sempre desarrazoadas e, no mais das vezes, se refere a afirmação de que aqueles que não são parte diretamente interessada, não poderiam ter acesso à documentação ou aos autos, o que sabemos ser absolutamente equivocado. ${ }^{563}$

Um terceiro relato refere-se a ausência de apresentação de estudos e documentos que embasem as propostas das Consultas Públicas realizadas pela Agência Reguladora e, bem assim, a não apresentação da análise da ANATEL acerca dos comentários apresentados pelos interessados às consultas públicas realizadas. Por vezes, os regulados são surpreendidos com a publicação de nova regulamentação sem que a Agência Reguladora manifeste-se acerca de suas contribuições (acatadas e rejeitadas).

Um último relato a ser feito concerne a ausência de publicidade dos PADOs durante o seu andamento, o que efetivamente coloca os regulados em posição de absoluta fragilidade e exposição ao arbítrio da ANATEL. Também com relação aos processos é importante registrar a dificuldade - quando não absoluto óbice - dos interessados em conhecer o posicionamento das áreas técnicas da Agência Reguladora acerca das situações que lhes são apresentadas, isto é, de se ter acesso aos Informes produzidos ao longo dos processos decisórios da ANATEL.

O primeiro passo para mudar esse cenário foi dado pela conselheira Emília Maria Silva Ribeiro, em 13/01/2010, com a instauração do processo n. ${ }^{\text {o }}$ $53500.000831 / 2010$ destinado à revisão do Regimento Interno da ANATEL. ${ }^{564}$

\footnotetext{
${ }^{563}$ Veja-se nosso próprio exemplo na árdua tarefa de pesquisar casos concretos da ANATEL. Identificar o universo de precedentes existente revelou-se um trabalho ingrato e de difícil precisão. Além disso, identificados os casos para estudo, acessar os seus documentos rendeu-nos mais uma série de angústias, haja vista a não disponibilização pela ANATEL (nem mesmo com expressos, gentilíssimos, insistentes e justificados pedidos) de parcela da documentação que reputamos relevante para conhecer as razões e critérios de decisão da Agência Reguladora. Exceção feita ao caso Brt-Oi em que a pressão da opinião pública foi tamanha que a ANATEL voluntariamente acabou por publicar todo o processo, de capa a capa, em seu site. A referência cruzada e, por vezes, a investigação indireta, por meio de documentação do Conselho Administrativo Econômico (CADE) mostraram-se assim ferramentas importantes para nosso estudo de casos. Ora conhecer os fundamentos de decisão da ANATEL deveria ser mais fácil não?
}

564 Antes mesmo, em 2008, por meio da Análise n. ${ }^{\circ}$ 40/2008, de 07/11/2008, por ocasião da discussão da revisão do Regulamento de Fiscalização e do Regulamento de Sanções Administrativas, a conselheira já 
Em 19/03/2010, a conselheira apresentou ao Conselho Diretor um projeto para dar mais transparência às decisões do Conselho Diretor da ANATEL e, segundo, veiculouse na imprensa essa medida criou um clima de guerra civil na Agência Reguladora, vez que a maioria dos conselheiros e superintendentes seria contrária à proposta e criaria barreiras para derrubá-la. ${ }^{565}$

Nesse projeto, apresentado por meio do Informe n. ${ }^{\circ}$ 001/2010-GCER, também de 19/03/2010, a conselheira reconheceu a insuficiência da transparência da ANATEL e a necessidade de que a Agência Reguladora seja efetivamente transparente. A conselheira afirmou nesse sentido que:

"O atual Regimento Interno é especialmente deficitário no que tange à transparência e à publicidade da atuação regulatória. Decisões de grande interesse para o setor e a sociedade ainda são tomadas em reuniões em que não se permite o acesso do público interessado. Paralelamente, a divulgação de documentos oficiais deve ultrapassar o estritamente necessário ao cumprimento de determinações legais. Uma agência reguladora verdadeiramente transparente deve dar conhecimento à sociedade de todos os fundamentos considerados em suas decisões, inclusive dos argumentos não acolhidos. Dessa forma, a divulgação das deliberações da Agência deve se fazer acompanhar da abertura dos estudos, informes, pareceres e votos, vencedores e vencidos, que fizeram parte do processo decisório." (p. 3-4) (grifos nossos)

Parece-nos absolutamente acertado o diagnóstico da conselheira, tal como suas conclusões.

Conforme ilustram apresentações da própria conselheira ${ }^{566}$, o objetivo de sua proposta é democratizar a ANATEL por meio da transparência e "superar a mera

tratara do tema da transparência; contudo, esse fora retirado de pauta pelo Conselho Diretor para a formação de um grupo técnico que nunca foi criado; razão pela qual, em 02/02/2010, a conselheira retomou os trabalhos destinados a conferir a ANATEL maior transparência.

${ }^{565}$ Jornal Folha de São Paulo, edição de sábado, dia 03 de abril de 2010.

${ }^{566}$ Tivemos acesso a três delas por gentileza de seu próprio gabinete: "Revisão do Regimento Interno da ANATEL: uma proposta para a democratização da regulação de telecomunicações", de 14/09/2010; e 
publicidade oficial de atos e tornar a atuação da Agência Reguladora verdadeiramente transparente e acessivel aos agentes e interessados".

Para tanto o foco do projeto está principalmente em três frentes: (i) transparência das deliberações, (ii) abertura de procedimentos, e (iii) informações sigilosas. Propõe a conselheira com relação ao foco (i) que (a) sejam abertas e transmitidas pela internet as sessões e reuniões do Conselho Diretor; (b) sejam divulgadas pela internet a íntegra das análises, dos votos e das gravações das deliberações do Conselho Diretor, (c) seja reduzido o papel dos circuitos deliberativos e que seu inteiro teor seja divulgado na internet; com relação ao foco (ii) que (a) sejam divulgados todos os documentos e estudos que fundamentam as Consultas Públicas da ANATEL, sejam apresentadas as razões do acolhimento ou rejeição das contribuições apresentadas a essas; (b) sejam transmitidas as audiências públicas pela internet; (c) os PADOS deixem de ser sigilosos durante o seu andamento; e com relação ao foco (iii) que (a) a publicidade seja a regra geral da Agência Reguladora; (b) somente aja sigilo nas hipóteses legais e constitucionais; (c) se aplique para as hipóteses de sigilo o Decreto n. ${ }^{\circ}$ 4.553/2002.

Discute-se, ainda, paralelamente, proposta para a elaboração de um regulamento de sigilo documental e processual da ANATEL, diante da necessidade de a Agência Reguladora estabelecer a classificação, reclassificação e desclassificação de documentos e processos quanto ao seu grau de sigilo. ${ }^{567}$

Recentemente, todavia, no final de outubro e início de novembro de 2011, o cenário descrito acima sofreu algumas alterações, ainda, que ao que pudermos constatar, até o encerramento deste estudo, maiormente no papel.

É que, em 28 de outubro, a ANATEL publicou a Portaria n. ${ }^{\circ}$ 941, dispondo sobre o acesso pelo público em geral aos documentos e informações acostados aos procedimentos de apuração de descumprimento de obrigações (PADOs), em atenção à sentença proferida nos autos da Ação Civil Pública n. ${ }^{\circ}$ 5007684-30.2010.404.7100/RS, que

"Anatel e Consumidor: por uma relação mais transparente", de 25/05/2011 e "Proposta de Alteração do Regimento Interno da ANATEL”, DE 16/04/2010.

${ }^{567}$ Este regulamento estaria em consonância com a Lei n. ${ }^{\circ} 8.159 / 1991$ e com o Decreto n. ${ }^{\circ} 4.553 / 2002$. O tema é tratado no processo n. $.^{\circ} 53500.029036 / 2006$, no qual consta a realização da Consulta Interna n. ${ }^{\circ}$ 487/2010, de 21 de junho a 23 de julho de 2010. Em 01/12/2011, por meio de deliberação do Conselho Diretor da ANATEL, em sua regular reunião semanal, determinou-se a devolução da proposta à Superintendência de Administração Geral da ANATEL para sua reavaliação e adequação aos termos da Lei $\mathrm{n}^{\mathrm{o}} 12.527$, de 18 de novembro de 2011, que revogou os dispositivos legais em que essa se baseava anteriormente. 
determinou que todos os PADOs, em trâmite na Agência Reguladora, fossem tornados públicos.

Em sequência, em 11 de novembro, a ANATEL publicou a Portaria n. ${ }^{\circ}$ 982, que estabeleceu os procedimentos para a transmissão audiovisual da distribuição por sorteio dos assuntos levados à decisão do Conselho Diretor e de suas reuniões deliberativas. ${ }^{568}$ De acordo com o Presidente da ANATEL, João Batista de Rezende, essa medida pretendia dar continuidade à "materialização de mecanismos que possibilitam maior transparência aos atos processuais da Agência". 569

Alguns comentários acerca das referidas portarias da ANATEL merecem ser apresentados.

O primeiro comentário, é certo, envolve algum julgamento pessoal acerca da iniciativa da ANATEL.

Há dois modos de receber a publicação dessas portarias. Um entusiasta e outro realista. Os entusiastas veriam com grande contentamento e deferência as medidas da Agência Reguladora para tornar-se mais transparente ao público em geral. Os realistas reconheceriam na primeira portaria um mero e restrito cumprimento compulsório de decisão judicial e na segunda uma tentativa, bastante limitada, de se colocar em prática medidas de transparência já previstas na LGT, no Regulamento e no Regimento Interno da ANATEL, há mais de dez anos.

Particularmente, temos uma visão bastante realista a respeito das iniciativas para a transparência da ANATEL, embora as tenhamos recebido de bom grado e reconheçamos que tal esforço deve ser elogiado. Explicamos.

De acordo com a Portaria n. ${ }^{\circ}$ 941/2011, os autos dos PADOs em trâmite na ANATEL serão públicos, em qualquer fase processual, ressalvados os casos de sigilo necessários em face do interesse social, preservação da intimidade dos envolvidos e

\footnotetext{
${ }^{568}$ Aqui é preciso esclarecer que o que a norma pretendeu foi tornar pública as sessões deliberativas do Conselho Diretor da ANATEL em que se deliberam assuntos de interesse dos regulados e não as reuniões deliberativas em que se tratam as questões administrativas da Agência Reguladora. Tal impropriedade no uso do termo reunião deve-se ao fato de que se acostumou a tratar a ambas, sessões e reuniões, genericamente como Reuniões do Conselho Diretor, em que matérias relativas as esferas do regulado e da ANATEL são decididas em uma mesma oportunidade.

${ }^{569}$ Editorial da janela que instrumentaliza o acesso às pautas e atas das reuniões deliberativas do Conselho Diretor da ANATEL e aos votos e análises de seus conselheiros. Disponível em http://www.anatel.gov.br/Portal/exibirPortalInternet.do. Acesso em 30 de novembro de 2011.
} 
segurança da sociedade e do Estado, justificados em decisão fundamentada pela Agência Reguladora $\left(\operatorname{art.} 1^{\circ}\right)$. O acesso integral a esses processos não poderá, entretanto, ser obstado aos interessados, reservando-se a parcela de dados e documentação sigilosa (arts. $2^{\circ}$ e $3^{\circ}$ ).

Repise-se, de plano, que tal norma decorreu diretamente de sentença judicial; o que nos leva a crer que se essa decisão do Poder Judiciário não existisse a ANATEL continuaria a não possibilitar o acesso aos autos dos PADOs em qualquer fase processual, tal como vem atuando nos últimos 14 anos.

Veja-se, ainda, que o acesso aos processos administrativos de outra espécie, tal qual os de anuência prévia estudados na PARTE II, Capítulo III da dissertação, da mesma forma, não estão abrangido pela Portaria n. ${ }^{\circ}$ 941/2011. Estes permanecem, assim, com acesso incerto e imprevisível junto à ANATEL, como relatamos acima.

Um último comentário a respeito da Portaria n. ${ }^{\circ}$ 941/2011refere-se ao procedimento eletrônico de obtenção de vistas e cópias de processos administrativos e documentos, realizado por meio do site da ANATEL, aplicável aos PADOs, conforme o art. $5^{\circ}$ da norma. Este procedimento, como alertamos acima, acaba por obstar o acesso do público em geral aos processos e documentos da Agência Reguladora. Especificamente no caso dos processos, o sistema eletrônico, corroborado pelos funcionários da Biblioteca da ANATEL, limita o acesso aos autos exclusivamente aos procuradores das partes envolvidas. Por essa razão, questionamos como se disponibilizará o efetivo acesso aos PADOs a todos os interessados através de um sistema que, per se, é restritivo?

A Portaria n. ${ }^{\circ}$ 982/2011, por sua vez, determinou que os sorteios para distribuição entre os conselheiros dos temas e casos concretos a serem decididos pela ANATEL e as próprias reuniões deliberativas do Conselho Diretor da Agência Reguladora seriam, a partir de 24 de novembro de 2011, transmitidos por meio de telão instalado no miniauditório da sede da ANATEL, localizado no $2^{\circ}$ andar do Edifício Luiz Eduardo Magalhães em Brasília, em tempo real e aberta ao público em geral. Para a preservação de dados protegidos por Lei e pela Constituição Federal, referida transmissão poderia ser restringida (art. $1^{\circ}$ e parágrafos).

A respeito da Portaria n. ${ }^{\circ}$ 982/2001 é preciso comentar que essa não trata da possibilidade de participação e intervenção oral dos interessados nas deliberações do 
Conselho Diretor, tal como já previsto no art. $8^{\circ}, \S 3^{\circ}$ Regimento Interno em vigor, mas sem aplicação na prática.

Também não se menciona a obrigatoriedade de publicação das Atas das reuniões deliberativas e das Análises e Votos dos conselheiros da Agência Reguladora, também já prevista no art. 15, VII do Regimento Interno em vigor e não atendida pela grande maioria dos conselhos que passaram e que estão na ANATEL nos dias atuais.

Contudo, o Presidente da ANATEL, João Batista de Rezende, por ocasião de sua posse, em 07 de novembro de 2011, afirmou ao apresentar a Portaria n. ${ }^{\circ}$ 982/2011, que as Análises e Votos dos conselheiros seriam publicados no site da Agência Reguladora após as reuniões do seu Conselho Diretor. ${ }^{570}$

Da mesma forma, Portaria n. ${ }^{\circ}$ 982/2011 não dispõe sobre a disponibilização de estudos, pareceres, informes e outros documentos produzidos pelas áreas técnicas da ANATEL ou por terceiros contratados pela Agência Reguladora para embasar suas decisões.

É, por tais ausências, que reputamos bastante limitado o objeto da referida portaria.

Não obstante, o Presidente da ANATEL, na mesma ocasião de sua posse, sustentou que, em 2012, será colocada em consulta pública proposta de alterações no Regimento Interno da Agência Reguladora e que as mudanças propostas permitiriam a participação e intervenção oral dos interessados nas reuniões do Conselho Diretor e a publicação por meio de links nas atas dessas reuniões das Análises e Votos dos conselheiros, o que dispensaria a sua publicação em separado no site da ANATEL. ${ }^{571}$

Embora louváveis essas iniciativas, a realidade é de dificílima transformação em razão do hábito da falta de transparência consolidado na ANATEL. Basta checar alguns dados disponíveis no próprio site da Agência Reguladora.

Um exemplo é contundente e bastante nítido do que queremos dizer. $\mathrm{O}$ atual Presidente da Agência Reguladora, João Batista de Rezende, que frisou com acalorada

\footnotetext{
570 "Abertura das Reuniões do Conselho Diretor da ANATEL”, disponível http://www.anatel.gov.br/Portal/exibirPortalInternet.do. Acesso em 08/11/2011.

571 "Abertura das Reuniões do Conselho Diretor da ANATEL", disponível em http://www.anatel.gov.br/Portal/exibirPortalInternet.do. Acesso em 08/11/2011.
} 
convicção a necessidade de se implementar a transparência na ANATEL, ao anunciar oficialmente as medidas ora tratadas, publicou no site da Agência Reguladora, no período de 20 de janeiro a 01 de dezembro, tão-somente 04 Análises de sua autoria e nenhum Voto que proferiu. $^{572}$ É certo que nesse período foram pautadas 39 reuniões deliberativas ${ }^{573}$, sendo que em cada uma delas diversos casos foram julgados e, certamente, em mais de 04 oportunidades o Presidente da ANATEL exerceu funções de relatoria e manifestou seu voto.

Esse exemplo é ainda mais contundente se compararmos o nível de transparência entre os próprios conselheiros da ANATEL.

A conselheira Emilia Maria Silva Ribeiro, por exemplo, no mesmo período analisado, publicou no site da Agência Reguladora 374 Análises e 17 Votos apartados. ${ }^{574}$

Esses exemplos conjugados com os comentários apresentados acima se prestam a comprovar dois pontos. Um que a transparência da ANATEL antes das medidas anunciadas, era muito baixa. E outro que há um longo caminho a percorrer para que se chegue a um grau razoável de transparência da Agência Reguladora.

Não obstante, é preciso reconhecer que as transmissões audiovisuais das reuniões do Conselho Diretor da ANATEL se iniciaram e que o site da Agência Reguladora efetivamente contém as suas gravações, o que já é um grande avanço ao cenário anterior.

É nesse contexto, pois, que apresentamos a transparência, como dever de a ANATEL dar a conhecer todas as suas atividades e opções, a qualquer tempo, e atos e processos, em formação, em andamento, concluídos e arquivados, como parâmetro concreto e objetivo para a aferição da correção das decisões discricionárias da Agência Reguladora.

\footnotetext{
572 Informação disponível em http://www.anatel.gov.br/Portal/exibirPortalInternet.do. Acesso em 30 de novembro de 2011. São essas as Análises publicadas pelo Presidente da ANATEL: Análise n. ${ }^{\circ}$ 195/2011-JR, de 24/03/2011; Análise 295/2011-JR, de 12/05/2011; Análise n. ${ }^{\circ}$ 487/2011-JR, de 15/07/2011; e Análise n. ${ }^{\circ}$ 870/2011-JR, de 21/10/2011.

${ }^{573}$ Informação disponível em http://www.anatel.gov.br/Portal/exibirPortalInternet.do. Acesso em $30 \mathrm{de}$ novembro de 2011.

574 Informação disponível em http://www.anatel.gov.br/Portal/exibirPortalInternet.do. Acesso em 30 de novembro de 2011.
} 


\section{5. 4. A Efetividade da Decisão Regulatória Discricionária e o Prognóstico da sua Efetividade.}

$\mathrm{O}$ quarto e último parâmetro concreto e objetivo que propomos para o acompanhamento pelos interessados dos processos decisórios da ANATEL e para o eventual cotejo judicial das decisões regulatórias discricionárias desses decorrentes é o teste da efetividade e do prognóstico da sua efetividade.

O parâmetro proposto é guiado pelo seguinte questionamento:

\section{A decisão regulatória discricionária é efetiva?}

A resposta a esse questionamento passa, então, por se compreender o que entendemos por efetividade e, bem assim, como essa seria apurada in concreto nas decisões regulatórias discricionárias.

Antes, porém, é preciso demarcar que esse questionamento teria aplicação em dois momentos: um contemporâneo ao proferimento da decisão regulatória discricionária, aferindo-se a sua correção imediata e outro prospectivo, projetando-se os seus efeitos no tempo.

É dizer, assim, que a efetividade da decisão regulatória discricionária, nos casos de mediação ativa de interesses, deveria ter seu equilíbrio testado para o momento em que essa é proferida (como óbvio), com a avaliação da ordem de prevalências dos interesses contrapostos e da intensidade dessa prevalência ${ }^{575} \mathrm{e}$, também, prospectivamente, examinando-se se o equilíbrio estabelecido entre as prevalências remanesceria, em um curso provável, no futuro.

É Diogo de Figueiredo MOREIRA NETO que apresenta a medida da efetividade ora adotada como referencial para as decisões regulatórias discricionárias no presente e no futuro. O jurista explica que a efetividade da ação administrativa é a medida de sua eficiência e que considera a real produção dos efeitos visados pela autoridade pública. $^{576}$

Cumpre-nos, assim, realizar uma brevíssima digressão acerca da eficiência da Administração Pública, com vistas a esclarecer quais efeitos da decisão regulatória

\footnotetext{
${ }^{575}$ Cf. Robert ALEXY. Teoria dos Direitos Fundamentais, p. 144 e ss.

${ }^{576}$ Mutações de Direito Administrativo, p. 32-33.
} 
discricionária atenderiam ao parâmetro da efetividade e do prognóstico da efetividade, isto é, qual o padrão referencial da decisão regulatória discricionária que deve ser buscado no presente para que seja refletido no futuro apropriadamente.

Como se sabe a emenda constitucional n. ${ }^{\circ}$ 19/1998 acrescentou o princípio da eficiência aos princípios da Administração Pública, enunciados no art. 37, caput, da Constituição Federal. ${ }^{577}$

Paulo MODESTO observa, todavia, que antes mesmo da introdução expressa do princípio da eficiência na Constituição Federal brasileira, esse não era desconhecido. Ao contrário, já era tratado pela doutrina pátria e reconhecido pelos tribunais. ${ }^{578}$

Adilson Abreu DALLARI e Sérgio FERRAZ anotam acerca do novo panorama constitucional que:

$$
\begin{aligned}
& \text { “O propósito fundamental da reforma \{referem-se à } \\
& \text { reforma administrativa] era a substituição do antigo modelo } \\
& \text { burocrático, caracterizado pelo controle rigoroso dos } \\
& \text { procedimentos pelo novo modelo gerencial, no qual são } \\
& \text { abrangidos os controle de procedimentos e incrementados } \\
& \text { os controles de resultados. }
\end{aligned}
$$

A eficiência passa a representar, desta feita, um parâmetro abstrato à atuação administrativa (como vimos acima, a efetividade é o parâmetro concreto), com base na qual se torna possível o controle dos resultados do agente público e não mais apenas o controle do agir administrativo. ${ }^{580}$

\footnotetext{
577 Antes, porém, a legislação pátria já possuía esse conceito, tal qual na Lei Orgânica do Município de São Paulo e na Lei n. ${ }^{\circ} 8.987 / 1995$.

${ }_{578}^{578}$ Notas para um Debate sobre o Princípio Constitucional da Eficiência, p. 4-5.

${ }^{579}$ Processo Administrativo, p. 77.

580 Entendemos que a novidade decorrente da expressa previsão do princípio da eficiência na Constituição Federal diz respeito exatamente à ampliação dos meios de controle da Administração Pública; a partir daquele momento possível, também através de seus resultados, e não propriamente no seu dever de agir de modo eficiente que, a nosso ver, já existia. Lucia Valle FIGUEIREDO é taxativa: “(...) à Administração Pública sempre coube agir com eficiência em seus cometimentos”. Curso de Direito Administrativo, p. 63. Paulo MODESTO sustenta acertadamente, também, a esse respeito que: "Nunca houve autorização constitucional para uma administração pública ineficiente. A boa gestão da coisa pública é obrigação inerente a qualquer exercício da função administrativa e deve ser buscada nos limites estabelecidos pela lei. A função administrativa é sempre função finalista, exercida em nome e em favor de terceiros, razão pela qual exige legalidade, impessoalidade, moralidade, responsabilidade, publicidade e transparência de seus exercentes.". Anote-se, ademais, que o autor também não vê na introdução constitucional do controle de resultados uma "inovação absoluta". Notas para um Debate sobre o Princípio Constitucional da Eficiência, p. 7.
} 
Diante desse novo panorama constitucional esses autores afirmam ainda que:

"Não basta ao administrador demonstrar que agiu bem, em
estrita conformidade com a lei, sem se divorciar da
legalidade (que não se confunde com a estrita legalidade),
cabe a ele evidenciar que caminhou no sentido da obtenção
dos melhores resultados."

A eficiência como diretriz da Administração Pública brasileira é associada, assim, a uma administração de resultados ${ }^{582} \mathrm{em}$ que o agir administrativo mandatoriamente deve articular-se até a efetiva realização dos resultados almejados no ordenamento jurídico. ${ }^{583}$

A doutrina administrativista pátria ressalta, ademais, que o dever de eficiência estatal incorporado à ordem jurídica brasileira corresponde ao dever de boa administração ${ }^{584}$ cunhado na doutrina italiana. ${ }^{585}$

No direito brasileiro, comumente, atribui-se à eficiência duas dimensões básicas $^{586}$, uma referente à racionalização e maximização do uso de recursos públicos e

${ }^{581}$ Cf. Adilson Abreu DALLARI e Sérgio FERRAZ. Processo Administrativo, p. 78.

582 Para uma introdução ao tema ver Diogo de Figueiredo MOREIRA NETO. Quatro Paradigmas do Direito Administrativo Pós-Moderno: Legitimidade - Finalidade - Eficiência - Resultados.

583 Acerca da compatibilização do princípio da eficiência com o princípio da legalidade dois são os posicionamentos doutrinários: um no sentido de que os meios para a obtenção dos resultados devem estar absolutamente em consonância com a legalidade em sentido amplo (juridicidade) e, outro que admite que regras menores podem ser preteridas com vistas ao atingimento maior da finalidade legal. A esse respeito ver O Princípio da Eficiência de Alexandre Santos de ARAGÃO, p. 75-80.

${ }^{584}$ No direito brasileiro, ao longo dessa dissertação, já fizemos referência a excelente obra de Juarez FREITAS. O autor assim explica o conceito de boa administração pública: “(...) administração pública eficiente e eficaz, proporcional cumpridora de seus deveres, com transparência, motivação, imparcialidade e respeito à moralidade, à participação social e à plena responsabilidade por suas condutas omissivas e comissivas." Discricionariedade Administrativa e o Direito á Boa Administração Pública, p.22.

${ }^{585}$ Maria Sylvia Zanella DI PIETRO. Direito Administrativo, p. 79. Celso Antonio BANDEIRA DE MELlO. Curso de Direito Administrativo, p. 122. Diogo de Figueiredo MOREIRA NETO assim esclarece a origem do princípio da eficiência no direito brasileiro. "De outro lado, destaca-se a sua origem em estudos jurídicos doutrinários de vanguarda, desenvolvidos desde meados do século XX, por juristas de porte de Raffaele Resta e Guido Falzone, no sentido de superar o conceito de poder-dever de administrar, afirmado pela administração burocrática, empenhada apenas em lograr a eficácia, para estabelecer, como um passo adiante, o dever da boa administração, respaldado pelos conceitos gerenciais voltados á eficiência da ação administrativa pública." (grifos no original). Mutações de Direito Público, p. 310. Paulo Modesto anota que no direito comparado o tema da eficiência é ainda tratado como o princípio da eficácia, princípio da racionalização jurídica e economicidade. Notas para um Debate sobre o Princípio Constitucional da Eficiência, p. 3.

586 Juarez FREITAS apresenta posicionamento peculiar. O autor retrata essas dimensões como princípios distintos: princípio da economicidade (vedação ao desperdício) e princípio da eficiência (vedação dos meios inapropriados). Associando-os, ainda, ao princípio da eficácia (vedação do descumprimento dos objetivos ou metas constitucionais). Controle dos Atos Administrativos, p. 125. 
outra atinente à qualidade da ação administrativa para a obtenção de resultados satisfatórios, senão excelentes. ${ }^{587}$

Alexandre de MORAES apresenta conceito que comporta a ambas as dimensões mencionadas:

\begin{abstract}
"Assim, princípio da eficiência é o que impõe à Administração Pública direta e indireta e a seus agentes a persecução do bem comum, por meio do exercício de suas competências de forma imparcial, neutra, transparente, participativa, eficaz, sem burocracia e sempre em busca da qualidade, primando pela adoção de critérios legais e morais necessários para a melhor utilização possível de recursos públicos, de maneira a evitar desperdícios $e$ garantir uma maior rentabilidade social." ${ }^{588}$ (grifos nossos)
\end{abstract}

A efetividade, conquanto medida concreta da eficiência, no contexto deste trabalho, é tomada em sua segunda dimensão, ou seja, a de busca de soluções qualitativamente satisfatórias, excelentes.

A aplicação da eficiência na mediação ativa de interesses, como propomos, apresenta-se, assim, sob a faceta da compatibilização ótima dos interesses legítimos contrapostos ou, quando impossível a sua compatibilização, do equilíbrio ideal entre a prevalência de um e o sacrifício do outro. Esses seriam, pois, os efeitos da decisão regulatória discricionária que atenderiam ao parâmetro da efetividade.

Celso Antonio BANDEIRA DE MELLO pontua que a existência da discricionariedade fundamenta-se no fato de que a intenção da lei é, justamente, a de obter, graças à outorga dessa liberdade à Administração Pública, a solução mais conveniente para os interesses que se propôs curar. ${ }^{589}$ Para o autor,

"Se não fosse seu intuito assegurar, nos casos concretos a solução que atendesse com exata perfeição a seus objetivos, haveria regulado diversamente a matéria. É a certeza de que os objetivos almejados, para serem efetivamente

${ }^{587}$ Acerca do tema ver o artigo de Humberto ÁVILA. Moralidade, Razoabilidade e Eficiência na Atividade Administrativa, p. 19 e ss.

${ }_{588}$ Princípio da Eficiência e Controle Jurisdicional dos Atos Administrativos Discricionários, p. 22.

${ }^{589}$ Grandes Temas de Direito Administrativo, p. 160. 
atendidos in concreto, dependeriam de um juizo mais acertado das circunstâncias fáticas aquilo que leva a lei em nome destes mesmos objetivos - a deferir discricionariedade. ${ }^{590}$ (negrito no original)

Como consequiência lógica da relação direta entre discricionariedade-solução mais conveniente in concreto, extrai o autor que é dever jurídico da Administração Pública, necessariamente, escolher a melhor solução ao caso concreto como corolário do dever jurídico de boa administração. ${ }^{591}$

Nessa ordem de convicções, o regulador passaria, assim, a ter o dever de procurar, diante das circunstâncias de cada caso concreto e dentre as alternativas possíveis, a melhor solução (ou a solução ótima, como afirma Gustavo BINEMBOJM) ${ }^{592}$ para os interesses em jogo de acordo com o padrão referencial de efetividade esperado (compatibilização ótima ou equilíbrio ideal). ${ }^{593}$

De fato, como anota Robert ALEXY, os sopesamentos não são uma questão de tudo ou nada, mas uma tarefa de otimização ${ }^{594}$ ou de concordância prática, tal como afirma Konrad HESSE. ${ }^{595}$

Trata-se de se estabelecer um mecanismo de concessões recíprocas em que se alcance, senão a compatibilização de todos os interesses em conflito, a satisfação do interesse prevalecente, com o mínimo sacrifício dos demais. ${ }^{596}$

\footnotetext{
${ }^{590}$ Grandes Temas de Direito Administrativo, p. 160.

591 Afirma ainda o autor que em contraponto ao dever de boa administração, ou seja, da escolha mais adequada de acordo com a finalidade da lei, encontra-se o direito subjetivo do administrativo de que a providência administrativa incidente sobre ele esteja ajustada a esses parâmetros. Sustenta Celso Antonio BANDEIRA DE MELLO a esse respeito que se a decisão administrativa não estiver em consonância com os parâmetros legais, poderá ter sonegado ao administrado uma vantagem que - ante o caso concreto - a lei pretendia lhe fosse deferida, ou ter-lhe imputado um gravame que a lei não desejava lhe fosse irrogado. Celso Antonio BANDEIRA DE MELLO. Grandes Temas de Direito Administrativo, p. 160 e ss.

592 Da Supremacia do Interesse Público ao Dever de Proporcionalidade: Um Novo Paradigma para o Direito Administrativo, p. 21.

${ }^{593}$ No contexto regulatório especificamente, Marcos Juruena Villela SOUTO afirma que considerando que as decisões regulatórias exigem uma ponderação de interesses que envolve o Poder Público, o consumidor e o fornecedor de bens e serviços, esses atos devem ser exarados com vistas ao atingimento de seu "ponto ótimo”. Direito Regulatório, p. 58.

${ }_{594}$ Teoria dos Direitos Fundamentais, p. 173

595 Apud Robert ALEXY. Teoria dos Direitos Fundamentais, p. 173

${ }^{596}$ A esse respeito vale a pena trazer as palavras de Gustavo BINENBOJM: “(...) sempre que a própria Constituição ou a lei (desde que agindo constitucionalmente) não houver esgotado os juízos possíveis de ponderação entre interesses públicos e privados, caberá à Administração lançar mão da ponderação de todos os interesses e atores envolvidos na questão, buscando a sua máxima realização.” (grifos nossos) Da
} 
Essa técnica de ponderação propiciaria, como observa Gustavo BINENBOJM, uma forma de controle da discricionariedade administrativa e da racionalização dos processos de definição do interesse prevalecente. ${ }^{597}$

Destaque-se que o raciocínio ponderativo diz perfeitamente com o atual estágio do Estado Contemporâneo em que se reconhece a existência de uma pluralidade de interesses legítimos em conflito e, bem assim, que não há um interesse público que, de antemão e automaticamente, se sobreponha a todos os demais, como vimos em nosso Capítulo I.

Avaliar, contudo, se a decisão regulatória discricionária atende à compatibilização ótima ou ao equilíbrio ideal de satisfação e sacrifico entre os interesses dos regulados objeto de mediação regulatória, exige a definição de critérios específicos que permitam a sua verificação in concreto. ${ }^{598}$

Diante, pois, de um exercício de ponderação de interesses legítimos (inerente a sua mediação ativa), encontramos esses critérios, quase que intuitivamente, nos elementos que expressam, em concreto, a aplicação da proporcionalidade (em sentido amplo) nos processos decisórios, isto é, na exigência de que as ações da autoridade pública se realizem com base na necessidade, na adequação e na proporcionalidade (em sentido estrito). ${ }^{599}$

É que, como afirma Daniel SARMENTO, a proporcionalidade é o instrumento da ponderação. ${ }^{600}$

Supremacia do Interesse Público ao Dever de Proporcionalidade: Um Novo Paradigma para o Direito Administrativo, p. 20.

${ }^{597}$ Da Supremacia do Interesse Público ao Dever de Proporcionalidade: Um Novo Paradigma para o Direito Administrativo, p. 21.

${ }^{598}$ Diogo de Figueiredo MOREIRA NETO afirma, no mesmo sentido, que para a aferição de que os atos administrativos lograram o melhor atendimento possível é preciso que se assentem parâmetros objetivos para a aferição de resultados. Para o autor, com quem concordamos, esses parâmetros jamais poderiam ser subjetivos. Mutações de Direito Público, p. 311.

${ }^{599}$ Robert ALEXY destaca, igualmente, que a máxima da otimização está diretamente relacionada à máxima da proporcionalidade, expressa em suas máximas parciais, adequação, necessidade e proporcionalidade. Teoria dos Direitos Fundamentais, p. 588. Odete MEDAUAR destaca que, no ordenamento jurídico alemão, o controle da discricionariedade é realizado pelo juiz com base na aplicação do princípio da proporcionalidade com a seguinte aferição: “(a) se a medida tomada pela autoridade administrativa é suscetível de alcançar o objetivo pretendido (princípio da adequação; (b) se a medida é necessária, isto é, se nenhuma medida menos grave permitiria obter o resultado (princípio da necessidade); (c) se a medida for adequada e necessária, verifica se há ou não severidade exagerada em relação ao fim pretendido, isto é, se há desproporção entre meio e fim (princípio da proporcionalidade em sentido estrito)”. Direito Administrativo em Evolução, p. 200.

${ }^{600}$ A Ponderação de Interesses na Constituição Federal, p. 96. 
De fato, poder-nos-ia ser indagado se não nos valeríamos, assim, de critérios subjetivos e abstratos, próprios dos princípios jurídicos, e, nessa medida, nossa crítica acerca do uso dos princípios gerais do direito, como parâmetros para o controle das decisões regulatórias discricionárias, nos seria, igualmente, aplicada.

É um risco que corremos; embora, entendamos com Humberto ÁVILA ${ }^{601}$ e Robert $\mathrm{ALEXY}^{602}$, que a proporcionalidade não encerra em si um princípio. Ademais, os seus elementos possibilitam aferir objetivamente se a ação administrativa buscou a compatibilização ótima ou ao equilíbrio ideal de satisfação e sacrifico entre os interesses dos regulados. Isto é, se a efetividade é a medida concreta da eficiência, temos conosco que a adequação, a necessidade e a proporcionalidade em sentido estrito compõem a medida concreta da proporcionalidade (em sentido amplo) e, pois, seriam auferíveis objetivamente na casuística da ANATEL.

Pois bem. A proporcionalidade (em sentido amplo) é largamente abordada na doutrina administrativista, nacional e estrangeira, comumente sob a forma de princípio. ${ }^{603}$ Não nos alongaremos em seus termos, pois, não é esse o objeto de nosso trabalho. Contudo, uma vez que iremos nos valer de seus elementos de expressão concreta, cumpre-nos apresentá-los, com vistas a orientar o raciocínio seguinte.

A adequação do agir administrativo diz com a conformação entre a medida adotada e as finalidades buscadas com a sua adoção, ou seja, a ação da autoridade pública deve ser apta ao atingimento dos fins por essa visados. Adequação medida-fim. ${ }^{604}$ Robert ALEXY anota, ainda, que a máxima da adequação é um critério negativo, que permite identificar os meios não adequados às finalidades buscadas. ${ }^{605}$

\footnotetext{
${ }^{601}$ Para Humberto ÁVILA, a proporcionalidade é um postulado normativo aplicativo, pois impõe uma condição formal ou estrutural de conhecimento concreto (aplicação) das normas. A Distinção entre princípios e Regras e a Redefinição do Dever de Proporcionalidade, p.168 e ss.

${ }^{602}$ Para Robert ALEXY, a proporcionalidade é uma máxima e não um princípio, pois não entra em conflito com outros princípios, não é concretizado em vários graus ou aplicado mediante a criação de regras de prevalência diante do caso concreto.Teoria dos Direitos Fundamentais, p. 100.

${ }^{603}$ Sobre o tema ver: Alexandre Santos de ARAGÃO. O Princípio da Proporcionalidade no Direito Econômico. Sérgio GUERRA. O Princípio da Proporcionalidade na Pós-Modernidade. Gustavo BINENBOJM. Da Supremacia do Interesse Público ao Dever de Proporcionalidade: Um Novo Paradigma para o Direito Administrativo. Floriano de Azevedo MARQUES NETO. Limites à Abrangência e à Intensidade da Regulação Estatal. E do mesmo autor, Princípios da Proporcionalidade e da Legalidade na Regulação Estatal.

${ }^{604}$ Cf. Sérgio GUERRA. O Princípio da Proporcionalidade na Pós-Modernidade, p. 190.

605 Teoria dos Direitos Fundamentais, p. 590.
} 
A necessidade ou exigibilidade corresponde à medida que não pode exceder aos limites indispensáveis à conservação do fim legítimo que se pretende alcançar, isto é, dentre dois meios adequados, deve-se escolher aquele que intervenha de modo menos intenso no interesse não atendido. Busca do meio mais suave. ${ }^{606}$

A proporcionalidade em sentido estrito atine à constatação de que o resultado obtido com o ato estatal é proporcional à 'carga coactiva'. Correspondência meio e fim. ${ }^{607}$ $\mathrm{Ou}$, nas palavras de J.J. CANOTILHO, justa medida ${ }^{608} \mathrm{~A}$ proporcionalidade em sentido estrito, nessa perspectiva, reflete a Lei do Sopesamento de Robert ALEXY ${ }^{609}$ aplicada à mediação ativa de interesses, de modo que diante da impossibilidade de compatibilização de todos os interesses discutidos no caso concreto, ao maior grau de não-satisfação ou de afetação de um interesse deve corresponder a importância da satisfação do outro. ${ }^{610}$

Com base nessas noções, propomos que as decisões regulatórias discricionárias da ANATEL sujeitem-se ao teste da proporcionalidade (em sentido amplo) apto a identificar o padrão referencial buscado para a comprovação de sua efetividade. ${ }^{611}$ Esse teste poderia ser realizado pelo próprio regulador, ou ainda, pelos interessados no acompanhamento do processo decisório da Agência Reguladora e pelo Poder Judiciário diante da necessidade de exercer seu controle sobre as decisões regulatórias discricionárias da ANATEL.

O teste seria guiado por quatro questões básicas, divididas em dois momentos:

Em um primeiro momento, em busca da compatibilização de todos os interesses contrapostos, cumpriria indagar:

(i) É possível a compatibilização dos interesses contrapostos?

\footnotetext{
${ }^{606}$ Cf. Sérgio GUERRA. O Princípio da Proporcionalidade na Pós-Modernidade, p. 190.

${ }^{607}$ Cf. Sérgio GUERRA. O Princípio da Proporcionalidade na Pós-Modernidade, p. 190.

${ }^{608}$ Direito Constitucional e Teoria da Constituição, p. 270.

${ }^{609}$ Teoria dos Direitos Fundamentais, p. 167.

${ }^{610}$ Teoria dos Direitos Fundamentais, p. 593.

${ }^{611}$ Floriano de Azevedo MARQUES NETO afirma que “(...) o princípio da proporcionalidade é central e fundamental quando estamos diante do exercício da atividade regulatória estatal. De um lado, porque se trata de atividade estatal que implica, por definição, em alguma restrição do princípio de liberdade de iniciativa. De outro, porque a regulação, especialmente quando exercida por agências independentes, envolve a transferência de significativos poderes a um só órgão, obrigando o conseqüente reforço no condicionamento e adstrição aos princípios limitadores do poder extroverso.”. Princípios da Proporcionalidade e da Legalidade na Regulação Estatal, p. 382.
} 
Em caso positivo, revela-se o dever do regulador de compatibilizar todos os interesses em jogo.

Em caso negativo, em um segundo momento, buscar-se-ia o equilíbrio ideal dos interesses em jogo e, para tanto, aplicar-se-iam as questões subsequentes:

(ii) $\mathrm{O}$ estabelecimento de uma ordem de prevalências entre os interesses em jogo possibilita o atendimento da legislação e da regulamentação setorial (questão da adequação)?

(iii) Atendida à adequação à legislação e à regulamentação setorial e, estabelecida a ordem de prevalências entre os interesses em jogo, existe outra solução menos gravosa aos interesses não atendidos (questão da necessidade)?

(iv) A relação entre o benefício gerado com a satisfação de um interesse e o sacrifício de outro possui correspondência direta de grandezas (questão da proporcionalidade)?

As respostas possíveis ao segundo bloco de questionamentos poderiam ser ilustradas da seguinte forma:

\begin{tabular}{|c|c|c|}
\hline ADEQUAÇÃO & NECESSIDADE & PROPORCIONALIDADE \\
\hline+ & + & + \\
\hline+ & + & - \\
\hline+ & - & $/$ \\
\hline- & $/$ & $/$ \\
\hline
\end{tabular}

A primeira hipótese apresenta a decisão regulatória discricionária que se comprovasse necessária, adequada e proporcional. Seria o equilíbrio ideal (sombreado na tabela) e, portanto, a solução desejada e esperada para o caso concreto. Em existindo a 
possibilidade de sua aplicação e não sendo esta a solução aplicada pelo regulador ao caso concreto, no mais das vezes, poder-se-ia afirmar que se estaria diante de uma decisão regulatória arbitrária por constatação de uma das outras hipóteses apresentadas nas linhas seguintes da tabela apresentada.

A segunda hipótese retrata a decisão regulatória discricionária que se revelasse necessária, adequada, mas desproporcional, isto é, que causasse alguma forma de prejuízo injustificado, porquanto excessivo, aos interesses não atendidos pelo regulador. É dizer que somente é justificável e, pois, não arbitrário, o sacrifício de um interesse legítimo na exata medida necessária para a satisfação do interesse prevalecente. Afora disso, o regulador atua sem amparo no ordenamento jurídico.

Essa hipótese representa, no mais das vezes, as situações arbitrárias constatadas junto às Agências Reguladoras. Especificamente com relação à ANATEL, pudemos inferir de nosso estudo de casos, apresentado no Capítulo III, que as decisões regulatórias discricionárias da Agência Reguladora podem ter sido desproporcionais, uma vez que não vislumbramos equivalência entre a carga de condicionamentos e contrapartidas (sacrifícios) impostos às partes envolvidas nas operações e os benefícios ao mercado e à sociedade decorrentes dessas cominações.

A terceira hipótese ilustrada a decisão regulatória que se mostra adequada, mas não necessária, isto é, atenderia ao cumprimento da legislação e regulamentação setorial, mas existiriam outros meios menos gravosos para tal fim. Assim, a solução regulatória seria arbitrária, pois não necessária diante do caso concreto e, nessa medida, não faria sentido apurar a sua proporcionalidade.

A quarta hipótese demonstra a decisão regulatória que, de plano, se evidencia inadequada para o atendimento da legislação e regulamentação setorial; logo, se não adequada e aplicada, há evidente arbitrariedade do regulador. Nesse caso, por óbvio, não haveria sentido se perquirir a necessidade e a proporcionalidade da decisão regulatória.

Assim, diante da mediação ativa de interesses contrapostos, a decisão regulatória discricionária mostrar-se-ia não arbitrária se (i) fosse apta ao atendimento da legislação e regulamentação setorial; e (ii) representasse a solução menos gravosa ao interesse não atendido; e (iii) o benefício logrado com a prevalência de um interesse correspondesse à exata medida do sacrifício do interesse não atendido. 
Veja-se que se tratam de critérios concretos cumulativos e apenas a constatação dos três comprova a efetividade da decisão regulatória discricionária. Em outras palavras, a inadequação, a ausência de necessidade e a desproporcionalidade da decisão regulatória discricionária indicariam potencial arbitrariedade do regulador.

Esclarecido, assim, o padrão referencial da efetividade a ser buscado na casuística da ANATEL (a compatibilização ótima e o equilíbrio ideal entre os interesses contrapostos) e como aferi-lo em concreto por meio do teste da proporcionalidade, cumpre-nos tratar do prognóstico da efetividade.

Como dissemos no início deste item, a efetividade das decisões regulatórias discricionárias deve ser comprovada, não só no momento de seu proferimento, mas também prospectivamente, considerando um curso provável dos acontecimentos.

Em outras palavras, a compatibilização ótima e o equilíbrio ideal dos interesses contrapostos a ser buscada pela ANATEL devem ser também realidade no futuro.

O dever de as Agências Reguladoras atuarem concertando às situações no presente e pautando os efeitos futuros de suas ações não é novidade.

Sérgio GUERRA a esse respeito já observou que:

“A regulação exercida pelas Agências Reguladoras deve ser implementada por meio de uma interpretação prospectiva, para o futuro. Esse aspecto, que sempre deve estar presente na orientação do agente regulador, pondera custos benefícios e impactos da ação regulatória no subsistema a ele afeto" 612

É que, ao longo do tempo, as ações, opções e decisões do regulador podem deixar de atender aos interesses em que foram tomadas ou podem resultar em um desequilíbrio na ordem e na intensidade da prevalência de interesses fixadas pelo regulador. $^{613}$

Por exemplo, a restrição à competição em um determinado mercado para a consolidação e fortalecimento dos players nesse atuante, pode se revelar, com o passar dos

${ }^{612}$ Controle Judicial dos Atos Regulatórios, p. 263-264.

${ }^{613}$ Cf. Robert ALEXY. Teoria dos Direitos Fundamentais, p. 144 e ss. 
anos, uma reserva de mercado indesejada pelo regulador, que impeça a entrada de novos competidores e estanque a evolução dos serviços e das ofertas aos usuários.

Não é de estranhar que os custos, benefícios e impactos da ação regulatória nos subsistemas regulados variem ao longo do tempo na era da velocidade $e$ do pragmatismo $^{614}$. Isto é, que a razão entre os fatores sopesados pelo regulador, por ocasião de uma mediação ativa de interesses, não permaneça estática em um mundo tão dinâmico.

Diogo de Figueiredo MOREIRA NETO, assim, registra a tarefa do regulador:

"Para motivar se determinada decisão administrativa é ou não aquela considerada justa para a hipótese é necessário, na perspectiva do Direito Contemporâneo, não apenas que a justificativa seja retrospectiva, levando em conta dados do passado, mas que sejam considerados também elementos justificativos voltados para o futuro, através de um exercício prospectivo, de modo a ser possível demonstrar que as soluções adotadas, uma vez aplicadas, não comprometerão outros valores que mereçam ser salvaguardados ou, pelo menos, que farão em nível proporcionalmente tolerável em relação a esses valores fundamentais, que a própria ordem jurídica declara e preserva." ${ }^{615}$ (grifos nossos)

Significa dizer, desta feita, que cumpre ao regulador aferir se a decisão regulatória discricionária a ser proferida produzirá exatamente os efeitos que se pretende no momento de seu proferimento e no futuro, isto é, impende-lhe vislumbrar quais são as prováveis consequências de sua decisão, o que não envolve apenas as partes envolvidas, mas todos aqueles que serão por essa serão atingidos direta e indiretamente.

Revela-se, assim, de especial relevância que ao decidir o regulador avalie e demonstre os efeitos de sua decisão no presente e projete suas conseqüências em um futuro provável, prognosticando a efetividade da decisão regulatória no tempo.

${ }^{614}$ A expressão é de Luís Roberto BARROSO. A Segurança Jurídica na Era da Velocidade e do Pragmatismo, p. 52-64.

${ }^{615}$ Direito Regulatório, p. 101-102. 
O parâmetro concreto e objetivo que ora propomos encerra, portanto, a busca da compatibilização ótima e do equilíbrio ideal dos interesses em jogo nos processos decisórios da ANATEL e sua efetividade no presente e em um futuro provável.

\section{6. Conclusões.}

A flexibilidade inerente às Agências Reguladoras - imprescindível para o bom cumprimento de suas funções marcadamente especializadas - pressupõe ampla margem de liberdade ao regulador no processo formativo das decisões regulatórias discricionárias. Assim é nos casos de mediação ativa de interesses legítimos.

A discricionariedade do regulador não legitíma, entretanto, a prática de decisões regulatórias arbitrárias, desencontradas com as finalidades legais e capturadas por grupos de interesses.

Reafirma-se, contemporaneamente, a qualidade de liberdade-vínculo ${ }^{616}$ da discricionariedade do regulador e o seu dever de buscar a melhor solução juridicamente possível para cada caso concreto examinado. Não é outro, senão esse, o exclusivo propósito de se conferir às autoridades públicas a possibilidade de escolher, dentre as opções que se apresentam, àquela que de maneira ótima solucione o caso concreto.

As escolhas públicas não são seara de foro íntimo do regulador. Muito pelo contrário, são de foro público, razão pela qual o processo formativo das decisões regulatórias discricionárias deve ser externalizado pelo regulador e conhecido por todos os interessados. Ademais, devem ser resultado de exame absolutamente racional e objetivo e em nada aproximar-se de avaliações de cunho pessoal e subjetivo do regulador.

Controlar o universo de ação discricionária do regulador não é tarefa fácil. Os princípios gerais do

direito conferem as diretrizes que devem pautar as decisões regulatórias discricionárias, mas em razão da abstração que lhes é inerente e da subjetividade que

${ }^{616}$ A excelente expressão é de Odete MEDAUAR e ressalta que a discricionariedade da autoridade pública não é livre de peias, ao contrário, é vinculada ao sistema jurídico. O Direito Administrativo em Evolução, p. 194. 
envolve a sua aplicação, não se constituem em parâmetros que possam ter sua observância aferida em concreto nos casos mais difíceis.

Acreditamos que os parâmetros concretos e objetivos apresentados - (i) vinculação aos precedentes da ANATEL; (ii) motivação positiva e negativa de todos os atos do processo decisório; (iii) transparência do processo decisório; e (iv) efetividade e o prognóstico da efetividade das decisões regulatórias discricionárias - permitem a aferição, caso a caso, da correção e da adequação das decisões regulatórias da ANATEL e, bem assim, da adoção ou não da "melhor solução juridicamente possível” pelo regulador.

Estes parâmetros, ademais, pressupostos em um ambiente processualizado de ponderação de interesses legítimos em contraste, se prestariam a possibilitar aos interessados o acompanhamento do processo decisório da ANATEL, nortear o próprio regulador ao longo do processo de escolhas discricionárias e, por fim, auxiliar o Poder Judiciário por ocasião da confrontação das decisões regulatórias discricionárias em juízo. 


\section{CONSIDERAÇÕES FINAIS}

A discricionariedade nos processos decisórios da ANATEL foi estudada na conjuntura do Estado Contemporâneo, marcado especialmente (i) pela implosão da dicotomia público - privado e, por conseguinte, da supremacia, em abstrato, do interesse público sobre o privado; (ii) pela multiplicidade de interesses legítimos conviventes e em conflito que exigem, ao final, a sua mediação ativa pelas autoridades públicas; (iii) pela ampliação dos bordes da legalidade estrita para a juridicidade proporcionando, concomitantemente, maior espaço de atuação discricionária ao agente estatal e mais contornos ao seu agir; e (iv) pela pluralidade de pólos de decisão discricionária, com destaque para às Agências Reguladoras, com autonomia reforçada, tal como a ANATEL.

Esse contexto permitiu-nos verificar a ampla margem de discricionariedade da Administração Pública e, especificamente, do regulador, nos dias atuais.

Em seguida, constatamos que o mau uso da discricionariedade administrativa pode desvirtuá-la em arbitrariedade, isto é, desvincular o agir administrativo da ordem jurídica vigente ou, em outras palavras, desbordá-lo para o desvio de poder da autoridade pública e para a captura do regulador.

Diante, pois, de um cenário de ampla discricionariedade administrativa concluímos existir, igualmente, um amplo espaço para o cometimento de arbitrariedades por parte das autoridades públicas e do regulador e, bem assim, que o administrado e, precisamente o regulado, encontram-se submetidos ao risco de potencial uso arbitrário da discricionariedade administrativa, em especial quando os seus interesses são examinados, em concreto, pelo regulador.

Apresentamos, em sequência, estudo de casos da Agência Nacional de Telecomunicações - ANATEL, relativos à transferência de controle de operadoras de serviços de telecomunicações, no qual evidenciamos concretamente a fragilidade e a hiposuficiência dos regulados em face de decisões discricionárias desparametrizadas da Agência Reguladora e a dificuldade, senão impossibilidade, por ausência de critérios 
objetivos, de seu acompanhamento e controle por parte dos interessados e dos órgãos de fiscalização.

Os estudos e a pesquisa jurídica realizados permitiram, assim, a construção do nosso diagnóstico no sentido de que à ampla discricionariedade do regulador da ANATEL não correspondem instrumentos que permitam o seu controle de maneira concreta e objetiva.

O questionamento principal da dissertação, então, resumiu a problemática decorrente de nosso diagnóstico: Como enfrentar os riscos das escolhas discricionárias regulatórias?

A resposta a esse questionamento começou a ser trilhada com a revisitação de nossas hipóteses de trabalho:

(i) A discricionariedade nos processos decisórios declaratórios das Agências Reguladoras, no âmbito do exercício da mediação ativa de interesses legítimos, não é incondicionada e ilimitada; $e$

(ii) As escolhas administrativas (e regulatórias) devem ser previsíveis e passíveis de amplo e objetivo controle pelos interessados e pelos órgãos de fiscalização, especialmente, pelo Poder Judiciário.

A primeira hipótese formulada restou comprovada, em abstrato, ao longo da dissertação, haja vista que verificamos, em larga medida, que não há agir administrativo legítimo desvinculado da ordem jurídica. Identificamos e colecionamos robusta doutrina nesse sentido.

Ambas as hipóteses foram, assim, testadas no âmbito do controle judicial.

E, ao término de nossos estudos, verificamos que o condicionamento e limitação dos atos regulatórios discricionários à ordem jurídica (hipótese $i$ ) não pode ser comprovada no âmbito do controle judicial, na medida em que identificamos na doutrina administrativista majoritária a defesa por um núcleo intocável dos atos administrativos pelo Poder Judiciário e, bem assim, a sustentação de que as decisões regulatórias discricionárias devem preponderar, em razão da sua tecnicidade, com relação às decisões 
judiciais. A essas constatações somou-se, ainda, a verificação de que o Poder Judiciário ainda encontra-se reticente no que tange ao controle efetivo dos atos regulatórios discricionários. Concluímos, desta feita, que não se pode afirmar genericamente que, em concreto, as decisões regulatórias discricionárias são, efetivamente condicionadas e limitadas à ordem jurídica ou, em outras, palavras, não são arbitrárias.

Constatamos, ainda, que a previsibilidade e o amplo e objetivo controle das escolhas regulatórias pelos regulados e pelo Poder Judiciário (hipótese 2), na mesma medida, não pode ser comprovada, haja vista à inexistência e à insuficiência dos mecanismos objetivos de acompanhamento do processo formativo das decisões discricionárias das Agências Reguladoras e de sua confrontação no âmbito judicial.

Em vista dessas conclusões e com base no estudo de casos realizado, pudemos formular nossa proposta de parâmetros concretos e objetivos que permitiriam, a um só tempo, o acompanhamento, pelos interessados, do processo formativo das decisões regulatórias discricionárias da ANATEL e a sua confrontação, no âmbito judicial, em vista de eventual cometimento de arbitrariedades pelo regulador.

Os parâmetros desenvolvidos foram os seguintes: (i) vinculação aos precedentes da ANATEL; (ii) motivação positiva e negativa de todos os atos do processo decisório; (iii) transparência do processo decisório; e (iv) efetividade e o prognóstico da efetividade das decisões regulatórias discricionárias.

Acreditamos que esses parâmetros, além de permitirem o acompanhamento e confrontação das decisões regulatórias discricionárias, contribuem, ademais, para uma atuação mais coesa e comprometida do regulador setorial.

Estamos cientes de que a flexibilidade, inerente à discricionariedade, pressupõe algum espaço de atuação para o regulador, mas esse é um espaço vinculado à ordem jurídica - e não livre. Não se pretende, nessa medida, com a nossa proposta, engessar a atuação discricionária do regulador, imprescindível, como vimos ao longo da dissertação, à busca e ao atingimento da melhor solução juridicamente possível em cada caso concreto. 
Intentamos, isso sim, colaborar com a redução das decisões regulatórias discricionárias arbitrárias e, assim, fortalecer as Agências Reguladoras. Afinal, não basta amarrar Ulisses no mastro para impedi-lo de sucumbir ao canto das sereias. ${ }^{617}$

617 Cf. Juarez FREITAS. Discricionariedade Administrativa e o Direito Fundamental à Boa Administração Pública, p. 10, 


\section{BIBLIOGRAFIA FINAL}

ADAMI, Mateus Piva. A Discricionariedade Administrativa em Face do Princípio da Eficiência. Dissertação de mestrado defendida na Faculdade de Direito do Largo São Francisco da Universidade de São Paulo em 2007.

AFONSO DA SILVA, Virgílio. A Constitucionalização do Direito. São Paulo: Malheiros, $1^{\mathrm{a}}$ edição, $2^{\mathrm{a}}$ tiragem, 2008.

. O Proporcional e o Razoável. Rio de Janeiro: Revista dos Tribunais, v. 798, 2002.

ALESSI, Renato. Sistema Istituzionale del Diritto Amministrativo Italiano. Milão: Giuffrè, $3^{\mathrm{a}}$ ed., 1960.

. Teoria dos Direitos Fundamentais. Tradução Virgílio Afonso da Silva. Malheiros Editores. 2008.

AMARAL, Antônio Carlos Cintra. O Princípio da Publicidade no Direito Administrativo. Revista Brasileira de Direito Público - RBDP. Belho Horizonte: Fórum, ano 1, n. ${ }^{\circ}$ 2, 2003.

ANTUNES, Luís Filipe Colaço. Mito e realidade da Transparência Administrativa. Boletim da Faculdade de Direito de Coimbra - Estudos em Homenagem ao Prof.. Doutor Afonso Rodrigués Queiró, 1990.

ARAGÃO, Alexandre Santos de. Agências Reguladoras e a Evolução do Direito Administrativo Econômico. Rio de Janeiro: Forense, 2009.

Teoria das Autolimitações Administrativas: Atos Próprios, Confiança legítima e Contradição entre Órgãos administrativos. Revista Eletrônica de Direito Administrativo REDAE. Salvador: Instituto de Direito Público, n. ${ }^{\circ}$ 14, 2008. Disponível em www.direitodoestado.com.br/redae.asp. Acesso em 05/11/2011.

A Concepção Pós-Positivista do Princípio da Legalidade. Revista de Direito Administrativo - RDA. Rio de Janeiro: Fundação Getúlio Vargas, v. 236, 2004.

A "Supremacia do Interesse Público" no Advento do Estado de Direito e na Hermenêutica do Direito Público Contemporâneo. In: Interesses Públicos versus Interesses 
Privados: Desconstruindo o Princípio de Supremacia do Interesse Público. Rio de Janeiro: Lumem Juris, 2010.

As Agências Reguladoras Independentes e a Separação de Poderes: Uma Contribuição da Teoria dos Ordenamentos Setoriais. São Paulo: Revista dos Tribunais, v. 90, n. ${ }^{\circ} 786,2001$.

. O Princípio da Eficiência. Revista Brasileira de Direito Público - RBDP. Belo Horizonte: Fórum, ano 2, n. ${ }^{\circ}$ 4, 2004.

Atividades Privadas Regulamentadas: Autorização Administrativa, Poder de Polícia e Regulação. Revista de Direito Público da Economia - RDPE. Belo Horizonte: Fórum, ano 3, n. ${ }^{\mathrm{o}}$ 10, 2005.

ATIENZA, Manuel. Sobre lo Razonable en el Derecho. Revista Española de Derecho Constitucional, ano 9, n. ${ }^{\circ} 27,1989$.

ÁVILA, Humberto Bergmann. Teoria dos Princípios. São Paulo: Malheiros, 2008. . Repensando o Princípio da Supremacia do Interesse Público sobre o Particular. In: O Direito Público em Tempos de Crise - Estudos em Homenagem a Ruy Rubem Ruschel. Porto Alegre: Saraiva. 1999.

Razoabilidade: Definição e Aplicação. In: Direito Administrativo. Estudos em Homenagem à Diogo de Figueiredo Moreira Neto. ÓSORIO, Fábio Medina e SOUTO, Marcos Juruena Villela (coords.). Rio de Janeiro: Lumen Juris, 2006.

A Distinção entre Princípios e Regras e a Redefinição do Dever de Proporcionalidade. Revista de Direito Administrativo - RDA. Rio de Janeiro: Renovar, v. $215,1999$.

Sistema Constitucional Tributário. São Paulo: Saraiva, 2004.

Moralidade, Razoabilidade e Eficiência na Atividade Administrativa. Revista Eletrônica de Direito do Estado, n. ${ }^{\circ}$ 4, 2005. Disponível em www.direitodoestado.com.br./rede.asp. Acesso em 05/11/2011 
BACIGALUPO, Mariano. La Discrecionalidad Administrativa: Estructura, Control Judicial y Limites Constitucionales de su Atribución. Madri: Marcial Pons, 1997.

BAGATIN. Andreia Cristina. O Problema da Captura das Agências Reguladoras Independentes. Dissertação de Mestrado apresentada à Faculdade de Direito do Largo São Francisco em 2010.

BANDEIRA DE MELO, Celso Antônio. Curso de Direito Administrativo. São Paulo: Malheiros, $26^{\mathrm{a}}$ ed., 2008.

. Grandes Temas de Direito Administrativo. São Paulo: Malheiros, 2009.

. Discricionariedade e Controle Jurisdicional. São Paulo: Malheiros, $2^{\mathrm{a}}$ ed., 2007.

. Legalidade, Motivo e Motivação do Ato Administrativo. Revista de Direito Público - RDP. São Paulo: Maleiros, v. 90, 1989.

. Legalidade - Discricionariedade - Seus Limites e Controle, in Revista de Direito Público. V 86, abril a junho de 1988, ano XXI. Editora Revista dos Tribunais.

. O Conteúdo Jurídico do Princípio da Igualdade. São Paulo: Malheiros, 1978.

Anulação de Ato Administrativo. Devido Processo Legal e Motivação. Revista Trimestral de Direito Público - RTDP. São Paulo: Malheiros, v. 45, 2004.

BANDEIRA DE MELLO, Oswaldo Aranha. Princípios Gerais de Direito Administrativo. São Paulo: Malheiros, $3^{\text {a }}$ ed., v. I, 2007.

BARROSO, Luís Roberto (Org.). A Nova Interpretação Constitucional. Ponderação, Direitos Fundamentais e Relações Privadas. Rio de Janeiro: Renovar, $3^{\text {a }}$ ed., 2008.

A Segurança Jurídica na Era da Velocidade e do Pragmatismo. Revista Trimestral de Direito Público - RTDP. São Paulo: Malheiros, v. 43, 2003.

Neoconstitucionalismo e Constitucionalização do Direito (O triunfo tardio do direito constitucional no Brasil). Revista Trimestral de Direito Público - RTDP. São Paulo: Malheiros, n. ${ }^{\circ}$ 44, 2003.

BASTOS. Celso Ribeiro. O Princípio da Moralidade no Direito Público. Cadernos de Direito Constitucional e Ciência Política. São Paulo: Revista dos Tribunais, ano 6, n. ${ }^{\circ}$ 22, 1998. 
BIELSA, Rafael. Principios de Derecho Administrativo. Buenos Aires: El Ateneo, $2^{\mathrm{a}}$ ed., 1948.

BINENBOJM, Gustavo. A Nova Jurisdição Constitucional Brasileira: Legitimidade Democrática e Instrumentos de Realização. Rio de Janeiro: Renovar, $2^{a}$ Edição, 2004.

. Uma Teoria do Direito Administrativo: Direitos Fundamentais, Democracia e Constitucionalização. Rio de Janeiro; Renovar, $2^{\mathrm{a}}$ ed., 2008.

O Sentido da Vinculação Administrativa à Juridicidade no Direito Brasileiro. MARQUES NETO, Floriano de Azevedo; ARAGÃO, Alexandre Santos de. (Coords.) Direito Administrativo e seus Novos Paradigmas. Belo Horizonte: Fórum, 2008.

A Constitucionalização do Direito Administrativo no Brasil: um inventário de avanços e retrocessos. Revista Brasileira de Direito Público - RBDP. Belo Horizonte: Fórum, ano.4, n. ${ }^{\circ}$ 14, 2006.

Da Supremacia do Interesse Público ao Dever de Proporcionalidade: Um Novo Paradigma para o Direito Administrativo. In: Interesses Públicos versus Interesses Privados: Desconstruindo o Princípio de Supremacia do Interesse Público. Rio de Janeiro: Lumem Juris, 2010.

BOBBIO, Norberto. Estado, Governo e Sociedade. Rio de Janeiro: Paz e Terra, $3^{\mathrm{a}}$ Ed. 1990.

- O Futuro da Democracia: Uma Defesa das Regras do Jogo. Rio de Janeiro: Editora Paz e Terra, 1986.

. Liberalismo e Democracia. Trad. Brasileira de Marco Aurélio Nogueira. São Paulo: Brasiliense, $2^{\mathrm{a}}$ ed., 1988.

BORGES, Alice Maria Gonzalez. Supremacia do Interesse Público: Desconstrução ou Reconstrução? Boletim de Direito Administrativo - BDA, São Paulo, ano. XXIII, n. 7, 2007.

Interesse público: Um Conceito a Determinar. In: Temas de Direito Administrativo Atual (Estudos e Pareceres). Belo Horizonte: Fórum, 2004. 
BRANDÃO. Antônio José. Moralidade Administrativa. Revista de Direito Administrativo - RDA. Rio de Janeiro: Renovar, n. ${ }^{\circ}$ 25, 1951.

CAETANO, Marcello. Manual de direito administrativo. Coimbra: Almedina, 1983.

CAMPILONGO. Celso Fernandes. Direito e Democracia: Max Limonad, 2a ed., 2000.

O Direito na Sociedade Complexa. São Paulo: Max Limonad, 2000.

; ARAGAO, A.; BADIN, A. ; BINENBOJM, G. ; SALGADO, L. H. . A representação judicial das agências e seus limites. In: Lucia Helena Salgado. (Org.). Marcos Regulatórios no Brasil. Judicialização e independência. Rio de Janeiro: IPEA, 2009.

. Direitos Fundamentais e Poder Judiciário. In: Fundação Konrad Adenauer. (Org.). Debates - A Constituição Democrática Brasileira e o Poder Judiciário. Porto Alegre: Centro de Estudos Konrad Adenauer, 1999.

CAMPOMAR, Marcos Cortez. Do uso de 'estudo de caso' em pesquisas para dissertações e teses em administração. Revista de Administração. São Paulo, v. 26, n. ${ }^{3}$ 3, 1991.

CANOTILHO, José Joaquim Gomes. Direito Constitucional. Coimbra: Almedina, 1995.

Direito Constitucional e Teoria da Constituição. Coimbra: Almedina, $7^{\mathrm{a}}$ ed., 2003.

CAPPLLETTI, Mauro. O Controle Judicial de Constitucionalidade das Leis no Direito Comparado. Porto Alegre: Sérgio Antônio Fabris, 1984.

CASSAGNE, Juan Carlos. Derecho Administrativo. Buenos Aires: Lexis Nexis, $8^{\text {a }}$ ed., 2006.

La Revisión de la Discrecionalidad Administrativa por el Poder Judicial. In: Estudios de Derecho Público. Buenos Aires: De Palma,1995.

CASSESSE, Sabino. Corso di Diritto Amministrativo. 2a . Ed., Milão: A. Giuffrè, 2006.

Las Bases del Derecho Administrativo. Madri: Instituto Nacional de Administración Pública, 1994. 
Lo 'Stato Pluriclasse' in Massimo Severo Giannini. In: L'Unità del Diritto Massimo Severo Giannini e la Teoria Giuridica. Bolonha: Il Mulino. 1994.

CASTRO, Rodrigo Pironti Aguirre de. Processo Administrativo e Controle da Atividade Regulatória. Belo Horizonte: Fórum, 2005.

CAVALCANTI, Themístocles Brandrão. Do Poder Discricionário. Revista de Direito Administrativo- RDA. Seleção Histórica. Rio de Janeiro: Renovar, 1991.

CHEVALIER, Jacques. O Estado Pós-Moderno. Tradução Marçal JUSTEN FILHO. Belo Horizonte: Fórum, 2009.

CINTRA, Antonio Carlos de Araújo. Motivo e Motivação do Ato Administrativo. São Paulo: Revista dos Tribunais, 1979.

CIRNE LIMA, Ruy. Princípios de Direito Administrativo. São Paulo: Malheiros Editores, $7^{\mathrm{a}}$ edição, 2007.

COLE, Charles D. Precedente Judicial - A Experiência Americana. Revista de Processo. Instituto Brasileiro de Direito Processual. Rio de Janeiro: Revista dos Tribunais, n. ${ }^{\circ}$ 92, 1998.

COSCIONE, Milene Louise Renée. Telecomunicações. Doutrina, Jurisprudência, Legislação e Regulação Setorial. São Paulo: Saraiva, 2011.

COSTA, Regina Helena. Conceitos Jurídicos Indeterminados e Discricionariedade Administrativa. Revista da Procuradoria Geral do Estado de São Paulo. São Paulo, v 29, 1988.

COUTO E SILVA, Almiro R. "Princípio da Legalidade da Administração Pública e da Segurança Jurídica do estado de direito Contemporâneo". In: Revista de Direito Público. São Paulo: Editora Revista dos Tribunais, n. ${ }^{\circ} 84,1987$.

CRETELLA JUNIOR, José. Ato Administrativo - A Tridimensão da Discricionariedade, in Revista de Direito Administrativo - RDA. Rio de Janeiro: Renovar, v. 119, 1975.

. O Desvio de Poder na Administração Pública. Rio de Janeiro: Forense, 1997.

. O Mérito do Ato Administrativo. Revista de Direito Administrativo - RDA. Rio de Janeiro: Fundação Getúlio Vargas, v. 79, 1965. 
Curso de Direito Administrativo. São Paulo: Revista dos Tribunais, 2a ed., 1991, CUOCULO, Fausto. Istituzioni di Diritto Publlico. Milão: Giufrè, 10ª edição, 1998.

CYRINO, André Rodrigues. Separação de Poderes, Regulação e Controle Judicial: Por um Amicus Curiae Regulatório. Revista Brasileira de Direito Público - RBDP. Belo Horizonte: Fórum, ano 5, n. ${ }^{\circ}$ 19, 2007.

DAL BOSCO, Maria Goretti. Discricionariedade em Políticas Públicas. Curitiba: Juruá, 2008 .

DALLARI, Adilson Abreu. Formalismo e Abuso de Poder. Revista Trimestral de Direito Público - RTDP. São Paulo: Maleiros, v. 48, 2004.

Controle do Desvio de Poder. Revista Trimestral de Direito Público - RTDP. São Paulo: Malheiros, v. 46, 2004.

DAROCA, Eva Desdentado. Los Problemas del Control Judicial de la Discrecionaldad Técnica. Madri: Civitas, 1997.

DIAZ, José Ortiz. El Precedente Administrativo. In: Revista de Administración Pública, v. $24,2000$.

DI PIETRO, Maria Sylvia Zanella. Direito Administrativo. São Paulo: Atlas, $21^{\mathrm{a}}$ ed., 2008. Discricionariedade Administrativa na Constituição de 1988. São Paulo: Atlas, $2^{\mathrm{a}}$ ed., 2007.

O Direito Administrativo Brasileiro sob Influência dos Sistemas de Base Romanística e da Common Law. Revista Eletrônica de Direito Administrativo Econômico. Instituto Brasileiro de Direito Público, n. ${ }^{\circ}$ 8, 2006. Acessível em $<$ www.direitodoestado.com.br/redae.asp>, acesso em 10 de março de 2010.

Discricionariedade Técnica e Discricionariedade Administrativa. Revista Brasileira de Direito Público - RBDP. Belo Horizonte: Fórum, ano 5, n. ${ }^{\circ}$ 17. 2007.

- Parcerias na Administração Pública. Concessão, Permissão, Franquia, Terceirização, Parceria Público-Privada e outras formas. São Paulo: Atlas, $7^{a}$ edição, 2009. 
Limites da Função Reguladora das Agências diante do Princípio da Legalidade. Maria Sylvia Zanella DI PIETRO (Org.). Direito Regulatório: Temas Polêmicos. Belo Horizonte: Fórum, 2009.

Existe um novo direito administrativo?. In: Maria Sylvia Zanella Di Pietro; Carlos Vinícius Alves Ribeiro. (Org.). Supremacia do interesse público e outros temas relevantes do direito administrativo. São Paulo: Atlas, 2010.

O Princípio da Supremacia do Interesse Público: Sobrevivência diante dos Ideais do Neoliberalismo. In: Maria Sylvia Zanella Di Pietro; Carlos Vinícius Alves Ribeiro. (Org.). Supremacia do Interesse Público e outros Temas Relevantes do Direito Administrativo. São Paulo: Atlas, 2010.

Da constitucionalização do direito administrativo: reflexos sobre o princípio da legalidade e a discricionariedade administrativa.. In: Maria Sylvia Zanella Di Pietro; Carlos Vinícius Alves Ribeiro. (Org.). Supremacia do interesse público e outros temas relevantes do direito administrativo. São Paulo: Atlas, 2010.

Alcance do Princípio da Publicidade das Funções Públicas: Transparência e Sigilo. In: Os 20 anos da Constituição da República Federativa do Brasil. Alexandre de Moraes. (Org.). São Paulo: Atlas, 2009.

. Omissões na Atividade Regulatória do Estado e Responsabilidade Civil das Agências Reguladoras. In: Responsabilidade Civil do Estado. FREITAS, Juarez. (Org.). São Paulo: Malheiros, 2006.

Inovações no Direito Administrativo Brasileiro. Revista Interesse Público. Porto Alegre: Notadez, ano VI, n. ${ }^{\circ}$ 30, 2005.

DROMI, Roberto. El Procedimiento Administrativo. Buenos Aires: Ediciones Ciudad Argentina, 1996.

DUARTE, David. Procedimentalização, Participação e Fundamentação: Para uma Concretização do Princípio da Imparcialidade Administrativa como Parâmetro Decisório. Coimbra: Almedina, 1996.

DUNN. Donald J. e Roy M. MERSKY. Legal Research Illustrated. An Abridgment of Fundamentals of Legal Research. Nova York: Fundation Press. 8 edição, 2002. 
ENGISCH, Karl. Introdução ao Pensamento Jurídico. Trad. J. Baptista Machado. Lisboa: Fundação Calouste Gulbenkian, 2001.

ENTERRÍA, Eduardo García de. E TOMÁS-RAMÓN FERNANDEZ. Curso de Direito Administrativo. São Paulo: Revista dos Tribunais, 1991.

—. Legislación Delegada, Potestad Reglamentaria y Control Judicial. Madri: Tecnos, 1970 .

Es Inconveniente o Inutil la Proclamación de la Interdicción de la Arbitrariedad como Principio Constitucional? Uma nota. Revista de Administración Pública, n. ${ }^{\circ}$ 14, 1991.

. Democracia, Jueces y Control de La Administracion. Madri: Civitas, $5^{\text {a }}$ ed., 2000.

ESCOLA, Hector Jorge. Compendio de Derecho Administrativo. Buenos Aires: Depalma, 1979.

FAGUNDES, Miguel Seabra. O Controle dos Atos Administrativo pelo Poder Judiciário. Atualização Gustavo Binenbojm. Rio de Janeiro: Forense, $7^{\mathrm{a}}$ ed., 2005.

. Conceito de Mérito no Direito Administrativo. Revista de Direito Administrativo RDA. Rio de Janeiro: Fundação Getúlio Vargas, seleção histórica, 1945.

FARNSWORTH, E.Allan. An Introduction to the Legal System of the United States. Nova York: Oceana Publications, Inc., $3^{\text {a }}$ edição, 1996.

FERNANDEZ, Tomás-Rámón. Arbitrariedad y Discrecionalidad. Madri: Civitas, 1991. . De la Arbitrariedad de la Administración. Madri: Civitas, 4ª edição, 2002. . Viejas y Nuevas Ideas sobre el Poder Discrecional de la Administración y el Control Jurisdicional de su Ejercici”. Interesse Público. Revista Bimestral de Direito Público, ano 8, n. ${ }^{\circ}$ 37, 2006.

Debe la Administración actuar racional y razonablemente?. Revista Española de Derecho Administrativo - REDA. Madri: Civitas, v. 83, versão CD-ROM.

FIGUEIREDO, Lúcia Valle. Curso de Direito Administrativo. São Paulo: Malheiros, 1994. 
. Controle da Administração Pública. São Paulo: Revista dos Tribunais. 1991.

O Controle Judicial dos Atos Administrativos e a Súmula Vinculante. Revista Brasileira de Direito Público - RBDP. Belo Horizonte:Fórum, ano 2, n. o 4, 2004.

FINE, Toni M. O Uso do Precedente e o Papel do Princípio do Stare Decisis no Sistema Legal Norte-Americano. Rio de Janeiro: Revista dos Tribunais, v. 782, 2000.

FIORINI, Bartolome A. La Discrecionalidad en la Administración Pública. Buenos Aires:Alfa, 1952.

FRAGA, Gabino. Derecho Administrativo. México: Parrua S.A., 1948.

FRANÇA, Phillip Gil. O Controle da Administração Pública: Tutela Jurisdicional, Regulação Econômica e Desenvolvimento. São Paulo: Revista dos Tribunais, 2008.

FRANÇA, Vladimir da Rocha. Considerações sobre o Dever de Motivação dos Atos Administrativos Ampliativos. Revista Trimestral de Direito Público - RTDP. São Paulo: Malheiros, v. 46, 2004.

FRANCO SOBRINHO, Manuel de Oliveira. Moralidade Administrativa e Desvio de Poder. In: O Princípio Constitucional da Moralidade Administrativa. Curitiba: Genesis, 1993.

FREITAS, Juarez. O Controle dos Atos Administrativos e os Princípios Fundamentais. São Paulo: Malheiros, $4^{\mathrm{a}}$ ed., 2009.

Discricionariedade Administrativa e o Direito Fundamental à Boa Administração Pública. São Paulo: Malheiros, $2^{\mathrm{a}}$ ed., 2009.

FROTA, Hidemberg Alves da. O Princípio da Supremacia do Interesse Público sobre o Privado no Direito Positivo Comparado: Expressão do Interesse Geral da Sociedade e da Soberania Popular. Revista de Direito Administrativo - RDA. Rio de Janeiro: Renovar, v. $239,2005$.

GASPARINI, Diógenes. O Desvio de Poder ou de Finalidade em matéria Administrativa. Boletim de Direito Administrativo. Edição Especial, 2008. . Direito Administrativo. São Paulo: Saraiva, 4ª ed., 1995. 
GIACOMUZZI, José Guilherme. A Moralidade Administrativa e a Boa-Fé da Administração Pública: O Conteúdo Dogmático da Moralidade Administrativa. São Paulo: Malheiros. 2002.

A Moralidade Administrativa - História de um Conceito. Revista de Direito Administrativo - RDA. Rio de Janeiro: Renovar, v. 230, 2002.

GIANNINI, Massimo Severo. II Potere Discrezionale della Pubblica Amministrazione. Milão: Giuffrè. 1939.

Diritto Amministrativo. Milão: Giuffrè, 1988.

GRECO. Marco Aurélio. Dinâmica da Tributação e Procedimento. São Paulo: Revista dos Tribunais. 1979.

GORDILLO, Augustín. Tratado de Derecho Administrativo. Buenos Aires: Fundacion de Derecho Administrativo, 2003.

La Administración Paralela. Buenos Aires. Civitas, 1982.

GRAU, Eros Roberto. Direito, Conceitos e Normas Jurídicas. São Paulo: Revistas dos Tribunais, 1988.

. A Ordem Econômica na Constituição de 1988. São Paulo: Malheiros, 7ª ed. 2002.

Discricionariedade técnica e parecer técnico. Revista de Direito Público - RDP, São Paulo, ano 23, n. ${ }^{\circ}$ 93, 1990.

. O Direito Posto e o Direito Pressuposto. São Paulo, Malheiros, $4^{\mathrm{a}}$ ed. 2002.

GUIMARÃES, Letícia. Repensando o Conceito de Função Administrativa: O Dever e a natureza Infralegal em Destaque. Revista Trimestral de Direito Público - RTDP. São Paulo: Malheiros, v. 45, 2004.

GUERRA, Sérgio. Discricionariedade e Reflexividade: Uma Nova Teoria das Escolhas Administrativas. Belo Horizonte: Fórum, 2008.

. Controle Judicial dos Atos Regulatórios. Rio de Janeiro: Lumen Juris, 2005. Introdução ao Direito das Agências Reguladoras. Rio de Janeiro: Freitas Bastos, 2004. 
Discricionariedade na Regulação por Entidades Estatais Independentes. Revista de Direito Público da Economia - RDPE. Fórum: Belo Horizonte, v. 6. 2004.

O Princípio da Proporcionalidade na Pós-Modernidade. Revista Brasileira de Direito Público - RBDP. Belo Horizonte: Fórum, ano 1, n. 3, 2003.

. Teoria da Captura de Agência Reguladora em Sede Pretoriana. Revista de Direito Administrativo - RDA. Rio de Janeiro: Renovar, v. 244. 2006.

Atualidades sobre o Controle Judicial dos Atos Regulatórios. Revista Eletrônica de Direito Administrativo Econômico - REDAE, n. ${ }^{\circ}$ 21, 2010. Acessível em www.direitodoestado.com.br/revista/REDAE-21-FEVEREIRO-SERGIO-GUERRA.pdf. Acesso em 05/11/2011.

JUSTEN FILHO, Marçal. Curso de Direito Administrativo. São Paulo: Saraiva, 4 ${ }^{\mathrm{a}}$ ed., 2009.

O Direito das Agências Reguladoras Independentes. São Paulo: Dialética, 2002.

Direito Administrativo de Espetáculo. MARQUES NETO, Floriano de Azevedo; ARAGÃO, Alexandre Santos de. (Coords.) Direito Administrativo e seus Novos Paradigmas. Belo Horizonte: Fórum, 2008.

Marçal JUSTEN FILHO. Ampla Defesa e Conhecimento de Argüições de Inconstitucionalidade e Legalidade no Processo Administrativo. Revista Dialética de Direito Tributário, v. 25, 1998.

LEAL, Victor Nunes. Problemas de Direito Público. Brasília: Nova Fronteira, v. I, 1997.

- Reconsideração do Tema do Abuso de Poder. In: Revista de Direito Administrativo. Seleção Histórica-FGV. Rio de Janeiro: Renovar, 1991.

- Poder Discricionário e Ação Arbitrária da Administração. Revista de Direito Administrativo - RDA. Rio de Janeiro: Renovar, v. 14. 1948.

LIMA, Augusto César Moreira. Precedentes no Direito. São Paulo: LTr, 2001.

LINARES, Juan Francisco. Poder Discrecional Administrativo. Buenos Aires: El Ateneo, 1958. 
LOPES, José Reinaldo de Lima. Raciocínio Jurídico e Economia. Revista de Direito Público da Economia - RDPE. Belo Horizonte: Fórum, ano 2, n. ${ }^{\circ}$ 8, 2004.

MACHADO, Santiago Muñoz. Servicio público y mercado. Madrid. Civitas, 1998.

MAGIDE, Mariano. Limites Constitucionales de las Administraciones Independientes. Madri: INAP, 2000.

MARIN, Carmem Chinchilla. La Desviación de Poder. Madri: Editorial Civitas S.A., 1989.

MARINONI, Luiz Guilherme. Precedentes Obrigatórios. São Paulo: Revista dos Tribunais, 2010.

MARQUES NETO, Floriano de Azevedo. Regulação Estatal e Interesses Públicos, Ed. Malheiros, 2002.

Agências Reguladoras Independentes. Fundamentos e seu Regime Jurídico. Belo Horizonte: Fórum, 2005.

Pensando o Controle da Atividade de Regulação Estatal. In: Temas de Direito Regulatório. GUERRA, Sérgio (coord.). Rio de Janeiro: Freitas Bastos, 2004.

- Discricionariedade Administrativa e Controle Judicial da Administração. In:

Processo Civil e Interesse Público. SALLES, Carlos Alberto de (Org.). São Paulo: Revista dos Tribunais, 2003.

- Discricionariedade e Regulação Setorial - O Caso do Controle dos Atos de Concentração por Regulador Setorial. ARAGÃO, Alexandre Santos (Coord.). O Poder Normativo das Agências Reguladoras. Rio de Janeiro: Forense, 2008.

. Princípios da Proporcionalidade e da Legalidade na Regulação Estatal. Revista de Direito Administrativo - RDA. Rio de Janeiro: Renovar, v. 232, 2003.

Limites à Abrangência e à Intensidade da Regulação Estatal. Revista de Direito Público da Economia - RDPE. Belo Horizonte: Fórum, ano 1, n. ${ }^{\circ}$ 1, 2003.

A Nova Regulação dos Serviços Públicos. Revista de Direito Administrativo RDA. Rio de Janeiro: Renovar, v. 228, 2002. 
A Nova Regulação Estatal e as Agências Independentes. In: Direito Administrativo Econômico. SUNDFELD, Carlos Ari (coord.) São Paulo: Malheiros. 2006. . Direito das Telecomunicações e ANATEL. In: Direito Administrativo Econômico. SUNDFELD, Carlos Ari (coord.) São Paulo: Malheiros. 2006.

. Ensaio sobre o Processo como Disciplina do Exercício da Atividade Estatal. In: Teoria do Processo: Panorama Doutrinário Mundial. DIDIER JR., Fredie e JORDÃO, Eduardo Ferreira. Salvador: Podivm, 2009.

. Princípios do Processo Administrativo. Fórum Administrativo. Belo Horizonte: Fórum, ano 4, n. ${ }^{\mathrm{o}}$ 37, 2004.

A primeira década da Resolução n. ${ }^{o}$ 101/1999 da Anatel: a década da provação do regulamento de controle. Revista de Direito de Informática e Telecomunicações - RDIT. Belo Horizonte: Fórum, ano 4. n. ${ }^{\circ}$ 7, 2009.

MARTIN, Carlos de Cabo. Sobre el Concepto de Ley. Madri: Editorial Trotta, 2000.

MATTOS, Paulo Todescan Lessa. Autonomia Decisória, Discricionariedade Administrativa e Legitimidade da Função Reguladora do Estado no Debate Jurídico Brasileiro. In: O Poder Normativo das Agencias Reguladoras. ARAGÃO, Alexandre Santos de (coord.). Rio de Janeiro: Forense: 2006.

Regulação Econômica e Democracia - O Debate Norte-Americano, São Paulo: 34. 2004.

. Regulação Econômica e Democracia - O Debate Europeu. São Paulo: Singular, 2006.

O Novo Estado Regulador no Brasil. Eficiência e Legitimidade. São Paulo: Singular. 2006.

MEDAUAR, Odete. Direito Administrativo Moderno. São Paulo: Revista dos Tribunais, $12^{\mathrm{a}}$ ed., 2008.

O Direito Administrativo em Evolução. São Paulo: Revista dos Tribunais, $2^{a}$ ed., 2003. 
Desvio de Poder. Revista de Direito Administrativo - RDA. Rio de Janeiro: Renovar, v. 228, 2002.

(coord.). Processo administrativo - Aspectos atuais. São Paulo: Cultural Paulista, 1998.

MEIRELLES, Hely Lopes. Direito Administrativo Brasileiro. São Paulo: Malheiros, 26 a ed., 2001.

Os Poderes do Administrador Público. Revista de Direito Administrativo - RDA. Seleção História. Rio de Janeiro: Renovar, 1991.

. A Administração Pública e seus Controles. Revista de Direito Público - RDP. São Paulo: Revista dos Tribunais, n. ${ }^{\circ} 23,1973$.

MELLO, Rafael Munhoz de. Processo Administrativo, Devido Processo Legal e a Lei 9.784/1999. Revista Trimestral de Direito Público, São Paulo, n. ${ }^{\circ}$ 38, 2002.

O Desvio de Poder. Revista de Direito Administrativo - RDA. Rio de Janeiro: Renovar, v. 228, 2002.

MENDONÇA, José Vicente Santos de Mendonça. A Captura Democrática da Constituição Econômica: uma proposta de releitura das atividades públicas de fomento, disciplina e intervenção direta na economia à luz do pragmatismo e da razão pública. Tese de Doutorado. Universidade do Estado do Rio de Janeiro. 2010.

MERKL, Adolfo. Teoria General de Derecho Administrativo. Granada: Comares, 2004.

MESSITE, Peter J. O Papel do Precedente no Direito Norte-Americano. Revista do Instituto de Ciências Jurídicas e Sociais do Centro Universitário de Brasília. Brasília: Universitas/JUS, n. ${ }^{\circ}$ 6, 2002.

MIGUEL, Luis García San (editor). El Principio de Igualdad. Madri: Dykinson, 2000.

MIRANDA, Tássia Baia. Stare Decisis e a Aplicação do Precedente no Sistema NorteAmericano. Revista da Ajuris. Rio Grande do Sul: Ajuris, n. ${ }^{\circ}$ 106, 2007.

MIRAGAYA, Rodrigo Bracet. A Proteção da Confiança Legítima como Princípio Fundamental no Direito Administrativo. Dissertação de Mestrado. Faculdade de Direito do largo São Francisco. Universidade de São Paulo, 2011. 
MODESTO, Paulo. Autovinculação da Administração Pública. Revista Brasileira de Direito Público - RBDP. Belo Horizonte: Fórum, ano 8, n. ${ }^{\circ}$ 29, 2010.

. Notas para um Debate sobre o Princípio Constitucional da Eficiência. Revista Eletrônica de Direito Administrativo Econômico - REDAE. Instituto Brasileiro de Direito público, n. ${ }^{\circ}$ 10, 2007. Acessível em www.direitodoestado.com.br/redae.asp. Acesso em $05 / 11 / 2011$.

MORAES. Alexandre de. Princípio da Eficiência e Controle Jurisdicional dos Atos Administrativos Discricionários. Revista de Direito Administrativo - RDA. Rio de Janeiro: Renovar, v. 243, 2006.

MORAES, Germana. Controle Jurisdicional da Administração Pública. São Paulo: Editora Dialética, 1999.

MOREIRA, Egon Bockman. Processo Administrativo. Princípios Constitucionais e a Lei 9.784/99. São Paulo: Malheiros, $4^{\mathrm{a}}$ edição, 2010.

. O Processo Administrativo no Rol dos Direitos e Garantias Individuais. Revista Trimestral de Direito Público - RTDP. São Paulo: Malheiros, v. 43, 2003.

- Processo Administrativo e Princípio da Eficiência. In: As Leis de Processo Administrativo. SUNDFELD, Carlos Ari e MUNÕZ, Guillermo Andrés (coords.). São Paulo: Malheiros, 2000.

\footnotetext{
—. Agências Reguladoras Independentes, Poder Econômico e Sanções Administrativas. In: Temas de Direito Regulatório. GUERRA, Sérgio (coord.). Rio de Janeiro: Freitas Bastos, 2004.
}

MOREIRA NETO. Diogo de Figueiredo. Curso de Direito Administrativo. Rio de Janeiro: Forense, $12^{\mathrm{a}}$ ed., 2001.

- Novos Institutos Consensuais da Ação Administrativa. Revista de Direito Administrativo - RDA. Rio de Janeiro: Renovar, v. 231, 2003.

. Direito Regulatório. Rio de Janeiro: Renovar, 2003.

. Mutações do Direito Público. Rio de Janeiro: Renovar, 2006.

. Mutações do Direito Administrativo. Rio de Janeiro: Renovar, $3^{\mathrm{a}}$ ed., 2007. 
Novas Tendências da Democracia: Consenso e Direito Público na Virada do Século - O Caso Brasileiro. Revista Brasileira de Direito Público - RBDP. Belo Horizonte: Fórum, ano. 1, n. ${ }^{\circ}$ 3, 2003.

O Novo Papel do Estado na Economia. Revista de Direito Público da Economia RDPE. Belo Horizonte: Fórum, ano. 3, n. ${ }^{\circ}$ 11, 2005.

Direito Regulatório: A Alternativa Participativa e Flexível para a Administração Pública de Relações Setoriais Complexas no Estado Democrático. Rio de Janeiro: Renovar, 2003.

Quatro Paradigmas do Direito administrativo Pós-Moderno: legitimidade, finalidade, eficiência, resultados. Belo Horizonte: Fórum, 2008.

Legitimidade e Discricionariedade: Novas Reflexões sobre os Limites e Controle da Discricionariedade. Rio de Janeiro: Forense, $1^{\text {a }}$ edição, 1989.

A Regulação sob a Perspectiva da Nova Hermenêutica. Revista Eletrônica de Direito Administrativo Econômico - REDAE. Salvador: Instituto Brasileiro de Direito Público, n. ${ }^{\circ}$ 12, 2008. Disponível em www.direitodoestado.com.br/redae.asp. Acesso em 07/07/2010.

MOREIRA, Vital. Auto-Regulação Profissional e Administração Pública. Coimbra: Almedina, 1997.

. MAÇAS, Fernanda e. Autoridades Reguladoras Independentes. Estudo e Projecto de Lei-Quadro. Coimbra: Coimbra Editora. 2003.

MÓRON, Miguel Sanchez. Discrecionalidad Administrativa y Control Judicial. Madri: Tecnos, 1994.

NOHARA, Irene Patrícia. Limites à Razoabilidade nos Atos Administrativos. São Paulo: Altas, 2006.

OLIVEIRA, Gustavo Henrique Justino. Participação Administrativa. In: Direito Administrativo. Estudos em Homenagem à Diogo de Figueiredo Moreira Neto. ÓSORIO, Fábio Medina e SOUTO, Marcos Juruena Villela (coords.). Rio de Janeiro: Lumen Juris, 2006. 
- Governança Pública e Parcerias do Estado: A Relevância dos Acordos Adminstrativos para a Nova Gestão Pública. Revista Brasileira de Direito Público - RBDP. Belo Horizonte: Fórum, ano 6, n. ${ }^{\mathrm{o}} 23,2008$.

OLIVEIRA, José Roberto Pimenta. Os Princípios da Razoabilidade e da Proporcionalidade no Direito Administrativo Brasileiro. Malheiros Editores: 2006.

OLIVEIRA, Rafael Carvalho Rezende. A Constitucionalização do Direito Administrativo. Rio de Janeiro: Lumen Juris, 2009.

OLIVEIRA, Regis Fernandes de. O Conflito entre o Público e o Privado no Direito. Revista Trimestral de Direito Público - RTDP. São Paulo: Malheiros, n. o 39, 2002.

ORTIZ, Gaspar Ariño. Principios de Derecho Público Económico. Granada: Comares, $3^{\mathrm{a}}$ ed., 2004.

. El Control Judicial de las Entidades Reguladoras. La Necessária Expansión el Estado de Derecho. (mimeo)

La Regulación Econômica - Teoria y Prática de la Regulación para la Competencia. Buenos Aires: Depalma. 1996.

. Derechos del Rey, Derechos del Pueblo. Actas de Historia de la Administración. Madrid: ENAP, 1971

OSÓRIO, Fabio Medina. Direito Administrativo Sancionador. São Paulo: Revista dos Tribunais, 2000.

— Existe uma Supremacia do Interesse Público sobre o Privado no Direito Administrativo? Revista de Direito Administrativo - RDA. Rio de Janeiro: Renovar, v. $220,2000$.

OTERO, Paulo. Legalidade e Administração Pública: O Sentido da Vinculação Administrativa à Juridicidade. Coimbra: Almedina, 2003.

PALMA, Juliana Bonacorsi de, WANG, Daniel Wei Liang e COLOMBO, Daniel Gama. Revisão Judicial dos Atos das Agências Reguladoras: Uma Análise da Jurisprudência Brasileira. Controle Judicial dos Atos Regulatórios: uma análise da jurisprudência. In: 
Mario Gomes Schapiro. (Org.). Direito Econômico Regulatório. São Paulo: Saraiva, 2010, v. 2 .

- Atuação Administrativa Consensual: Estudo dos Acordos Substitutivos no Processo Administrativo Sancionador. Dissertação de Mestrado apresentada à Faculdade de Direito do Largo São Francisco da Universidade de São Paulo, 2010

PASTOR, Juan Alfonso Santamaría. Estado Social de Derecho y Control Jurídico de Eficacia de la Administración Pública. Revista Trimestral de Direito Público - RTDP. São Paulo: Malheiros, n. ${ }^{\circ}$ 47, 2004.

PAZZAGLINI, Marino. Princípios Constitucionais Reguladores da Administração Pública. São Paulo: Editora Atlas, 2000.

PEREIRA, Cesar A. Guimarães. Discricionariedade e Apreciações Técnicas da Administração. Revista de Direito Administrativo - RDA. Rio de Janeiro: Renovar, v. 231, 2003.

PEREIRA JUNIOR, Jessé Torres. Controle Judicial da Administração Pública: Da Legalidade Estrita à Lógica do Razoável. Belo Horizonte: Fórum, 2ª ed., 2006.

PEREZ. Jesús Gonzáles. El Principio General de la Buena Fe en el Derecho Administrativo. Madri: Civitas, $3^{\text {a }}$ ed., 1999.

PICAZO, Luiz M ${ }^{\mathrm{a}}$ Diez. La Doctrina Del Precedente Administrativo. In: Revista de Administración Pública, v. 98, 1998.

QUEIRÓ, Afonso Rodrigues. A Teoria do "Desvio de Poder". In: Revista de Direito Administrativo - RDA. Rio de Janeiro: Renovar, v. 7, 1947.

. O Poder Discricionário da Administração. Coimbra: Coimbra Editora, 1944.

RAMOS, Elival da Silva. Ativismo Judicial: Parâmetros Dogmáticos. São Paulo: Saraiva, 2010 .

RAMIRES, Eduardo Augusto de Oliveira. Eduardo Augusto de Oliveira RAMIRES. Direito das Telecomunicações: A Regulação para a Competição. Belo Horizonte: Fórum. 2005. 
RAWLS, John. The Idea of Public Reason Revisited. The University of Chicago Law Review, v. 64, n. ${ }^{\circ}$ 3, 1997.

RE, Edward D. Stare Decisis. Tradução Ellen Gracie Northfleet. Revista Forense, v. 327, 1990.

RIVERO, Jean. Direito Administrativo. Coimbra: Almedina, 1981.

ROCHA. Cármem Lúcia Antunes. Princípios Constitucionais do Processo Administrativo no Direito Brasileiro. Revista Trimestral de Direito Administrativo - RTDP. São Paulo: Malheiros, v. 17, 1995.

RODRIGUES, José Ilceu Gonçalves. A Regra do Precedente na Common Law. Revista Jurídica Mineira. Belo Horizonte: Interlivros Jurídica, v. 101, 1993.

ROMANO, Santi. Corso di Diritto Amministrativo. Pádua: Casa Editrice Dott. Antonio Milani, CEDAM, 1937.

SAINZ MORENO, Fernando. Conceptos Jurídicos, Interpretación y Discricionalidad Administrativa. Madri: Civitas, 1976.

SÁNCHEZ MORÓN, Miguel. Discrecionalidad Administrativa y Control Judicial. Tecnos: Madri, 1994.

SARMENTO, Daniel. Supremacia do Interesse Público? As Colisões entre Direitos Fundamentais e Interesses da Coletividade. MARQUES NETO, Floriano de Azevedo; ARAGÃO, Alexandre Santos de. (Coords.) Direito Administrativo e seus Novos Paradigmas. Belo Horizonte: Fórum, 2008.

Interesses Públicos versus Interesses Privados na Perspectiva da Teoria e da Filosofia Constitucional. In: Interesses Públicos versus Interesses Privados: Desconstruindo o Princípio de Supremacia do Interesse Público. Rio de Janeiro: Lumem Juris, 2010.

SCHIER. Paulo Ricardo. Ensaio sobre a Supremacia do Interesse Público sobre o Privado e o Regime Jurídico dos Direito Fundamentais. In: Interesses Públicos versus Interesses Privados: Desconstruindo o Princípio de Supremacia do Interesse Público. Rio de Janeiro: Lumem Juris, 2010. 
SILVA, Clarissa Sampaio. Legalidade e Regulação. Belo Horizonte: Fórum, 2005.

SILVA, Almiro do Couto e. Poder Discricionário no Direito Administrativo Brasileiro. Revista de Direito Administrativo - RDA. Rio de Janeiro: renovar, v.179. 1980.

O Princípio da Segurança Jurídica (Proteção à Confiança) no Direito Público Brasileiro e o Direito da Administração Pública de Anular seus Próprios Atos Administrativos: O Prazo Decadencial do art. 54 da Lei do Processo Administrativo da União (Lei n. ${ }^{\circ}$ 9.784/99). Revista de Direito Administrativo - RDA. Rio de janeiro: Renovar, v. 237, 2004.

SILVA, Luis Renato Pereira. A Regra do Precedente no Direito Inglês. Revista de Direito Civil. São Paulo: Dialética, v. 75, 1996.

SILVA, Vasco Manoel Páscoa Dias Pereira da. Em Busca do Acto Administrativo Perdido, Coimbra, Almedina, 2003.

. Para um Contencioso Administrativo dos Particulares. Coimbra: Almedina, 2005.

SOUTO, Marcos Juruena Villela. Aspectos Jurídicos do Planejamento Econômico. Curitiba: Lumen Juris, 2003.

Função Regulatória. Revista Diálogo Jurídico. Salvador: Centro de Atualização Jurídica, n. ${ }^{\circ}$ 11, 2002. Disponível em www.direitopublico.com.br. Acesso em 08/09/2010.

SUNDFELD, Carlos Ari. Fundamentos de Direito Público. São Paulo: Malheiros, $5^{\text {a }}$ ed., 2010.

. O Direito Administrativo Ordenador. São Paulo: Malheiros, $1^{\mathrm{a}}$ ed., $3^{\mathrm{a}}$ tiragem, 2003.

O Direito Administrativo entre os Clips e os Negócios. Revista de Direito Público da Economia - RDPE. Belo Horizonte: Fórum, ano 5, n. ${ }^{\circ}$ 18, 2007.

- Introdução às Agências Reguladoras. In: Direito Administrativo Econômico. SUNDFELD, Carlos Ari (coord.) São Paulo: Malheiros. 2006. 
Processo Administrativo e Procedimento no Brasil. In: As Leis de Processo Administrativo. SUNDFELD, Carlos Ari e MUNÕZ, Guillermo Andrés (coords.). São Paulo: Malheiros, 2000.

; CÃMARA. Jacintho Arruda. Controle Judicial dos Atos Administrativos: As Questões Técnicas e os Limites da Tutela de Urgência. Revista de Direito Público - RDP. São Paulo: Malheiros, n. ${ }^{\circ}$ 16, 2002.

Motivação do Ato Administrativo como Garantia dos Administrados. Revista de Direito Público - RDP. São Paulo: Malheiros, v. 75, 1985

A Regulação das Telecomunicações: Papel Atual e Tendências Futuras. Revista Interesse Público, n. ${ }^{\circ}$ 10, 2001.

Para Entender o Direito Administrativo. In: Administração Pública: Coletânea. PETERS, B. Guy; JON, Pierre (Orgs.). São Paulo: UNESP e ENAP, 2010.

. Meu depoimento e avaliação sobre a Lei Geral de Telecomunicações. Revista de

Direito de Informática e Telecomunicações - RDIT. Belo Horizonte: Fórum, ano 2, n. ${ }^{\circ}$ 2, 2007.

TABORBA, Maren Guimarães. O Princípio da Transparência e o Aprofundamento dos Caracteres Fundamentais do Direito Administrativo. Revista de Direito Administrativo RDA. Rio de Janeiro: Renovar, v 230, 2002.

TÁCITO, Caio. Poder Vinculado e Poder Discricionário. In: Temas de Direito Público (Estudos e Pareceres). Rio de Janeiro: Renovar, v. 1, 1997.

- Vinculação e Discricionariedade Administrativa. Revista de Direito Administrativo - RDA. Rio de Janeiro: Renovar, 1996.

- Direito Administrativo Participativo. Revista Trimestral de Direito Público RTDP. São Paulo: Malheiros, v. 15, 1996.

. Direito Administrativo. São Paulo: Saraiva, 1975.

THOMAS, Robert. Legitimate Expectations and Proportionality in Administrative Law, Hart Publishing, Oregon: Oxford, 2000. 
TOURINHO, Rita. Discricionariedade Administrativa. Ação de Improbidade e Controle Principiológico. Curitiba: Juruá, 2a edição, 2009.

- A Discricionariedade Administrativa perante os Conceitos Jurídicos Indeterminados. Revista de Direito Administrativo - RDA. Rio de Janeiro: Renovar, v. $237,2004$.

VALDÍVIA, Diego Zegarra. Control judicial de la discrecionalidad administrativa: Viejo problema y nuevo excursus (sus alcances en la Doctrina Española). Revista de Derecho Administrativo. Circulo de Derecho Administrativo, 2005.

VALIM, Rafael. O Princípio da Segurança Jurídica no Direito Administrativo Brasileiro. São Paulo: Malheiros, 2010.

VERISSIMO, Marcos Paulo. Controle Judicial da Atividade Normativa das Agências de Regulação Brasileiras. In: O Poder Normativo das Agências Reguladoras. ARAGÃO, Alexandre Santos (coord.). Rio de Janeiro: Forense, 2006.

A Constituição de 1988, vinte anos depois: Suprema Corte e Ativismo Judicial à Brasileira. Revista de Direito. FGV, v. 4, 2008.

. Agências de Regulação e Democracia. Jornal Valor Econômico, 27/03/2003.

WIMMER, Miriam. Pluralismo jurídico e as transformações do Estado contemporâneo. Revista de Direito Público da Economia - RDPE. Belo Horizonte: Fórum, ano 5, n. ${ }^{\circ} 20$, 2007.

ZAGO, Livia Maria. O Princípio da Impessoalidade. Rio de Janeiro: Renovar, 2001.

ZANOBINI, Guido. Corso de Diritto Amministrativo. Milão: Giuffrè., 1958, v.1.

YIN, Robert K. Case study research: design and methods. Chicago: Sage Publications, 1990. 
